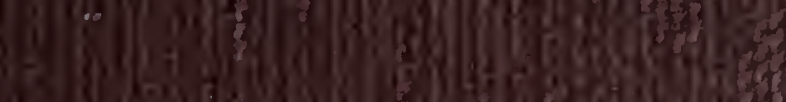
atot (2)

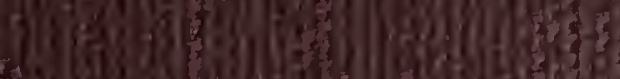

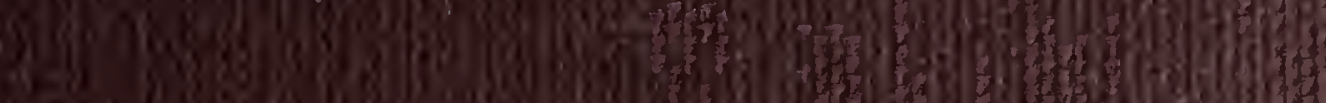
Dit) 55s I83 6 1.

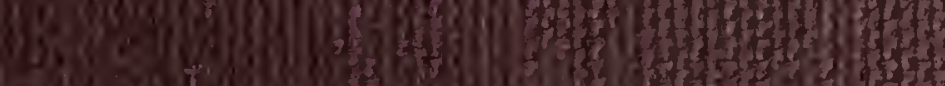

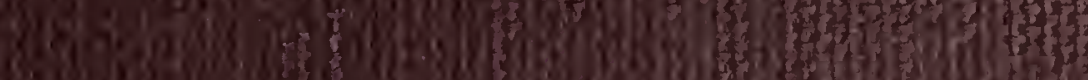

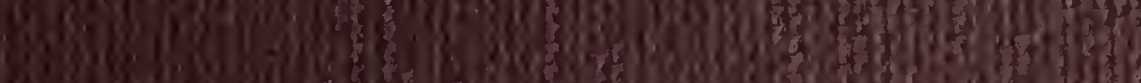

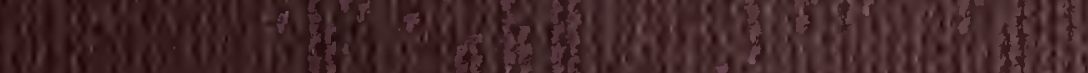
W(3) 4)

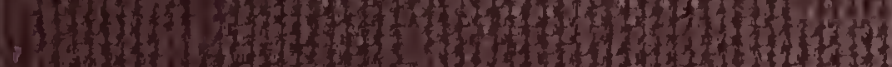
(1)

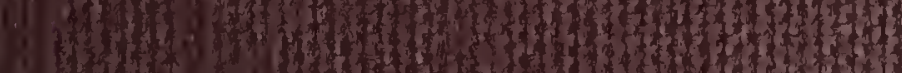
39.

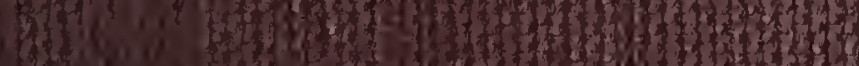
ato

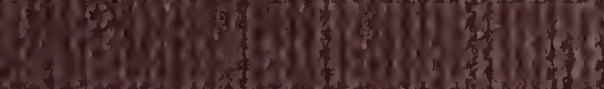

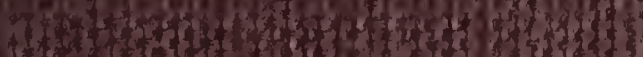
47. Wh

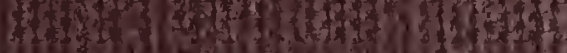
9.03 615 (1) A

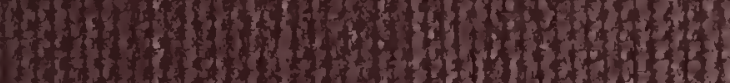

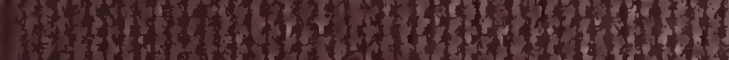
-19. Has?

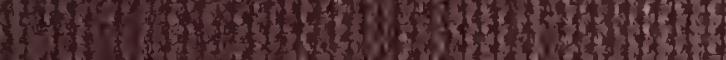

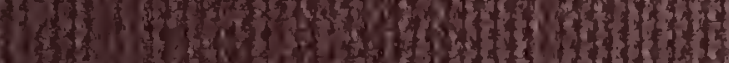

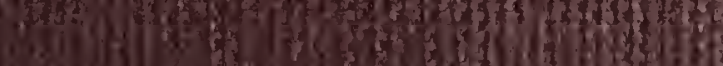
(12)

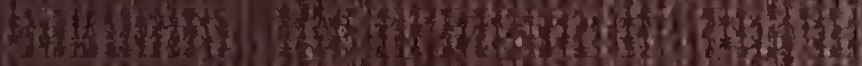

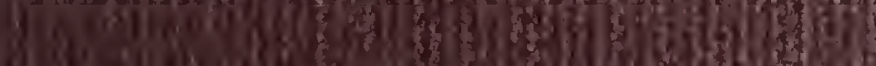

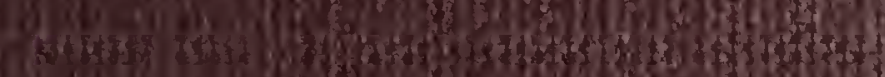

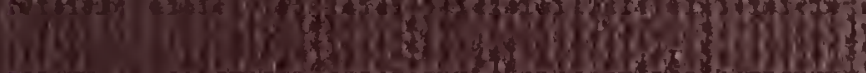

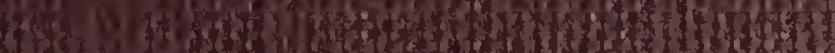

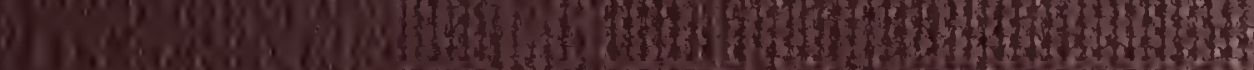

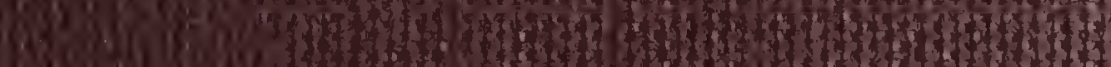

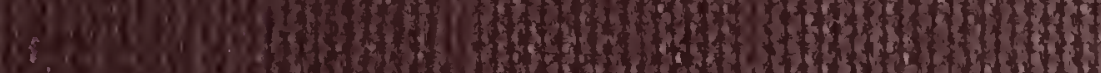
bin. 12. 20 .

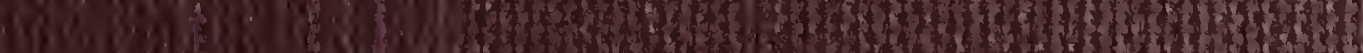

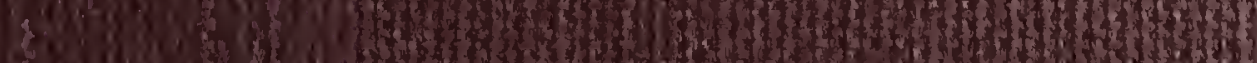

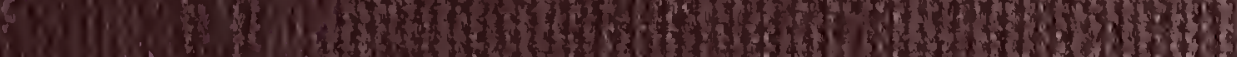

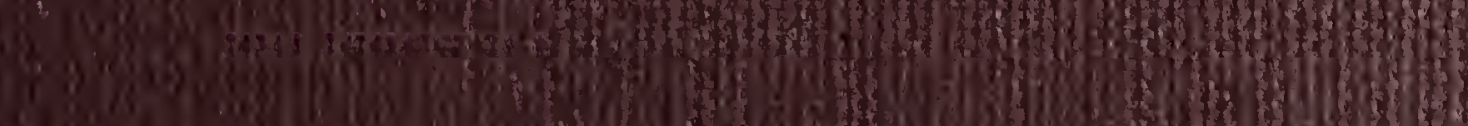

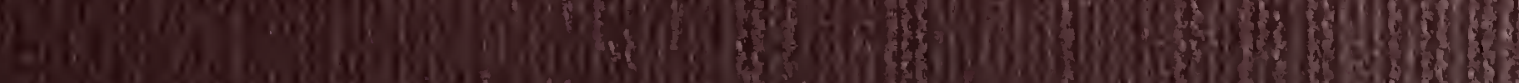

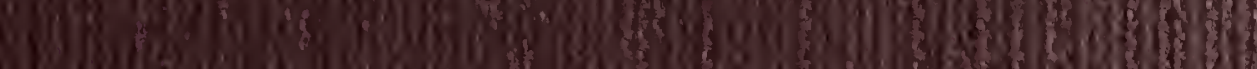
4. a n

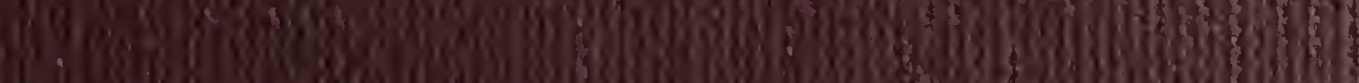
3.9. 


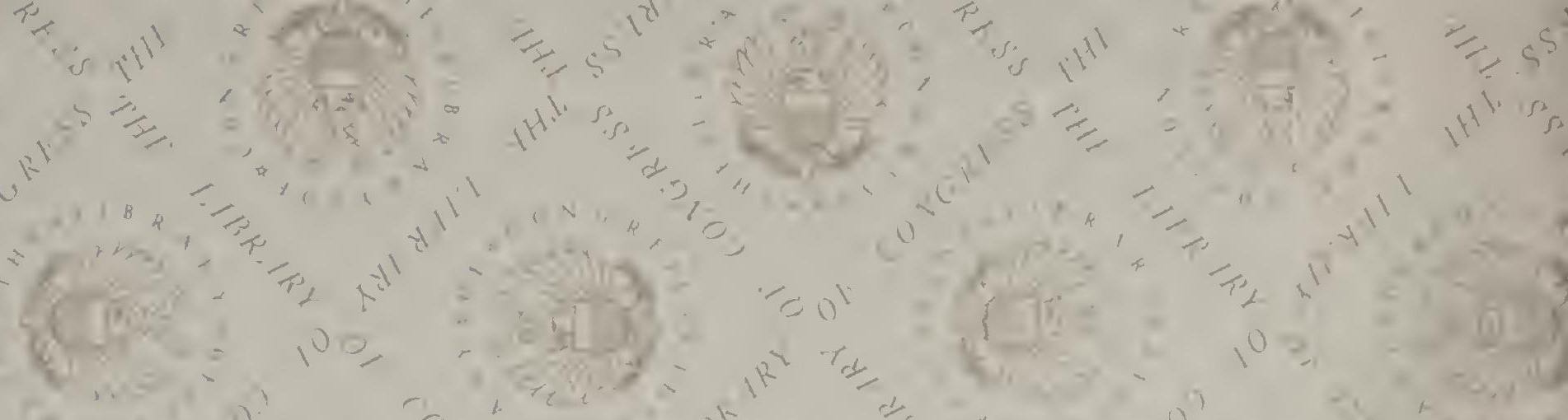
5

at

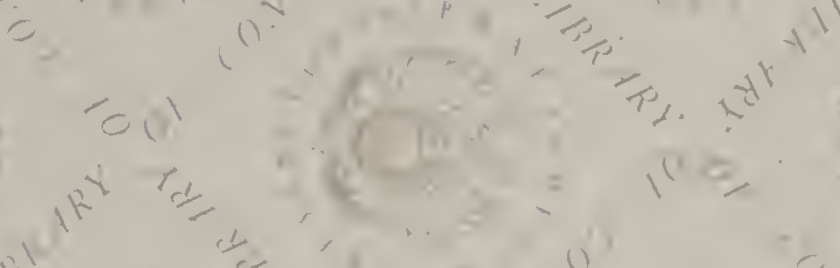

(6)

글

3

$\therefore x=4 x^{2}=1$

$\operatorname{lin}_{6} x$

$5^{5} \div$

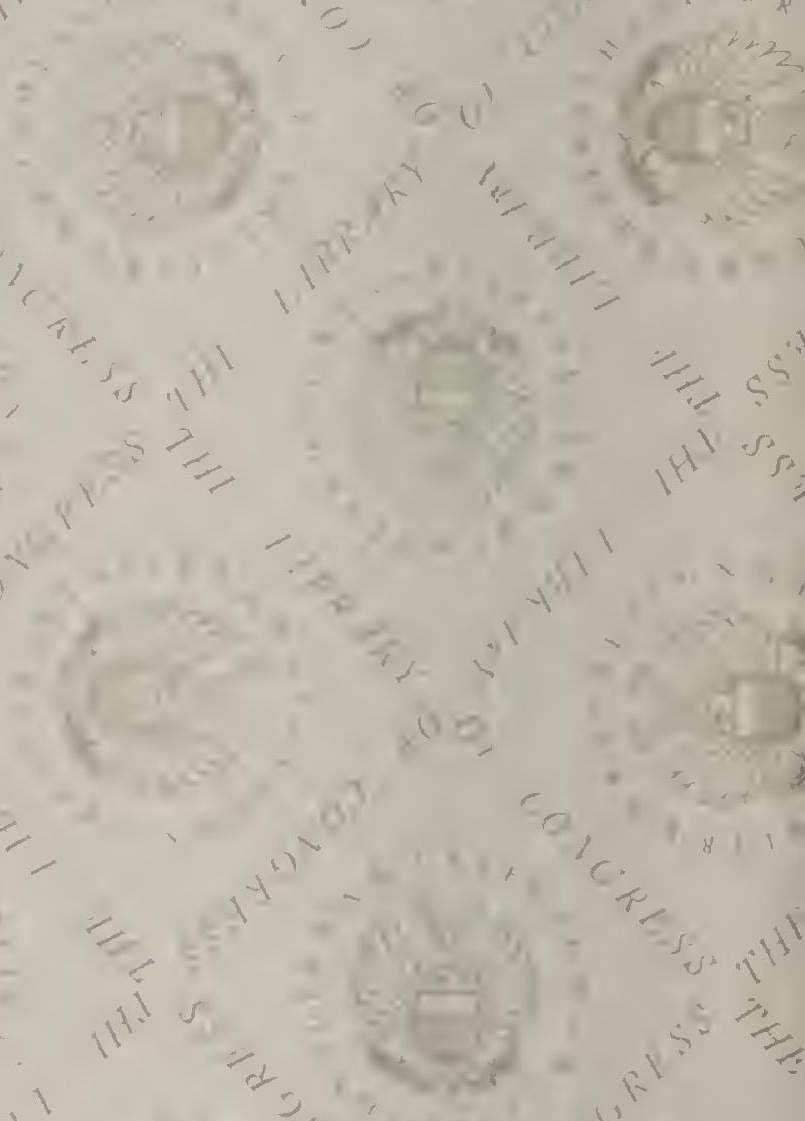

(fig:

s.

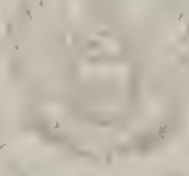

$4 x^{2} y^{2}=$

(i)

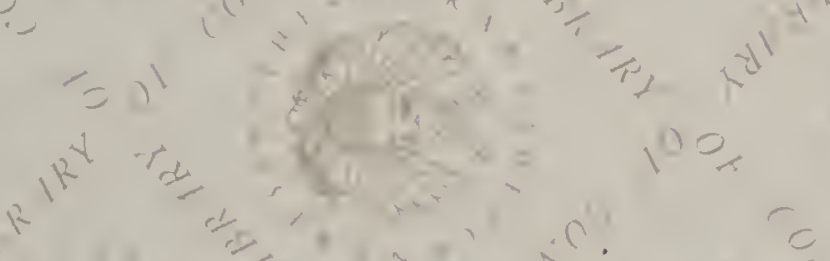

(n)

ten:

(3)

(a),

(on:

(n)
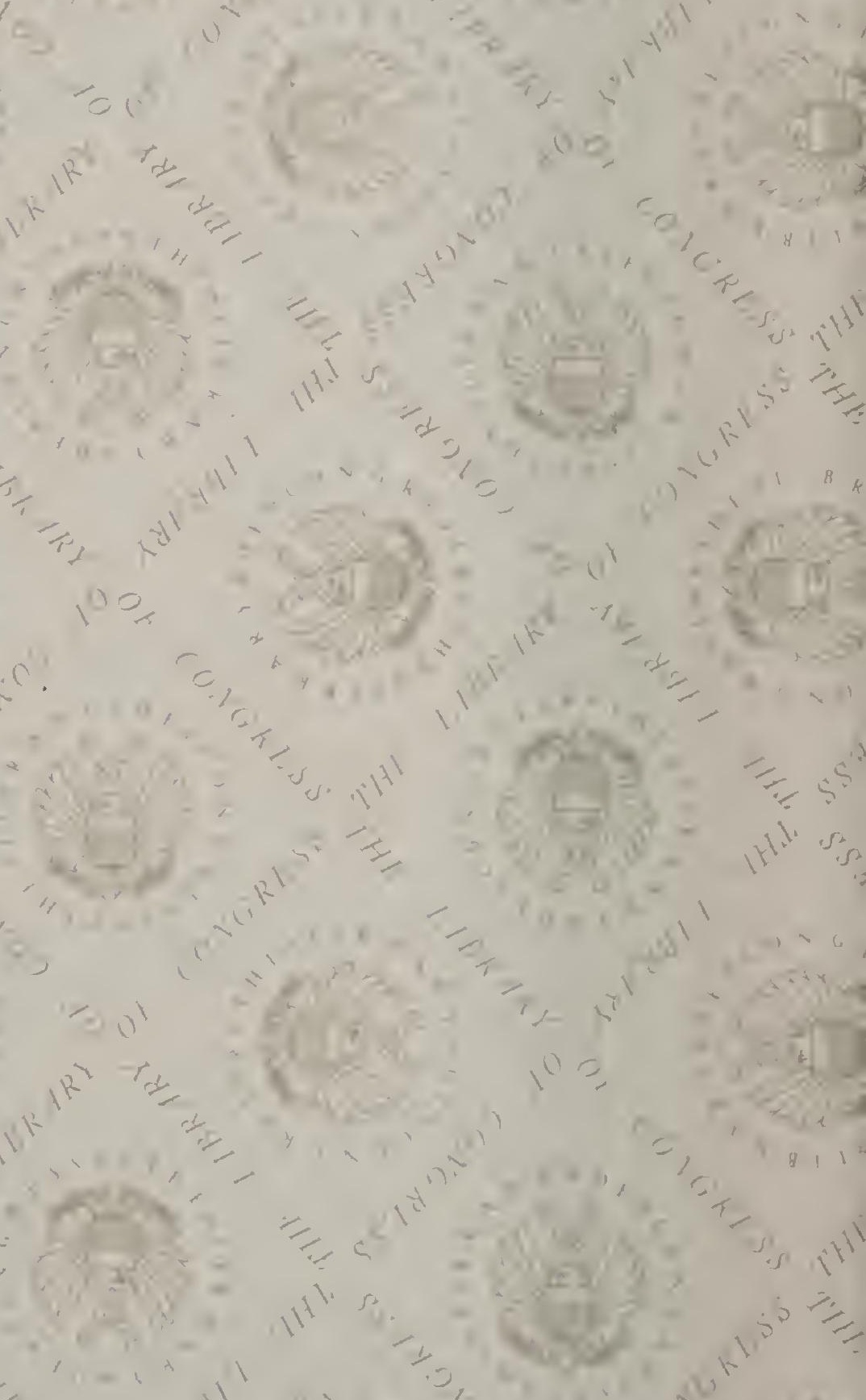

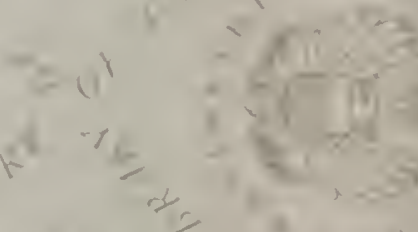

$\left.x^{2} \sin ^{2}\right)^{2}$

6. Lㄷㄴ

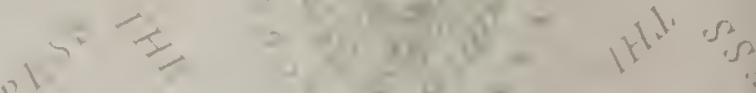

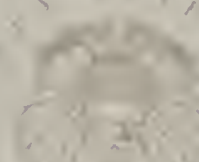






\section{COLOURED ILLUSTRATIONS}

OF THE

EGGS OF BRITISH BIRDS.

VOL I. 
"Some to the holly hedge

Nestling repair, and to the thicket some:

Some to the rude protection of the thorn

Commit their feeble offspring: the cleft tree

Offers its kind concealment to a few,

Their food its insects and its moss their nests.

Others apart, far in the grassy dale

Or rough'ning waste, their liumble texture weave,

But most in woodland solitudes delight;

In unfrequented glooms or shaggy banks

Steep and divided by a babbling brook." 


\section{COLOURED ILLUSTRATIONS}

OF THE

\section{EGGS OF BRITISH BIRDS,}

WITH DESCRIPTIONS OF

THEIR NESTS AND NIDIFICATION.

WILLIAM C? HEWITSON.

THIRD EDITION.

IN TWO VOLUMES.

VOL. I.

LONDON:

JOHN VAN VOORST, PATERNOSTER ROW.

M.DCCC.LVI. 


$$
Q^{2} v^{10^{5}} y^{60}
$$

$$
\begin{array}{r}
150608 \\
10
\end{array}
$$

LONDON :

Printed by H. W. Hutchings, 63, Snow Hill. 


\section{N TRODUCTION.}

An anxious wish to add a portion, however humble, towards the illustration of those glorious works from which I have myself derived such abundant pleasure, together with a desire to impart to others a portion of such pleasure, led to the production of the present work; and however deficient in its accomplishment, should it be the means of turning the attention of any to the pursuit of Natural History, my object will have been fully gained, and I shall have the happiness of knowing, that I have been partly the means of adding many a bright hour to their lives; feeling, as I do, firmly convinced, that next to those pleasures to be derived from the discharge of more important duties, there is no pursuit so calculated to impart the purest sensations of delight, and at the same time to elevate the mind; there is not a pursuit which diffuses the same serenity over the feelings, which soothes us in the hour of trouble, and which, when other pleasures flit away, continues to afford such undiminished enjoyment to the last. For my own part, that taste for Natural History which I have enjoyer from the earliest recollection, and which I regard as one of the choicest gifts of Providence, has proved to me an inestimable blessing. To its influence I owe all the brighter hours of my life; whether, in the full enjoyment of health and happiness, I have trod the green fields, in the joyous spring, delighted with the early flowers and the first song of the Sky Lark; or have wandered as a school-boy through the woods, "to pull the flower so gay ;" or in the autumn of the year have traversed the heathery mountains, when purpled o'er with blossoms, to watch the flight of the moor bird, and listen to the busy hum 
of a thousand bees; that taste has brightened every beautiful object in nature, and added a zest to every pleasure.

It is with a satisfaction unalloyed by any umpleasant feelings, that the lover of nature looks back upon and retraces in his memory the many happy hours which he has spent in the pursuit of his favourite object. Never shall I forget the first dawning of a love for nature upon my mind, as its various beautiful objects came crowding upon my notice-"wonders yet to me;" nor that strange feeling of delight which I have experienced from the capture of some long-chased butterfly, or the discovery of the nest of some then unknown bird.

However unimportant in itself the branch of Natural History which I have attempted to elucidate, the beautiful and varied objects which compose it, are amongst the first to excite the imagination, and call forth in boyhood those feelings, that love for nature, which are inherent in us all; and however the cares or the pleasures of after life may have erased those earlier feelings, there are few who have not one day derived pleasurable emotions from their contemplation, and who do not renember those joyous times when, at the first breaking loose from school, they have hastened to the wood and the hedgerow, in search of their painted prize.

Few can have failed to notice that wonderful and all-absorbing feeling of anxiety, that utter disregard of self, which, during the breeding season, produces so remarkable a change in the nature of many of our birds: converting that wariness for which they are at other times remarkable, into the most heedless disregard of danger.

Numerous anecdotes are related of the devotedness of the Partridge, and other species of birds, in the protection of their young.

The Misletoe Thrush, usually so shy, seeks the immediate neighbourhood of our houses during the season of incubation, rears its young ones within sight of our windows, and spreads terror amongst the rest of the featbered race by its pugnacious persecution of all intruders. 
I have elsewhere noticed the assiduity with which the Eider Duck covers its eggis.

Many of the smaller birds will allow themselves to be taken in the hand, rather than leave their nests. Some have been even known, upon having their young ones taken from them, to follow them into captivity.

The obstinate perseverance with which the Blue Titmouse continues to rebuild its nest, although it has been repeatedly destroyed, is very remarkable; and still more so the pertinacity with which it continues to sit its eggs, in defiance of all intrusion ; and to retain possession of the hole in which they were placed, sometimes for days after they have been taken from it.

Notwithstanding the numerous accornts we hear of the fecundity of some of our smaller birds, I am much inclined to think that their powers of incubation have been overrated, and that the usual number of eggs only, which it is allotted them to lay, are sufficiently developed to be brought to maturity at one time. Those birds, however, which under ordinary circumstances would only breed once a year, have nevertheless, if deprived of their eggs, the power of producing, a short time afterwards, a second and even a third set; but usually diminished in their numbers, as well as in their size.

That the colouring of birds' eggi is an animal matter, and dependent upon the health of the bird, there can be little doubt. The day previous to the eggs being produced, and after the shell has become hard, they are, in those birds which I have examined, pure white; a large proportion of the colour is also easily rubbed off, for some time after they have been laid. Thus we find in their eggs the same want of colour, which is also occasionally observable in the feathers of white varieties of birds. Fear, or any thing which may affect the animal functions, exerts its influence upon the colour also. The eggs of birds which I have captured on their nests, during the time that they were laying, and kept in close confinement, have thus been deprived of much of their colour. 
That the varied and beautiful hues which adorn the eggs of birds, are given them by the God of nature, as a protection from discovery and destruction, by resembling the various surfaces upon which they are deposited (as stated by M. Gloger, a German naturalist), when taken as a general rule, I am by no means ready to admit. On the other hand, I am prepared to show, that such precautions would be for the most part unnecessary and superfluous.

By far the most numerous class of birds are those which build in trees or bushes, and at an elevation from the ground; and the nest-which then forms the object of search and detection-being once discovered, further precaution to conceal the eggs would be of no avail; and on this account we find such an instinctive anxiety amongst the feathered race to conceal and protect the homes of their future offspring. I could quote a number of instances, any of which are sufficient to excite our wonder and admiration. Who has ever discovered the nest of the Common Wren, concealed and buried as it is amongst the same material of which it is itself constructed, without a feeling of pleasure and surprise? I have frequently seen it let into the hollow of some moss-clad stump, or so nicely woven into the side of a clover stack, when, had it not been for the small round hole of entrance, discovery would have been perfectly evaded.

The nest of the Chaffinch is little less wortlyy of remark; built upon the branch of some tree clothed with lichens, it is covered with the same material. Those birds which, from the large size of their nests, are prevented from thus concealing them, have recourse to other means of protection. The Hawk, the Crow, and the Magpie, place theirs in places difficult of access ; the nest of the latter being defended besides by a roof of thorns, which is not easily penetrated.

That there are several instances in which the eggs of birds are admirably adajted to, and closely resemble in colour, the ground upon which they are deposited, I have frequently found, much to my annoyance, when in search of them; and these are 
just the instances where such protection is most necessary, and where contrasting colour's would lead to their detection; such is the case amongst those birds which, making little or no nest, deposit their eggs, for the most part, upon the bare ground, or the shingle of the sea beach, and leave them uncovered on the least alarm. Of these are the Ring Dotterel, Oyster Catcher, the Sandpipers, Peewit, and the Terns, especially the Lesser. Amongst the other ground builder's, the safety of the eggs consists in the careful and constant assiduity with which they are covered by the female; and more so in the adaptation of the bird's feathers than its eggs, to the colour of the surrounding surface; as the dull and very similar colouring of the females of nearly all the Duck tribe, of the hen Pheasant, and the Grey Hen (Tetrao Tetrix), - so strongly as they are contrasted too with the brighter colour's of their mates, which do not assist in incubation, - will illustrate most admirably. Were I to mention those birds, the eggs of which do not bear any resemblance to the surface on which they are deposited, I should have to enumerate much the greater portion of our British Birds. Who will say that there is any resemblance whatever in colour, between the clear blue eggs of the Thrush, and the mud-lined interior of its nest? Neither do the bright blue eggs of the Hedge Sparrow bear much more resemblance to the nest. What likeness do the eggs of the Swans, the Geese, the Harriers, and the numerous species of Ducks (all white, or nearly so), bear to the ground upon which they are placed? and why, if their colours only are intended for their concealment, are eggs so entirely different in that respect, placed in situations perfectly alike?

It may be asked, for what purpose then are these beautiful colours lavisher so abundantly? For the same purpose for which they adorn the plumes of the humming-bird, or the wing of the resplendent butterfly-to gladilen our eyes, "To minister delight to man, to beantify the earth." And thus it is that the eggis of nearly all those birds (the Owls, Kingfisher, Bee-eater, Roller, Nuthatch, and the Woodpecker), which con- 
ceal them in holes, aro white, because in such situations colour would be displayed to no purpose.

The number of eggs laid by various tribes of birds, as well as by the different genera of the same family, vary much. The more typical species of these are, however, for the most part nearly alike in this respect. In every instance we shall find the same beneficent influence acting for our welfare; increasing rapidly those species which are of the greatest use to us, and bestowing upon those intended for our more immediate benefit, a most wonderful power of ovo-production; and at the same time curtailing in their numbers those species which, in their greater increase, would soon become injurious to us. Most of the Rasores, which, as game, form so agreeable an addition to our table, as well as the Duck tribe, lay numerous eggs. Some of the Warblers, and the various species of Titmice, which render us such essential service in the clestruction of the numerous insects which would otherwise become a nuisance, are unustally prolific.

In their relative sizes, the eggs of birds differ in a remarkable degree from each other, as I have shown, when clescribing those of the Guillemot; and this will be seen by comparing those of a few species. The Guillemot and the Raven are themselves of about equal size; their eggs vary as ten to one. The Snipe and the Blackbird differ but slightly in weight; their eggs remarkably. The egg of the Curlew is six or eight times as large as that of the Rook; the birds are of about the same size. The eggs of the Guillemot are as big as those of an Eagle; whilst those of the Snipe equal in size the eggs of the Partridge and the Pigeon. The four eggs of the Jack Snipe weigh nearly as much as the bird itself. The reason of this great disparity in size is, however, obvious; the eggs of all those birds which quit the nest soon after they are hatched, and which are consequently more fully developed at their birth, are very large, and yet so admirably formed to occupy the least possible space, that the Snipe has no more difficulty in covering its eggs, though apparently so disproportionate, than the Thrush or the Blackbird. 
As I have elsewhere remarked, much useful and highly interesting information might be gained towards the classification of birds, by paying some attention to their eggs; and it is very gratifying to find, in thus regarding them, that, with the exception of a few instances, were we to take the eggs of our British birds as our only guide, we should arrive at the best and most approved arrangement of the different genera. All those new genera which have been lately adopted, are clearly indicated in the difference of their eggs, and in none more than in those of the Snow Bunting and the Bearded Titmouse; the former of which was associated with the genus Emberiza, the latter with that of Parus; the very great similarity which the eggs of each of these genera (Emberiza and Parus) bear to each other, at once pointing out the intruders. I would not, however, have any one place too implicit reliance on the character of their eggs for the arrangement of the birds. There are puzzling instances in which, by so doing, we should be led into error, and be tempted to place apart from each other the eggs of the Pied and Spotted Flycatchers, the Common and Tythis Redstarts, and to separate those of the Common and Misletoe Thrush from the rest of the genus, the Swallow from the Martin and the Swift, the Little Bittern from the more common species, and the Woodcock from the Snipe; and placing too much reliance upon those minute differences which serve so beautifully to connect and represent neighbouring genera, we should be led into a similar mistake with regard to the eggs of the Pied Wagtail, the Grasshopper Warbler, the Wood Wren, and the Wheatear.

The generic characters of eggs are in some cases as distinctly marked in contour and in colour as are the birds themselves. Any one would immediately recognize the close affinity which those of the different species of Crows bear to each other, as also those of the Owls, the Ducks, the Divers, the Buntings, the Titmice, the Sea Gulls, and the Terns, greatly as the latter differ individually. In shape, the eggs of the Grebes are very peculiar, as are those of the more typical waders. This affinity 
is not confined to genera only, but may be traced, more or less, in most of the families, and is very remarkable throughout the Scolopacidæ, the eggs of which are much pointed at the smaller end, and almost invariably four in number.

There is too, in many genera, a beautiful analogical resemblance with others nearly allied to them. The Eagles and Hawk tribe (nearly all of which breed aloft) approach by the genus Circus, which breeds upon the ground and lays eggs which are white or nearly so, that section of the Ow]s which is the most Hawk-like, the species of which also, departing from the habits of the rest of their family, breed upon the ground. The eggs of the following genera, Corvus, Fregilus, Pica, and Garrulus, are all closely allied, as are those of the Roller, Merops, and Alcedo.

Eggs are subject to much variety, and are not without those apparent discrepancies which beset the study of other branches of Natural History, and which are only to be reconciled by oft-repeated observation, and by combining with their study a knowledge of the nests in which they are found. And thus, as regards the different species of a genus: although the eggs of some of the Thrushes usually bear but slight resemblance to each other in colour, we shall find upon a closer acquaintance with them, that there are other connecting links. The nests of all the species are much alike, each being strongly cemented with clay; and much as the eggs of the Common 'Thrush and the Blackbird appear to differ at first sight, they nevertheless run imperceptibly into each other, in some of their varieties. I have seen eggs of hoth species, of a clear spotless blue. My friend, Mr. Henry Doubleday, one year found several nests of the Blackbird, at Epping, in one locality, the eggs of which were all of this description; a variety perpetuated, probably, through the several individuals of the same family. Eggs of the Wheatear are occasionally spotted like those of the allied species, and eggs of the Spotted Flycatcher, as well as those of the Pied, are sometimes of a uniform unspotted blue. No one who has seen the nests of the Swallow and the House Martin 
(resembling each other as much as they difler from those of all other genera), will need to be told that they are closely allicd, much as the eggs differ in colour.

With regard to birds of the same species, although the eggs of most of them are subject to more or less variety, some are constant, or nearly so, in their colouring, whilst others display an almost unceasing variety. Amongst the former, are those chiefly of one colour, to which may be added a few others, which seldom vary much. These are the Golden Oriole, Lesser Whitethroat, the various species of Titmice, Reed Bunting; Goldfinch, and Black Grouse. The eggs, on the other hand, which are subject to the greatest variety, are those of the Water Birds, the Gulls, Terns, Guillemots, dc. ; and of the land birds, the Red Grouse, the Rook and Carrion Crow, Yellow Bunting, and House Sparrow, and above all, the Tree Pipit. There is, notwithstanding, in all these a character, by which a little cxperience will for the most part enable us to determine the species; and though we might not readily believe the varieties of the eggs of the Tree Pipit to belong to the same species, we should have no difficulty in refcrring them to the right genus.

In other branches of Natural History the larger the series of specimens we have for comparison the more likely we are to arrive at a correct conclusion as to species. In Oology it is otherwise. The more we see of the eggs of the Waders and Water birds the more difficult it becomes to point out with certainty the demarcation of species, or to fix upon those which are the most typical. Colour and form alone are but unsafe guides.

In places where those materials are to be met with which instinct has taught individuals of the same spccies of bird to make use of in the construction of their nests, we shall usually find the same adopted. I know of no other bird which seems so much to consult its own taste in this respect, as the Common Wren. The materials of its nest are as different as the situations in which it is placed. It may be found built entirely of clover, even in places where moss is abundant; its interior is 
also formed according to the taste of the owner, and is as often found without any lining at all, as it is thickly lined with feathers.

There are many instances in which circumstances have led to a deviation from the usual habit. Those Eagles and Hooded Crows inhabiting the Shetland 1slands, which would build their nests of sticks, were such materials to be liad, are there compelled to substitute the larger species of sea-weed. A Carrion Crow which resorted to the Fern Islands to breed, for the same reason (the absence of sticks), made its nest in a hole in the ground, surrounding it, to give it sufficient depth, with a wall of sods.

There are a few deviations from the usual instinct, which, not being influenced by local causes, are very remarkable; and in 110 instance which has come under my notice, more so than in the nest of a Blackbird, sent me by my friend, the Rev. W. D. Fox, which is lined with black hair, instead of the usual material, dry grass; the same circumstance liaving occurred several years in succession.

With regard to the situation of their nests, birds seem to be left much more to the influence of their own choice, constructing them with surprising skill, in places apparently most unsuitable. Some species, leaving their natural mode of life, and their own wild haunts, have adapted their habits to our own, and being to a certain extent domesticated, have become our confiding friends and delightful companions. The Swift, the Martin, and the Swallow, once the inlabitants of the inland rocks and lonely sea cliffs of our coast, have now become the voluntary inmates of our dwellings, cheering us with their cheerful notes and elegant evolutions. The shy Hawk, the wily Raven, and the midnight Owl, leaving their native woods, have built their nests in the towers and steeples of our towns and cities. The Magpies, too, which with us are so suspicious of wrong, build their nests under the eaves of the Norwegian cottages. Numerous instances might be given, in which birds have chosen the most strange and singular situations for their 
nests, adapting them as though reason had been their guide. The most remarkable on record is that of the Rooks, which for ten successive years, built their nest upon the vane at the top of the Newcastle Exchange, revolving with every change of wind. The House Sparrow, the nest of which, when built in trees, is large and carefully arched over, dispenses with the labour of constructing its own roof; when it places it under the eaves of our dwellings.

In coming to the conclusion of this, the Third Edition of our British birds' eggs, it is natural to revert to the time-some twenty-five years ago-when the earliest pages of the Oology first saw the light, and to note with pleasure the great progress which has been made during that period towards a knowledge of the subject. The book ("the Oology") was itself as migratory as the birds, the eggs of which are depicted in its pages; many of the plates were drawn at night after a long day of railway surveying in the fields, and the letter-press was printed wherever the author happened to be stationed at the time. There were few collectors to aid him in those days; and it is with a grateful feeling he remembers now the helping hand which was then held out to him by his friend, Mr. Yarrell.

Many eggs, which are now to be had in profusion, were then scarcely known; and a large number, which in my most hopeful hours I never expected to see, have been figured in the succeeding editions of the work. So little was known as to our British birds' eggs at the commencement of the "Oology," that its plates were published unarranged, so as to receive new materials during its progress, and it was with feelings of delight which leave a bright memory behind them, that the kindness and liberality of correspondents, such as Mr. Spurgeon and Mr. Dashwood, enabled me to add one beautiful thing after another to the list, until the extended researches of Mr. Salmon, in Orkney; Mr. Atkinson and Mr. Procter, in Iceland; my own bird- 
nesting excursion in Shetland and in Norway with Mr. John Hancock, and Mr. Hoys' successes in the Low Countries of the Continent, nearly doubled our previous knowledge ere the close of the book.

Since then collectors of birds' eggs have become numerous. Oology has become a fashionable pursuit; dishonest dealers have largely profited by the demand; plaster casts of a rare egg have been sold as the originals; and with the exception of some of the best, there are few collections in which comnterfeit eggs do not abound.

It has been my anxious wish to figure eggs only which those most conversant with the subject believe to be truly authentic. In the present edition the eggs of five species figured in the last (as to which there are some doubts), have been omitted, twenty-five new species have been added; and those who are credulous enongh to be satisfied with them, will find representations of many more in a book of which the Rev. Orpen Morris is the editor.

Most of that which is new and of value in the present edition has been supplied by the perseverance and enthusiasm of Mr. Wolley. To him, to Mr. Bond, Mr. Hancock, Mr. Newton, Mr. Salmon, Mr. Walter, Mr. Wilmot, and Mr. Yarrell, I would offer my most earnest thanks. The kindness which I liave experienced from each and all of them is not to be forgotten.

The egg which is drawn at fig. ii. plate xxxii. is not that of the Reed Warbler, but of Salicaria palustris, a continental species.

It was sent me by mistake, but will not inaptly represent some varieties which I have seen of eggs of our own British species. 


\section{PREFACE.}

I HAD never flattered myself with the slightest expectation that a Third Edition of the work on Birds' Eggs would be required, and regret that I have not accumulated - during the sale of the second edition - those materials, which I otherwise might have done, to render it more worthy of the approbation of the public.

Greatly encouraged by the success of the past, and the very kind and liberal offers of assistance which I have met with for the present and the future, no pains shall be spared on my part to make the illustrations of the forthcoming work as perfect as possible.

When the former edition of the Lggs was published, it was my wish that it should be as much as possible a sequel to the British Birds of Mr. Yarrell, and in bringing out another edition of the work-and for the same reasonI am induced to figure the eggs of those species of birds which have since been added to his work, not because I think them in all cases well entitled to a place amongst our British birds, but because he has thought so.

It is a difficult thing in these days of rapid transit to draw a line which shall mark the boundary of a truly 
British bird. Resting on the rigging, many a bird might cross the ocean with a steamboat from the New World to the Old.

I would not hesitate to admit as British, after one well authenticated visit, a bird of Europe, or of those countries at no great distance from us and closely bordering upon the European continent; but, until there is a wellattested fact that a land bird can cross on wing some thousand miles of sea, I would rigidly exclude all birds which are exclusirely Asiatic or Australian or American, and would either doubt the authority which told me that they had been seen alive and at large in Britain, or feel perfectly convinced that they had escaped from confinement.

Oatlands, Walton-on-Thames, April, 1853. 


\section{EGGS OF BRITISH BIRDS.}

RAPTORES.

VULTURIDAE.

\section{GRIFFON VULTURE.}

Vultur Fulves.

PLATE I.

THE occurrence of a solitary specimen of this bird in Ireland was communicated to Mr. Yarrell, who has figured it in a Supplement to his "British Birds." Of its habits during the breeding season we have the best account from the pen of Le Vaillant, who, when describing another species of Vulture which he calls l'Oricou, tells us that the same description is equally applicable to the Griffon Vulture, which he names Chasse-fiente, and which he says is much the more numerous of the two, although they both lay the same number of eggs, two, for the most part, but sometimes, though rarely, three; that they resort, in the breeding season, in great numbers together, to rocks in the most elevated situations, and that a single precipice will contain as many nests as there are convenient places to receive them; that the birds live very amicably together, and that he has seen three nests placed side by side in the same care; that during the time of incubation the male bird stands sentinel at the mouth of the hole, thus pointing out the position of its nest, but that it is almost always inaccessible. He says, 
that he has, nevertheless, often risked his life to examine the eggs and young birds, and with the aid of his Hottentots has sometimes orercome all the difficulties, although the approach to their retreat is so slippery as greatly to increase the danger, and the den itself indescribably disgusting. Le Vaillant says, that the Griffon Vultures are more conspicuous than the l'Oricou, and are very easily seen upon the rocks at the entrance of their holes, and that it is a pretty sight to watch a troop of them covering a whole chain of mountains and to see them, on the report of a gun, heavily take flight together and rise in circles in the air. He says that the eggs are bluish white, that he has often eaten them, and found them tolerably good. The egg from which my figure is taken was laid at Knowsley, and presented to Mr. Wolley, who has kindly trusted it to my care. Others have been laid at the Jardin des Plantes in Paris.

Mr. Yarrell says, that " in Sardinia, and some other countries, this Vulture makes a large nest of three or four feet in diameter on high trees, and lays two, or sometimes three, elongated white eggs." 


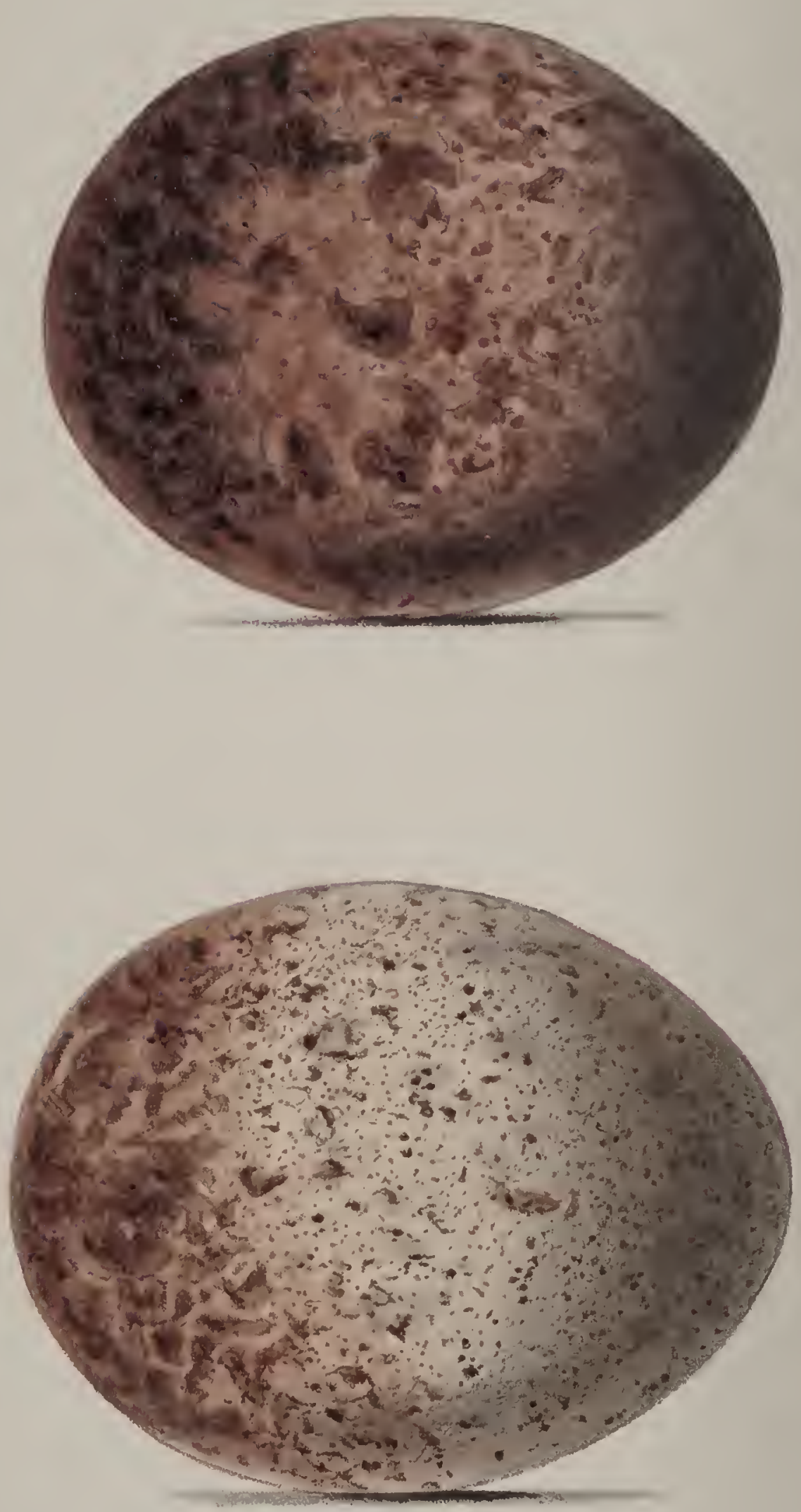


\section{EGYPTIAN VULTURE.}

\section{Vultur Perchopterus.}

PLATE II.

VERY little information is to be had in the works of the Continental naturalists with regard to the habits and propagation of this species. Temminck says that they are numerous on the Spanish side of the Pyrenees, but nowhere so abundant as in Africa, and that they breed in those precipices which are the most difficult of access. M. A. Moquin Tandon, of the Jardin des Plantes at 'Toulouse, who has kindly sent me a drawing of an egg of this species which is in his own collection and resembles the second figure of the plate, tells me that in 1842 two nests of the Vultur percnopterus were discovered in the vicinity of Arles on the Pyrenees each of which contained two eggs; and that the following summer a third nest was found on the Pic de St. Loup, near Montpelier, which had in it but one egg.

Mr. Wolley obtained eggs of this species (from one of which the figure in my former edition was taken), during a visit to Tangier, from a dealer of the name of Favier, who assured him that the old bird had been shot from the nest in which was one of them. Mr. Wolley has sent me the following:- "I was informed by $M$. Favier that the Vultur percnoplerus makes its nest at the end of March in the crevices and caves of rocks, 
usually in places inaccessible and in a perpendicular cliff; that it lays in the month of April one or two eggs, which are hatched about the end of May; and that the young ones remain in the nest till July, before which they are incapable of flight; that of four sets of eggs taken in Western Barbary, there were two pairs and two single ones."

This confirms the account sent me by M. Tandon.

The Egyptian Vulture is nowhere so frequent as in Egypt, and particularly about Cairo, where it was a very great breach of order, at the time Bruce wrote, to kill one. In this and other towns it occupies the roofs of houses, in company with black kites, hawks, crows and turtle doves; all forming, says Sonnini, a distinct population, not less numerous, but more peaceable than that below.

Bruce thinks that the Arab name Rachama, still applied to this bird, does not allow us to doubt that it was the emblem of parental affection, which is frequently mistranslated Eagle in our Bible.

In South Africa Le Vaillant found a pair attached to most of the dwellings of the natives, generally seated upon the fences with which they inclose their cattle, where they are not only uninjured by the orners, but are also objects of pleasure to them, eating greedily even what they refuse.

They are occasionally collected in numbers round their food like the larger Vultures, and Sonnini states that during the French occupation of Egypt, the first sound of the cannon brought these and other birds of similar tastes from every direction to the summons.

The eggs of this species differ considerably in form and colour; whilst some have the usual contour, as in the second figure of the plate, others are widest exactly in 
the middle, and taper to each end. Besides the two varieties figured, Mr. Wolley's collection contains a third, which differs very little from eggs of the osprey. To the liberality of $\mathrm{Mr}$. Walter-in whose fine collection they are-I am indebted for the use of the eggs figured. 


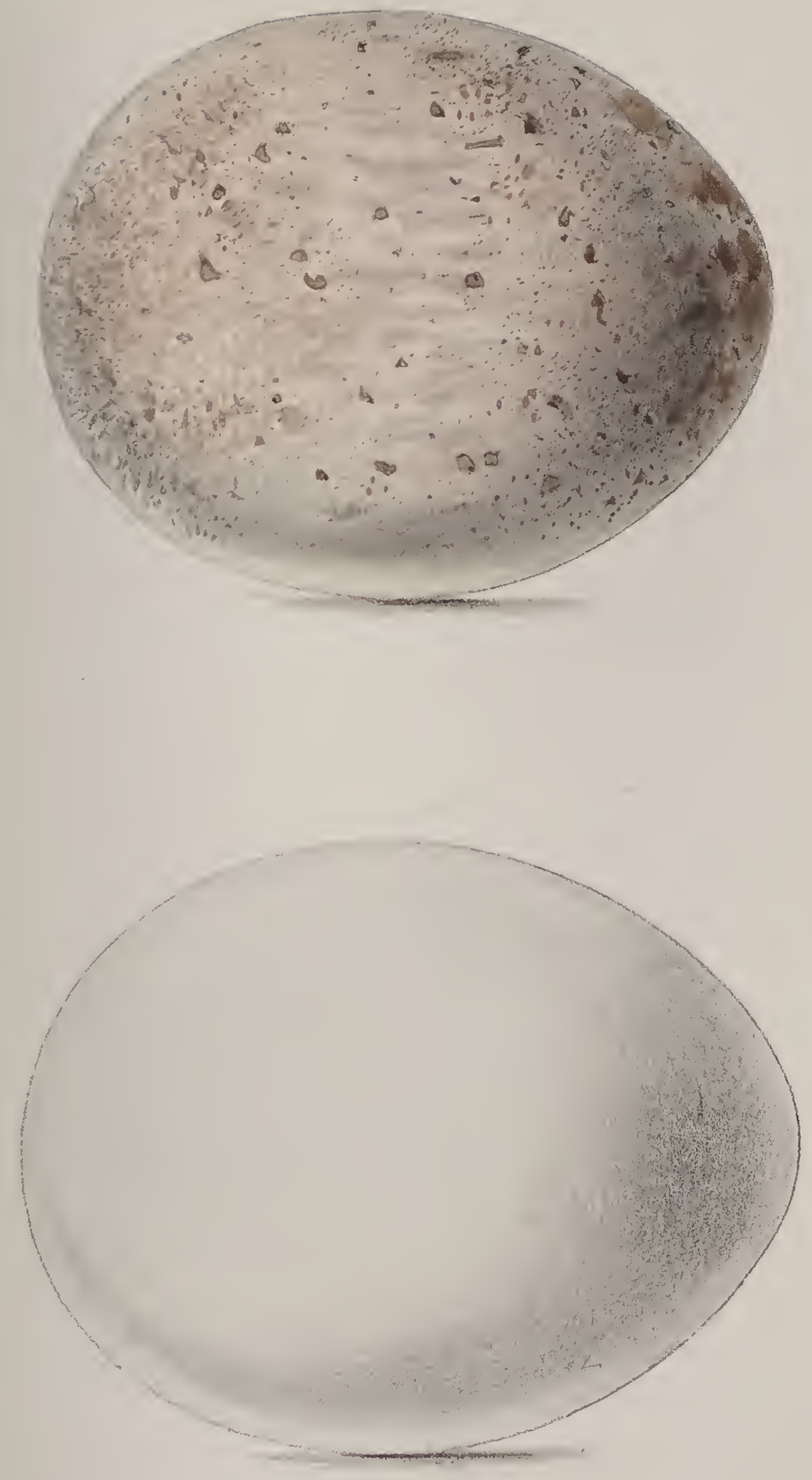

nest. This was high up the face of a precipice, the only access to which was through a deep and rugged gully on the right. We succeeded, after a most toilsome scramble, in reaching a sloping ledge of rocks, which we supposed must be above the nest. We had laid down our guns, that we might hold on by the scanty tufts of grass which grew from the crevices of the rock, when the eagle rose within gunshot of our position, discorering to us its nest, a young one, and an unhatched egg. The nest was placed in a hollow of the rock, and was composed of a large mass of sticks, and appeared to be thickly lined with soft materials. Between us and it intervened a large cubic mass of rock, so steep on its sides as to prevent the chance of our reaching the nest without the help of ropes. It went sadly against our inclination to retreat; it wanted, however, but a few hours of the time when we must commence our homeward voyage.

In Norway, where they enjoy an uninterrupted sway, and can choose their nesting-places undisturbed amongst those magnificent rocks which bound its glorious fiords, we saw them often perched upon the centre of some lonely island, where they would remain seated motionless for hours together. At midnight, whilst tranquilly gliding over those calm inland seas, we have sometimes disturbed one when thus seated. Its motion is then slow, heavy, and like a Heron, till, rising high in air, it assumes its own majestic flight.

Upon the pinnacle of a steep and rocky island, to which we had climbed to watch the midnight sun, we found that we had seated ourselves upon the oft-frequented resting-place of the Golden Eagle. The rock was strewed with feathers and the remains of many a meal.

Birds of the same species, with one or two exceptions, 
of which the Common Wren is the most remarkable, will almost invariably, when under favourable circumstances, form their nests of the same materials.

In Shetland, where they would have some difficulty to find a stick, the eagles have very cleverly constructed their nests of those long rope-like pieces of sea-weed, which, having their roots at the bottom of the ocean, rise like mimic forests to its surface, and spread out their long riband leaves. These in their pliability are so admirably adapted for the purpose, that I much doubt whether a Shetland eagle, with the choice of both, would ever have recourse to the more commonly used material.

Foula, one of the Shetland Islands, the western boundary of which is formed by one of the grandest promontories in Britain, is the favourite resort of the Golden Eagle.

It begins to breed in March, or early in April, and will return to the same eyrie for many successive years. It makes a nest of great size, composed of sticks (in Shetland of sea-weed), lined with softer materials, roots, dry grass, and heather. The eggs are usually confined to two, though sometimes three in number. Mr. Wolley had three fertile eggs from one nest, whilst one mentioned by Mr. Salmon, in his bird-nesting account of Orkney, contained three young ones.

The most ardent lover of bird-nesting must give place to him who has become as familiar with the king of birds as others are with crows and magpies. To him I am indebted for the following valuable notes, a short extract from many pages of interesting matter, which my space will not allow me to quote entire. Mr. Wolley, speaking of the Golden Eagle, says, "In different years I have carefully examined eight or nine distinct eyries of this bird in Scotland, and visited the sites of many more; 
they have always been in mountainous districts, but only in one instance at any considerable elevation, and there it was a little cave or cell which appears to have offered advantages too great to be neglected. In every other case they have been upon a ledge or step, with rock rising quite close behind them, and often overhanging the nest so as to shelter it more or less. There is frequently a projecting shoulder at one side, and in all that I have seen there has also been a face of rock below, sometimes dipping down close, but, in other situations, not till a distance of several yards from the outer edge of the nest; a man, upon whose word I can place implicit reliance, told me of an old nest which he also offered to show me, placed upon the ground at the foot of a rock rising out of a hill side, and near it, also upon the ground, the nest of a previous year.

"In the Orkney islands I was assured that an old woman had one season come unexpectedly upon the Golden Eagle's eyrie, and walked off with the eggs in her apron. Generally there is both soil and vegetation upon the platform where the nest is placed, with not unfrequently a small tree growing in front of it. In many it is not more than twelve or twenty feet above the ground, and a man can easily climb to it; again, there is often a great precipice below, and rery little rock above the nest: one was so close to the top that I vaulted easily in and out from the level ground above; near this in the same ravine were three nests of other years, all accessible from below without the aid of ropes; but it is generally through a narrow continuation of the ledge that the eyrie is most easily approached; sheep droppings once gave me a clue to a simple road out of one which I had had much difficulty in reaching, and into another some men and dogs followed me by a simi- 
lar horizontal route. It is common for eagles to have several favourite places in different quarters, and they frequently repair two or three nests before making a final choice of one in which to lay their eggs. The same individuals will select very different situations. I am told of a pair which alternate between a crag quite impregnable and a corner into which a child might climb; but, besides this general change of quarters, the exact site of the nest is often altered from year to year, so that three or four of different ages may be seen within a few yards of each other, and of such I once saw a recently-repaired one, besides that actually occupied; yet some farourite eyries are used for a number of years in succession, ten, twelve, or more years I have often heard mentioned by experienced highlanders other rocks which have scarcely been without eagles in the memory of man. It is evident that they are influenced more by the seclusion than by the inaccessibility of the spot they choose. They do not care for foxes, which often make their earths so as to be conveniently near the well-known larder."

"A more likely rock for an eyrie is a much subdivided one with grassy ledges and well-sheltered corners, than one with a great perpendicular face. Two of the eggs which Mr. Hewitson proposes to figure were, however, in a crag some hundreds of feet in height, and there was scarcely a platform sufficient to support the nest, which, as usual in such cases, was of great size; I know of two or three other similar eyries. The nest itself is made first of sticlis, sometimes in a great mass, but in other situations eren quite dispensed with; where they are used in quantity a few of the largest may be nearly an inch in diameter; upon the sticks is heather, that at the top newly gathered, and in one instance partly re- 
placed by freshly-broken sprigs of the Scotch fir; the lining is of grass, moss, fern, and other vegetable, not animal materials, whatever might happen to be at hand, put in promiscuously; but there is invariably a large proportion of Luzula sylvatica, green outside, but presently dried up in the centre of the nest by the heat of the bird. These tufts become compressed laterally, and look like little pine-apple tops. The whole fabric, though apparently loose, is very firm, and scarcely yields to the weight of a man. It is wide and flat, though, during incubation, there is a well-formed cavity in the centre. It may be at the base five or six feet across. The eggs are laid at intervals of several days."

"The hen sits very close after she begins to lay, so that the first egg is ready to hatch before the second. It is the hen which is always shot in the first instance, and then the cock will take to the eggs for a while; when she is sitting hard it is difficult to make her leave her nest, except by catching her eye from above, or by throwing a stick or stone, as I have more than once experienced. The eggs are hatched at the end of April, and then the forays of the old birds begin to be formidable."

After having seen a number of the eggs of the Golden Eagle, chiefly in the collections of Mr. Wolley and Mr. Walter, I think that the one figured in plate iv. (fig. 1) is the most typical, and not unlike the egg sent me by Mr. Selby for the "British Oology." The second figure in plate iii. represents a rather common variety, the spots being usually more sparing in number and of lighter colour, and like an egg kindly sent me from the collection of Mr. Wilmot. Fig. $\mathrm{l}$ is of unusual beauty, and a good deal like that in the "Eggs of British Birds," from the cabinet of Mr. Adamson. In Mr. 
Walter's collection there is an egg of very unusual colour closely mottled throughout with ochreous brown. The eggs are not unfrequently white, and not easily distinguished from those of the White-tailed Eagle.

The beautiful pair of eggs in plate iii. are from the collection of Mr. Wolley; they were taken by himself from the same nest. 


\section{WHITE-TAILED EAGLE.}

SEA-EAGLE.

\section{Aquila albicilla.}

PLATE IV. FIG. II.

Those who have been in the habit of imagining for themselves a suitable habitation for the eyrie of the king of birds, and associating the name of eagle with the cloud-capped mountain-top, the inaccessible precipice, or the dark ravine, will have their dreams dissipated and be greatly disappointed, when they find, by the long and interesting aoccunt of the habits of the White-tailed Eagle with which I have been kindly favoured by $\mathrm{Mr}$. Wolley, that it is content at times to make its nest upon the ground.

"The Sea-Eagle generally makes its nest in the high cliffs of the coast, where it lives upon fish, guillemots, young herring gulls, \&c., but is also occasionally found breeding inland. In the former situation an eyrie, which I visited two years in succession, and from which I took the egg which Mr. Hewitson figures, had nothing but a very little heather, grass, and moss used in its construction. Two other nests which were carefully described to me were made principally of sea-weed, and were in such "tremendous cliffs" that my informant's "hair gets strong" when he thinks of them. In the Shetlands an inaccessible eyrie was pointed out to me on the extreme 
top of a stack, that is, a steep detached rock; and I have seen another such stack on the north-east coast of Scotland, which was also said to have an eyrie at its summit.

In inland situations the Sea-Eagle is rare when compared with the Mountain Eagle (as the Golden Eagle is usually called), and it generally establishes itself upon a rock or islet in the middle of a loch. Here it builds, upon the ground, or in a tree, a nest, whose construction does not at all differ from that of the other eagle, there being always in it a certain amount of Luzula sylvatica. The tree need by no means be a large one; I have seen two nests of different years in trees on separate islands in one loch, each only about four feet from the ground. I can at this moment call to mind nine instances where I know the localities of such island eyries. The old birds do not always calculate the depth of the water, as there is one place at least to which a man can wade; where swimming is necessary, it is often an affair of danger, as the birds will do their best to drown the enemy with their wings. In two spots I have seen large Scotch firs which have been formerly tenanted by SeaEagles; one by the side of a loch, the other several miles away from any piece of water, in a sort of open wood of similar trees. The nest had been in a fork where three branches met, twenty feet high; and, as in other cases, the main trunk bore its weight. In one instance, the crossed and nearly horizontal trunks of two small trees formed the support; one that I have already spoken of was in a small alder tree, and had been repaired and often frequented by the eagles the season I saw it, yet a hooded crow had eggs in the upper branches, and wild geese and ducks were sitting in the deep moss and long heather within twenty yards. I have not myself 
met with an instance of the golden eagle breeding in a tree or in a sea-cliff, but on the other hand several of the sea-eagle breeding in a rock inland, though not many miles away from the ocean; two such nests that I visited were in small rocks of easy access, in every respect like golden eagles, and in one the hen showed the same unwillingness to leave her eggs. In the summer of 1848, I took out of their nest on a ledge of a perpendicular sea-cliff, two fully-fledged eaglets, which, now nearly five years old, have not (March, 1853) acquired their complete adult plumage, though kept in a most congenial situation amongst the Derbyshire rocks. The eggs of the White-tailed are laid a week or a fortnight later than those of the golden eagle; they are generally smaller."

"The mountain-eagle, as Sir Walter Scott was well aware, is a carrion-eater equally with the-sea eagle; a friend of mine a few years ago saw no less than nine of the two species collected round a dead horse within a hundred yards of the windows of his father's house. In Scotland it is a melancholy reflection that they can scarcely continue to exist much longer: the Whitetailed eagle in its sea-girt fortresses will be the last to disappear. Each inland 'Craig an Eulah' will soon be an empty name."

Latham mentions an instance of this eagle breeding in Cumberland.

Its eggs, two or three in number, are always probably, when first laid, of a spotless white, and afterwards receive as stains, the slight colour with which they are marked, as on the eggs figured in my former works.

Mr. Wolley tells me that eggs of a species of penguin brought home by the guano ships are sold as those of this eagle. 
RAPTORES.

\section{SPOTTED EAGLE.}

SILVER EAGLF.

Aquila Næita.

PLATE V.

THE appearance of two of these birds in Ireland in 1845 , one of which was shot, was first made known by Mr. Davis of Clonmel, and by him communicated to Mr. Yarrell, who has introduced it in his supplement as a British Bird.

In the "Zoologist" for 1846, Mr. Weaver of Birmingham states that he saw a bird of this species in confinement on Valentia Island on the west coast of Ireland, that it was well known there as the Silver Eagle, and that a pair of them had bred regularly on the rocks on the island.

'The Spotted Eagle is met with in most of the Luropean countries, and is said to build its nest on high trees, laying two eggs. The egg which I have figured is from the collection of Mr. Wolley. Others, which have been most liberally intrusted to my care from the collections of $\mathrm{Mr}$ H. Walter and Dr. Frere, are rather less, and marked with blotches of purple and two shades of brown, and much resemble eggs of the common buzzard. 


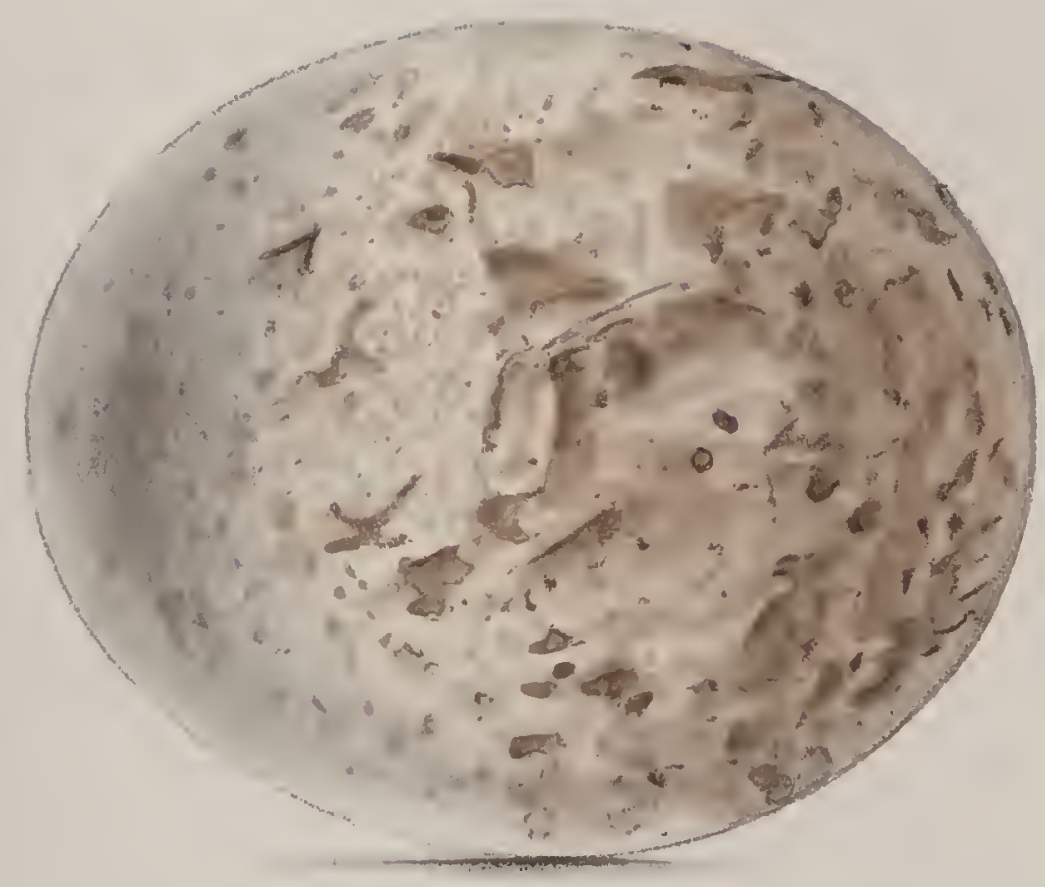



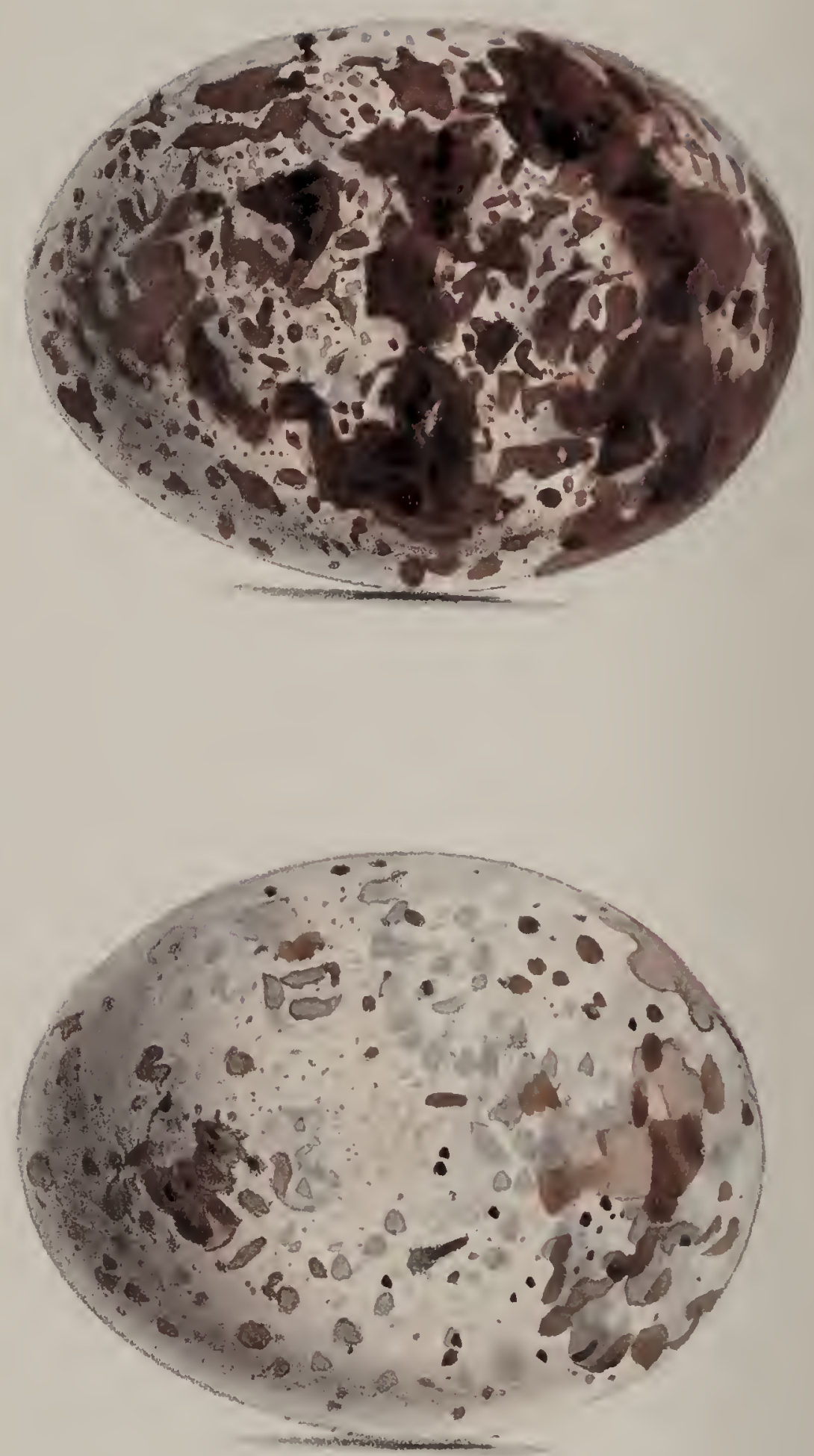


\section{OSPREY, OR FISHING-HAWK.}

\section{Pandion haliaetus.}

PLATE VI.

A NoTe which accompanies the egg figured in former editions kindly sent me by Sir W. Jardine, states that it was procured from Loch Menteith, in Perthshire, a favourite station with the bird; he also states, in his edition of Wilson's "Ornithology," that "a pair or two may be found about most of the Highland lochs, where they build on the ruined towers so common on the edges or insulated rocks of these wild waters. The nest is an immense fabric of rotten sticks, and is generally placed, if such exists, on the top of the chimney, and if this be wanting, on the highest summit of the building. An aged tree may some. times be chosen, but ruins are always preferred, if near."

Mr. Wolley, on the eve of starting for a bird-nesting excursion to the north of Sweden, has sent me the following notes:--. "I have seen several nests of the Osprey upon the highest points of ruins in and about lochs in Scotland, and several more upon small isolated rocks projecting out of the water. There is something in the general appearance of the nest which reminds one of nests of the woor ants; it is usually in the form of a cone cut off at the top; the sticks project very slightly beyond the sides, and are built up with turf and other compact materials; the summit is of moss, very flat and even, and the cavity occupies a comparatively small part of it. I know no 
other nest at all like it. There was a nest for some years on the sloping trunk of a tree which several persons have described to me. The birds are very constant year after year in returning to their old stations, and even after one or both birds have been killed in the previous season I have frequently" seen individuals flying near the now deserted eyrie."

Mr. Hancock has described to me the situation of a nest from which he took the eggs. It was placed upon the highest point of a ruin, standing on an elevated piece of ground surrounded on all sides to a distance by a beautiful unbroken slope of grass, giving the bird an uninterrupted view of any approaching foe.

Mr. Selby mentions his having seen the Osprey on Loch Awe, "where an eyrie is annually established upon the ruins of a castle near the southern extremity of the lake, and another in a similar situation, nearly opposite the egress of the river Awe."

With all their ingenuity Ornithologists have not been able to puzzle out a distinction where there is no difference between the American Osprey and our own.

For a further account of this species I have therefore had recourse to the faithful description of Wilson, whose opportunities of observing it were frequent, for so abundant is it in America, that no less than three hundred nests have been counted at one time on an island near New York, the old birds living together peaceably in close proximity, like so many rooks.

"The nest of the Fish-hawk is usually built on the top of a dead or decaying tree, sometimes not more than fifteen, often upwards of fifty, feet from the ground.

"It has been remarked by the people of the sea-coast that the most thriving tree will die in a few years after being taken possession of by the Fish-hawk. 
"This is attributed to the fish-oil, and to the excrement of the bird, but is more probably occasioned by the large heap of wet salt materials of which the nest is composed. In my late excursion to the sea-shore I ascended to several of these nests that had been built in from year to year, and found them constructed as follows: externally large sticks, from half an inch to an inch and a half in diameter, and two or three feet in length, piled to the height of four or five feet, and from two to three feet in breadth; these were intermixed with cornstalks, sea-weed, pieces of wet turf in large quantities, and lined with dry sea-grass, the whole forming a mass observable at half a mile's distance, and large enough to fill a cart, and form no inconsiderable load for a horse. These materials are so well put together as often to adhere in large fragments after being blown down by the wind.

"During the time the female is sitting the male frequently supplies her with fish, though she occasionally takes a short circuit to sea herself, but quickly returns again."

It will be seen that some of the sticks which Wilson mentions as forming a part of the Osprey's nest, would form a very substantial walking-stick.

The Osprey, in this country as in America, lays its eggs in the beginning of May; they are sometimes two, almost always three in number. Wilson says rarely four. They are more oral in form than those of any of our British Falconidæ; they do not usually differ much. The second figure of the plate is a rare variety from the collection of Mr. Hancock. Mr. Wilmot has kindly sent me some American eggs to compare with our own, from which they differ in being somewhat more sombre, but this may not hold good in comparing a larger series. 
RAPTORES.

\section{ICELAND FALCON.}

\section{Falco Islandicus. (Hancock.)}

PLATE VII.

AT the meeting of the British Association in Newcastle, Mr. John Hancock cleared up, to the satisfaction of the Ornithologists there present, all those doubts which had previously existed with regard to the Gyr Falcon; he has since, too, had opportunities of examining a large series of both the Greenland and lceland birds, and of verifying and confirming his former opinions on the subject.

Ornithologists, though unable to settle the question, had pretty generally come to the opinion that there was but one species, and that the White, or Greenland specimens, were merely varieties of age of the Grey, or Iceland bird. Faber, who spent some time in Iceland, and paid great attention to the subject, finding that the Falcon of that country retained the dark grey plumage during the breeding-season, was induced to consider the white birds which he saw only in the winter months, as albino varieties of the former.

All these difficulties $\mathrm{Mr}$. Hancock has got rid of, by proving that the beautifully-marked black and white birds are of a distinct species; that the Falcons attain their mature dress at the first moult, and that although both the species are very much alike when young and in their nesting plumage, yet that the bird which remains in Iceland the year through, and which must retain the name of 
VII.

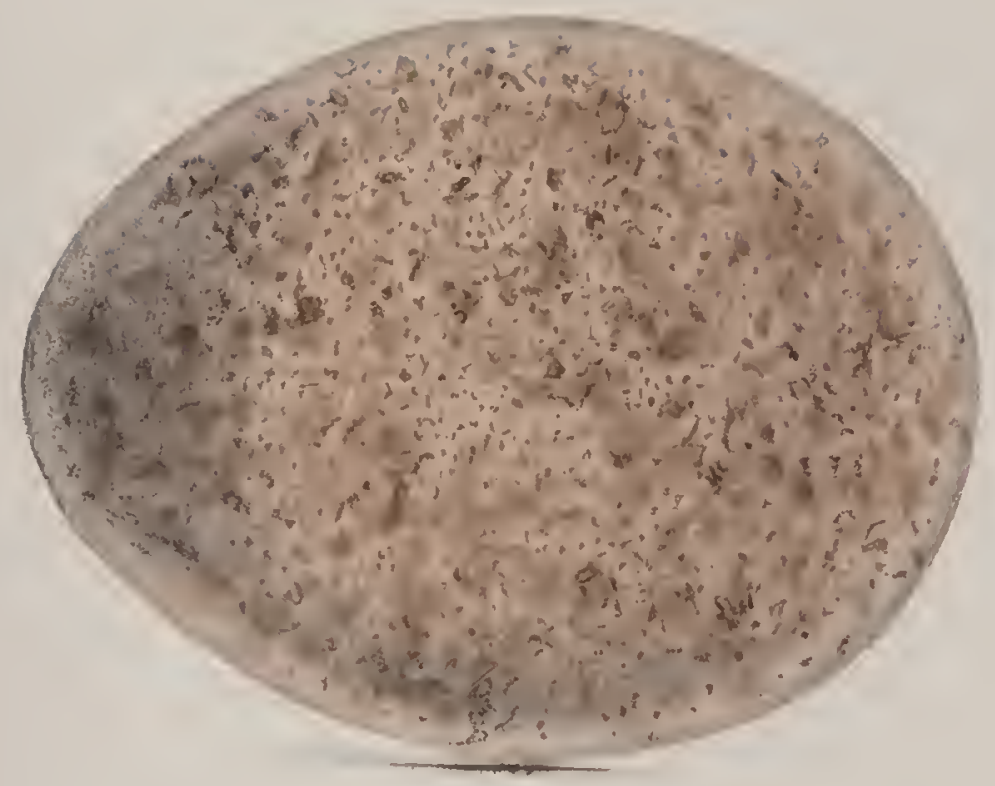



Islandicus which he proposes, never attains the variegated plumage of the Gyr or Greenland Falcon figured by Mr. Yarrell.

The egg figured in the former edition was taken by $\mathrm{Mr}$. Proctor, the curator of the Durham University Museum, from the nest of the true Iceland Falcon, whilst on a visit to that country. He had gone out for the purpose of collecting birds and their eggs, but did not reach the favourite localities of the Iceland Falcon till the broods were flown. This was in the beginning of August, when he shot several full-grown young ones, and found some of the deserted nests; the one from which he took the egg then drawn was composed of sticks and roots, lined with wool, amongst which the egg, a rotten one, was embedded. He supposes that the nest may have been that of a raven, which is most probable, as it nuch resembled one. The remains of many birds, whimbrels, golden plovers, guillemots, and ducks, lay strewed about the nest. 'This nest and others which Mr. Proctor saw were all in the cliffs, forming the boundary of fresh-water lakes, but none of them so high in the mountainous districts as he expected to have found them.

The egrgs of the Iceland Falcon, of which I have several by me from the collections of Mr. Wilmot, Mr. Walter, and Mr. Wolley, and of which I have now seen a numerous series, do not vary much; they are never dark, like those of the peregrine falcon, but, like the figure of the plate, are mottled uniformly throughout, much more like eggs of the hobby than any other bird; and like them, too, they are sometimes alınost white or sparingly freckled. An egg sent we from the collection of Mr. Salnon has very little colour, except at the larger end. 


\section{PEREGRINE FALCON.}

\section{Falco peregrinus.}

\section{PLATE VIII.}

The Peregrine Falcon is much too large a bird to escape for any length of time the prying eyes of the gamekeeper. It is, therefore, confined to those wild districts which he rarely visits, and most of its breeding-places in this country are in the highest and least accessible cliffs of our sea-coast, to which it will return for many years together.

The Rev. W. D. Fox informs me that a pair of these birds have frequented the rocks of the Isle of Wight, and although annually plundered of their eggs or young ones, have for many successive years returned to the same spot; and what is more remarkable, although one of the sexes has been sometimes shot, the remaining bird has never failed to bring a mate with it the following spring.

The eggs which I have figured before were sent me by the Rev. James Smith of Monquhitter, and were procured by him from the fine rocks which bound the Murray Firth. Macgillivray says that the Peregrine breeds on the Bass Rock, the cliffs near Tantallon Castle, May Island, and St. Abb's Head. Holyhead and Great Ormes Head are mentioned by $\mathrm{Mr}$. Yarrell, and very many other places of its resort might be enumerated along most of the precipitous coast of Great Britain and Ireland. Mr. Wolley tells me that it not unfrequently breeds in church-steeples in the 
VIIII
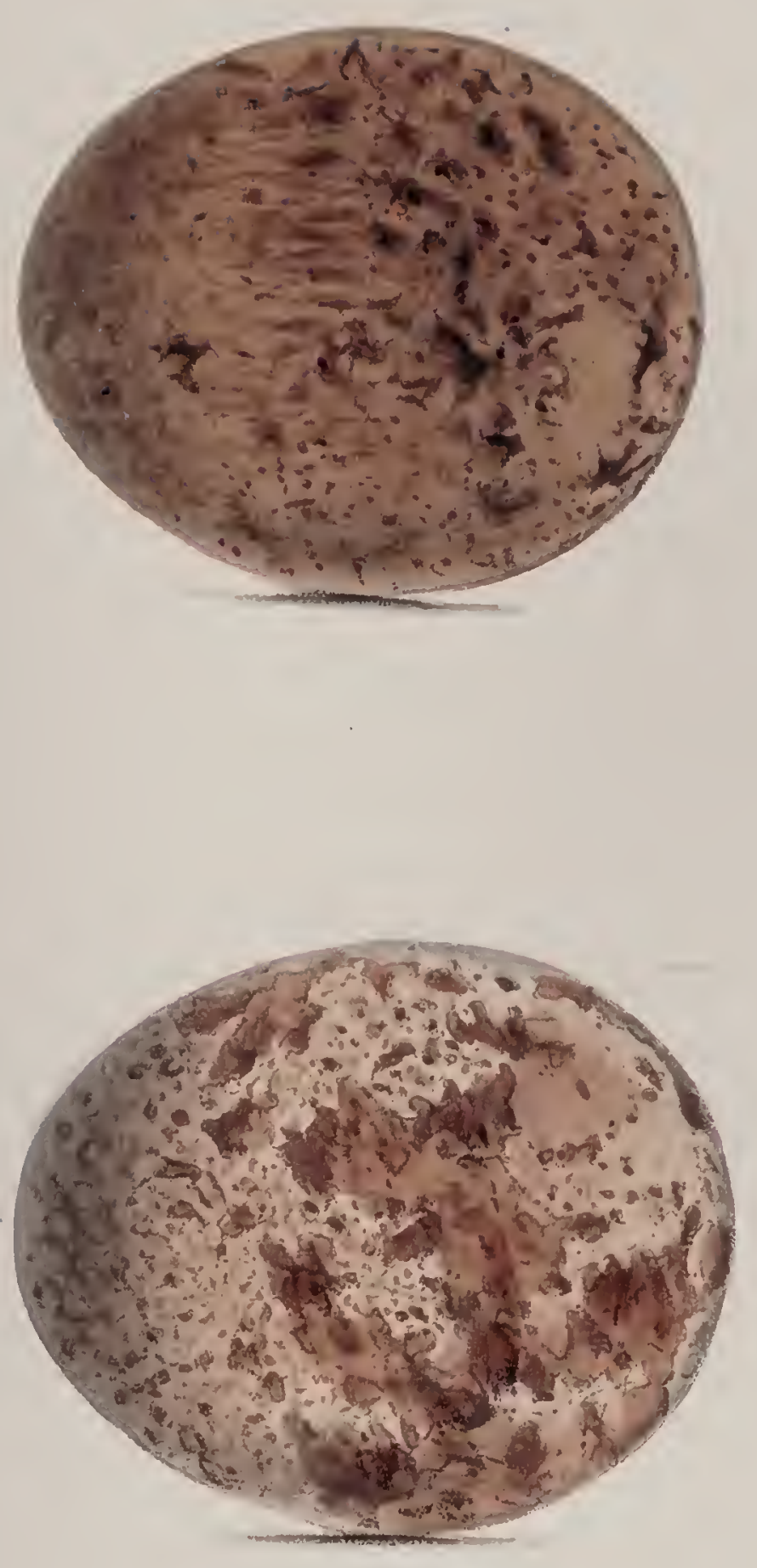

thickly-peopled centre of a city, and that he has seen it on the cathedral at Antwerp.

The Peregrine Falcon usually takes possession of the nest of some other bird (Mr. Wolley says of the Raven) in which to lay its eggs, and I doubt whether it ever makes a nest of its own, otherwise different pairs of birds would not so greatly differ in this respect. Whilst some are content with a bare stone-floor upon which to rear their young ones, or deposit their eggs upon a few bones, others are much more comfortably lodged, sometimes, certainly, if not always, in the usurped or abandoned nest of another species.

The eggs do not greatly differ in colour. I have seen none about the identity of which I could have any hesitation. The second figure of the plate, from the collection of $\mathrm{Mr}$. Wilmot, is one of the most aberrant varieties I have seen. The eggs differ, however, very considerably in size, some being one-third less than others, most probably those of young birds. They are three or four in number. Audubon mentions a nest which contained five. 


\section{HOBBY.}

\section{Falco subbuteo.}

PLATE IX. FIG. I.

'Tis beautiful species of hawk is, I believe, rare throughout the country, and, as far as my own observation goes, is more common in some parts of Yorkshire than clsewhere; not, however, having had an opportunity of seeing much of its habits, I avail myself of the information of Mr. Hoy.

He informed me, that the Hobby is a late breeder, seldom haring eggs before the first week in June; that it very rarely, if ever, builds its own nest, but takes possession of that of a crow or magpie, preferring those which are placed near the tops of high trees; and " though it may be met with breeding in large woods, seems rery partial to isolated groves of fir and other trees situate in an open country, where it can not only pursue with advantage the feathered tribe, but also capture vast numbers of coleopterous and other insects, upon which it feeds very much."

When in Norway we met with a nest of the Hobby, placed upon a projecting ledge of rock, on the face of a steep precipice, which, overhung with brushwood, formed a part of the beautiful scenery of one of the lovely lakes of that country. This was in the month of June.

Mr. Aikin says that it used to breed in Huntingdonshire previous to 1835 , in which year he procured some of 

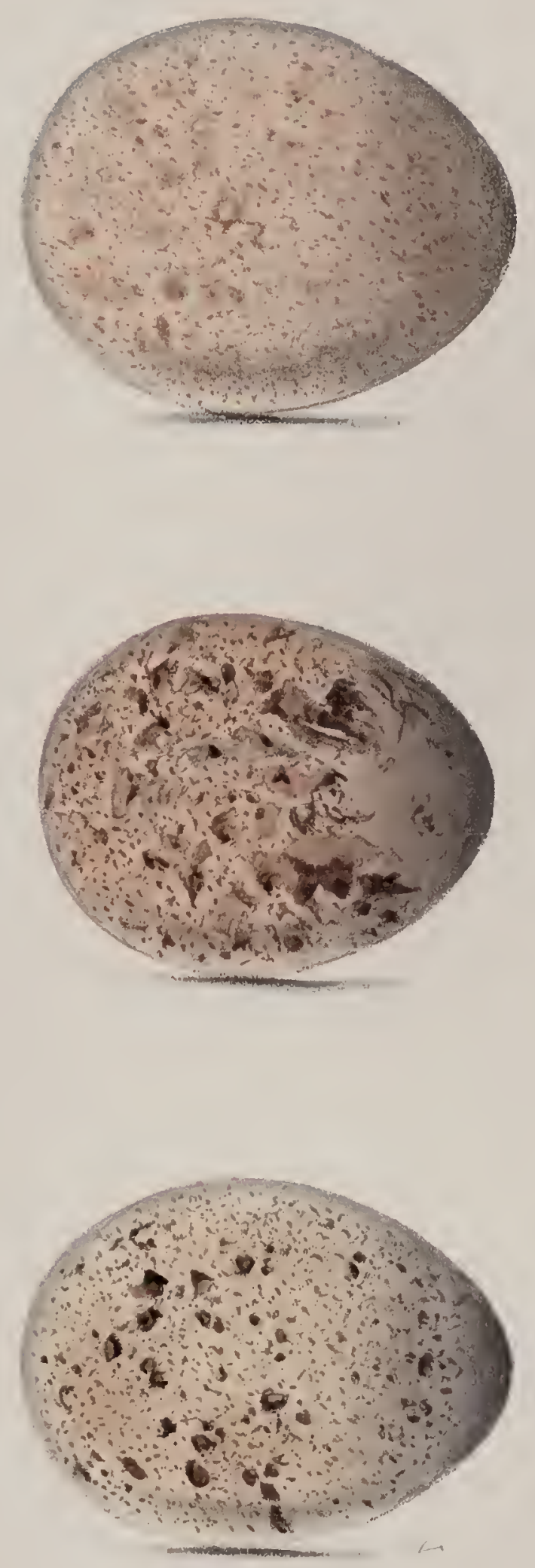

the young birds, but that he has not heard of a nest since that date.

The Hobby lays sometimes only two, but for the most part three eggs. Mr. Hoy told me that he had never met with more. As far as I have had an opportunity of seeing them, they are not subject to much variety; one specimen only, which I have previously figured, was remarkable for the absence of all the deeper red colouring. They are usually very regularly freckled over the whole surface, and more nearly resemble eggs of the Iceland falcon than those of any other species. The darkest varieties are rather like some lightly coloured eggs of the kestrel; they are, however, of a pinker hue and without any large blotches of colour. Mr. Macgillivray's description of them is quite incorrect. The eggs described by him are most likely those of the sparrow-hawk. 
RAPTORES.

\section{RED-FOOTED FALCON.}

\section{Falco vespertinus.}

PLATE IX. NIY, II. III.

IT is a pleasure to welcome a new bird as British upon a claim so good as that of this species. Besides the eight instances of its appearance in this country recorded by Mr. Yarrell, others have since been noticed in the pages of the "Zoologist," by Mr. Gurney and other correspondents. Mr. Cockrane had the good fortune to meet with this species in Hungary during the breeding season, and by him I have been supplied with a series of the eggs to draw and the following very interesting information. The Red-footed Falcons arrive in the country about the middle of April, and have laid their eggs early in the following month. They make no nest for themselves, but, after a fight with the lawful owners, take possession of those of the crow, rook, or magpie, altering or repairing them according to their own taste. Mr. Cockrane says, that he has found their eggs in a nest of Corvus corone, that they are sometimes even six in number, but most commonly four or five, "sometimes in isolated trees, at other times as many as six or seven pairs in one tree, in a rookery, exactly as rooks in England." Mr. Cockrane must have been as much surprised when he found these birds breeding in company as we were when we first discovered colonies of fieldfares in Norway. The eggs most nearly resemble those of the kestrel, being, however, for 
the most part considerably less; like the eggs of that bird, they are sometimes fincly freckled throughout, and sometimes like figure three of the plate (a variety which the egg of the kestrel is also subject to), much resembling eggs of the red grouse.

Mr. Newcome of Hockwold Hall, well known as one of the few English gentlemen who still pursuc the most interesting sport of Falconry, has obligingly sent me the following information, which is fully confirmed by the account given me by Mr. Cockrane.

"I have been informed, on what I consider very good authority, that the Red-footed Falcon breeds in societies. An old Dutch Falconer told me some years ago, that once, when he was in Hungary, he was unable to procure any rooks at which to fly his hawks. One day, however, he saw at a distance what appeared to him to be a rookery, and accordingly he repaired to it. To his surprise be found that the nests which he had supposed to be those of rooks were the property of a colony of Red-footed Falcons." 


\section{MERLIN.}

\section{Falco esalon.}

PIATE X, FIG. I.

THE eggs of the Merlin, as far as any notice occurs of their detection in this country, have been found deposited upon the ground, and chiefly upon those extensive heathy moor's which abound in the north of England. Temminck, however, says that the Merlin breeds in trees; and this, I think, is very probably the usual case in those districts which abound in wood. Were we to judge from the colour of its eggs, we should be led to expert that such was its usual habit, since the eggs of the other groundbuilding raptorial birds are white, or nearly so. These are, in their turn, represented amongst the arborial breeders by the white-tailed eagle and the goshawk, which lay eggs that are also white, or rarely slightly coloured. Whilst in Norway we had the eggs of a hark brought to us which had been taken from a tree, and which I have not the least doubt were those of the Merlin, as they correspond exactly with the figure of the plate both in colour and in size, and were less than the usual eggs of the kestrel. We also noticed a pair of these birds in a thick part of the forest, which, during our stay in their neighbourhood, evinced so much of that solicitude which birds do on your approach to their nests, that we felt quite sure theirs could not be far distant. So thick and tangled were the trees and brushwood, that it was not till after a 

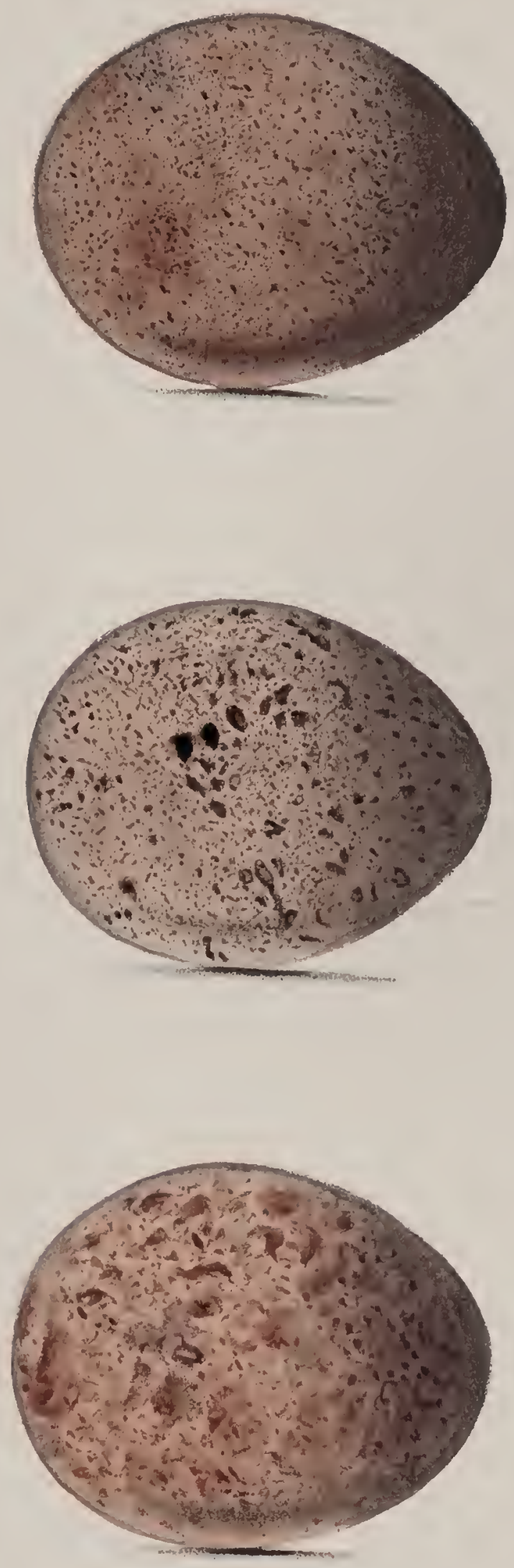

weary and laborious search that we were rewarded by its discovery. It was near the top of a tall spruce fir-tree, and had every appearance of having been newly made by the birds themselves. It was outwardly of sticks, thickly lined with wool.

The Merlin, as far as my information goes, can scarcely be said to make a nest when it deposits its eggs upon the ground, laying them either upon the bare heather, or on a small quantity of dry grass; they are four or five in number, and for the most part differ little from the plate; in their usual colouring they resemble one of the varieties of the eggs of the kestrel figured in the following plate, but are usually smaller, browner, and less bright in colour, very closely freckled, not spotted, and thickly sprinkled over with small black dots.

Mr. Walter's collection contains some eggs remarkable for their deep red-brown vinous colouring.

Some of the varieties might more readily be mistaken for eggs of the kestrel. One sent me from a nest of five in the collection of Mr. Wolley, unfortunately too late to figure, is one of the most beautiful eggs I have ever seen. The ground colour is of a pure white, thickly blotched with crimson red. Similar eggs are also in the collection of Mr. John Hancock of Newcastle. 


\section{KESTREL.}

\section{Falco tinnunculus.}

\section{PL.ATE X. FIG. II. III.}

I AM inclined to believe that the true falcons very rarely make a nest for themselves. It is well known that the Kestrel most frequently takes possession of that of some other bird in which to rear its young ones. It breeds not uncommonly in most of our woody districts, laying its eggs in the nest of a crow or magpie.

In those bare and wilder places to which it also frequently resorts, it either makes its own nest, or uses that of the raven or the jackdaw, upon the ledge of some rocky steep, or on the walls of some crumbling ruin.

Mr. Macgillirray says, that in Scotland "twenty nests of this species might be pointed out in rocks for one in a tree," and that a pair have bred in the castle rock of Edinburgh for many years. They breed amnually on the top of an old tower in Oatlands Park, in the company and on friendly terms with a coiony of jackdaws. Mr. Gurney, in a notice in the "Zoologist," mentions a nest of the Kestrel which was placed in the hollow trunk of a pollard oak. Mr. Waterton had one summer no less than twenty-four nests of this species in his park at Walton, and comes to the conclusion that, "allowing four young ones to the nest, there must have been bred here ninety-six windhover hawks last summer; add the parent birds, and we shall have in all one hundred and forty-four." 
The eggs are four or five, and sometimes, though rarely, six in number; they are beautifully varied and richly coloured; some of them are suffused over their whole surface with red, closely freckled with darker colour, and much resembling in this variety eggs of the Merlin; others are blotched with deep colour; whilst intermediate varieties occur with a greater proportion of light groundcolour, and a good deal resembling some eggs of the sparrow-hawk, but always of a redder hue.

I often think with pleasure of a pet Kestrel which was my companion when at school. It had been reared from the nest, and used to enjoy so much of its native freedom, in long flights round the neighbourhood in which we lived, that it never seemed desirous altogether to regain it.

Many a time, when sailing high in air, it would pounce down at iny call, and quietly settling on my arm, remain to eat the food which I had brought it. Sometimes, greatly to my consternation, whilst at our daily lessons, it would enter the open window and fly, loudly screaming, round the school-room. 


\section{GOSHAWK.}

\section{Astur palumbarius.}

\section{PLATE XI.}

Mr. Low, in his "Fauna Orcadensis," says that the Goshawk is rather common there, breeding in the rocks of the sea-coast. Whatever may have been its numbers in his time, it is not now to be met with either in Orkney or the adjacent isles of Shetland. The peregrine falcon may sometimes be seen there; and I much suspect that it is the Goshawk of Mr. Low.

The Goshawk is a scarce bird with us, and has rarely been detected breeding in this country. Mr. Selby says, that it " is known to breed in the forest of Rothiemurchus and on the wooded banks of the Dee."

It is to be met with during the summer season in the extensive forests of Hollan!, Germany, and various parts of the Continent; and, Mr. Hoy informs me, builds its own nest, and; if undisturbed in its possession, will frequently occupy it for several years, making the necessary repairs. It is placed in some high tree on the outskirts of the forest, and is rarely found in the interior of the woodland, except in those parts which are cleared, and fiee from timber.

The eggs are three or four in number, and are frequently hatched by the middle of May; they are, I believe, for the most part spotless, but are sometimes indistinctly marked with brown. 
X?

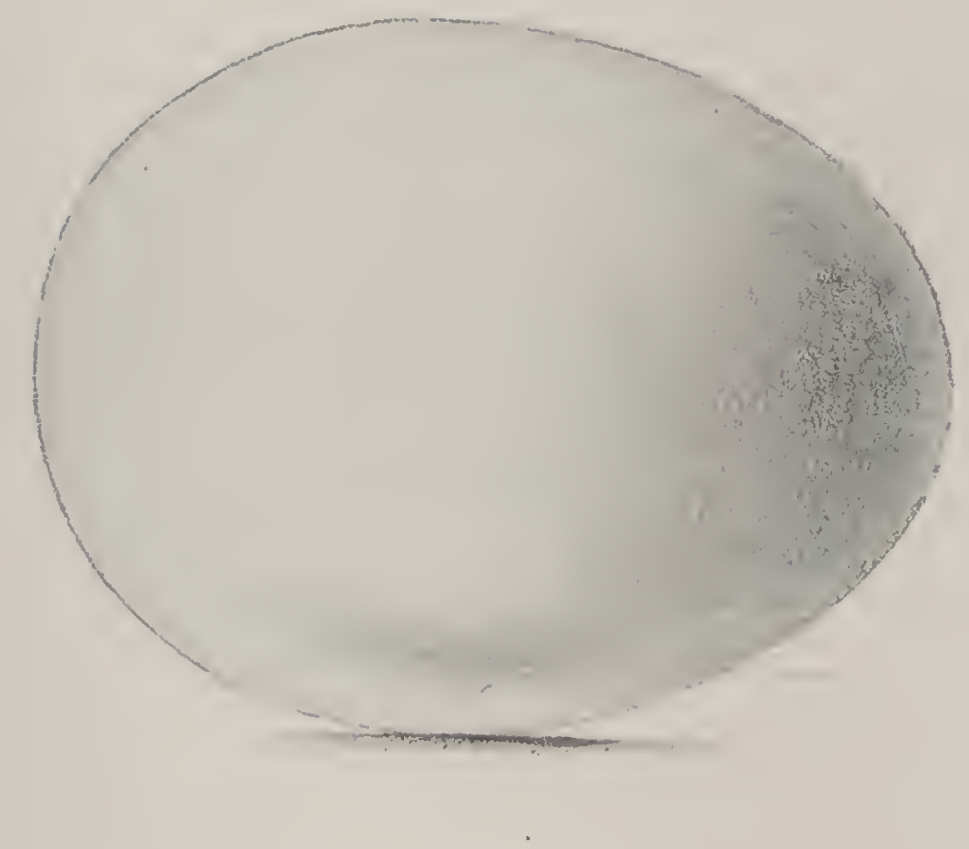





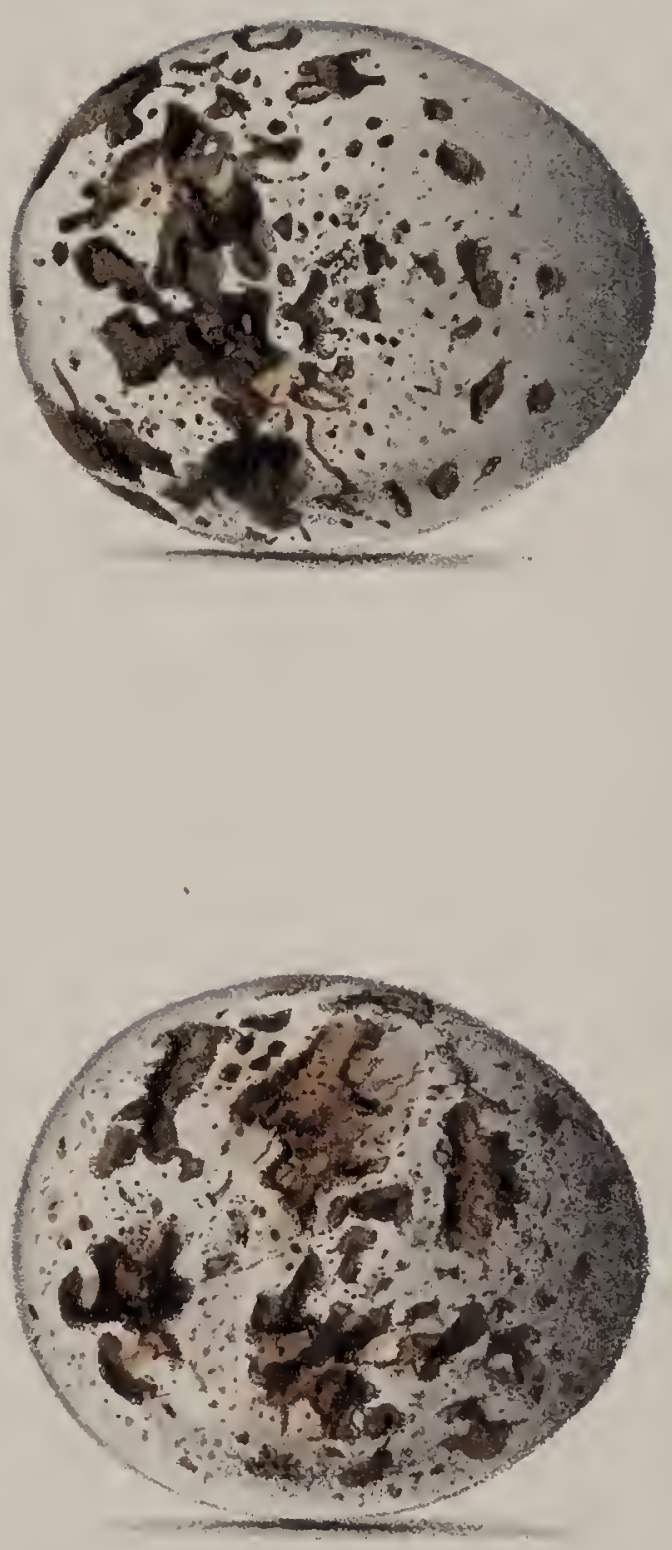


\section{SPARROW-HAWK.}

Accipiter nisus.

PLATE XII.

ThE Sparrow-Hawk, although one of our commonest birds of prey, is not nearly so numerous as the kestrel. Its eggs may sometimes be found upon the ledge of some lofty cliff, but are much more frequently to be met with in trees, for the most part occupying the usurped nest of a crow or magpie; sometimes it would appear, however, in a nest of its own construction. Mr. Selby says, that it occasionally makes its own nest in low trees or thornbushes, that it is flat and shallow, and very similar to that of the ring-dove, but rather larger, and is composed of slender twigs.

The eggs of the Sparrow-hawk, although usually very readily distinguished from those of any other species, are subject to varieties which sometimes rather resemble those of the kestrel but are never marked with the same rich crimson colouring.

There are some specimens, on which all the markings are very obscure and indistinct; and others on which all the dark blotches of colour are at the smaller instead of the larger end. I know of no egg which is so subject to this variety. Mr. Walter's collection contains one that is white, except a few black dots; another that is pointed at the smaller end like the egg of a wader. 


\section{KITE.}

\section{Milves vulgaris.}

PLATE XIII.

'The Kite appears to be, from choice, rather local; whether so or not, it is now in England confined to some of our largest woods. Dr. Heysham, speaking some years ago, says that it breeds in the woods near Armathwaite and Ullswater. Macgillivray says, that, "from Stirling and Perth westward it is often seen, and in some parts of the counties of Dumbarton, Argyle, and Perth cannot be considered scarce." Mr. Selby says, that "it occurs plentifully in Aberdeenshire." I have seen it in the vicinity of Loch Katrine, and have had the pleasure of watching its graceful circling flight from the beautiful banls of Loch Awe; and have frequently seen two or three together when passing the woods in the neighbourhood of Alconbury Hill, its well-known breeding place; and here, Mr. Wolley informs me, there were still some left in 1844, but that the last of them have been since destroyedthat " in the northern districts the value of some of its feathers to the salmon-fisher has greatly contributed to its destruction." Mr. Wolley has also sent me the following very interesting notes:- "It was formerly so abundant in the streets of London, that several risitors from the Continent have made a note of their surprise at its numbers and familiarity. A learned writer in the 'Quarterly Review,' in an article upon the Bohemian Embassy 

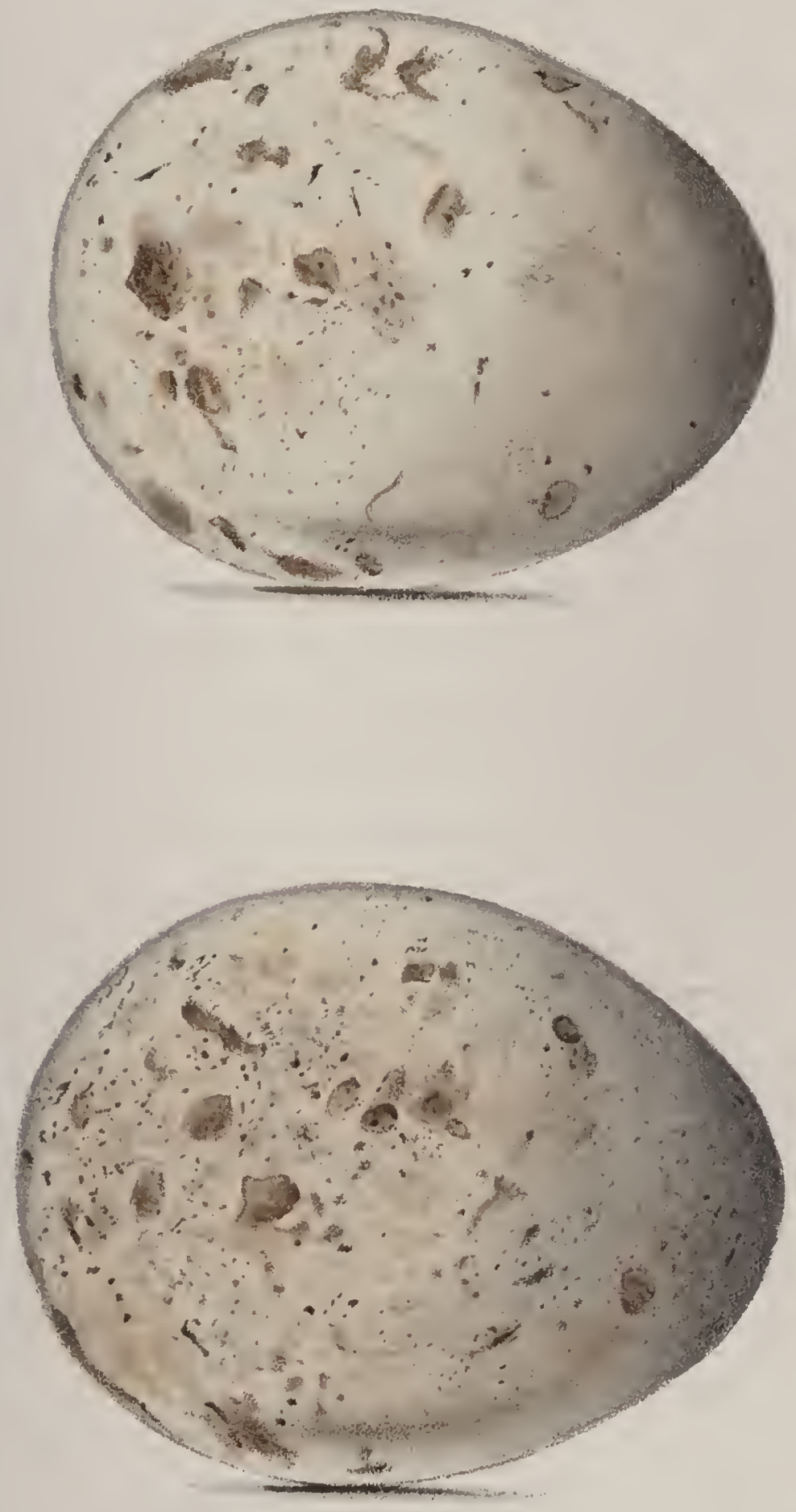

to England some four hundred years ago, supposes that the word 'Milvi,' in Schassek's Journal, must have been a mistake for 'cygni,' as London had always been celebrated for swans; but other old writers leave no room for doubt that the Kite was the most familiar bird with the citizens of old London. How few of the persons who sce the paper toys hovering over the parlis on fine days of summer, have any idea that the bird from which they derive their name used to float all day in hot weather high over the heads of their ancestors! They were resident in England all the year, whilst in Italy and Greece they entirely disappeared during the winter, and were looked upon as the harbingers of spring."

In the Zoological Gardens last year a pair of Kites made their nest upon the ground, in the corner of their cage, and the female sat for a long time very seduously upon her eggs.

The Kite builds its nest in the fork of a large tree. It is composed of sticks, lined with dry grass, wool, and other soft materials. It lays three or four eggs, which do not greatly vary; but in some of their varieties are not to be distinguished from eggs of the common buzzard, by which they are represented in the collections of those who take them upon the authority of a dealer.

Mr. Walter has some beautiful eggs of this species; one closely covered all over with light rufous blotches; another with beautiful tints of lilac and purple, relieved with brown. 
RAPTORES.

\section{COMMON BUZZARD.}

\section{Buteo vulgaris.}

PLATE XIV. FIGS. I. 11.

The Common Buzzard is, with all the larger birds of prey, driven to seck shelter in a ferw of our more extensive woods, far from which it is rarely seen. Its nest is built in trees, and is composed of sticks, lined with a quantity of wool, fur, and such-like soft materials. In Scotland, where it is more numerous than with us, Mr. Wolley tells me that it inhabits districts quite without trees, making its nest - which is very much like an eagle's, except in size, and lined with the same kind of dry grass - upon the ledges of rocks. Mr. Macgillivray says, that "it chooses for its nest a shelf of a rock, or the edge of a steep scar or bed of a hill torrent, and forms it of sticks, twigs, and heath, with a rude lining of wool and grass."

The eggs, which are three or four in number, vary according to the age of the bird, and are sometimes of a spotless white. Those from which the plate is drawn, are from the collection of Mr. Wolley, and were taken by himself in Sutherlandshire. An egg in Mr. Walter's collection is beautifully coloured with different tints of purple and lilac. Mr. Wingate had the eggs brought to him from the same place for several successive years - no doubt the produce of the same bird. The first year they were white, or nearly so; the second year slightly marked with indistinct yellowish-brown; increasing each year in the intensity of thcir colouring till the spots became of a rich dark brown. 

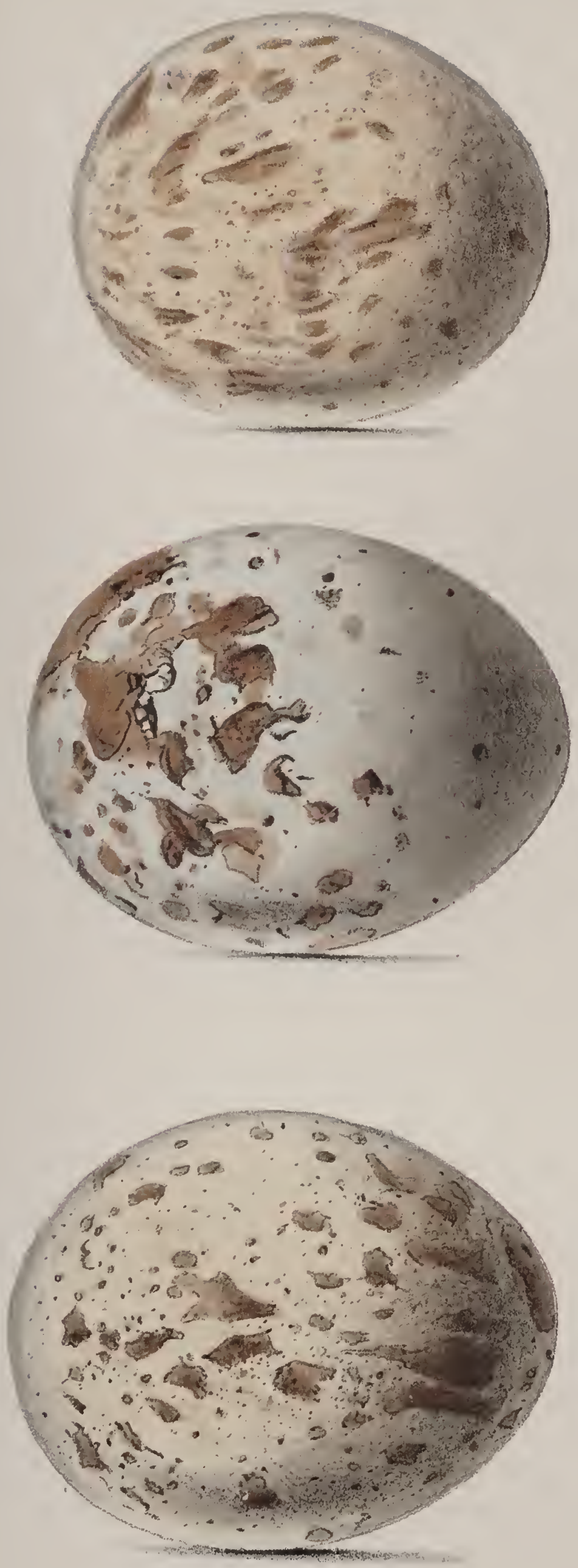



\section{ROUGII-LEGGED BUZZARD.}

\section{Buteo LAGOPUS.}

PLATE XIV. FIG. III.

IT was not known till communicated through the pages of Mr. Yarrell's "Birds," that the Rough-legged Buzzard was more than a temporary visitor of this country.

It is however there stated, upon the authority of $\mathrm{Mr}$. Williamson of Scarborough, and I have pleasure in confirming that statement, through the kindness of my friend, James Tuke, of York, who has visited the neighbourhood, and made personal inquiries on the subject, "that it occasionally breeds in a precipitous dell near Hackness in Yorkshire, and that a marked female returned a second year with a new mate to her favourite haunt."

The Rough-legged Buzzard is an abundant species in some of the extensive forests of Germany. I noticed several, whilst travelling through some of the wilder parts of Baden and Wirtemberg, hunting orer the vineyards and fields of Indian corn which border on the woody districts. It breeds, like the other allied species of bawks, in precipitous rocks and lofty trees, laying from three to five eggs, differing considerably in their colour; some specimens being nearly white, whilst others are darker and more blotched with colour than the one from which I have drawn my figure. They differ so little from eggs of the Common Buzzard, that no dependance can be placed upon those being genuine which pass through the hands of a rlealer. 


\section{HONEY BUZZZARD.}

\section{Pernis apivorus.}

YLATE XY.

A Much greater number of this species have of late been noticerl as vistors of our island than had been for many previous years recorded.

They have occurred during the last few years in various parts of England, and amongst several instances of their appearance in Northumberland, Mr. John Hancock has singularly obtained two fresh specimens, picked up dead upon the sea-shore.

It seems, however, to have been more numerous many years ago. Willoughby mentions a pair which made use of an old nest of the kite to breed in, and further states that the Honey Buzzard builds its nest of twigs, lining it with wool; and White thus refers to one at Selborne: " $\mathrm{A}$ pair of Honey Buzzards built there a large shallow nest, composed with twigs, and lined with dead beechen leares, upon a tall slender beech near the middle of Selborne Hanger, in the summer of 1780. In the middle of the month of June, a bold boy climbed the tree and brought down the egg, the only one in the nest, which had been sat upon for some time, and contained the embryo of a young bird."

I must regard that ignorance as bliss which was productive to the ornithologist of the following interesting information; to myself of a pleasant correspondence and a lind friend. I now copy from the pages of the "Zoolo- 

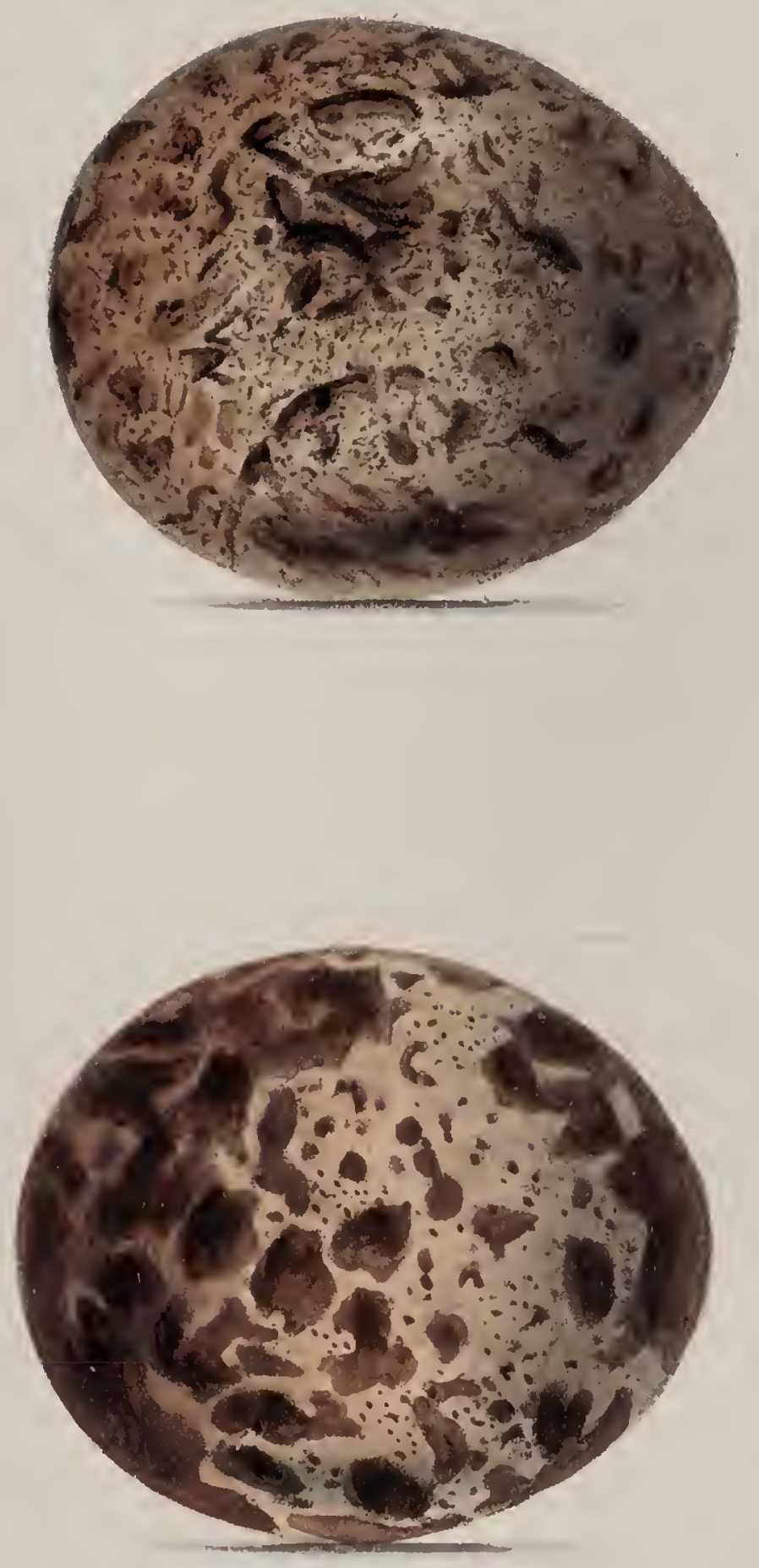

gist" Mr. Wilmot's own words, communicated in 1844. He says, "A remark made by $\mathrm{Mr}$. Hewitson in his beautiful work on the eggs of British birds, now in the course of publication, 'that there is no recent instance of the Honey Buzzard having bred in this country,' leads me to believe that the following statement may possess sufficient interest for insertion in the 'Zoologist.'

"Early in the month of July, 1838, a female Honey Buzzard was shot off her nest in Wellgrove-wood, in the parish of Bix, near Henley-on-Thames, by a gamekeeper of Lord Camoys, named Lowe. The bird, with two eggs taken from the nest, passed into the hands of a birdstuffer at Henley, of the name of Hewer. I was then resident in the Temple, and being an eager collector of the eggs of British Birds, had engaged a young friend, Mr. Ralph Mapleton, then living at Henley, to secure for me any rare eggs that he might have an opportunity of obtaining. Mr. Mapleton communicated to me the above occurrence, and at my request purchased the eggs for me. The male bird, which continued to haunt the neighbourhood of the nest, was not long after killed by another of Lord Camoys' gamekeepers. The nest, a very large one, was placed in the fork of a beech tree, and was built of sticks of considerable size, with which were intermixed twigs with the leaves on. The lining was composed of leaves and wool. A great portion of the nest was, I am told, remaining in the tree a short time ago."

Mr. Wilmot, having ascertained that a pair of Honey Buzzards, male and female, had been sent to Birmingham to be stuffed, and that they had been procured by $\mathrm{Mr}$. Potts, Lord Leigh's gamekeeper, learned from him that he had shot them from an unfinished nest in Waverley wood near Stoneleigh Park; "that it was built in an oak tree, rather a large one, near the middle of the wood, 
and rested on two large arms which grew out from the trunk, and was built with sticks, some of them as thick as his finger ;" and that his brother had "shot a Honey Buzzard off its nest in the same wood some ten years ago," that nest also being built between three large arms just at the top of the trunk. Mr. Wilmot goes on to say, "I had particularly asked whether boughs, or twigs with the leaves on, formed part of the materials with which the nest was constructed, in order to ascertain whether it resembled the nest near Henley in that peculiarity, if it should be so termed, for the presence of boughs with the leaves on merely proves that the Honey Buzzard, like the rook, does not use dead materials only in constructing its nest. Live boughs plucked at the season at which these nests were built, would necessarily be clothed with leaves. June seems to be the usual season of nidification in this country. White's nest was robbed in the middle of June, the nest at Stoneleigh was not completed when the birds were shot about the 10th of June. The nest near Henley contained eggs in the early, part of July, and the young birds mentioned by Willonghby were fed with the nymphæ of wasps, which would not be obtained before the end of July. And, as far as can be collected from the recorded instances, there seems to be reason for supposing that the number of eggs laid by the Honey Buzzard is below the number usually laid by birds of prey of corresponding size. In the instance mentioned by White, the single egg found in the nest contained the embryo of a young bird; the nest mentioned by Pennant, contained two eggs; and the nest mentioned by Willoughby (I am arailing myself of the information collected by Mr. Yarrell), contained two young birds. The nest near Henley contained two eggs only, and the state of the 
eggs indicated that the bird had accomplished full one half of her period of incubation, and had consequently laid her complement."

The eggs are two in number, and, judging from a considerable series, are not subject to much variety, and are coloured in a way which, though at once showing their relationship to others of the same family, is nevertheless very peculiar, and characteristic of this species, and unlike those of any other bird. The colouring matter seems to have been profusely supplied, and is thickly spread over almost the entire surface of the egg.

The first figure of the plate is from the English egg mentioned by Mr. Wilmot, and now in his collection. The other has been kindly lent me by Dr. Frere.

An egg in the rich collection of $\mathrm{Mr}$. Walter, is oblong in form, and so thickly smeared with brown, that no light ground-colour is visible. 


\section{MARSH HARRIER, OR MOOR BUZZARD.}

\section{Circus rufus.}

PLATE XVI. FIG. I.

'THE naturalist may raise his protest against the wanton destruction of the objects of his admiration, as Mr. Wilmot has done in the pages of the "Zoologist," and deserve the thanks of his fellow men. But when a whole race of beautiful beings are becoming exterminated for the general good, when the dreary waste is becoming a fruitful field, and the bulrush is about to give place to the blade of wheat, he must grieve in silence.

From the fens of Cambridge and the adjoining counties, a few years ago frequented by numbers of the three species of Harrier, they are now driven by the ploughand will probably, ere long, like one of our most beautiful British butterflies, once an inhabitant of the same district, become extinct in this country. Mr. Alfred Newton, of Elveden, tells me that a great many of the three Harriers used to breed in some of the fens of Norfolk, but that they have been driven away by the superior system of drainage-that " the Moor Buzzard was the first to cease from breeding there, then the Hen Harrier, and, lastly, the ash-coloured species."

Montagu, in describing the eggs of the Marsh Harrier, says, that they are "perfectly white, without spot;" Latham, on the contrary, in his description of the eggs of the same species, that they are "spotted with brown." 
111
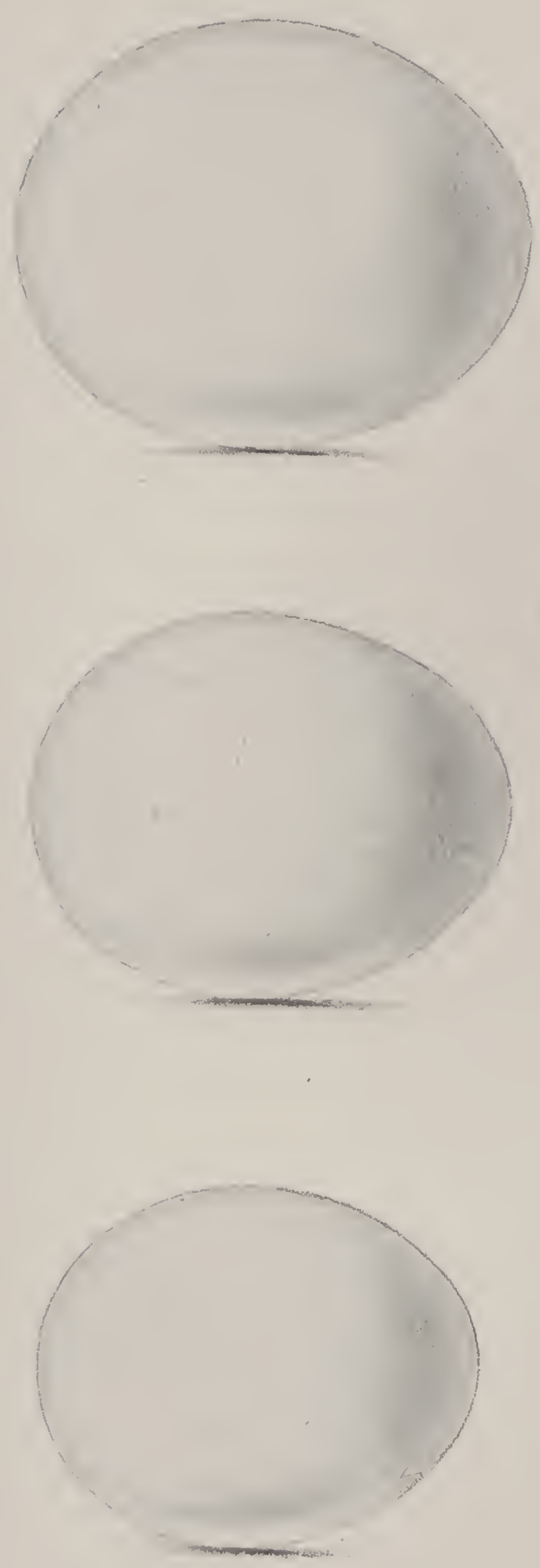

These assertions, when applied to the particular eggs which each of the parties may themselves have seen, are no doubt perfectly correct. Mr. Selby, however, contradicts the statement in the "Index Ornithologicus" of Latham, and says, that they are "white, and not spotted."

With the descriptions of Montagu and Latham, taking them to refer, as I have done, to particular specimens of the eggs of the same species, I have no difficulty in agreeing, and regret that I cannot do so with that of Mr. Selby also. The eggs of the Marsh Harrier, although for the most part white, or slightly tinted with blue, are sometimes also spotted and smeared with brown, in the same manner as those of the hen harrier.

'This species and the common buzzard approximate most beautifully as far as relates to their mode of brceding, and form the connecting link between the genera Buteo and Circus. The common buzzard, as I have before shown, breeds in trees; its eggs are usually spotted, sometimes quite white. The eggs of the Marsh Harrier are most commonly white, but sometimes spotted; it almost always breeds on the ground, but will sometimes, assuming the habits of the common buzzard, breed in the fork of a large tree, in which place Montagu says he has himself found it; in such a situation the nest would, as he describes it, be formed of sticks and such like materials. In the fen-countries, its usual resort, the nest is composed of so large a quantity of flags, reeds, and sedges, as to raise it a foot, or a foot and a half above the ground. The eggs are usually four, sometimes, though not often, five in number; the time of incubation early in May.

All the eggs of the Marsh Harrier which I have seen, upon the identity of which reliance could be placed, are considerably less than those of the common buzzard; 
and many of the eggs which stand in collections as those of the Marsh Harrier, would, I think, more properly bear the name of the other species. It is from one of these that $\mathrm{Mr}$. Yarrell has written his description, when he gives the dimensions as "two inches one line in length, and one inch six lines in breadth." The eggs of the three species of Harrier may be readily known from those of nearly-allied species, by the clear greenishblue of the inside, which may be seen upon holding them to the light. 


\section{HEN HARRIER.}

\section{Circus cyaneus.}

PLATE XVI. FIG. II.

The Hen Harrier breeds chiefly in the marshy districts of this country, and was once common in the fens of Cambridgeshire: when in such low lands, the nest is placed upon the ground, and is formed of so large a quantity of flags, sedge, and reeds, as to raise it eighteen inches or two feet above the surface, and thus to protect the eggs and young ones from the water by which the low grounds are often flooded. A correspondent tells me that he has known the nest raised in this manner nearly four feet from the foundation.

I copy an interesting account of this species by Sir William Jardine, in his edition of "Wilson's Ornitho" logy ;" speaking of the Hen Harrier, he says, "The habits of those in Great Britain differ considerably according to the district they inhabit. In a country possessing a considerable proportion of plain and mountain, where I have had the greatest opportunities of attending to them, they always retire at the commencement of the breeding season to the wildest hills, and during this time not one indiridual will be found in the low country. For several days previous to commencing their nest, the male and female are seen soaring about, as if in search of, or examining, a proper situation; are very noisy, and toy and cuff each other in the air. When the place is fixed 
and the nest completed, the female is left alone, and, when hatching, will not allow the male bird to visit the nest, but, on his approach, rises and drives him with screams to a distance. The nest is made very frequently in a heath-bush by the edge of some ravine, and is composed of sticks with a very slender lining; it is sometimes also formed in one of those places called scars, or where there has been a rush on the side of a steep hill after a mountain thunder shower: here little or no nest is made, and the eggs are merely laid on the bare ground, which has been scraped hollow. In a flat or level country, some common is generally chosen, and the nest is found in a whin or other scrubby bush, sometimes a little way from the ground."

The eggs are four or five in number, and though perhaps most frequently of a spotless bluish-white, are yet often slightly marked with yellowish-brown, mixed with a purplish hue, and in some specimens, with more distinctlydefined spots of light brown. To Mr. Heysham I am indebted for specimens from the neighbourhood of Carlisle; and to the Rev. W. D. Fox, for others from the fens of Cambridge. 


\section{MONTAGU'S HARRIER.}

Circus cineraceus.

PIATE XVI. FIG. III.

For authentic, and, therefore, valuable specimens of the eggs of this species, I am indebted to my friend the Rev. W. D. Fox. 'These were procured for him by Mr. David Baker of Melbourne, who has an accurate knowledge of the birds of the fen-countries, which he stuffs for sale; and that there might be no doubt of their identity, the old birds were trapped upon the nest.

Montagu's Harrier breeds in the fens of Cambridgeshire, and though at one time more abundant than has been supposed, is now becoming extinct, and exceedingly difficult to procure. The nest, which is placed upon the ground, is more slight than those of the other two harriers, and is composed, like them, of flags, sedge and rushes. The eggs are usually four or five in number; the nest, from which the specimens sent me by $\mathrm{Mr}$. Fox were taken, contained six, the only instance of the kind which Mr. Baker has ever met with; they are of a clear white, distinctly tinted with light blue, and are never, to the best of my information, spotted. Like the last species, the time of incubation is early in May.

Mr. Alfred Newton informs me that the Harriers, like the owls, the eagles, and probably all the hawk tribe, begin to sit upon the first egg, and as there is also most likely an interval of some days between the production of each egg, the young are of very different ages, and much more easily supplied with food. 
RAPTORES.

\section{E $\Lambda$ G L E O W L.}

\section{Bubo maximus.}

\section{PLATE XVII, FIG. IV.}

THERE is a strong and perfect similarity amongst the eggs of the different species of owls, which we could scarcely expect to find in the eggs of birds which differ from each other so much in their mode of breeding. The eggs of those species which are deposited in the hollows of old trees and deserted ruins, and those which are found on the bare sod, and exposed to the broad light of day and the pelting storm, are alike without colour. The Eagle Owl breeds in the north of Europe, making its nest upon the bleak and unsheltered summit of some lofty mountain. In such situations Linnæus found their nests and young ones. In his journal for the 17th of May he says, "At a quarter of a mile from the posthouse (at Dingersjö) stands the highest mountain in Medelpad, called Norby Knylen, and being desirous of examining it more minutely I travelled to Norby. After much difficulty and fatigue we reached the summit of the mountain to the westward. We endearoured to descend at the south side, which was the steepest, and where rocks were piled on rocks. We were often obliged to sit down, and in that position to slide for a considerable way. About the middle of this side of the monntain an Eagle Owl started up suddenly before us. Immediately afterwards we perceived a little plot of grass fronting the south, and guarded, as it were, by rocky walls on the east and west, so that no wind but the south could reach it. Here were three young birds and an egg. 
Of these birds one was as large as two fists, the other two were but half as large."

On the 16th of June he found another nest near Old Pithoea, on a steep hill called Brevikberget, and a pair of Eagle Owls, almost full grown but not able to fly. It was not, howerer, our good luck to be alike successful, although we traversed in search of them the pinecrested mountain ridges, the rocky steeps, and the snowclad heights of the neighbouring country. In one instance only we had the gratification of seeing one of these noble birds at large, as it topped the heathery summit of the hill which we were climbing, and was lost to our anxious gaze.

Mr. Wolley, whose ardent love for natural history has led him to follow in the footsteps of Linnæus, and to explore the wilds of the north of Sweden, has been more successful than we were, as the following very interesting: and graphic account will show. It is written from Haparanda.

He expresses the great difficulty, which we also fully experienced in Norway, of "hunting up the ornithological population of such a country," where the birds are few, and the area over which they are scattered vast and almost inaccessible; he writes, "First I was determined to find a nest of Strix bubo; many expeditions of some miles, and several days lost, have resulted in the finding of a single nest with two young ones and an egg just hatching, and this after inquiries at every place I have been to. It was on the 20th of May, and after climbing to the mysterious cave of Skulberg, that our road lay under a steep mountain-side broken up into crags and ledges of the character which is usually so attractive to birds of prey. There was a little village at the foot, and an old man pointed out the direction from which the 
hootings were to be heard every evening. Whilst I was listening to the consultation, and taking a survey with my glass, an osprey flew along the edge of the cliff, and at a great height above us, and mellowed in the distance there came a full note from a Berg-ufo who no doubt had seen the stranger bird. This was very encouraging, and it did not take long to arrange the order in which the various likely rocks were to be visited. An actire woodman accompanied me axe in hand. When we were fairly in the cliffs we came to a point where some large bird was in the habit of sitting to tear its prey, and feathers, and white feet of hares were lying about. A great owl flew below us, showing a beautiful expanse of back and wings, and as we proceeded in the direction from which it came another large owl rose from the face of the cliff, flew a hundred paces forward, turned its wide face towards us, and came a short distance back. I stopped to examine it with my glass to be quite certain it was $\mathrm{S}$. bubo. Satisfied on this point, we only had to walk a few paces along a ledge before the family group was in sight: two blind little puffs covered with down just tinged with yellow, and an egg with the prisoner inside uttering his series of four or five chirps through the window he had made in the shell, with a roice scarcely more feeble than that of his elder brothers. There did not seem to be much difference in the ages of the three; they were lying upon a small quantity of compressed fur, principally of rats, the remains of the castings of the parent birds, their bed nearly flat, for there was not more than two inches of soil. Uva-ursi and several other plants grew near, and a small Scotch fir-tree had its trunk curiously flattened to the perpendicular rock at the back; the ledge was not more than two feet wide, and terminated abruptly just beyond the nest; the rock beneath was also perpen- 
dicular. A party of village ladies watching us from below were very successful in imitating the owls, but the owls. themselves would not answer. We waited at the nest a long time in the hope that they would show themselves: but it was not till we had left it that we saw them again sitting on the topmost shoots of spruce fir's with their ears finely relieved against the sky, and as we were nearly in the rillage again they hooted with a troubled note. I have risited three other sites of nests of this bird, and they were all of similar character upon ledges in or orer cliffs. They were all unsheltered overhead. Sunshine seems to be rather courted than avoided. This season is a week or fortnight later than usual."

Mr. J. H. Gurney has thrice recorded in the "Zoologist" the interesting fact that a pair of Eagle Owls, the property of $\mathrm{Mr}$. Fountaine, have for three successive years laid their eggs and reared their young ones in confinement. The eggs were in every instance three in number; and as Mr. Gurney remarks, "it may be safely assumed to be the normal number of eggs produced by this species," especially since the nest found by Mr. Wolley confirms the assumption. One of the nests found by Linnæus contained three young ones and a rotten egg. The first egg of the first year "was observed on the 13th of April, and the two others about a week afterwards; two young ones were found to be hatched on the 19th, and the other on the 22nd of May." How very nearly this corresponds with Mr. Wolley's discovery; two of his young ones were newly hatched when he found them on the 20th of May. 'The first egg of the two following years mentioned by Mr. Gurney, was laid so early as the 10th of March. The period of incubation, reckoning from the laying of the first egg to the hatching of the first young one, was in each case thirty-six days. 
RAPTORES.

\title{
SCOPS-EARED OWL.
}

\author{
Scops aLdRovandi.
}

PLATE XIX. FIG. I.

'THIs very minute and beautiful species of owl has been excluded by Mr. Gould from the list of our British birds, although there are several undoubted instances of its having been captured in this country. It has even been said to breed in the county of Durham, in Castle Eden dean, but upon quite insufficient authority. On the Continent, in some parts of France and Italy, it is not uncommon, and lays its eggs, which are four or five in number, in the holes of trees. 
XIX.
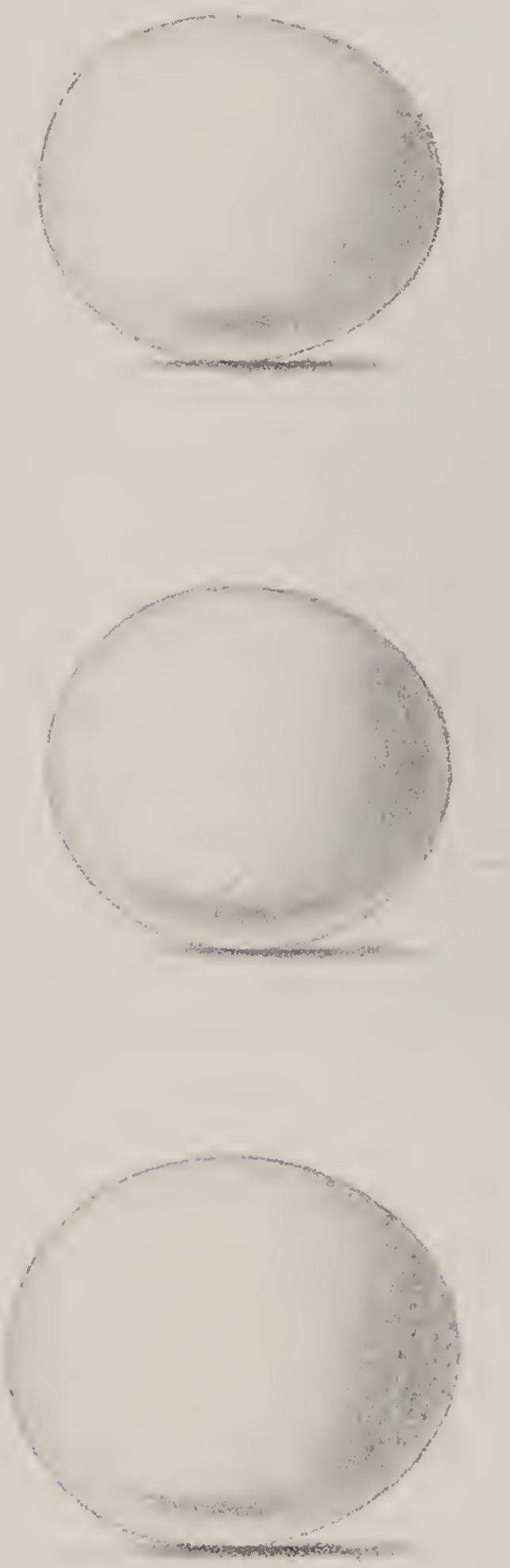



\section{LONG-EARED OWI.}

\section{Otus Vulgaris.}

PLATE XVII. FIG. III.

The Long-eared OWL is to be met with in most of our woody districts, especially those which are composed of fir-trees. I was favoured, during the progress of my former work, with some notes of this species by $\mathrm{Mr}$. J. H. Tuke, but as he has since given a more detailed account in the "Zoologist," I prefer to copy it; he says,"This handsome species is rather generally distributed through the fir woods within six or seven miles around York, taking possession about the middle or end of March of the deserted nest of the crow, ringdove, and perhaps that of the squirrel, in a Scotch or spruce firtree, on which, after flattening and sometimes lining with a few feathers, are deposited its two or three beautifully white eggs. Out of six or seven instances we have never met with more than three eggs or young ones, and in most cases only two. It is curious to observe how flat they invariably make their nests, so much so, that in even a slight wind it is difficult to conceive how the eggs retain their position when the parent bird leaves them.

"This species does not seem to confine its flight entirely to the darker hours, nor its taste very strictly to the mouse tribe, as we have met them in the woods sailing quietly along as if hawking, on a bright sunny day, 
and invariably found in or around the nest, feathers and other remains of the winged race; in one case a freshly-killed chaffinch, in another the wing of a snipe, and several smaller birds, and in a pellet the indigestible pad of a young hare or rabbit.

"A nest which I examined this day, April 11th, contained three eggs, which were laid on what appeared to have been the drey of the squirrel in a tall spruce-fir; this nest was lined with a few feathers, and only discovered on the 31 st of March, and had then the same number of eggs. I hope to ascertain, when the young ones are hatched, whether, as is I believe generally the case with this tribe, the parent bird had commenced incubation when the first egg was laid."

Mr. Tuke thinks that in some of the nests mentioned there could not be less than eight or ten days' difference in the age of the young ones, so that some days must intervene between the production of each egg, the female beginning to sit as soon as the first eggs are laid,--a provision which would enable the old birds the more readily to supply the demands of their voracious progeny.

Mr. Alfred Newton, writing from Elveden Hall, in Norfolk, says, - "The Long-eared is the most plentiful species of owl hereabout, and there are few plantations of any size which do not contain a pair, as far as my own experience goes, though it is opposed to Messis. Tuke's opinion, quoted in your former edition. I should say that the usual number of eggs laid by this owl is four ; this year the gamekeeper has found a nest with five eggs, and my brother has seen six young ones in the same nest. The Long-eared Owl usually adapts a squirrel's nest, called hereabouts a drail, to its own purposes. It appears to feed much on small birds. I have found wheat-ear's, willow-wrens, and chaffinches, or at least their 
remains, in its nest as often as not. I think it delays the act of incubation until its clutch of eggs is completed."

Wilson says, "About six or seven miles below Philadelphia, and not far from the Delarvare, is a low swamp thickly corered with trees, and inundated great part of the year. This place is the resort of great numbers of the qua-bird, or night-raren (Ardea Nycticorax), where they build in large companies. On the 25th of April, while wading among the dark recesses of this place observing the habits of these birds, I discovered a Longeared Owl which had taken possession of one of their nests, and was sitting. On mounting to the nest I found it contained four eggs, and breaking one of these the young appeared almost ready to leave the shell. There were numbers of the qua-birds' nests on the adjoining trees all around, and one of them actually on the same tree." 


\section{SHORT EARED OWL.}

\section{Otus BRACHYoTos.}

PLATE XVII. FIG. II.

The Short-Eared Owh, departing from the habits of the rest of the genus, rears its young ones on the ground; it forms, also, in its mode of breeding, as it does in its flight and general appearance, one of the connecting links between the Falconidie and the owls. Although they for the most part go further north to breed, a fer of them remain upon the moors of Northumberland, where Mr. Charlion of Hesleyside informs me he has frequently found their eggs amongst the heath in his own neighbourhood. Mr. R. R. Wingate has also met with the young ones on the same moors before they were able to fly.

'The Rev. George Low, in his Fauna Orcadensis, says that in his time this owl was very frequent on the hill of Hoy, where it built its nest amongst the heath, and was so impudent during the breeding-season as to take up chickens from the door, and chase pigeons in daylight. In a nest which he found were the remains of a moorfowl and two plovers; it was placed in a large heath-bush, was made without any art, and intolerably fœtid.

The following notes relating to this species are from Sir William Jardine's edition of "Wilson's Ornithology."

"In England it bear's the name of Woodcock Owl, from its appearance nearly about the same time with that 
bird, and re-appearance again in the spring; very few, if any, remain during the whole season, and they are only met with in their migrations to and from the north, their breeding places, similar to the appearance, for a few days, of the ringouzels and dotterels; in spring singly or in pairs, and in the fall in small groups, the amount of their broods when again retiring.

"It is only in the north of England, and over Scotland, that they will rank as summer visitants. Hoy and the other Hebrides where they were first discovered to breed, were considered the southern limit of their incubation. It extends, however, much farther, and may be, perhaps, stated as the extensive muirland ranges of Cumberland, Westmoreland, and Northumberland. Over all the Scottish muirs it occurs in considerable abundance; there are few sportsmen who are unacquainted with it; many are killed during the grouse season, and those individuals which Mr. Selby mentions as found on upland moors I have no doubt bred there.

"On the extensive moors at the Head of Dryfe, a small rivulet in Dumfriesshire, I have for many years past met with one or two pairs of these birds, and the accidental discovery of their young first turned my attention to the range of their breeding; for previous to this, I also held the opinion that they had commenced their nigration southward. The young was discovered by one of my dogs pointing it, and in the following year, by searching at the proper season, two nests were found with five eggs. They were found upon the ground among the heath, the bottom of the nest scraped until the fresh earth appeared, on which the eggs were placed, without any lining or other accessory covering. When approaching the nest or young, the old birds fly and horer round, uttering a shrill cry, and snapping with their bills; they 
will then alight at a short distance, survey the aggressor, and again resume their flight and cries. The young are barely able to fly by the 12th of August, and appear to leave the nest some time before they are able to rise from the ground. I have taken them, on that great day to sportsmen, squatted on the heath like young black game, at no great distance from each other, and always attended by the parent birds. Last year (1831) I found them in their old haunts, to which they appear to return very regularly."

Mr. Hoy, in a communication in "Loudon's Magazine," says, "I am acquainted with two localities in the scuthwestern part of Norfolk, where pairs of this bird breed, and I have known several instances of their eggs and young being found. One situation is on a dry heathy soil, the nest placed on the ground amongst high heath, the other in low fenny ground, among sedge and rushes."

Mr. Alfred Newton tells me that this species used to breed yearly in the fens of West Norfolk; he says,- "I have also heard of nests in the uplands, and though I doubt not that it still breeds occasionally in places which are sufficiently rough with sedge or heather, yet I have not heard of a nest within the last few years in this neighbourhood."

These observations have a twofold interest, and show that this species does not confine itself in England to the north, or its breeding place to the highland heathery moors. 
XVII

I

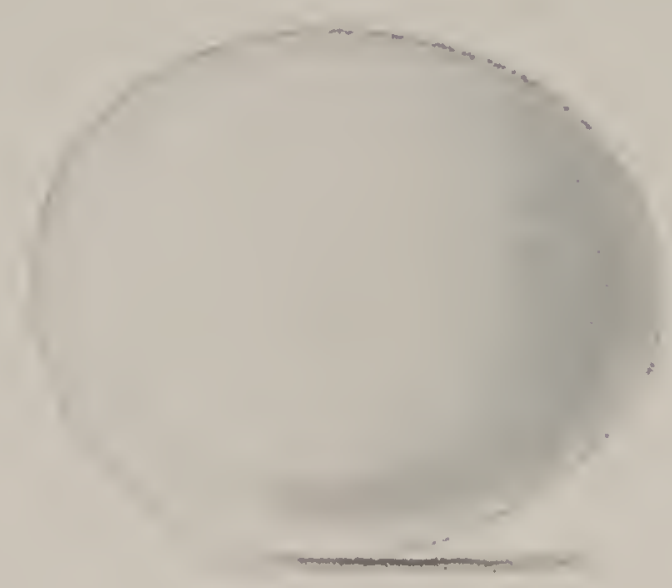

:

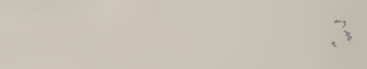

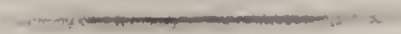

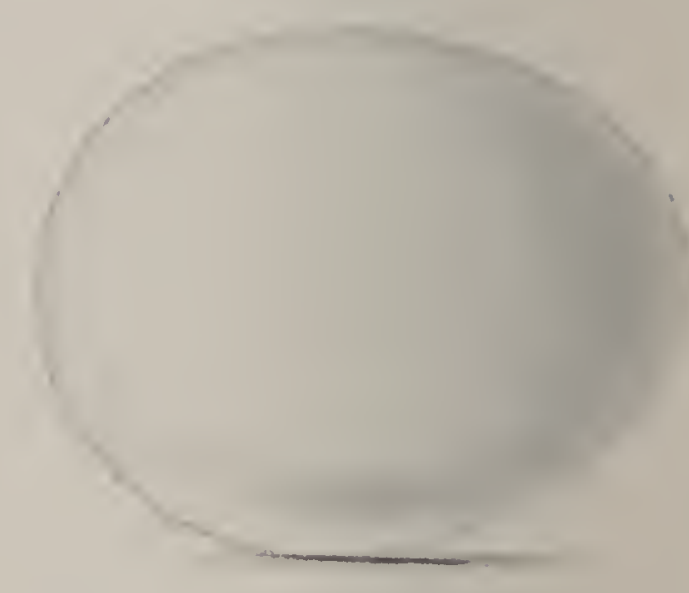

t.

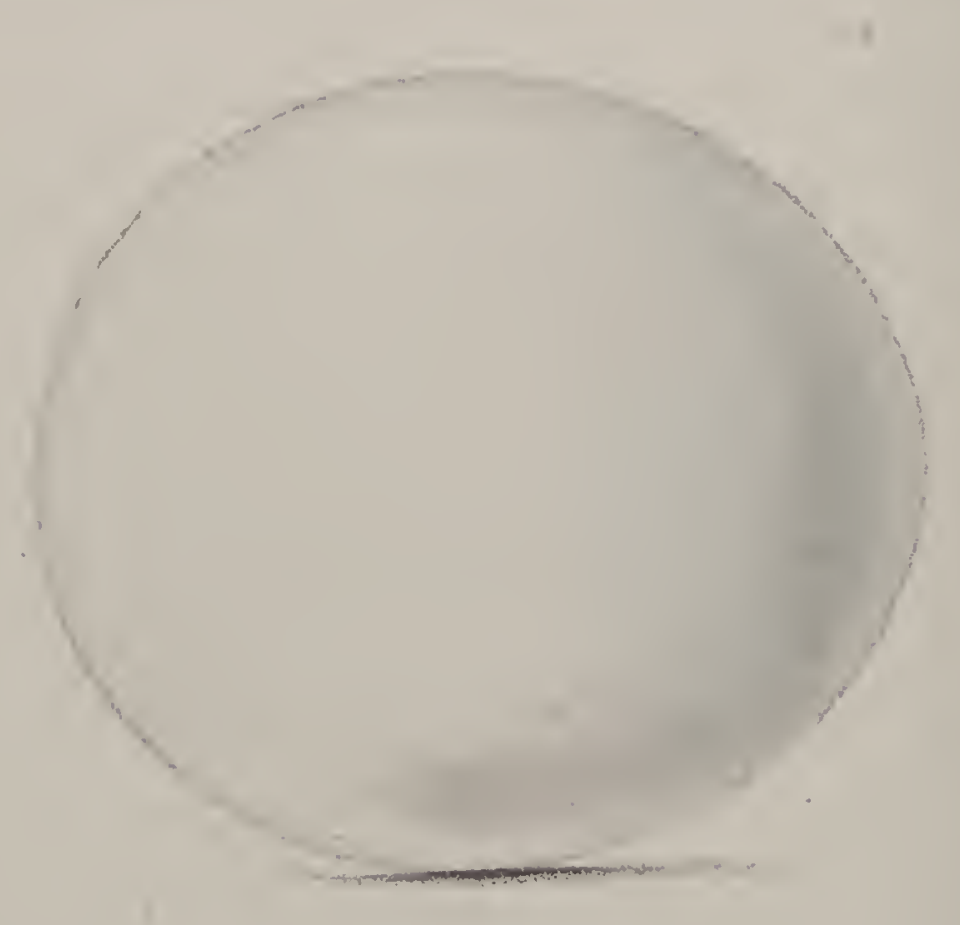


WHITE OWL, BARN, OR SCREECH-OWL.

\author{
STRIX FLAMMEA.
}

PLATE XVII, FIG. I.

Although the White Owl breeds with others of the tribe early in the season, it seems in some cases to prolong the pleasures of incubation to a much longer period than is enjoyed by other birds. Mr. Blyth mentions a very curious instance of this. "A nest of the barn owl last summer in this neighbourhood (Tooting) contained two eggs, and when these were hatched two more were laid, which latter were probably hatched by the warmth of the young birds. A third laying took place after the latter were hatched, and the nest at last contained six young owls of three different ages, which were all reared."

This confirms the supposition which I ventured when speaking of the long-eared owl, that the owls do not deposit their eggs as other birds for the most part do, in regular daily succession.

This owl breeds in old ruins, under the eaves and in the steeples of churches - and may be found in York Minster-in deserted dove-cotes, in bárns, and also in the holes of trees, and lays from three to five eggs. A nest which the Messrs. Tuke found near York contained six eggs; and it is rather curious that a nest and eggs of the starling were in the same tree close below it. The 
White Owl probably lives chiefly upon mice, but is known also to destroy small birds.

The long-eared owl will destroy birds as large as the blackbird; how, then, can we account for the immunity of the starling?

From what information we have on the subject, it appears that the different species of owls, and sometimes the same species, evince very great irregularity in their time of breeding, the date varying from the laying of the first egg on the 10th of March by the eagle owl, to the production of the young of the snowy and short-eared owls in the month of August. 


\section{TAWNY OWL, WOOD OWL.}

\section{Syrnium stridula.}

PLATE XVIII. FIG. II.

The Tawny Owl usually lays its eggs in a hollow tree, sometimes in the holes of rocks, and occasionally in the deserted nest of some other bird; they are round, large, bright, and glossy, from three to five in number, and are deposited at irregular intervals, the first being sat upon as soon as laid; the young of the same nest differ in consequence very considerably in their size.

This is the owl from which issues forth that loud melancholy sound at night, which, however much it may be associated with goblins in the minds of others, is extremely agreeable to the ear that is fond of nature's sylvan sounds.

Mr. Alfred Newton says, "a pair which annually breed near this house do not always begin the work of incubation until they have laid their complement of four eggs, but I have never been able to account for their habits being irregular in this particular." 


\title{
S NOWY OWL.
}

\author{
Surnia nyctea. \\ PLATE XVIII. FIG. III.
}

The Snowy OwL which, it is supposed, used to breed on some of the Shetland Islands, is now a very rare visitor to any part of Britain. It is said to breed on various parts of the European Continent, and has been met with in most of those countries washed by the icy seas. The egg, from which I have made my drawing, is in the collection of Mr. Wilmot and was brought from Labrador.

Mr. Macgillivray quotes a letter from Dr. Edmondston relative to this species, in which he says, "I have always doubted whether it bred here. Presumptions were in favour of the affirmative, but actual proof was wanting. 1 have been lately informed that its nest was found two years ago, in August, in a low rocky ledge not far from here. The young, three in number, fully fledged, were of a brown colour sprinlsled with gray." This letter was written from Dr. Edmonston's residence at Balta Sound, in Unst, the most northerly of the Shetland Islands.

Other eggs in the collection of Mr. Walter which were laid in confinement are considerably larger. I am glad to find that all the owls' eggs which I have drawn correspond in size with those figured by Thienemann. 

XVIII
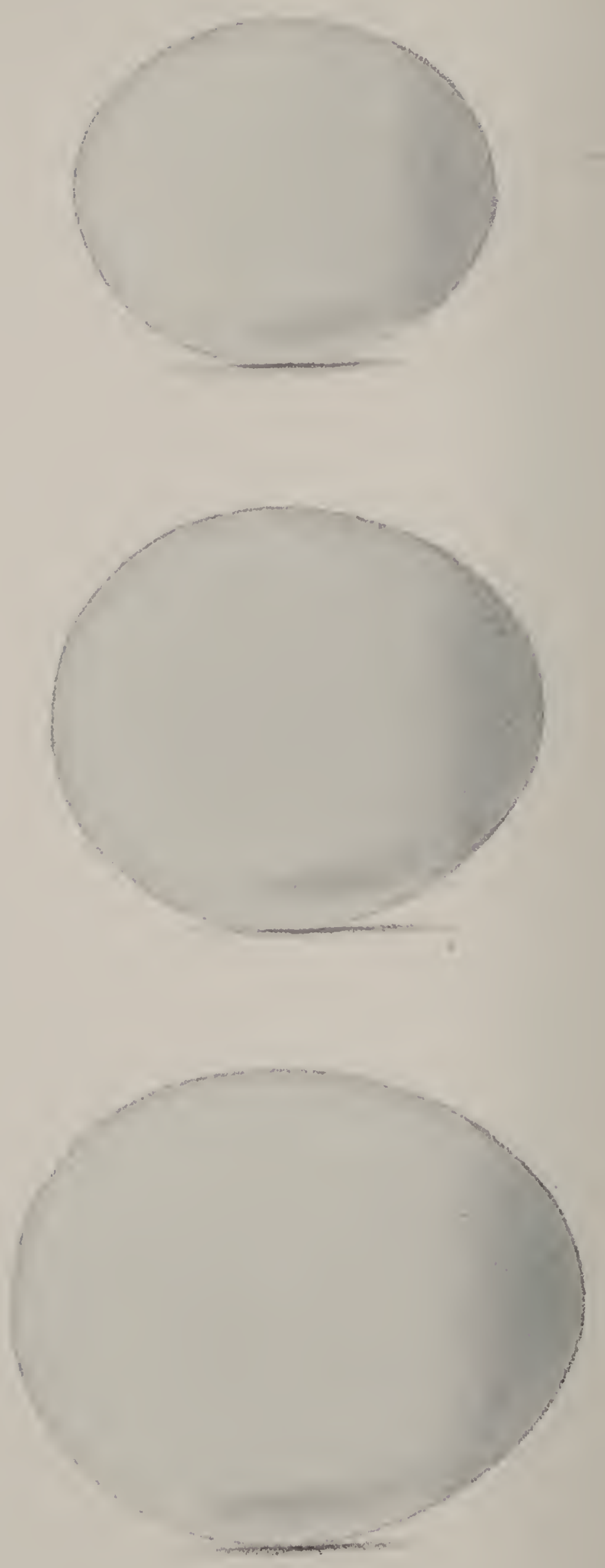


\section{HAWK OWL.}

\section{Surnia Funerea.}

PLATE XVIII, FIG. I.

Mr. Yarrell has figured this species as a British bird, one having been captured on board ship off the coast of Cornwall; he makes the following remarks, of which I avail myself. "When we consider that this bird is an inhabitant of Denmark, Norway, Sweden, and other parts of the north of Europe, that it is not unfrequently seen in Germany, and even in France, it is a matter of surprise that it should not have been taken in this country before."

The Hawk Owl is said to build its nest in trees, and to lay two eggs; for the one now figured I am indebted to the kindness of Mr. Walter; it agrees in size with the one figured by 'Thienemann. 


\section{TENGMALM'S OWL.}

\section{Noctud Tengmalmi.}

PLATE XIX. FIG. II.

WE have no satisfactory information with regard to the habits of this little owl during the brecding-season.

It is common throughout the northern countries of Europe, inhabiting thick and extensive pine forests. In North America it has, according to Dr. Richardson, a wide range, embracing all the woody country from the Great Slave Lake to the United States. It most probably breeds, like the preceding species, in the holes of trees. 


\section{LITTLE OWL.}

\section{Noctua nudipes (Nilsson).}

PLATE XIX. FIG. III.

So little is known regarding the habits of the three species of small owls, which are only periodical and rare visitor's to our shores, that I feel much indebted to the late Mr. Hoy for the following information regarding the present species, as well as for specimens of its eggs.

The Little Owl is, like the rest of the family, an early breeder. It not unfrequently makes its nest in the holes of trees; old ruins, however, and the towers of churches are its favourite resort. It appears to be of a quarrelsome disposition, two pairs being rarely met with as near neighbours during the breeding-season.

The eggs are usually four, sometimes five in number, and vary a little in size as well as contour.

The Little Owl makes no nest, although an accumulation of rubbish arising from its castings may be frequently found in the hole, which is often made use of for a long time previous to incubation.

In addition to the several instances of its appearance in this country, enumerated by Mr. Yarrell, I may add, on the authority of Mr. J. J. Briggs, of Melbourn, Derbyshire, that a specimen of the Little Owl was taken in that county, and exhibited alive during the last spring.

$\mathrm{Mr}$. Gurney makes the following announcement in the "Zoologist." "A pair of passerine owls which I had in 
confinement nested this spring in a small covered box, which was placed in a corner of their cage. They laid four eggs about the middle of the month of May, two of which they soon broke, but hatched the other two early in June. The two young ones did not long survive: how they disappeared I am unable to say, and am almost disposed to think the old birds must have devoured them. I regret, owing to the nest being placed in a covered box, I was unable correctly to ascertain the period of incubation."

I believe with Mr. Gould that this is not the Strix passerina of Linnæus, and have therefore followed him in adopting Nilsson's name of nudipes. 

$X X$
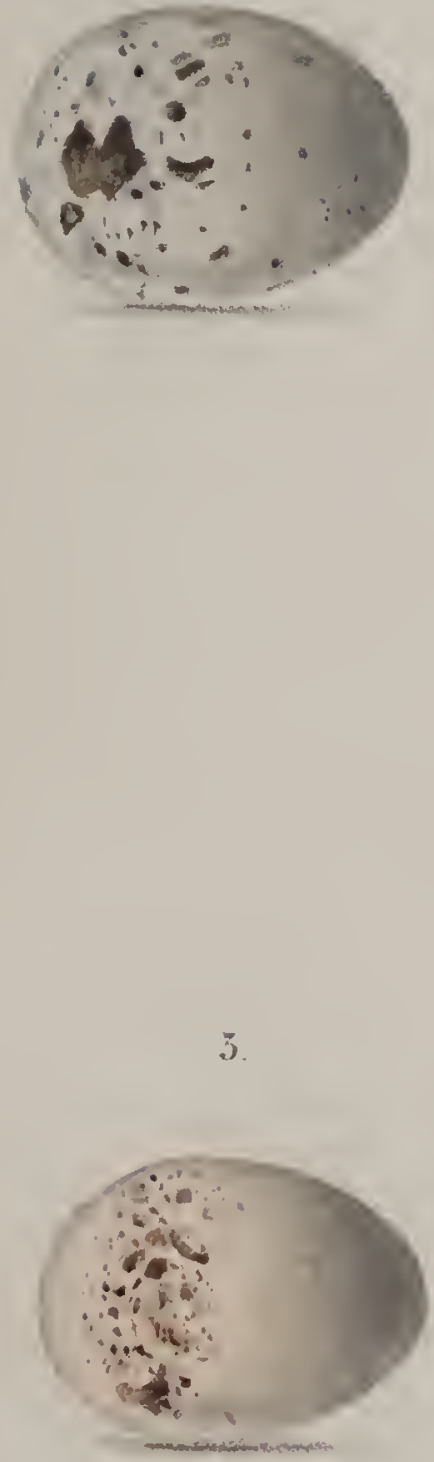

I

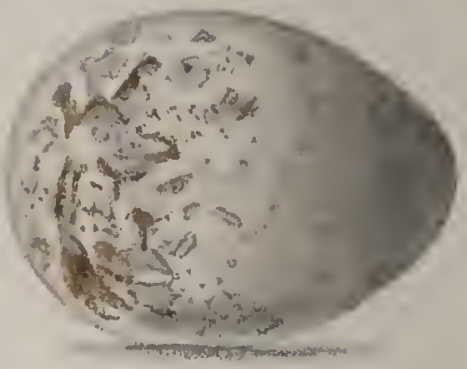

4.

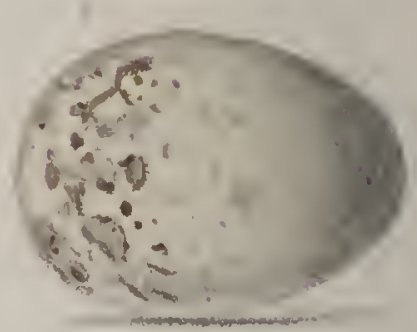




\section{GREAT GREY SHRIKE.}

\section{Lanius Excubitor.}

PLATE XX. FIG. I.

THE eggs of the three British species of Shrike form a very beautiful and isolated group, as different from those of other birds as they are like each other.

Like our well known species the red-backed shrike, this bird makes its nest in thick bushes and high hedges; it is large, and composed of the stalks of umbelliferous plants, roots, moss, and wool, lined with finer roots and dry grass. The eggs are four or five, and it is said sometimes six or seven in number; though differing a good deal in the frequency of the spots, they still preserve more or less the constant characteristic zone. In colour they are more sombre than those of the succeeding species; and none of the specimens I have seen are ornamented with any of their rich variety of tints. 
INCESSORES.

LA.VIADE.

DENTIROSTRES.

RED-BACKED SHRIKE, BUTCHER BIRD.

\section{Lanius COLlurio.}

PLATE XX. FIGS. III. AND IV.

THE nest of the Red-backed Shrike is built in a thick thorn-hedge, or single bush; one which I have observed during the past summer was in a thorn-tree, at an elevation of ten or twelve feet; it is unusually large, and is composed of a quantity of coarse materials; the outside is formed of the stalks of umbelliferous plants, succeeded by moss and fine grass, with a small portion of wool, and is lined with slender roots, interspersed with a few hairs. The eggs are four or five in number, and are amongst the most beautiful of those of our British birds. Figure four of the plate represents the usual colouring, in which variety they closely resemble those of the other two species; the other figure is from an egg which $I$ took at school, and have never since seen equalled. The zone of spots is sometimes at the narrow end of the egg.

Doubts have been expressed whether or not the Redbacked Shrike has deserved the name of Lanius, or butcher, which has been bestowed upon it.

I have pleasure in giving my testimony as to its well merited possession of the title. Whilst riding through one of the well-fenced lanes of Suffolk I observed one of these birds, a male, conspicuous from its bright plumage, busily engaged with something in the hedge, 
from which it seemed very reluctant to be driven by my approach. On examining the spot I found, very much to my satisfaction, a small bird, of what species I did not at the time note, so firmly spitted on a blunt thorn that it must have required considerable force to fix it there; it was in a state of perfect nudity, every feather had been plucked from it, and its head torn off. 
INCESSORES.

LANIADA.

DENTIROSTRES.

\section{WOODCHAT SHRIKE.}

\section{LANius RUFus.}

PLATE XX. FIG. II.

Naturalists, especially those who take an interest in that portion of Ornithology which the present pages are intended to illustrate, have lost a most ardent and successful coadjutor by the death of $\mathrm{Mr}$. Hoy; I have greatly to regret his loss, for had he been yet living I should have been enabled, as will be seen from the frequent quotations from his information in my former work, to have given much more that would have been new and interesting during the progress of the present.

He says of the Woodchat, that "it differs from Lanius collurio in the choice of a situation for its nest, placing it invariably on trees, and preferring the oak. The nest is fixed in the fork of a projecting branch, and is composed on the outside of sticlss and wool, mixed with white moss from the bodies of the trees, and lined with fine grass and wool. Eggs, four or five in number, rather smaller than those of the red-backed shrike, and varying much in markings, the ground colour being pale blue in some, in others a dirty white, surrounded near the larger end with a zone of rust-coloured spots; in some again the markings and spots are of a paler colour, and more dispersed over the egg. It is not a wild bird, building close to houses and public roads. It is abundant in some parts of the Netherlands, and 
arrives and departs about the same time as the Lanius collurio."

It is one of the very few birds which greet the eye of the traveller as he passes through the German States. I remember to have seen several during a ride through Wirtemburg, and the Duchy of Baden, amongst the fruittrees which mark the line of road.

It will be seen that the egg from which the drawing is made, is rather larger than those of the L. collurio, but they differ a good deal in size as well as colour.

I have a remarkable variety from the collection of the Messis. Tuke; the spots, which are large and deep in colour, of brown and neutral tint, are scattered equally over the whole surface, and like the figure of the plate, depart somewhat from the generic character. 
INCESSORES.

MUSCICAPIDA.

DENTIROSTRES.

SPO'TTED FLYCA'THER.

MUSCICAPA GRISOLA.

PLATE XXI. FIG. I.

The Spotted Flycatcher makes its nest about the beginning of June; it is built in the hole of a wall, or of a decayed tree stump, on the low branches and amongst the exposed roots of trees which overhang a stream of water, and upon the boughs of wall fruit-trees; these are its most usual and natural places of resort, but there is scarcely any place so whimsical as not to be chosen by it for the position of its nest; it has been twice detected breeding on the lamp-posts in the crowded streets; one of these instances is mentioned by Mr. Jesse, in his "Gleanings of Natural History."

The nest is formed of small twigs, roots, and moss, interwoven with spider's' webs, and is lined with hair and feathers.

The eggs are four or five in number, and are not subject to much variety in colour; in form they are some. times longer and more pointed than the plate.

I have stated that the genera of our British birds might, with a few exceptions, be determined by the colouring of their eggs alone, and have mentioned among those exceptions the eggs of our two flycatchers, which usually differ as much from each other as they do from those of the most remote species. It was, therefore, with very peculiar interest that I have since seen eggs of the Spotted Flycatcher of a clear spotless blue in the collections of Mr. Wilmot and of Mr. Salmon. 
XXI.
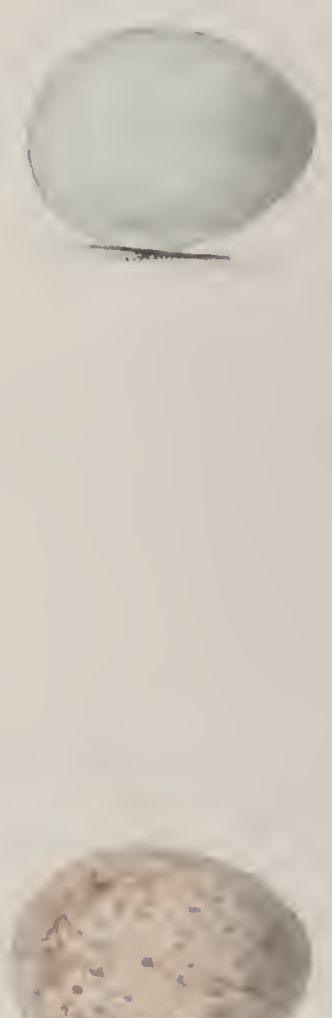

INCESSORES.

MUSCICAPIDAE.

DENTIROSTRES

\section{PIED FLYCATCHER.}

\section{Muscicapa atricapilla.}

PLATE XXI. FIG. II.

Although a few stragglers have been met with in various parts of England (Bewick mentions a nest which was found in Axwell Park, near Newcastle-upon-Tyne; and Bolton found some in the West Riding of Yorkshire), Westmoreland and Cumberland are the favourite resorts of this species, and especially that portion of those counties which forms the choicest of England's scenery, the lake district. Here, also, it is quite local, and though I have seen it in plenty in the woods which form the beautiful banks of the rivers Eamont and Lowther, and upon the Eden at Eden-hall, yet during a walk through the lake district it never appeared again, except upon the borders of Ullswater. Mr. Heppenstall, a correspondent of the "Zoologist," states "that it is rather plentiful in Wharncliffe Wood, not far from Sheffield, that it is exceedingly local, only being found in a space of fifty or sixty acres of venerable oak-trees near some fish-ponds."

Mr. Blackwall has recorded a very interesting instance in which a pair of Pied Flycatchers, imitating the more familiar habits of the other species, took up their residence, and "for a long series of years incubated their cggs, and nurtured their young in security, in a small aperture close by the portico to the principal entrance of" his father's residence in Denbighshire, "undisturbed appa- 
rently by the frequent passing and repassing of its inmates," until they were driven out by a swarm of bees, which took possession of the hole.

To a friend and schoolfellow, Mr. John Gibson, who resided at Tyrril, near Penrith, and for some years observed the habits of this bird, I am indebted for the following information, accompanied with the nests and eggs.

The Pied Flycatcher builds its nest about the end of May, or beginning of June, in the holes of trees, walls, and bridges, and appears particularly partial to the neighbourhood of a stream of water. The hole chosen is generally too small to admit the hand, and the nest rarely at the depth of more than four or five inches; it is slight, and composed of small quantities of dried grass and straws, lined with very fine grass and hairs, with occasionally a few dead leaves. It usually lays from four to six eggs, but Mr. Heysham, who meets with them near Carlisle, and has published some interesting papers relative to their nidification, \&c., informs me that the Pied Flycatcher frequently lays seven or eight eggs, several instances of each having come under his observation during the spring of 1831, that the eggs also differ considerably in size and conformation, those contained in one rest that he took being unusually small, nearly oval, and almost white; he has found the nest two successive years in the stump of a felled tree. 
$\leftrightarrow$ 
XXII

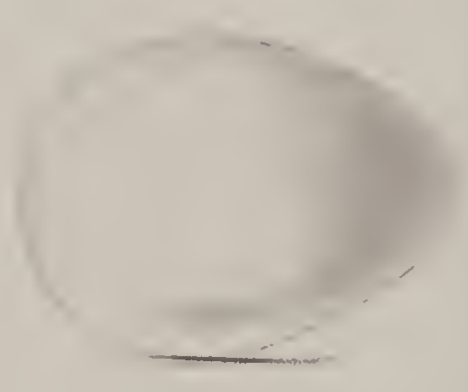




\section{COMMON DIPPER, WATER OUZEL.}

\section{Cinclus aquaticus.}

PLATE XXII.

Is its nidification, as well as its general appearance, the Water Ouzel closely resembles our common wren. It is an active and lively little bird, and seems to attach itself to those mountain streams, the currents of which are rapid and often broken; there it may be seen, either flying past you with great rapidity, or seated upon some stone in the middle of the stream, warbling its sweet notes, when all around it is cold and ice-bound. It begins to prepare its nest early in April; it is, as before mentioned, very similar to that of the common wren; like it, it is composed of an abundance of moss, thickly and compactly woven together, and threaded through here and there by a few straws to give it greater strength; it is covered with a dome, leaving merely the small hole of entrance for the bird. This little doorway is, too, as I have seldom failed to notice in the nest of the wren, neatly smoothed down and kept straight and even, for the reception of the bird's feet in passing in and out, by a few strong grass stalks; it is not so deep inside as other nests of a similar formation, being very thickly lined with a large quantity of dead leaves of the beech and oak, but chiefly of the latter, with a few straws and flags; it is placed, for the most part, either against the bank of a river, or the moss-grown surface of a rock. 
My friend Mr. Benjamin Johnson has known of a nest of this bird for many years in succession, which was built upon the rafters in one of the salmon fish-lochs upon the river Tyne. It has been repeatedly known to build its nest under the arch formed by a natural waterfall or milldam, and within reach of the passing spray. The eggs are four or five in number, white when blown, but of a delicate pink when the yolk is yet in them.

Once, when in company with Mr. George Selby, in the beautiful grounds of Twizell, we came suddenly upon a nest full of young dippers, which, though scarcely able to fly, instantly scrambled into the water, down the stream of which they were hurried with such rapidity that I supposed it impossible that any of them could have escaped destruction; they did so, however, and landed safely far below. 

XXIII
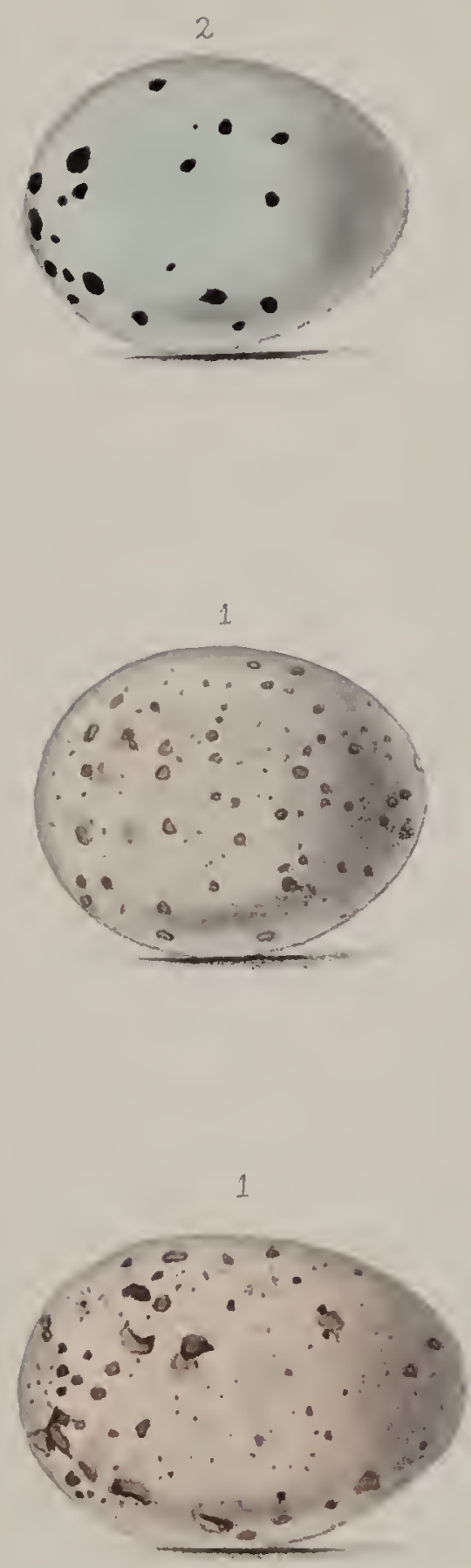


\section{MISSEL THRUSH.}

\section{Turdus viscivorus.}

PLATE XXIII. FIG. I.

The Missel Thrush, at all other times a very shy and wary bird, seen only at a distance, or heard pouring forth its peculiarly wild, full note from the top of some high tree, becomes quite familiar in the spring, approaches our orchards and gardens, and makes its nest, which resembles that of the blackbird, about the middle of March, in plantations of fir or in single trees of oak, apple, \&c., placing it usually at the first divarication of the branches, ten or fifteen feet above the ground. I know of no bird that seems at times to have so little idea of concealing its nest as the Missel Thrush; it is sometimes scarcely possible to pass by it withont discovery; it is formed of large quantities of straw, matting stolen from the garden, wool, and grass, which are frequently left dangling down on all sides, as though the nest had been torn to pieces; a little moss is sometimes used; it is then cemented with mud, and afterwards lined with fine dry grass. I have seen a nest of this bird the foundation of which was mud, strongly cemented to, and nearly encircling, the branches between which it was placed.

The female lays four or five eggs, differing a good deal in size as well as in the ground colour, which varies from a greenish to a reddish tint; they are always easily known from the eggs of any other bird. 
I had always believed that the Missel Thrush deserved the character which it has obtained of quarrelsomeness and pugnacity, until I have become better acquainted with its history. Wherever its nest is there its harsh querulous cries may be often heard. During the breeding season it is the most persecuted bird that lives. It is kept in perpetual turmoil, and, well for it, it is possessed with courage. Its egg's are constantly sucked by the jackdaw and the corby crow, and if it should succeed in defending them by its intrepidity till they are hatched, its young are the epicure's bit of the same crow and jackdaw, and even tempt the rook to become raptorial. When I saw the Missel Thrushes making their nests here, as they do every year, high up, forty or fifty feet above the ground, and midway upon the horizontal branches ol' some lofty cedar-trees, I thought how securely they were placed, and so they were from terrestrial foes; but, called out as a witness to the murder by the pitiless cries of the poor persecuted thrushes, I have had the mortification of seeing their young ones carried off year after year with a loud croak of satisfaction by their demon foe the corby crow. Out of a dozen nests which I have noticed upon these trees, the young from two only have escaped.

Mr. Bond says that he has known the Missel Thrush to again lay its eggs in the same nest in which it had successfully reared a brood of young ones. 


\section{Turdus musicus.}

PLATE XXII. FIG. II.

THE nest of the thrush is composed of moss and dry grass, with the addition of a few sticks, straw, and roots, cemented together in the inside by a composition of clay and rotten wood.

Nearly all our writers on the subject state, that the nest of the thrush is plastered with cow-dung; I am very much inclined to think that they are mistaken, and that if the material is ever used, it is in very rare instances only. Amongst a large number of the nests which I have examined, when the plaster was yet freshly spread, there did not appear to be anything besides clay, in which was mixed up small bits of rotten wood, forming together, when dry, a composition which in many instances is completely water-tight. When the spring has been a wet one I lave frequently found the newly-finished nests half full of water, either causing their abandonment by the birds, or delaying them some days from laying their eggs. In a few nests I have noticed particles of reeds and thistle-down mixed with the clay instead of rotten wood.

In the south of England the 'Thrush begins to build early in March. In the north it is much later.

In Westmoreland, where with a party of my schoolfellows I spent all my play hours in hunting birds' nests, cach of us being on the alert and anxious to find 
the first of the season, we never met with the eggs of the thrush earlier than the beginning of April, and for several years the first nest and eggs were taken between the 5 th and 8th of the month.

The situation where we used to find them raried much. In thick thorn or holly bushes, tall furze or branbles, the top of a dead stake-fence, or amongst the exposed roots of trees on a bank side; they are also frequently built in gardens on fruit-trees against a wall. Here, in Surrey, where evergreens abound, they are glad to make use of the early shelter of the laurel, and two or three pairs every year make their nests high up upon the horizontal branches of some large cedars. Mr. J. H. Gurney says, that "a Song Thrush in a plantation at Sprowston, near Norwich, instead of making her nest in the ordinary manner, laid and hatched her eggs on the bare ground without any nest, but simply in a little hollow scratched out at the foot, and under the shelter of a small bush."

It is sometimes no easy matter to remove an old nest of the thrush when placed upon the boughs of the laurel, the mud of which it is formed, kept moist by a wet season, will cause the branch to throw out roots which firmly bind it to the tree. The progress made by a thrush in the construction of its nest varies as much as the weather does at the season. In cold weather the work goes on very dilatorily, and sometimes ceases altogether. In fine weather a nest will be completed from the first bit of moss, plastered, and contain its first egg within a week. This year I was witness to the most marvellous piece of architecture I ever saw; a thrush had completed its nest in a fir-tree against the house, and had early one morning laid its first egg. At ten o'clock the nest was torn out and taken away, how I could not discover, but not, I 
believe, by human means; the rough grass which formed the bottom was all that was left. At ten the next day, much to my astonishment, I found that the birds had completely restored the nest-had again lined it with plaster, and that the female was then laying an egg: this time, as their perseverance deserved, they successfully reared their young ones.

The thrush lays four or five eggs spotted usually with deep black, rarely with red or purple-brown; sometimes they are without spots; those which are laid early in the year, and cluring cold weather, are often less and of a lighter blue than those which are produced afterwards. 
INCESSORES.

DENTIROSTRES.

\section{FIELDFARE.}

\section{TURdUS PILARIS.}

PLATE XXIV. FIG. III.

LIVING in a town which had fostered the existing taste for ornithology, and spread it widely throngh our native land by the immortal birds of Bewick, we had for long felt dissatisfied at the slow progress which was making in a knowledge of their nidification and their eggs.

In the hope of satisfying some of our own cravings, and more still of giving an impulse to one of our favourite pursuits, two bird-nesting expeditions to the north of Europe, planned during the winter of 1832, were successfully accomplished during the succeeding summer, one by Mr. G. C. Atkinson to the Feroe Isles and Iceland, of which I shall have to speak when we reach the waterbirds, the other to the coast of Norway, by my friends John Hancock, B. Johnson, and myself. Intending that the Fieldfare should be our avant courier to its native land, it was with peculiar interest that we watched its long lingering in our own for weeks after our blackbirds and thrushes had commenced their nidification. It was not until the end of April that the last of them took their departure from our neighbourhood.

In a few days afterwards, on the 14th of May, our first day in Norway, we enjoyed the pleasure of again seeing them in their own wild native woods, engaged so early after their arrival, in all the bustle of preparation for the 
production of other colonies, to visit us in future years. We had been out all day, rambling through those almost impassable forests, and after having climbed many a tree to no purpose,-to nests of the previous summer, which we supposed must have once been tenanted by the birds of which we were in search,-were returning home weary and disappointed, when suddenly the monotonous silence of the woods was broken by the loud harsh cries of a colony of Fieldfares, which, alarmed at our approach, were anxiously watching over their newly-established dwellings. We very soon forgot our toils in the delight which we experienced at the discovery of several of their nests, and were surprised to find them, so contrary to the habits of the rest of the genus with which we are acquainted, breeding in society. Their nests were at various heights above the ground, from four to thirty or forty feet or upwards, and mixed with old ones of the preceding summer; they were for the most part placed against the trunk of the spruce fir-tree; some were, however, at a considerable distance from it, towards the smaller end of the thicker branches. They resemble most nearly those of the ring ouzel; the outside is composed of sticks and coarse grass, and weeds gathered wet, matted together with a small quantity of clay, and lined with a thick bed of fine dry grass; none of them yet contained more than three eggs, although we afterwards found that five were more commonly the number than four, and that even six were very frequent; they are very similar to those of the blackbird, and eren more so to those of the ring ouzel and the redwing, but do not vary so much; indeed so closely do the eggs of the four species resemble each other, that a drawing of one might apply to all. They are all sometimes so closely freckled throughout that the colour of the freckles predominates; they all 
have a variety in which the ground colour is most seen, the red brown spots being larger and much more sparingly sprinkled. Mr. Wolley, writing from Sweden, says, that this summer he has found unfinished nests and freshlaid eggs of the Fieldfare near Kilix, on the 30th of May, that the four or five breeding-places which he found were amongst very young fir-trees upon the borders of the forest, and near cultivated land. The Fieldfare is the most abundant bird in Norway, and is generally diffused over that part of the country which we visited, from Drontheim to the Arctic Circle. It builds, as before stated, in society. Two hundred nests or upwards may be found within a small circuit of the forest. 

XXIV
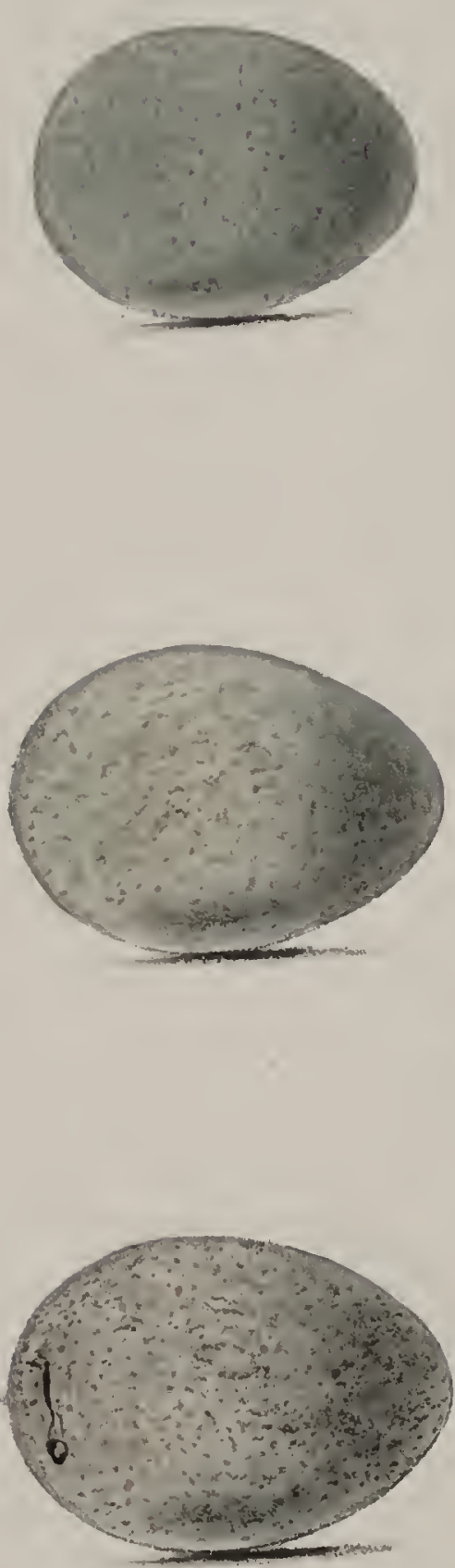
INCESSORES.

MERULIDAE.

DENTIROSTRES:

\section{REDWING.}

\section{Turdus iliacus.}

PLATE XXIV. FIGS. I. AND II.

In our long rambles through the boundless forest scenery of Norway, or during our visits to some of its thousand isles, whether by night or by day, the loud, wild, and most delicious song of the Redwing seldom failed to cheer us.

Unlike its neighbour the fieldfare, it was solitary and shy, and on our approach to the tree on the top of which it was perched, would drop down and hide itself in the thick of the brushwood.

Throughout that part of the country which we visited it is known by the name of nightingale, and well it deserves to be so; to a sweeter songster I have nerer listened. Like the nightingale of more southern skies, its clear sweet song would occasionally delight us during the hours of night, if the two or three delightful hours of twilight which succeed the long day of a Norwegian summer can be called night. The birds, like the other inhabitants of the country, seem loth to lose in sleep a portion of this delicious short-lived season.

Anxious to extend our researches onwards, in the hope that as we proceeded north we should prove more successful, we had lingered but little to search for the nest and eggs of the Redwing, and our inquiries with regard to them had been unavailing. One afternoon, as we 
approached the sea-coast, and at the same time the northern limit of a beaten road, we discovered a nest, but to our great disappointment it had young ones. Having almost reached the boundary of our woodland rambles for the present, we spent the whole of the following day in exploring the beautiful woods by which we were on all sides surrounded. We found a second nest, but the eggs were again hatched. It was here, too, that we saw the brambling, accompanied by its full grown young ones.

The nest of the Redwing, as far as I can speak from my own experience in Norway, is placed singly, like those of the thrush and blackbird, in the centre of a thorn or other thick bush. It is similar to those of the blackbird, fieldfare, and ring ouzel. Outwardly, it is formed of moss, roots, and dry grass; inwardly, it is cemented with clay, and again lined with finer grass.

The doubt which for a long time existed with regard to the eggs of the Redwing has been entirely removed of late. Collectors have received them in abundance from Iceland through Mr. Proctor, of the Durham University Museum, and from Norway tlirough Mr. Dann. M. Nilsson, to whom as a Swedish naturalist much deference was due, has described the eggs as blue spotted with black. $\mathrm{Mr}$. Yarrell had adopted this description in the first edition of his most useful work, and inadvertently repeated it in the second, and I must say, that my own prepossessions were greatly in favour of a blue egg, like that of our common thrush, and that I felt something like disappointment when it was ascertained to be otherwise.

Mr. Proctor, who has taken the eggs of the Redwing for several summers in Iceland, has kindly sent me the following very interesting information. "In Iceland, where there is scarcely any wood except the birch-tree, and 
that stunted to a dwarf, weather-beaten shrub, the Redwing builds amongst its branches, frequently supporting the nest upon those which overhang rocky ground. Sometimes the nest is placed at the base of the tree's trunk, and often upon a bare ledge of rock like that of the ring ouzel, which frequents similar desert wilds.

The Redwing is the only thrush in Iceland. It breeds in single pairs; and Mr. Proctor thinks that it has two broods in a season, that the first eggs are laid at the beginning of June on the south of the island, but that they are later by ten days on the north side. The eggs are usually four or five in number, and sometimes, though rarely, six. Those that I have figured are from the collection of Mr. Wilmot, both supplied by Mr. Proctor. They are usually somewhat smaller than those of the fieldfare, but at times, as will be seen by the second figure of the plate, do not differ from eggs of that species. They also closely resemble eggs of the blackbird and ring ouzel. Indeed we have no genus of birds in which the eggs of several species are so much alike.

Mr. Wolley, who has taken up his quarters at Muonioniska in Tornea Lapmark for the winter, says that the Redwing "makes its nest near the ground, in an open part of the wood, generally in the outskirts, on a stump, a $\log$, or the roots of a fallen tree, sometimes amongst a cluster of young stems of the birch, usually quite exposed, so as almost to seem as if placed so purposely, the walls often supported only by their foundation. The first or coarse part of the nest is made for the most part of dried bents, sometimes with fine twigs and moss; this is lined with a thin layer of dirt, and then is added a thick bed of fine grass of the previous year, compactly woven together, which completes the structure. Outside is often a good deal of the kind of lichen called rein-deer 
moss, and one nest particularly, which I have preserved, is entirely covered with it: when it was fresh, and the fine ramifications of the lichen unbroken, it had a most beautiful appearance. The nest of the Redwing can generally be distinguished from that of the fieldfare by the much less quantity of plaster used in its construction, none of which is visible till the nest is pulled to pieces; it is therefore relatively lighter, besides being of smaller size.

"The birds appear to be somerwhat irregular in their time of breeding. Of those nests which I saw near Muonioniska on the 13th of June, one had three young and two eggs ; another had five small eggs not long laid, and which, perhaps, belonged to a last year's bird; the third nest had four eggs, nearly ready to hatch. On the 8th of July, at this same place, I saw two nests with new laid eggs, but they might be second broods, or belong to birds which had lost their first; there were five egrgs in each of these two nests, and five appears to be the most common number." If further evidence was necessary, after the abundant information which kind friends have enabled me to give, Mr. Wolley adds, that on the 23rd of May, near Umea, he shot a Redwing, and took from it a mature egg, resembling those from Iceland and Sweden. 


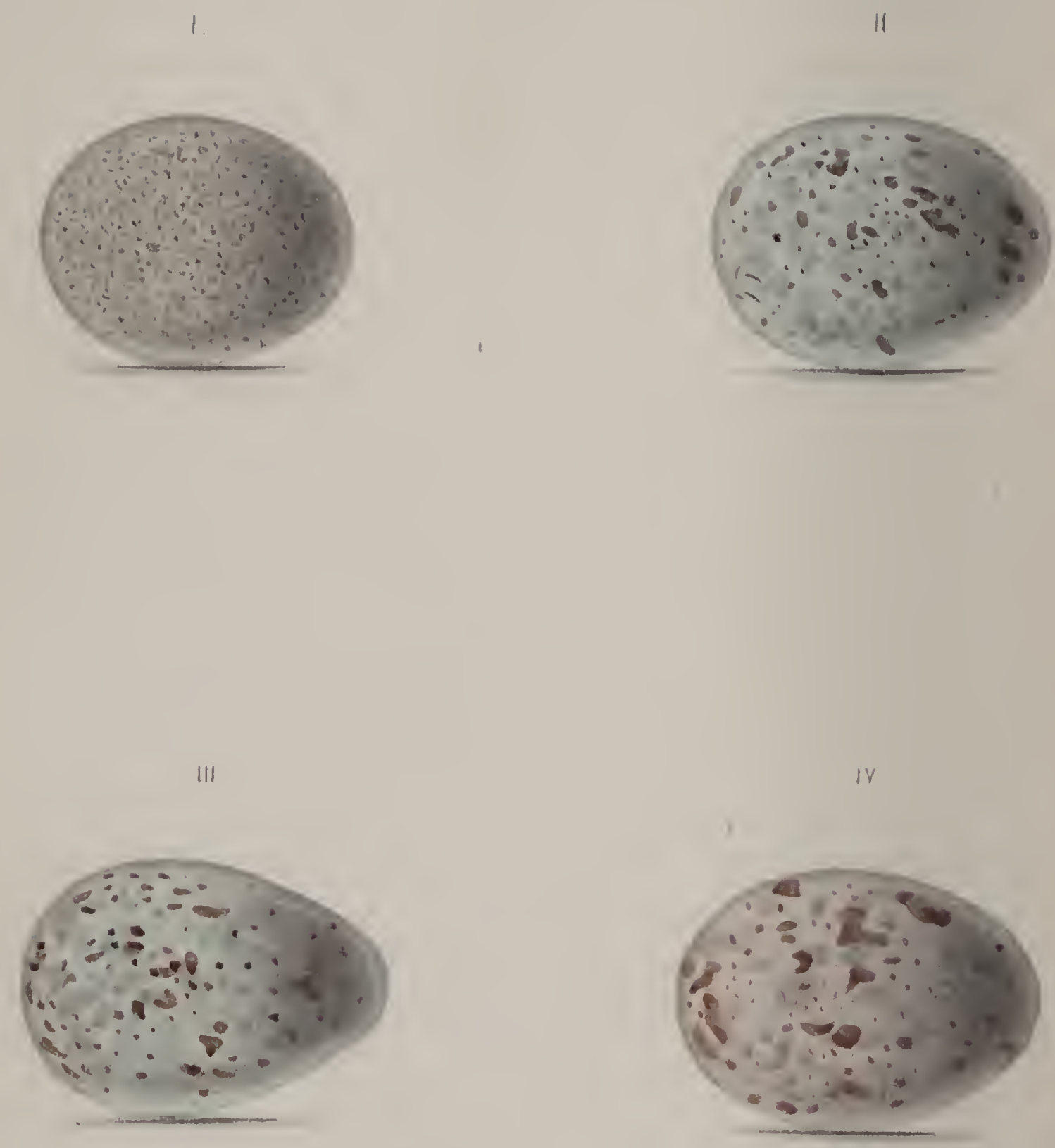


\section{BLACKBIRD.}

\section{Turdus merula.}

PLATE XXV. FIGS. I. AND Ir.

In its time of incubation, and in the position of its nest, the Blackbird differs very slightly from the thrush.

The nest, which is sometimes very much exposed, may be met with in thorn hedges, or single bushes, in evergreens, occasioually on the top of a naked stake-fence, on the summit of a wall, or in a heap of dead sticks. I have seen it within a few inches of the ground, on the stump of a felled tree.

It is formed chiefly of grass, with a few dry sticks, roots, and dead leares, cemented together with mud, which it uses in a much greater quantity than the thrush, and is then lined with fine dry grass.

The eggs, which are four or five in number, vary much.

Figure 1. represents a common variety, although not the most typical I could have chosen. I have figured it to make the drawings - at the same time that they represent each species-illustrative of the whole genus; figure 2, a variety, much resembling eggs of the ring ouzel; a variety similar to the last, except that the ground colour is lighter, and the spots smaller, is not unfrequent. I have a beautiful egg of this species, of a clear spotless light blue, with the whole of the larger end suffused with reddish-brown. 'The Rev. A. C. Smith has kindly sent me a 
very beautiful egg, such as I have never seen before; it is of a clear green-blue, with numerous minute spots and some large blotches of delicate light red brown and purple, with two or three spots of black at the larger end. My friend, Mr. Henry Doubleday, found several nests of the Blackbird in Epping Forest, the eggs of which were of the fine blue of the thrush, and without spot.

The eggs of the Blackbird are frequently of an oval form, the smaller end being rounded and obtuse, a character which I have not noticed in the allied species. 


\section{RING OUZEL.}

\section{Turdus torquatus.}

PLATE XXV. FIGS. III, AND IV.

The Ring Ouzel is rather a local bird, and is much more abundant in the north than in the south of England. It is seldom seen except in the wild mountain districts, which are its favourite haunts. It breeds in several parts of Northumberland, and the wilder portions of Derbyshire; and is abundant on some of the Yorkshire moors, especially about Halifax.

It builds its nest upon the ledges of the picturesque gray rocks, which are the peculiar feature of these mountain districts. It is rery similar to that of the blackbird, and is outwardly composed of pieces of heather and coarse grass, with a slight layer of clay, and thickly lined with dry fine grass. It is frequently roofed over by a projecting ledge of rock, or a bunch of heather.

The eggs are four or five in number; they are more like those of the fieldfare than those of the blackbird, and very rarely resemble the common closely freckled egg of the latter. They are frequently more closely marked than figure III. of the plate, and with much lighter spots of red-brown and purple, and in some of their varieties resemble the figure of the egg of the fieldfare.

Figure IV. is a variety of unusual beauty and a good deal like the eggs of the missel-thrush. 


\section{GOLDEN ORIOLE.}

\section{Oriolus galbula.}

PLATE XXVI. FIG. I.

The Golden Onole, though quite a rare visitor in this country, is rather common in Italy and the south of France. In Germany, at least that part of it which I have visited, it is rare. Once only whilst wandering: through the forests of Bararia, its bright tropical colours caught my eye.

Mr. Meyer has figured a nest of this bird, said to have been taken in Suffolk. Mr. Yarrell has also had a drawing made for his 13irds from one in the collection of the Zoological Society.

The Golden Oriole generally builds in high trees, but places its nest in a low part of the tree, upon the forked extremity of a horizontal branch. It is composed of dry grass, roots, and wool, lined with similar materials of a finer texture.

Mr. Alfred Newton says that in looking over a large series of the eggs of this species, he has observed that very long-shaped examples are unusually prevalent, that one in his collection is an inch and three-eighths in length, with the usual breadth. 
XXVI.

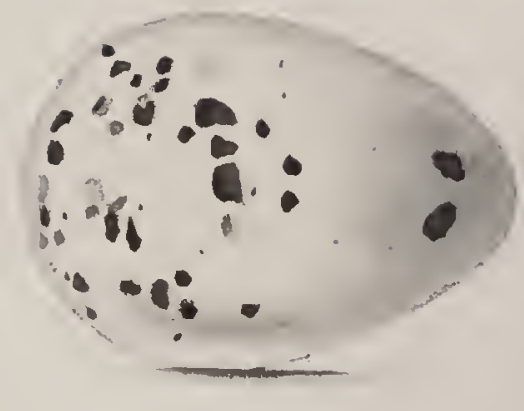





\section{ROCK THRUSH.}

\section{Petrocincla saxatilis.}

PLATE XXVI. FIG, $\mathrm{I}$.

THIs beautiful bird, which Mr. Gould says very truly manifests a relationship to the Saxicolæe, frequents similar rocky districts, and is met with in the Swiss Alps, in the Pyrenees and Tyrolese Alps, and Mr. Yarrell, who states that this bird has been twice killed in England, says that it inhabits Germany, France, and various parts of Spain, particularly the rocky districts about Aragon. I am indebted to the Rev. S. C. Malan for the following notes. "I had, years ago, frequent opportunities of watching the habits of the Rock Thrush while residing in the neighbourhood of Genera. It is not by any means a rare bird at the foot of the Seleve, a few miles from that city. It nestles not in rocks, but among broken fragments of rocks and loose stones. The nest is loosely built, lined with hair; the eggs five in number. They vary in intensity of colour, and are not unfrequently speckled over with a few scattered dark-brown or purplish-brown spots." The egg which I have figured has been kindly supplied to me from the collection of one of my oldest oological friends and correspondents, Mr. J. D. Salmon. 
INCESSORES.

DENTIROSTRES.

\section{ALPINE ACCENTOR.}

\section{ACCentor alpinus.}

PLATE XXVII. HIG. II.

This species, as its name implies, is an inhabitant of Alpine countries. It is met with in the mountainous regions of Europe, and especially of those districts which are of a rugged and rocky character. Mr. Selby says that "it is very common upon the Swiss Alps, and may be always seen by travellers in the environs of the convent upon Mount St. Bernard. In summer it ascends to very elevated stations, where it breeds in holes and under ledges of the rocks." I have seen many of them, during the breeding-season, on the Pass of the Gemmi, and on the ascent of the Great St. Grothard from Fluellen, before reaching the Devil's Bridge. Its nest is composed, like that of the hedge-sparrow, of moss, dry grass, and wool, lined with hair. The eggs are four or five in number, and like those of the allied species, of a beautiful spotless blue, but rather more intsnse in their colouring. 
XXVII.
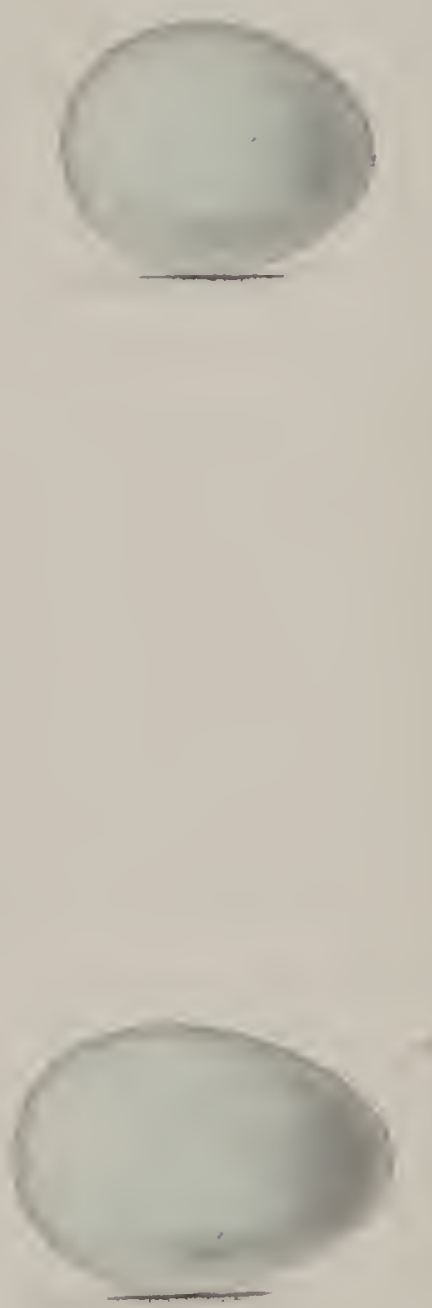


\section{HEDGE ACCENTOR, HEDGE SPARROW.}

\section{ACCENTOR MODULARIS.}

PLATE XXVII. FIG. 1.

This gentle, unobtrusive little bird, though neither brilliant in plumage nor yet in song, has many claims upon our regards. 'There is no other species of bird, with the exception of the house sparrow, which is so much in our immediate neighbourhood the year round; and in the winter, when all the rest have become mute, except the robin and the wren, it ceases not to utter its monotonous, though agreeable notes.

Every one must remember the bright blue egg which first caught his boyish fancy, and the pleasure he has derived from its discovery and possession.

The Hedge Sparrow is one of our earliest breeders, and begins to lay its eggs in March or the beginning of April.

The nest is usually placed in a garden or orchard fence, or that of the field adjoining, or in some bush in the garden; sometimes in a furze-bush, or in iry against a wall. I do not remember to have ever found one except near to some habitation.

The nest is composed of pieces of stick, coarse grass, moss, and bits of wool, and is lined with hair. Sometimes it is built almost entirely of dry grass.

In two instances I have seen the nest of this bird so imperfectly finished that the thorns were sticking through the inside, apparently very much to the discomfort of the old bird. The eggs are four or five in number. 


\section{ROBIN REDBREAST.}

Erythaca rubecula.

PLATE XXVIII.

In the springtide and summer of the year, when his sweet and cheerful notes are superseded by the loud carols of a thousand minstrels from abroad, the Robin is busy making his nest and rearing his young ones, away in the shady woods and green lanes of the country; when, however, the sunny summertide is gone, and the silent groves have been decked in all the gorgeous colouring of autumn, when the leaves, so lately green, are strewed around us by the drifting winds of November, then it is that our constant and familiar friend comes near our dwelling, cheering us at the earliest dawn of morning with his plaintive music, and again at eve till the last departing gleams of day have given place to the gloomy shadows of the night.

If the weather remains mild and open, and worms are to be had, we see little of him except when he comes to chant his morning and evening greeting under our window.

Should the severity of the frost, or the pitiless snowstorm deprive him of his daily food, we begin to feel an interest in his fate, and the beautiful language of Burns occurs to our recollection:- 
XXVIII
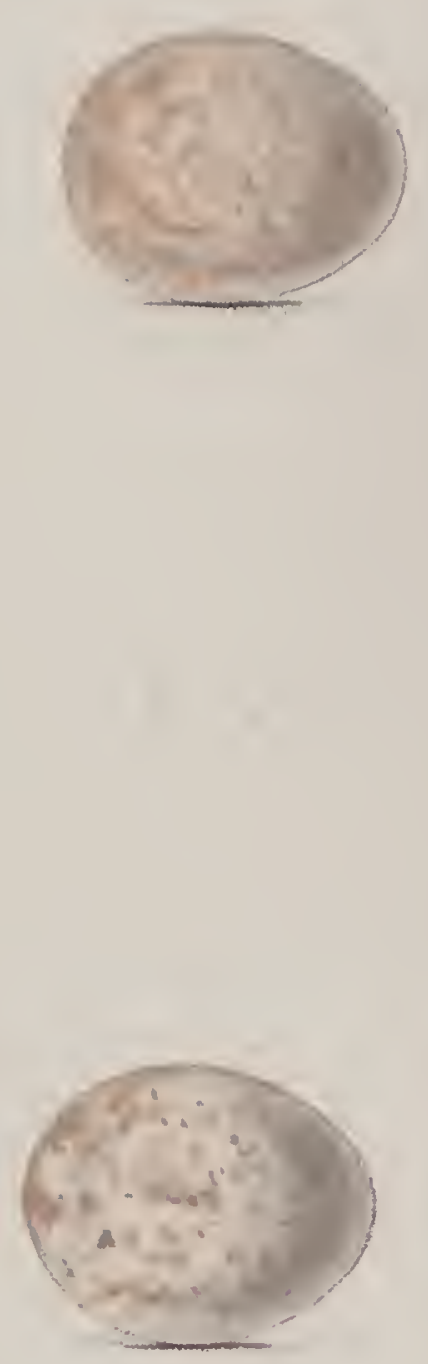

"Ilk happing hird, wee, helpless thing,

That in the merry months o' spring,

Delighted me to hear thee sing,

What comes o' thee?

Whare wilt thou cow'r thy chittering wing

An' close thy e'e?"

Then it is, that this dear pet of our childhood, presuming upon the kindness with which his race has ever been treated, will alight upon our threshold, and becoming more familiar each day, may be persuaded to pick the crumbs from our table, and even to become a cherished inmate of our dwellings.

"Half afraid, he furst

Against the window beats; then brisk alights

On the warm hearth; then hopping o'er the floor,

Eyes all the smiling family askance,

And pecks, and starts, and wonders where he is ;

Till more familiar grown, the table crumbs

Attract his slender fect."

Amongst the oft-recurring memories of the past, there are few that come to my recollection with more undiminished enjoyment than the events of a severe winter.

Myself, and a brother who is now no more, were then learning our ornithological alphabet, and imbibing our first taste for natural history from the works of Bewick, one of the truest naturalists that our country has ever seen. Outside our window was a wide ledge, which being liept thickly strewed with bread crumbs, attracted a constant succession of visitors, which we had no difficulty in identifying with the beautiful fac-similes before us; and such was the pinching influence of the cold, that at one time we had even rooks among the rest; but of them all none was so welcome as the Robin, and great indeed was our delight when we succeeded in inducing one to take up his quarters with us for the night. 
He would return every evening as regularly as the decline of day, and not only stayed with us the whole of that winter, roosting on one of the bell wires, but continued to do so for some succeeding years, till, upon our being sent to school, our playfellow was forgotten.

It is, however, singular that several years after this a Redbreast-it may have been the same one-used to spend its winter nights in my father's bed-room, when he was much interested by watching it and another, its companion, which would come at times to the window, to join it when liberated in the morning.

When engaged in railway surveys during the winter I have known the Robin come without fear or harm, to beg a crumb from the dinners of our workmen, and eat it off their hands.

The nest of the Robin is composed of moss, dried grass, and dead leaves, lined with hair, and sometimes a few feathers; its natural position is a hollow in the side of a woody bank, or of a country lane, where it is sheltered by the overhanging brushwood; it is not unfrequently found in the hole of an old ruin or garden wall; and may be met with in as many whimsical positions as the nest of the spotted flycatcher.

Mr. Selby mentions having known several instances in which it occupied the inside of a watering-pot, and $\mathrm{Mr}$. Blackwell describes one which was built in the side of a sawpit, where people were at work.

Although I have stated that the Robins betake themselves to the country to spend the joyous months of summer, many of them remain near us. Mr. J. H. Tuke informs me that they had no less than four nests of this species in their garden in York, during the last summer. They had placed flower-pots for the purpose in different parts of the garden, and had the pleasure of seeing four 
of them occupied, each by the nest of a different pair of Robins.

A pair of Redbreasts had their nest in some ivy against a garden wall near Newcastle, which the owner was about to remove, but being unwilling to disturb its tenants, he took the nest and eggs, and placing them in a neighbouring bush, had the satisfaction of seeing the old bird again reseated on her eggs.

The eggs are mostly four or five, sometimes six, and even seven in number; they differ a good deal in colouring, some are almost, some perfectly, white, others are sparingly but distinctly spotted, and resemble eggs of the green linnet, whilst the majority are like the first figure of the Plate. 
INCESSORES.

SYLVIADAE.

DENTIROSTRES.

\section{BLUE-THROATED WARBLER.}

\section{Phenicura Suecica.}

PLATE XIIX, FIG. I.

VERY few specimens of this beautiful bird have yet been killed in this country; the first of which there is any record, was shot upon the town moor of Newcastle-uponTyne, and is now in the Museum belonging to that town.

The only account which we have of the habits and nidification of this species, is the following, which is given by Mr. Yarrell, from the pen of the late Mr. J. D. Hoy, his observations being made during a bird-nesting visit to the Continent.

"This bird makes its appearance early in spring, preceding that of the nightingale by ten or twelve days. I have always found this species during the breeding-season in low swampy grounds, on the woody borders of boggy heaths, and on the banks of streams running through wet springy meadows, where there is abundance of alder and willow underwood.

"The nest is placed on the ground amongst plants of the bog myrtle, in places overgrown with coarse grass, on the sides of sloping banlis, in the bottom of stubs of scrubby brushwood in wet situations. It is well concealed, and difficult to discorer. I do not believe they ever build in holes of trees. 
XXIX
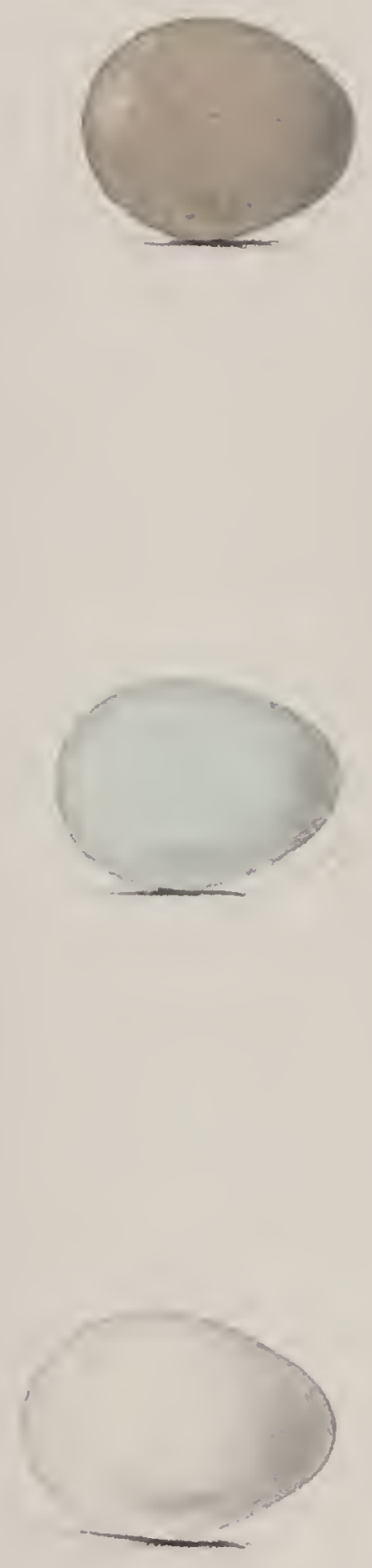

"The nest is composed, on the outside, of dead grass and a little moss, and lined with finer grass. The eggs are from four to six in number," and usually resemble the one figured; one, which Mr. Alfred Newton has sent me from his collection, is of a uniform olive-brown, as dark as the egg of the nightingale, from which it differs only in size.

Acerbi mentions his having found several nests and eggs of this bird on the banks of the river Jeres, at the head of the Gulf of Bothnia. It is also an inhabitant of some parts of Norray. In that portion of the country which we visited it is rare, and only once afforded us an opportunity of seeing it, and then under circumstances which I can never think of without feelings of extreme pleasure. We were descending the steep and woody sides of one of the numerous islands with which the Norwegian coast is so thickly studded. It was after midnight, and the sun, which we had just seen set in glory above the horizon, was now with its rising beams diffusing an additional warmth over the face of nature, and adding a lustre to every beautiful and magnificent object around us; Nature, which during the short delicious summer of these regions, seems scarcely to allow time for slumber or repose, was thus early in activity. The bees came humming past us, and a Blue-throated Warbler, which was in motion amongst the low brushwood, arrested our progress.

Although classed with the redstarts, in the little we saw of its habits, this species seemed much more to resemble the birds of the genus Curruca or Sylvia, in its hiding skulking manner. 
INCESSORES.

SYLVIADA.

DENTIROSTRES.

\section{REDSTART，REDTAIL，FIRETAIL.}

Phenicura ruticilla.

PLATE XXIX. FIG. II.

T'He Redstart is amongst the most familiar of our summer visitors, frequenting our towns and rillages, and building its nest in a hole in the garden wall, or the hollow of some tree.

There its oft-repeated and monotonous note may be heard throughout the day, uttered sometimes in a tone of so much apparent anxiety and distress, that one is led to expect some enemy prowling near, and such is too frequently the case: numerous are the broods of this and other species of our friends, which fall an easy prey to the numerous cats that are ever on the watch.

The nest of the Redstart is formed chiefly of moss and dry grass, lined with hair and feathers. Two nests sent me by my friend the Rev. W. D. Fox, differ so much that I will describe them separately. One, taken from a hole in a tree, was formed of moss, grass, and a few dry leaves, lined with a quantity of wool, mixed with fine grass and hair. The other, from a wall, was chiefly of dry grass, moss, and wool, with finer grasses and hair towards the inside, and lined with a profusion of white feathers.

The eggs, which are from five to eight in number, are smaller than those of the hedge sparrow, of a more slender and delicate form, and usually of a lighter blue. 


\section{BLACK REDSTART.}

\section{Phenicura tithys.}

PLATE XXIX, FIG. III.

IN its habits and the position and materials of its nest, this species very closely resembles the Common Redstart.

When at Kissingen in Bavaria, I used to watch several of these birds, which had their nests in buildings in the environs of the town. It was towards the end of June when they had all young ones. 'Two pair of these had their nests in the walls of a salt manufactory, a building of great length for the purpose of evaporating salt water.

The nests were composed of moss, dry grass, and wool, lined with bair and feathers.

Mr. W. R. Fisher, of Yarmouth, has kindly sent me the following memorandum relative to the Black Rerlstart:"I took the nest of this bird in Germany. It contained six eggs, which at first, from the transparency of the shell, were of a pink colour, but when blown, quite white. The nest was placed in the angle formed by two cross beams in the roof of an inhabited house, and was chiefly composed of worsted yarn, a quantity of which I found lying near the spot; I observed that the bird remained all the winter, and have since been told that it returns annually to the same place to breed." The Black Redstart lays five or six eggs, which, when blown, are of a purer white than those of any other bird which I have seen. 
On reading a notice in the Zoologist as to a supposed nest and eggs of this species, I should have been led to pass it by as insufficient, having from a boy at school been yearly puzzled by white eggs of many species. Mr. Hawkins has, however, kindly sent me one of the eggs to look at, which, from its size, shape, and the very delicate white and texture of its shell, can scarcely be a white variety of the egg of any other British bird. Mr. Hawkins observes, that this occurrence is only a link in the chain of evidence, and that he has since been assured by a respectable person in his neighbourhood that he knew of a nest of these birds (the male of which he describes accurately), that he had often watched the birds whilst building their nest, which was in a wall, and contained white eggs larger than those of the Common Redstart, which he knows well. 
$X X X$
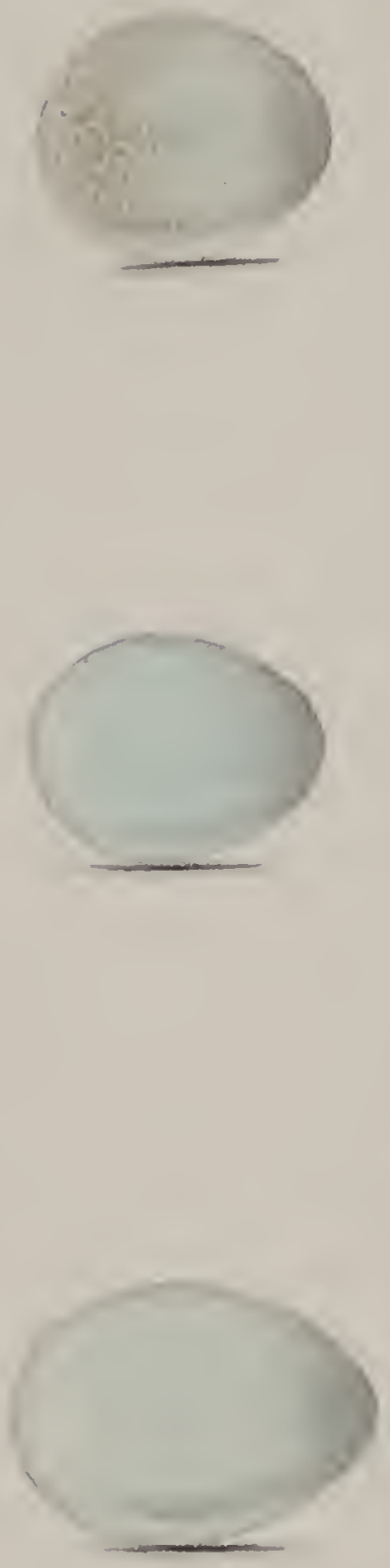


\section{STONECHAT.}

\section{Saxicola rubicola.}

PLATE XXX. FIG.I.

The Stonechat is much less common than either of the succeeding species; it breeds, too, in places less frequented, on furze-covered commons and on heaths. The nest is placed on the ground, at the bottom of a furze or stunted thorn-bush, or amongst the heather; it is composed principally of grass, with a small quantity of moss, hair, and a few feathers loosely put together; the eggs are five, or more commonly six in number, sometimes, though rarely, seven; they are readily distinguished from the spotted variety of the eggs of the whinchat, being much less blue, and more closely freckled throughout with light reddish-brown. The Stonechat breeds in May or June; it is, however, very difficult to mention any particular date for the time of nidification of our smaller birds, as individuals of the same species are frequently building their nests, laying their eggs, sitting them, or feeding their young ones at the same time. In confirmation of this, Mr. A. Newton tells me that he has known nests of the Stonechat early in April, and has seen young ones scarcely able to fly at the end of August. 
INCESSORES.

SYLVIADAE.

DENTIROSTRES.

\section{WHINCHAT, GRASSCHAT.}

\section{Saxicola RUBETRA.}

PLATE XXX. FIG. II.

The Whinchat is not, as its name might imply, so entirely an inhabitant of those furze-corered hedgeless districts, as the other two species of Saxicola. In one of the rich grassy vales of Westmoreland, where I was at school, it was abundant, and there the name of Grasschat, by which we used to know it, was suited to the nature of the country round.

They were so plentiful, that any evening on which we bent our bird-nesting rambles to the inclosures, we were usually successful in finding two or three of their nests. These were either placed in a tuft of grass in a rough pasture field, or amongst the thick grass of the meadows, which, at this time of the year, May or June, was long. and fit for cutting; and I have often since wondered at the good-nature of the farmers, who suffered us thus to roam unmolested among their crops.

The furzy common is, however, perhaps the most favourite resort of this species, where it places its nest, like that of the stonechat, at the foot of a furze or stunted thorn-bush, or amongst some heath; sometimes, though rarely, it is placed in the centre of a piece of thick furze, a few inches above the ground.

'The nest is composed outwardly of the stalks of plants 
and dry grass, with a small portion of moss, and is lined with finer grass; like the nests of most birds that build upon the ground, it is very slightly woven together, and is not easily brought away whole.

The eggs, which nearly all of our ornithologists have described as of a spotless blue, are quite as frequently very finely dotted, and sometimes, though very rarely, distinctly spotted with rust colour; they are almost invariably six in number. 
INCESSORES.

SYLVIADAE.

DENTIROSTRES.

\section{WHEATEAR, WHITERUMP.}

\section{Saxicola cenanthe.}

PLATE XXX. FIG. III.

The Wheatear frequents open downs and commons, making its nest in the stone walls or turf dykes, by which they are intersected. Mr. Knapp informs me that they frequently make their entrance by a hole at a considerable distance from the nest, passing to it through the interstices between the stones; and that he had in consequence greater difficulty in procuring the eggs of the Wheatear than those of almost any other bird in his own neighbourhood; and was not.successful till he had offered a premium for them amongst the boys of his parish.

Mr. Yarrell, quoting the information of Mr. Salmon, states that the Wheatear is rery abundant in the warrens of Norfolk and Suffolk, and usually selects a deserted rabbit-burrow, in which it places its nest at some little distance from the entrance.

It will also make its nest in the side of a stone quarry or gravel-pit, or upon the ground under the shelter of a stone or clod of earth. I have found it also in the sandbank of a river, at the mouth of a hole perforated by the sand-martin. It is made of the finest dry grasses, mixed 
throughout with small pieces of wool or moss, feathers and hair, the outside being nearly as fine as the lining. The eggs are five or six in number, and very elegantly formed. Sometimes, though very rarely, they are slightly dotted with brown: thus, again showing the usually close generic resemblance of eggs, and how apparent discrepancies vanish as our knowledge increases. 
INCESSORES.

GRASSHOPPER WARBLER.

Salicaria locustella.

PLATE XXXI. FIG. I.

THE very shy and skulking nature of this species has always made it difficult to become familiarly acquainted with its habits, and still more so to obtain its nest and eggs; the first that I ever saw was in the collection of Mr. Wingate, of Newcastle, who is well known in the north of England for his life-like manner of mounting birds. I quote his account of its discovery from the pages of Bewick's Birds. He says, that "having long wished to get the egg of this bird to add to his curious collection, he at length, in June 1815, after much watching, succeeded in eyeing it to the distant passage on the top of a whin-bush, by which it entered and left its nest. Its curious habitation he found was built at the bottom of a deep narrow furrow, or ditch, overhung by the prickly branches of the whin, and grown over with thick coarse grass, matted together, year after year, to the height of about two feet. Before he could find the object of his pursuit he searched until he was wearied, and at length found that there was no other plan left but that of taking arvay the grass by piecemeal, which he was obliged to do before he could obtain the prize."

The nest of the Grasshopper Warbler is composed of a large quantity of grass, so loosely put together that those which I have seen could have occupied no other situation 
$X X X I$
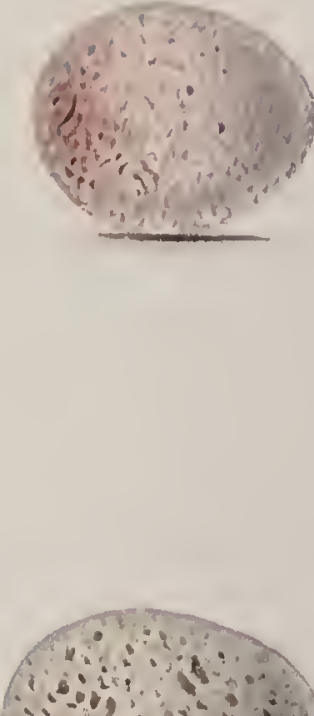

-

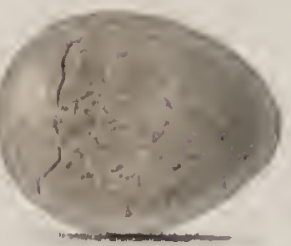



than the ground. The eggs are five or six in number, Mr. Yarrell says, sometimes seven; they rarely vary so much as to render their identity at all doubtful.

In the collection of Mr. Knapp are two specimens, which are more remote from the usual appearance than any I have seen; the minute dots, which are usually thickly sprinkled over the whole surface of the egg, are in these examples concentrated, so as to form a distinct ring round the larger end. Another variety, in the collection of the Messis. Tuke, has the ground-colour of a pure white.

I once had a nest of this species brought to me, which contained seven eggs, one of which belonged to the cuckoo.

The Rer. W. Turner of Uppingham, one of my correspondents during the progress of the British Oology, has the following interesting remarks in the Zoologist. "Having in 18.35 and twice since found the nest of the Grasshopper Warbler, I am enabled to give the following particulars of the nidification and habits of that skulking bird. The first nest was about the middle of a small plantation, of four or fire years' growth. Out of a tuft of grass, overarched by a bramble, and containing a small plant of white thorn, I observed something hop, as it were, and immediately drop into the herbage. I examined the tuft in hopes of finding a nest of something or other; but a careful search resulted in nothing but disappointment. In the course of the day I returned to the spot; there was the same hop and away, but the motion was so short and quick that I could not even then distinguish whether $I$ had seen a bird or a mouse. I repeated my search for a nest, but with no better success than before. I then sat down by the spot to watch if anything would approach, and it was not long before I observed the grass move and a veritable Sylvia lo- 
custella (threading its way through the grass), approached within arm's length of me; but, after eyeing me for a moment, it commenced a retreat. Feeling confident there must be a nest, I took my knife and carefully cut away the herbage near the tuft, and then proceeded with the tuft itself, in the very centre of which, and in a depression of the ground, I found the object of my search, but to the very last there was not the slightest appearance of ingress or egress. I was so struck with what I had witnessed that I again sat down, and ever and anon the same stealthy movements to and fro were repeated. The other two nests I detected in the same manner, in small open places in an extensive wood: their situations were exactly alike, being in the centres of two very large tufts of coarse grass, at a depth of fourteen or fifteen inches from the top. In both cases I watched the movements of the female, and they were precisely the same as I have already described: she never rose on the wing; and it would seem probable (if not disturbed) she never flies either to or from her nest, but threads her way through the herbage, and thus effectually prevents everything that could lead to the discovery of her retreat.

"The whole proceeding most forcibly reminded me of a mouse under similar circumstances. The nests in the two latter instances were entirely of dry grass, finer internally; in the first there was a little moss, owing probably to a trifling difference of situation." 


\section{SAVI'S WARBLER.}

Salicaria luscinoides.

PLATE XXXI. FIG. II.

This is one of the several birds that the spreading taste for Ornithology-which received its first impulse from the beautiful works of Berrick-and the discrimination of its votaries, have of late years added to the fauna of this country. Like the other species which it closely resembles in habits and appearance, it frequents districts which are covered with marsh and difficult of access, creeping about and hiaing itself mouse-like amongst the low brushwood.

Several specimens of this species have been discovered in the fens of Cambridgeshire, some of which are in the British Museum.

Mr. Bond, to whose kindness I am indebted for the pleasure of figuring this rare egg, received it-together with the nest, which contained three eggs, and from which the bird was shot - from the fens a few miles from Cambridge. The nest, which is beautifully symmetrical and round, and built entirely of the broad grassy top of the reed, was placed in a thick bunch of sedge upon the ground.

The eggs are considerably larger than those of the grasshopper warbler,- and one of them is a good deal larger than that which I have figured,-and bear some resemblance to them, but are much more like those of 
the woodlark and the pied wagtail, the eggs of the latter being sold by dealers to represent the eggs of Savi's Warbler. Mr. John Hancock tells me that a second nest and eggs of this species, together with the birds, which were also obtained in the fens of Cambridge, and which agree exactly with those sent me by $\mathrm{Mr}$. Bond, are in the collection of Mr. Robson, of Swalwell, near Newcastle.

Mr. W. H. Simpson, in a letter to a friend, says :"The last time I saw Savi's Warbler was in Burwell fen (now drained), in the month of May, 1849. At that time I saw several, and searched most carefully for their nests, but it was too early. In the same month of the same year a Savi's Warbler's nest was taken in the fen, not far from Whittlesea Mere, by a man I employed at that time. It was placed low down amongst the sedge, and there were two eggs in it. This fen is now, or shortly will be, a corn-field."

Mr. Green, a dealer in birds' eggs, mentions having taken a nest of Savi's Warbler at Dagenham, on the 14,th of May; the nest was built solely of reeds, and exactly resembled that figured in the "Zoologist." It contained five eggs.

Savi's Warbler is apparently a rare bird throughout the Continent, and was probably at one time-before the draining of our fens-as abundant here as in any other part of Europe. 
SEDGE WARBLER.

\section{Salicaria Phragmitis.}

PLATE XXXI. FIG. III.

The nest of the Sedge Warbler, though it bears considerable resemblance to that of the following species, is evidently intended for a situation less under the influence of every passing breeze; it is neither so deep -though much more so than the nests of most other birds,-nor yet so beautifully light. The nests of this species vary much in the neatness of their construction; some are compact and strong, and, like those of the genus Sylvia, formed of umbelliferous plants, with a few grasses, and a little moss; others contain a much larger proportion of the softer materials, and are fragile, and easily fall to pieces. All that I have seen were lined with the fine tops of umbelliferous plants, and flowering grasses divested of their seed, with, at times, a small portion of wool, hair, or the soft downy substance of thistles, and other plants. They may occasionally be found, like those of the reed-warbler, amongst reeds, - the Arundo phragmites,-from which the bird derives its name, but in a less elevated position; sometimes amongst rushes; and at other times in a low bush, or amongst the many kinds of tangled brushwood which constitute a hedge bottom. The eggs are four or five, and usually closely freckled all over, 
and so nearly resemble eggs of the yellow wagtail, that it would be difficult to know them apart, or even to separate them if together; they are sometimes of a uniform dirty yellow, and $\mathrm{Mr}$. Heysham mentions a nest in which three of the eggs were perfectly white. 


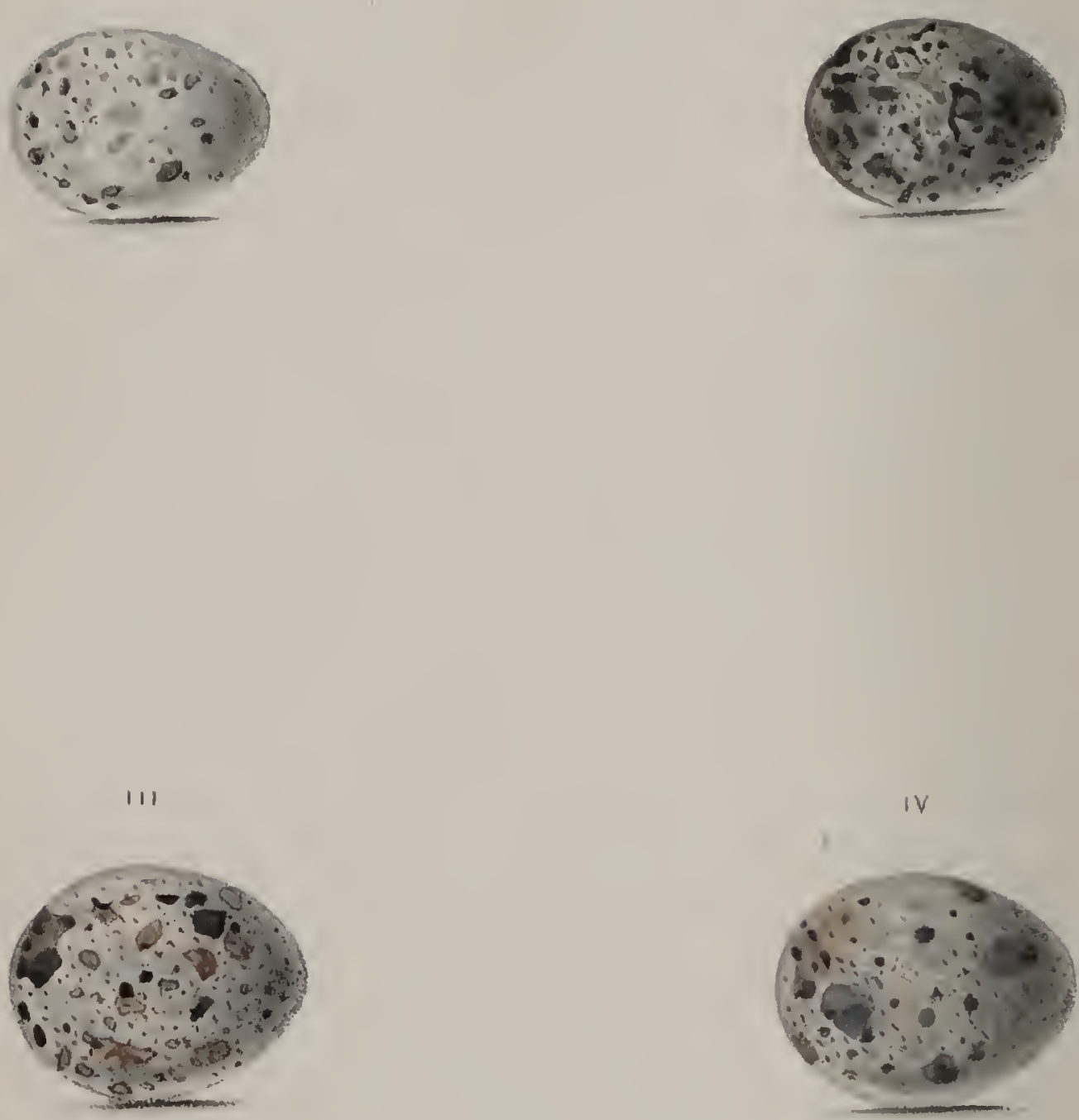
The nest of the Reed Warbler is one of the most beautiful of those of our British Birds, and reminds one, when looking at it, of some of those curious structures which the same natural instinct has taught the gaily-coloured inhabitants of other lands to form, as a protection from the dangers that surround them.

Were it not for its peculiarly-formed nest, the young ones of this species would be subjected to as much danger from every passing breeze, as the birds of tropical countries have to dread from their numerous enemies. To pursue the comparison still further, there is as much ingenuity shown in entwining the nest of this species, and binding it round the several reeds to which it is attached, as is displayed in the leaf-cradled nest of the tailor bird.

Built, as the nest of this bird is, high upon the reeds, which are agitated by every wind that -blows, the eggs would be in continual danger of rolling out, were it not for the admirable adaptation of the nest, which is so small in its diameter, and so much deeper, in proportion to its size, than the nests of other birds, that although, as observed by Montague, the reeds amongst 
which it is placed are often bowed by the wind to the surface of the water, the eggs and young ones ride secure.

To Mr. Henry Doubleday, of Epping, and Mr. J. J. Briggs, of Melbourne, Derbyshire, who finds them in his own neighbourhood, I am indebted for several of the nests of the Reed Warbler, together with the eggs. Each nest is supported by four or five reeds, and forms a singularly beautiful object, the long grassy leaves of the plant bending over it.

The nest is composed almost entirely of the flowering tops of reeds, finer towards its centre, which is sometimes completed by the addition of a few hairs; the outside is bound round and kept firm by lon'g grass, mixed with wool, which is at the same time twisted round the reeds. A good figure of the nest is given in "Yarrell's British Birds."

The eggs, which are four or five in number, although in some of their varieties resembling those of the sedge warbler, are yet readily distinguished by their deeper colouring, which is for the most part in distinct spots. I have seen a few of these eggs, which are rather like those of the whitethroat. The variety at fig. 2, from the collection of Mr. A. Newton, is a good deal like some of the eggs of Sylvia Orphea. An egg in the collection of Mr. Bond is nearly white, slightly marked with gray spots.

Bolton mentions having found a nest of this bird in a low hazel; and Sweet met with another in the low side branches of a poplar.

I must confess that I read these statements with something of incredulity, until the last summer, during which, Mr. Brown, a bird-stuffer in Bath, procured for me several nests from gardens in that city, lying near the 
river. These were placed indiscriminately, in any shrub most conveniently situated for the purpose; one was in a lilac, another in a lauristinus; and since in such a position the precaution was unnecessary, they were not of the usual depth which commonly characterizes the nests of this species. They were not deeper than the nests of the sedge warbler, and were composed almost entirely of grass, with bits of moss bound together with wool and spiders' webs, finer towards the inside; in one only there was a few hairs.

To avoid much error, I have adopted the name of this species which Mr. G. R. Gray has shown claims the priority, Arundinacea being by right the name of the great sedge warbler, leaving the specific name of turdoides to be borne by the thrush nightingale (Philomela turdoides), and thus avoiding the confusion which must arise from having two nearly allied birds bearing the same name. With one exception (that of two species of the same genus bearing it) a specific name, be it appropriate or not, even if incorrect in spelling, should never on any pretence be changed. A specific name accompanied by a figure or description is a copyright for ever of the giver, and no one who has a love for natural history would attempt to rob-a brother naturalist of his right, or to cumber science by naming for a second time an insect or a bird which he knows has been named before. 
INSESSORES.

$S Y L V I A D A$.

DENTIROSTRES.

\section{GREAT SEDGE WARBLER.}

\section{Salicaria Arundinacea.}

S. TURDOIDES.

PLATE XXXII. FIGS. III. AND IV.

Naturalists have to thank Mr. John Hancock, of Newcastle, that they can call this species British. I quote his own words, which record the fact, from the "Annals of Natural History." "A male specimen of this fine warbler was shot three or four miles west of Newcastle, near to the village of Swalwell, by $\mathrm{Mr}$. Thomas Robson of that place, on the 28th of May. The attention of this gentleman, who is perfectly familiar with the song of all our summer visitants, was arrested by a note which he had not before heard, and after some search he succeeded in getting a sight of the bird. It was concealed in the thickest part of a garden hedge, close to an extensive mill-dam, which is bordered with willows, reeds, and other aquatic plants. It would scarcely leave its retreat, and when it did so, never flew far, and always kept close to the herbage. Its habits resembled those of the reed fauvette, being continually in motion, occasionally hanging with the body downwards, or clinging to the branches, and stretching forwards to take its prey. From the nature of the locality, from the time when captured, and from the enlarged state of the testicles, there can be little doubt that this 
bird was breeding in the neighbourhood; and I have some reason for believing that the nidification of this species has occurred in another part of England." Mr. Hancock, who then further states that he has an egg of this species, taken in Northamptonshire, has since expressed to me some doubts upon the subject, having lately ascertained that the friend from whom he received the egg had in his possession also eggs not British.

Mr. Gould says that the nest of this species is supported like that of our reed warbler amongst reeds. The great depth of a nest which I have from the collection of Mr. A. Newton, would lead one to suppose that it must have been placed in an elevated position, and liable to be shaken by the wind. It is composed almost altogether of the fine flowering tops of reeds and other grasses an inch thick, bound round outside by their stalks and ribband-leaves.

The eggs are four or five in number. A variety in the collection of Mr. Salmon is tinted with light blue, sparingly spotted, and a good deal like the variety of the egg of the reed warbler at fig. 2. 
INSESSORES.

DENTIROSTRES.

\section{NIGHTINGALE. \\ Philomela luscinia. \\ PLATE XXXIII. FIG. I. AND II.}

Those who live too far north, or in the southern counties where its sweet notes are never heard, can have but little conception of the pleasure of which they are deprived, if they have never been so fortunate as to listen to the song of the Nightingale. I have many a time wished that I had yet to hear it for the first time, for although that delicious song, when heard in each succeeding year, produces a feeling of pleasure not to be expressed, it can never again excite the same thrill of enjoyment as at first.

. Doncaster had long been considered by ornithologists as the northern limit of the Nightingale. In the former edition of this work, I had the pleasure of extending its boundary line a little further, by stating that its song had been several times heard within four or five miles of York.

It is stated in the Zoologist by Mr. Robert Dick Duncan, that the Nightingale was heard in Calder Wood, in Mid Lothian, in the early part of the summer of 1826 , a remarkably warm season, one which must be well remembered, by every entomologist, as lavish in the production of many rare insects.

The singular, and apparently whimsical distribution of the Nightingale through the southern counties of Eng- 
XXXIII
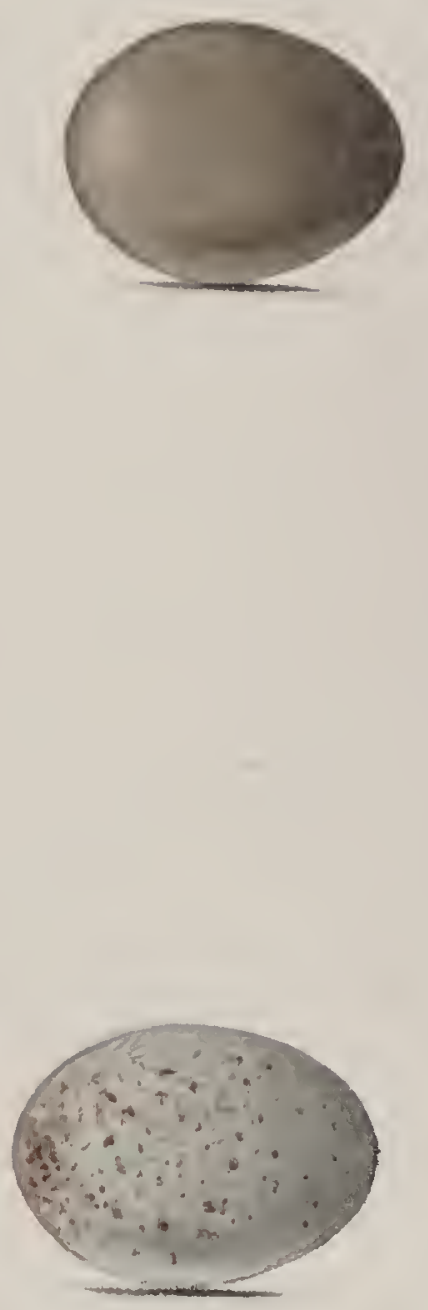

land, is one of those mysteries in natural history which has long puzzled the ornithologist, some of those counties which appear to him, in climate and in everything, best suited for their summer's sojourn, being entirely unvisited by them.

I have never at home, during the daytime, heard the song of the Nightingale in such perfection, so loud, so clear and joyous, as during a few days' ramble in the beautiful neighbourhood of Cintra; every coppice by the road-side, every orange-grove resounded with one loud burst of song.

The Nightingale makes its nest, like the robin redbreast, upon the ground, amongst the roots of trees, upon the stump of a felled tree, or upon a hedge-bank; its base is composed of loose herbage, rushes, and dry leaves; the nest itself is a thick matting of leaves principally oak, of rushes, and grass, lined with a thin covering of finer grass. The eggs are four or five, occasionally six in number; they are sometimes of a uniform colour, sometimes slightly mottled all over with a somewhat darker brown, and sometimes, though rarely, like the egg at fig. 2, from the collection of Mr. Bond; they are usually found towards the end of May or early in June.

It will be seen that the curious variety of the Nightingale's egg which I have figured, is as unusual in form as in colour. I have often observed that uncommon varieties of eggs, in colour, are also misshapen, both produced by an unhealthy bird. 


\section{BLACKCAP. \\ Sylvia atracapilla. \\ PLATE XXXIV. FIGS. I. AND II.}

The Blackcap builds its nest about the end of May, or beginning of June, in close and tangled thickets, in thorns, amongst brambles, and every species of low thick brushwood. In our gardens and pleasure-grounds it may be found in evergreens, and other thickly-leaved shrubs. It is formed outwardly of umbelliferous plants, twisted together with spiders' webs, bits of thread, and wool, becoming finer towards the inside, and mixed with the stalks and flowering heads of grasses, together with very fine roots, and a few hairs.

Though very slight and pervious, and apparently without the comfort of the thick, mossy, snug-looking nests of other birds, it is strong and compact, and in this alone differs from the nest of the garden warbler, which is more loosely put together, and in some instances formed of a larger quantity of materials.

The eggs of the Blackcap are four or five in number, and vary considerably, both in colour and in shape, being sometimes a good deal longer than either of the figures in the plate, sometimes almost round. The first of these figures represents the colouring which is most common; the second, a beautiful variety, which is not infrequent. There are many specimens smaller and lighter in colour than either of those drawn, and resembling the egg 
XXXIV
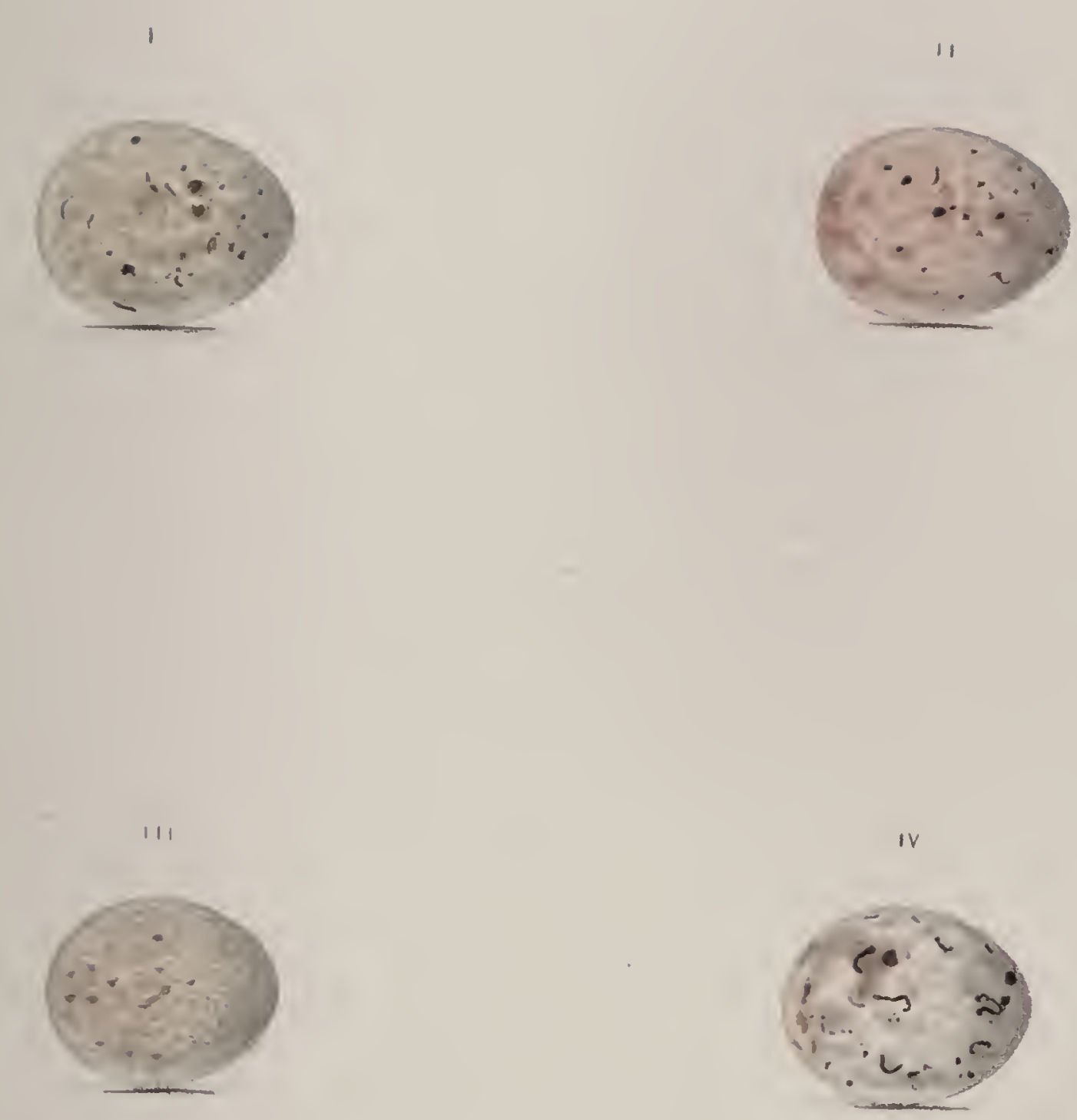

which is given as characteristic of those of the garden warbler.

We used at school to find a nest about once in a season, in which the eggs were altogether of a beautiful rose-colour, probably the produce of a young bird-for we always noticed that the nests in which they were found were unusually slight, and easily seen through, so much so, that we then considered them to belong to a different species. This pink variety, which I have seen much more beautiful, is represented at fig. 2 ; it is I believe peculiar to eggs of the Blackcap, and does not occur in those of the garden warbler.

Mr. Yarrell mentions this variety of the eggs, and supposes that the tint may be occasioned by partial incubation. This is not the case, incubation usually having the effect of deadening, rather than increasing the colouring of eggs. Last summer I had a nest of the Blackcap brought to me, the eggs of which were round and of a pure white. 
INSESSORES.

DENTIROSTRES.

\section{GARDEN WARBLER.}

\section{SylVia HORTENSIS.}

PLATE XXXIV. FIGS, III. AND IV.

WHen illustrating the eggs of the genus Curruca in the former edition of this work, it was my belief that the eggs of the Garden Warbler, although in some of the varieties very closely resembling those of the blackcap, were usually to be distinguished from them by their more beautiful and brighter colouring.

Mr. Henry Doubleday, of Epping, upon whose authority $I$ have the utmost reliance, assures me that the reverse is more frequently the case; "that the eggs of the Garden Warbler are generally smaller than those of the blackcap, and never so bright in colour;" but that the two often approach each other. I am, however, still of opinion that the eggs of the Garden Warbler, as well as those of the blackcap, have occasionally the same rich colouring. I have selected the eggs figured from a large series in the collection of $\mathrm{Mr}$. Bond, taken by himself; the beautiful variety at fig. 4, although from the nest of the Garden Warbler, may represent both species.

The nest of the Garden Warbler may be found at the same season of the year, and in all those places which I have mentioned as most likely to contain that of the blackcap. It is built, too, of the same materials-um- 
belliferous plants and grasses-lined with fine roots and a few hairs, but less compactly interwoven. The eggs are four or five in number. Mr. Yarrell has found the nest of this species "in a row of peas and pea-sticks in a garden, and once amongst some tares in an open field." 
INSESSORES.

DENTIROSTRES.

\section{WHITE'THROAT.}

\section{Sylvia Cinerea.}

\section{PLATE XXXV, FIGS. I. AND II.}

The eggs of the Whitethroat resemble more nearly those of the genus Salicaria, than of the more closely allied species of Sylvia; they are, however, very different from either, and have a character and colouring about them which is peculiar to themselves, and gives them, though individually differing a good deal both in size and marking, a specific distinction, which, amongst the numbers I have seen, could never be mistaken; they are always more or less tinted with green, and usually appear as though they were smeared and dirty. Some are much rounder than those which I have figured; some are slightly marked, except where the freckles are crowded into a zone round the larger end, others, though very rarely, are white, slightly marked with greyish spots.

In its nidification the Whitethroat closely resembles the other species of the same genus; the nest, though apparently slight and comfortless, is composed of materials so light, and at the same time so strong, that it is much more compact and firm than the more substantiallooking structures of the Fringillidæ. It is composed almost entirely of the stalks of umbelliferous plants, bound and tied together with spiders' webs, and bits of 


\section{$X X X V$}
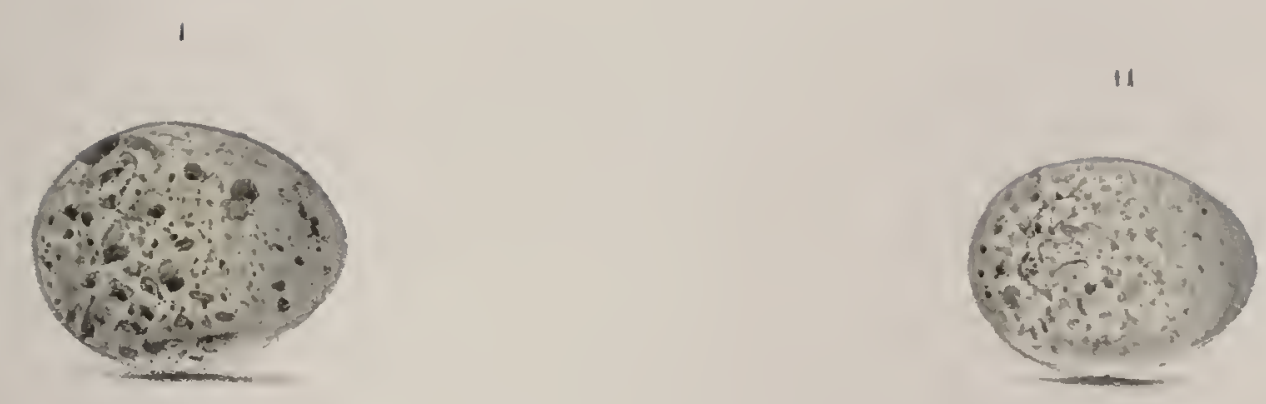

i)

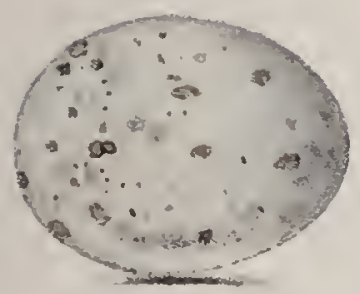

iv

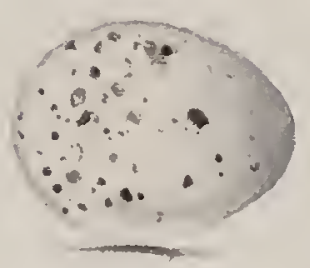



wool, and is generally lined with black horse-hair. It is usually placed in some of the rank herbage which is met with in the ditch of a hedge-bottom; in a low bush; in brambles; or a bunch of nettles which are even strong enough to support its weight. The eggs are four or five and sometimes six in number.

In Westmoreland, where the Whitethroat abounds, it is known by the name of Split-straw, from the fine strawlike materials used in the formation of its nest. 
INSESSORES.

DENTIROSTRES.

\section{LESSER WHITETHROAT.}

\section{Sylvia Curruca.}

PLATE XXXV. FIG. IV.

THE nest of the Lesser Whitethroat is found in situations similar to that of the common whitethroat; it resembles closely those of the three preceding species, and differs from them only in being constructed of rather finer materials; it is formed outwardly of umbelliferous plants, bound together with spiders' webs, pieces of hemp, or any such like material mixed, rarely, with bits of moss; the lining contains a few roots, but consists chiefly of the flowering heads of fine grasses, deprived of their seed, in lieu of the stronger stalks of grass of which the nests of the other species are composed. The eggs bear no resemblance to those of the common whitethroat, but are a good deal like some varieties of those of the blackcap; they vary little except in size, and in all the specimens I have seen, and they have been many, have the light ground-colour and clearly-defined markings of the Plate, and are not, like those of the other species, suffused over the surface with uncertain colouring: they are four or five in number, and are usually undergoing incubation about the middle of May. 
ORPHEUS WARBLER.

Syluia Orphea.

PLATE XXXV. FIG. III.

I HAVE been induced to figure the egg of this species for the same reason that $I$ have introduced that of the great sedge warbler, from a single instance of its capture in this country which I believe to be well authenticated.

The bird, which is now in the collection of $\mathrm{Mr}$. W. M. E. Milner of Nunappleton and was first recorded in the "Zoologist," was shot by Mr. Simpson during. the breeding season (July 6th), near the town of Wetherby. It is a female, and had been observed by him together with its black-headed mate, which was the means of attracting his attention by its peculiar warble and great resemblance to the well-known blackcap, and at the same time by its great difference in size. Mr. Simpson watched these birds together for upwards of a month before he shot the female, having no doubt that they were breeding in the neighbourhood, though unable to find their nest; being sufficiently acquainted with our common birds to know that this was not one of them, it was confided to the care of $\mathrm{Mr}$. Graham, a bird-stuffer at York, and being unknown to him, was again transferred to my friend Mr. Hancock, that he might determine its species. 
Temminck enumerates several singular localities as the nesting-places of this species; he says that they breed in bushes, frequently several of them in the same place; they also build in the holes of old walls and ruins, and under the eaves of isolated houses, in a heap of stones, and amongst rubbish, a habit very different to that of other species of Sylvia.

The egg figured, which is from the collection of $\mathrm{Mr}$. Walter, agrees well with those given by Thienemann, but is much larger than others which I have seen, said also to be the eggs of this species, which are more pointed at the smaller end, and have the spots of a deep brown chiefly at the larger end; some of these are like eggs of the green linnet. 
INSESSORES.

DENTIROSTRES.

SYLVIADAE.

\section{YELLOW WILLOW WREN, WOOD WARBLER.}

\section{Sylvia sibillatrix.}

PLATE XXXVI. FIG. III.

The Yellow Willow Wren is much more rare than the two allied species; its haunts are also different. Whilst the other two species are met with in every thicket and closely-tangled copse, this species frequents woods of a larger growth, and free from the thicker brushwood.

The nest is placed upon the ground in woods, under a tuft of grass; it is, like those of the willow wren and chiff-chaff, covered with a dome; it is, too, like them, composed of moss, dried grass, and dead leaves, but differs from them always in being lined with fine grass and hair, instead of feathers.

The eggs, which are usually seven in number, are, for the most part, similar to the accompanying figure; they are sometimes more oblong in shape, and thickly freckled all over with claret-coloured undefined spots. I have one, which is sparingly marked, and much like eggs of the chiff-chaff, but with larger spots.

I have often wondered at the difficulty which I have always experienced in obtaining eggs of this species, as well as those of the chiff-chaff. Neither of them are uncommon, especially in the south of England; 
and yet among the many eggs which have come before me, amongst which have been hundreds of those of the willow warbler, I have very rarely seen those of either of the other two species. In Westmoreland, after several summers of diligent bird-nesting, their eggs were not amongst our spoils. 
XXXVI.
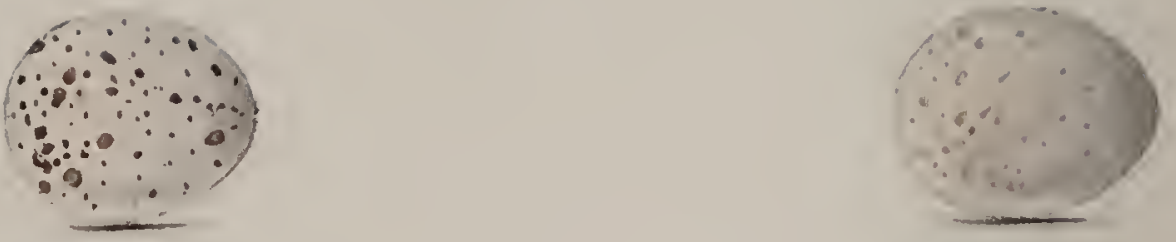

v

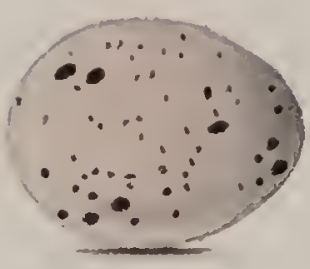


INSESSORES.

$S Y L V I A D E$.

DENTIROSTRES.

\section{W I L L O W W R E N,}

WILLOW WARBLER.

Sylvia TROCHILUs.

PLATE XXXVI. FIGS. I. AND II.

Much as I love all the dear birds of summer, there is not one the return of which I have yearly witnessed with so much pleasure as that of the Willow Wren; and however more highly the rich melody of some of the other warblers may be prized, there is a simplicity and a sweet cadence about the note of this species, which never fails to excite within me feelings of pleasure, which none but the lover of nature can either appreciate or understand, but which are to him amongst the chief enjoyments of his life.

The Willow Wren is one of the most abundant of the warblers, and almost every wood and copse is enlivened by its beautiful form and graceful motions:

"Thou fairy bird, how I love to trace

The rapid flight of thy tiny race!

For the wild bee does not wave its wing

More lightly than thine, thou fairy thing!"

It is, too, an inhabitant of more northern countries; and I shall not readily forget the delight I experienced on hearing its soft sweet note, whilst seated within the Arctic Circle upon one of the bleak isles of Norway.

The Willow Wren builds its nest upon the ground, sometimes in the midst of woods when not thick, but more commonly near their margin, or in open places, 
or by the side of those grassy drives which are cut through them. It may be found in hedge-banks where brushwood occurs, as well as amongst the long dry grass in young plantations. In shape the nest resembles that of the common wren, being arched over, and entered from the side; it is, however, much more fragile, and not easily moved entire; it is composed of dry grass and moss, with dead leaves, warmly lined with feathers. Amongst the many eggs which I have found myself, I have seen only the two varieties figured, and in about equal numbers; fig. 2 is less freckled than usual: the Messrs. Tuke have some which are, however, different, and which, in shape and markings, are more like eggs of the titmice. Dr. Neville Wood, in his "British Song Birds," quotes a letter, from Dr. Liverpool, describing the readiness with which the Willow Wren becomes sociable. To this $I$ can add a most interesting instance. To ascertain beyond doubt the identity of the two varieties of the eggs figured, I had captured, on their nests, several of the birds. Amongst these was one which I had carried home and confined during the night in a large box, and such was its tameness, that when I took it out the following morning and would have set it at liberty, it seemed to have no wish to leave my hand, and would hop about the table at which I was sitting, picking up flies which I caught for it.

In the autumn previous to their departure, the Willow Wrens frequent our gardens and orchards where they may be seen busily picking insects from the pea-straw and other vegetables, the young ones easily distinguished by their brighter yellow colouring; sometimes warbling a farewell song, but in a tone far different from their joyous carol in the spring, and so subdued that it is scarcely audible. 


\section{CHIF F CHAFF.}

\section{Sylvia RUfa.}

PLATE XXXVI. FIG. IV.

However monotonous the voice of the Chiff Chaff may sound when mingled with the rich melody of the various warblers, there is a time at which it brings with it a delightful welcome, when its cheerful sound bursts upon the ear as the first notice of the arrival of our feathered friends, just as the violet and the primroseharbingers of the "time of flowers"-are first rearing their beautiful forms upon the cold earth, to tell us that the woods will soon again be green, and that the chill, joyless winter is about to give place to the delights of summer. It comes to us before the insects have left their winter hiding-places, when there is not a green leaf to cover its graceful form.

The arrival of the Chiff Chaff usually takes place in March; and Dr. Neville Wood informs me that he has heard its note as early as the 5th of February. Montague likewise mentions January and February as its earliest appearance. It is generally sitting its eggs towards the end of May. The nest is very similar to that of the willow warbler; it is composed of dried grass, dead leaves, and moss; is covered with a dome, and profusely lined with feathers; it is, too, like the nest of that species, placed, most frequently perhaps, 
upon the ground, but unlike it, is, in many instances, raised above it, in a low bush. Mr. Henry Doubleday - I copy the information from Mr. Yarrell's "Birds"found a nest of this species formed externally of dead leaves, placed in dead fern, at least two feet from the ground. I once found one at the same height in some ivy against a garden-wall. The eggs are usually seven; and though in lightly-coloured varieties, much like some of the more distinctly spotted eggs of the willow warbler, are mostly marked with spots of a much deeper hue. An egg in the collection of Mr. Bond, is white, with the exception of some large purple spots near the broader end. 


\section{MELODIOUS WILLOW WARBLER.}

\section{Sylvia Hippolais.}

PLATE XXXVI. FIG. V.

For the first notice of this species as a bird new to Britain, I have to apply to the pages of the "Zoologist," where it is recorded by Dr. Plomley, that the melodious Willow Wren, the true Hippolais of Continental authors, was killed at Eythorne, near Dover, on the 15th of June, 1848.

It is abundant in Holland, and on the banks of the Rhine; its song is, I think, the sweetest carol I have ever heard, equalling, if not surpassing, that of the nightingale.

Although in every way most closely allied to the other willow wrens, it differs from them strangely in its nidification, and the colour of its eggs. Its nest is more like that of a Salicaria than of a Sylvia. It is without a dome, and, instead of being placed upon the ground, is frequently at a considerable elevation. $\mathrm{Mr}$. Rennie found one near Bonn, high up in the branches of a lilac tree. Naumann and Buhle, in their work on birds' eggs, say* that the nest is placed in the forked branches of lower trees, and on bushes more open than usual; also on side branches of the thinner

* I have to thank an old friend, the Rev. James Smith, of Monquhitter, for this translation from the German, which I have copied from the "Zoologist." 
trunks of trees, and more seldom on higher and slender branches at a distance from the trunk; also in gardens, in the tops of plum and other fruit trees, or in copses three to fifteen feet high, but not in thorns nor in dead hedges. The kindness of Mr. A. Newton has given me the pleasure of describing the beautiful nest of this bird from the original; as mentioned by others, it has much the appearance of a finch's nest in the greater quantity of materials with which it is constructed; but these materials are chiefly the same as those used by the other warblers, and are so light that the nest before me, with its walls an inch thick, would travel post for a penny. It is composed chiefly of umbelliferous plants and fine dry grass, strongly bound together by a quantity of wool, mixed with fine shavings from the bark of the birch tree, and bits of moss; the inside is of the flowering tops of grasses without the seed, roots of the finest kind and a few hairs. Outwardly the nest has much the appearance of that of the chaffinch, studded over with bits of white bark instead of lichens.

Mr. Rennie thus describes the nest found by him in Germany. "The frame-work is rather thick, made of dry grass stems, sewing thread, fine wood shavings, birch bark and small pieces of linen rag. The inside is very neatly lined with roots, hair, a few feathers and small locks of wool.

The eggs are four or five in number, and, though very different from our other warblers, have the same purple spots as those of the chiff chaff and similarly distributed. As far as I have seen them they appear to be very constant in their colour and marking. 

XXXVII
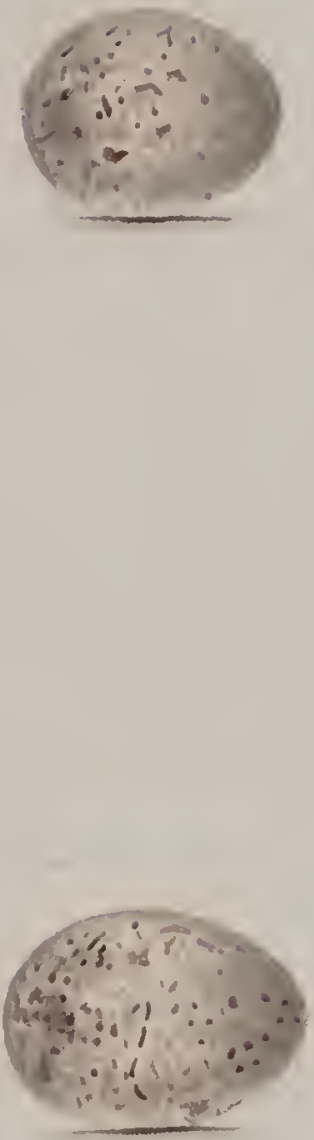


\section{DARTFORD WARBLER. \\ Melizophilus Provincialis.}

PLATE XXXVIr.

The Dartford Warbler is one of those birds which, although not unfrequent in a few localities, is nevertheless difficult to procure.

It breeds at no great distance from London; is plentiful near Godalming, and may be met with near Lyndhurst in the New Forest. Colonel Montague, who gives the following narrative, observed them near Kingsbridge upon a large furze common; he had watched three pairs of these birds on the 16th of July, two pairs of which, he says, "had young, evidently, by their extreme clamour, and by frequently appearing with food in their bills."

"On the 17th my researches were renewed, and after watching for three hours the motions of another pair, I discovered the nest with three young; it was placed among the dead branches of the thickest furze, about two feet from the ground, slightly fastened between the main stems, not in a fork. On the same day a pair were observed to be busied carrying materials for building, and, by concealing myself in the bushes, I soon discovered the place of nidification, and upon examination found the nest was just begun. As early as the 19th the nest appeared to be finished, but it possessed only 
one egg on the 21st, and on the 26th it contained four."

"The nest is composed of dry vegetable stalks, particularly goose-grass, mixed with the tender dead branches of furze, not sufficiently hardened to become prickly; these are put together in a very loose manner, and intermixed very sparingly with wool. In one of the nests was a single partridge's feather. The lining is equally sparing, for it consists only of a few dry stalks of some fine species of carex, without a single leaf of the plant. This flimsy structure, which the eye pervades in all parts, much resembles the nest of the white-throat." Two of these nests, each containing four or five eggs, are in the collection of Mr. Bond, and to him I owe the pleasure I derive from being able to describe this beautiful piece of workmanship myself. It is very different from those described by Montague, and is composed outwardly of umbelliferous plants, and moss, and bits of wool, exquisitely lined with the finest stalks and flowering tops of grasses without the seeds and as fine as the few horse-hairs mixed with them. It is an inch thick, and compactly built.

The eggs of the Dartford Warbler are very difficult to obtain. I have seen them in few collections, and was indebted to the kindness of Mr. Burney for specimens when busy with the former edition of this work; he took them near Oxford, after shooting the female from the nest, which was closely concealed in a thick covering of furze, and was composed of umbelliferous plants, and a small portion of moss, and was, as stated by Montague, a good deal like that of the whitethroat.

The eggs are four or five in number, and bear some resemblance to those of the whitethroat, as well as those 
of the reed-warbler; they differ greatly in size; one of those in the nest now by me is not unlike eggs of the grasshopper warbler; the spots are all crowded together at the larger end, the rest of the egg being very minutely sprinkled over with rufous dots. 
INSESSORES.

SYLVIADR.

DENTIROSTRES.

\section{GOLDEN-CRESTED WREN.}

\section{Regulus auricapillus.}

PLATE XXXVIII, FIGS. I. AND II.

This, the least of our British Birds, is very generally dispersed throughout the country, and may be met with from the most northerly part of Scotland and its islands, to the southern extremity of England; we saw it also whilst travelling through the pine forests of Norway. In activity and habit, when in search of insects, it resembles much the various species of titmice, and may be seen, like them, and frequently in company with the cole titmouse, suspended from the branches of trees in all those graceful and beautiful attitudes so peculiar to that tribe of birds. Its chief resort is in fir plantations, and its nest is usually placed in a tree of that species. It is most commonly suspended beneath the sheltering branches of the spruce fir-tree attached to some of the slender drooping twigs; of a nest thus suspended $\mathrm{Mr}$. Yarrell has given a nice figure in a vignette. It is sometimes built upon the upper surface of the branch; and I have also seen it, but rarely, placed against the trunk of the tree upon the base of a diverging branch and at an elevation of from twelve to twenty feet above the ground; here the nests are not uncommon in the cedars which adorn our neighbourhood, and during the last summer I had the pleasure of watching these tiny birds from the commencement to the last finish of a beautiful nest which 

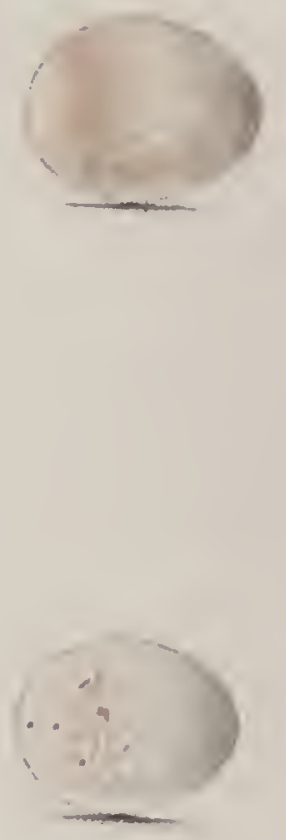

.

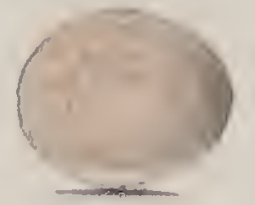



was placed in a branch of one of these trees only a few feet from my window. I have also seen a nest which was built in the centre of a low juniper and very little more than a foot above the ground. The nest is composed of the softest species of mosses interwoven with wool, a ferv grasses, dead leaves, and spiders' webs: with the latter material, together with the wool, it is twisted round and made fast to the branches of the tree from which it is suspended. It is lined with a quantity of feathers, those of the small birds being very appropriately selected to form the interior of this tiny dwelling. The eggs vary from seven to eight which is the number most frequent, to ten or even eleven; their commonest colouring is shown by the first figure, the second represents a variety not uncommon.

I have found the eggs of this species fresh in May and June; Mr. Selby states that he has known full-fledged young ones as early as the third week in April.

The nest, which I have mentioned above from the low juniper, contained eggs of a very singular variety, which, instead of being, as they usually are, of an oblong form and closely freckled all over with rust-coloured markings, were, like those of the willow wren, nearly round, and, like them and eggs of the marsh titmouse, sparingly spotted with red-brown. 'To satisfy my doubts both as to the nest and eggs the bird was caught and examined. 
INSESSORES.

SYLVIADAE.

DENTIROSTRES.

\section{FIRE-CRESTED WREN.}

\section{Regulus ignicapillus.}

PLATE XXXVII. FIG. III.

THE existence of the present species in this country was first made known by the Rev. L. Jenyns; other specimens have since been secured, and will most likely continue to be met with now that the separate identity of the two species has been pointed out. The Rev. E. H. Browne has watched this species during the summer near his residence at Blo Norton, in Norfolk, and has no doubt it breeds there.

In its nidification and number of its eggs the Firecrested Wren closely resembles the preceding species. Mr. Yarrell mentions that M. Vieillot found a nest of this bird near Rouen, which was suspended under the branch of a tree like that of the other species, and contained five eggs. 

XXXIX
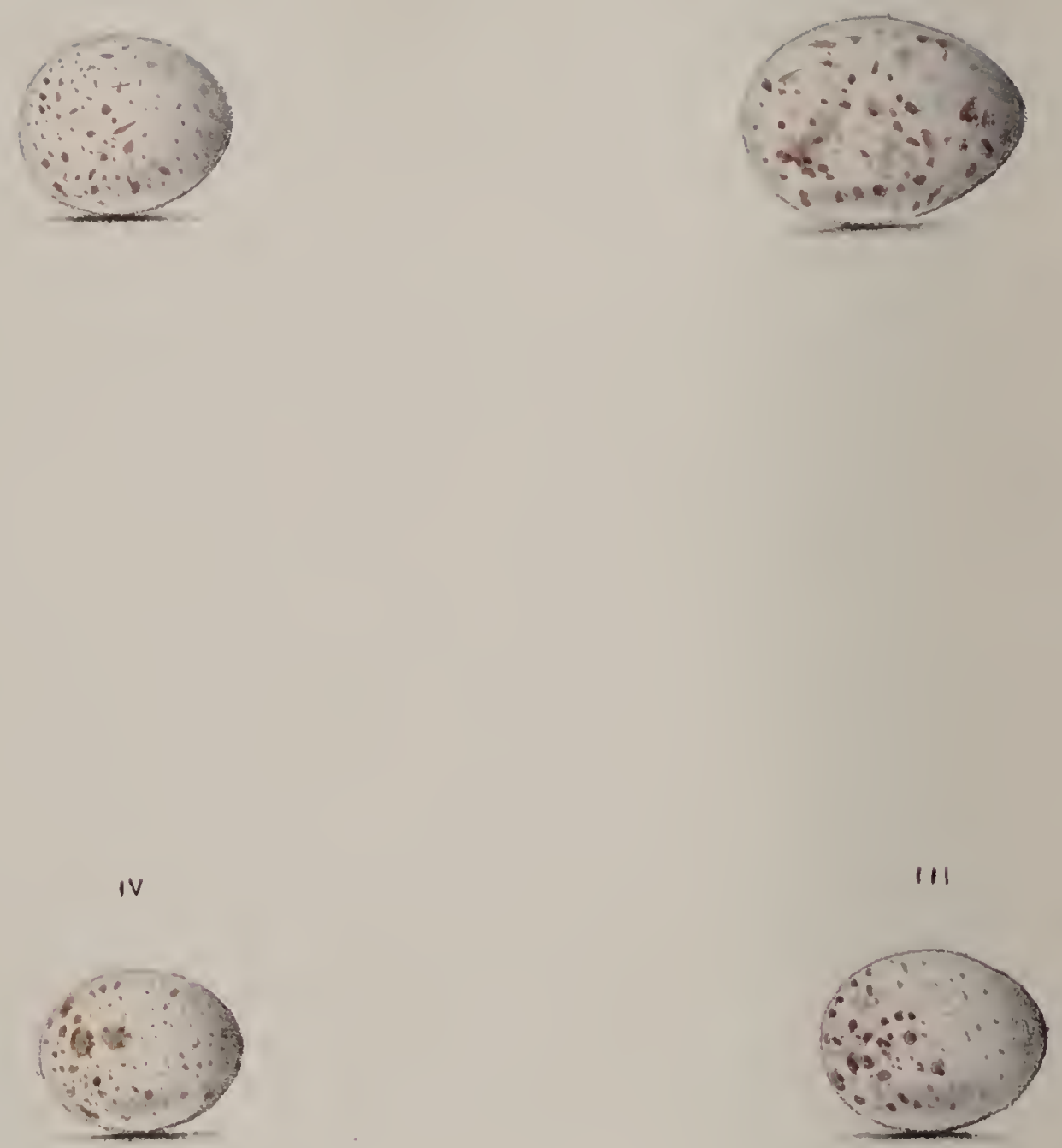


\section{GREA'T' 'I'TMOUSE,} OX-EYE.

\section{Parus major.}

PLATE XXXIX. FIG. I.

There are none of our birds to which we are more indebted for amusement and companionship than the Titmice. They are with us the year through and supply the place of the truant summer-visitors which have left us. Although deprived of song, there is still something most agreeable in their gay, cheerful, and oft-repeated notes. The constant chatter of the bluecap, the deep bass voice of the marsh titmouse, and even the monotonous spring-pipe of the greater titmouse, are all sounds highly pleasing to the lovers of nature. In activity and the beauty and gracefulness of their actions they are surpassed by none; no place is hidden from their researches; they are perfect mountebanks, and it seems to matter little to them whether their heads or their heels are uppermost; dancing at one moment in antics round the branches of a tree and at the next hanging suspended from its most slender twigs. They are some of the most prolific and consequently most numerous of our British Birds.

The Great Titmouse breeds in the holes of trees: $\mathrm{Mr}$. Yarrell says it will also sometimes make use of the deserted nest of a crow or magpie for that purpose. The nest is composed of moss and feathers, with 
some hair; its eggs are, however, sometimes laid upon the fine particles of the rotten wood alone; they are from seven to eleven in number and are exceedingly similar in all respects to the eggs of the nuthatch; they vary only in the number and intensity of the markings. 


\section{BLUE TITMOUSE.}

BLUECAP, TOMTIT, BILLY-BITER.

\section{Parus caruleus.}

PLATE XXXIX. FIG. II.

OuR well-known friend the Bluecap is the most numerous of his kind, and notwithstanding the absurd and cruel clamour that has been raised against him, and although he has long been outlawed, and a price set upon his guiltless head, he is of a race still sufficiently numerous to rid us of countless insects, and to heap benefits upon us in return for all the persecution that he has met with. He is a brave little fellow; and when the severity of winter has driven him, together with his companion the great titmouse, to seek for shelter under our walls and evergreens and he is pinched with hunger, he will boldly enter any trap that may be set to catch him. It is thus in our gardens that he may be seen, closely prying into every corner, and diligently destroying thousands of insects in their winter quarters; and though we may follow him in his search, and see the buds of promise from our trees strewed behind him, he has been destroying them to get at the lurking enemy within, which, had it been permitted to live till the following spring, would have wrought us tenfold evil.

Nothing that other birds will eat seems to come amiss to him; he is very fond of a bit of carrion; and in 
order to humour his penchant, I have often nailed small pieces of raw meat against the trees in winter, and amused myself when storm-stayed in the house, by watching his enjoyment. Obstinacy is a remarkable trait in his character, and when he has once set his mind upon some particular spot in which to make his nest, he is only to be driven from it by force and oftrepeated failure. I remember one, which had taken a fancy to build its nest in the hole under the handle of the garden pump, and it was not till its labour had been destroyed for many successive days that it abandoned the attempt. When once in charge of his eggs or young ones, he will stoutly defend them against all intruders, first giving you warning that he is on the defensive by a snake-like hissing noise, and if you obtrude your fingers, by biting them with all his might; and should you cruelly deprive him of the object of all his care, and forcibly eject him from his home, he will still return to its deserted walls for many days to deplore his loss. Of this his attachment to some particular spot, $\mathrm{Mr}$. Heysham, of Carlisle, has kindly supplied me with the following most interesting instance.

"A few years ago, when upon an entomological excursion, wishing to examine the decayed stump of a tree which was broken to pieces for that purpose, and the fragments dispersed to a considerable distance by a severe blow, a Blue Titmouse was found sitting upon fourteen eggs, in a small cavity of the root, and notwithstanding. the above severe shock, it remained immovable, till forcibly taken off the nest."

"Early this spring a pair had taken possession of a hole in a tree where the pied-flycatcher had regularly built for the last four years, and, being anxious it should continue to do so, the nest and eggs were removed, the 
latter, to the number of sixteen; in defiance of all these annoyances the female still kept possession of the hole, where I saw it repeatedly afterwards for several weeks, sitting upon the bare rood."

It will be seen, too, by these narratives that the Blue Titmouse is the most prolific of our birds.

Until I had the authority which I have just quoted, I have always been accustomed to receive with jealousy and caution any of those reports in which some seem so much to delight, regarding the number of eggs laid by some of our smaller birds, never, in pretty extensive bird-nesting experience, having once met with the nest of any of our Insessorial birds containing more than eight eggs, and I think it most probable that when the eggs are more numerous, they are the produce of more than one bird; and this supposition is supported by the observations of $\mathrm{Mr}$. Horsfall with regard to the longtailed titmouse.

The Blue Titmouse builds its nest of grass, moss, hair, and feathers; it is placed in the holes of trees and old walls, and small though the bird be, it is not easy sometimes to credit one's sight, through how very small an aperture it can pass. The eggs are most frequently seven or eight, although at times amounting to the unusual number of sixteen. 
INSESSORES.

PARIDA.

DENTIROSTRES.

\section{CRESTED TITMOUSE.}

\section{Parus cristatus.}

PLATE XXXIX. FIG. III.

The Crested Titmouse has now for some years been met with breeding in several of the pine forests of Scotland.

Mr. Hancock, of Newcastle, who has kindly sent me the following information with the egg which I liave figured, found several of their nests, during an ornithological excursion in Scotland, in the woods of Murrayshire. "About the middle of April they were only in process of building, but by the 6th of May, when the nests were taken, the eggs were five in number; whether this is the full compliment or not I am not prepared to say. The nests were all placed in similar situations in holes of old stumps of trees from three to six feet above the ground. The nest is composed of rabbits' or hares' down, a little moss, and a few feathers. At first sight it appears to be composed entirely of down, but on close examination the materials are seen to be as above."

In its actions and habits the Crested Titmouse resembles the blue titmouse so closely, that, when in the branches of a tree above your head, it is only by the crest that you can distinguish it. It is alike noisy, and always on the move.

I have watched them for hours, as, in busy pursuit of 
insects, they thronged the branches of some noble English-looking oak-trees, which adorn the outskirts of the forest at Kissingen, in Bavaria. They were equally abundant amongst the pine-trees; and although it was too late to obtain their eggs, I had the pleasure of discovering one of their nests and of thus learning something of their nidification.

When trees are felled in the forest, their trunks are left standing about two feet above the ground, and in the decayed wood of one of these a hole was scooped to contain the nest of which I have spoken, just such a situation as would have been chosen by the cole-titmouse. The nest was of dry grass and moss, and lined with feathers, and contained five full-fledged young ones which scrambled out of the nest as we began to examine them. This species is said to lay from seven to ten eggs. Mr. Hancock's nests each contained no more than five eggs, and the one mentioned above only five young ones. 
IN'SESSORES.

PARIDAE.

DENTIROSTRES.

\section{COLE TI'TMOUSE.}

\section{Parus ater.}

PLATE XXXIX, FIG. IV.

The Cole Titmouse breeds, like all the preceding species, in the holes of trees, but with this difference, that the hole chosen by it is usually at a less elevation from the ground than that adopted by the others. It seems indeed to prefer just those places in which its young must be exposed to the greatest destruction, holes which are very near the ground, or even below its surface. In this neighbourhood the Cole Titmouse is more abundant than I have ever seen it elsewhere. For several years in succession a pair of them have reared their young ones in a hole at the base of a venerable oak tree, and Mr. A. Newton tells me, that, as far as he has observed them, they seem to prefer a subterranean nursery for their young, and that he has known the nest upwards of a foot below the surface of the ground in the decayed stump of a tree which had been cut down to a level with the earth. Its nest is sometimes built, as mentioned by $\mathrm{Mr}$. Selby, in the entrance of a mouse-hole. It is composed of moss, wool, hair, and feathers. Mr. Salmon has observed that the Cole Titmouse seems to have a great partiality for rabbits' fur, with which it always lines its nest, when in the neighbourhood of a warren, and even, when at a distance from one. The eggs are from six to eight in number. 


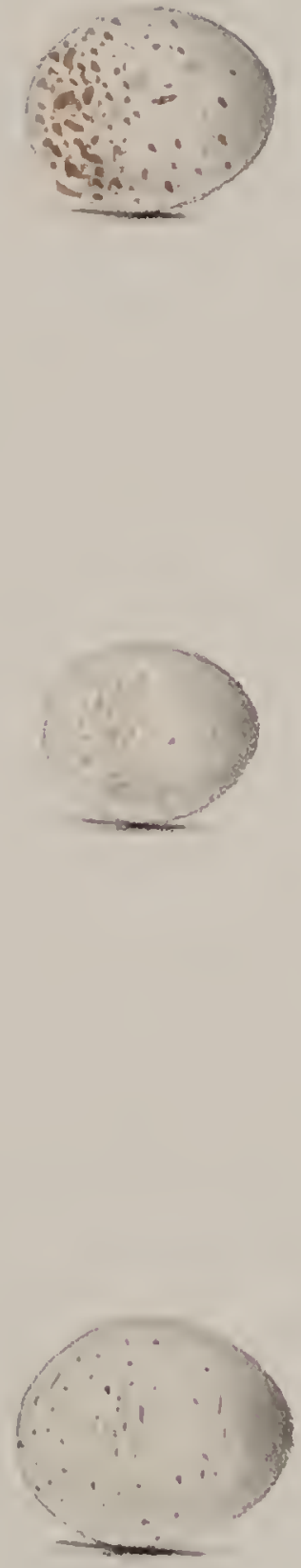


\section{MARSH TITMOUSE.}

Parus palustris.

PLATE XIL. FIG. I.

Considerable pains is taken by the Marsh Titmouse in hollowing out a suitable cavity for its nest; whilst excavating which, Colonel Montagu has watched it carefully conveying away the chips to some distance in its bill. It is, as its name implies, fond of low marshy districts, and, as Mr. Yarrell observes, usually makes choice of a pollard and decayed willow, in which to rear its young ones. The nest is made with more care than those of the preceding, and is formed of moss, grass, and lined with the soft down of the willow. Mr. Gurney has known this species to make its nest like the cole tit, in a rat's hole, which was in a closely-mown lawn.

The eggs are seven or eight in number; they resemble very closely those of the blue titmouse; the spots are, however, usually larger, and the form of the egg is rounder and often much like those of the willow-wren. 
INSESSORES.

DENTIROSTRES.

\section{I.ONG-TAILED TITMOUSE. BOTTLE TIT.}

\section{Parus caudatus.}

PLATE XL. Fig, II.

Amongst the many curious and ingeniously-constructed nests, which we have seen and admired as the workmanship of the bright birds of other climes, there is not one which can surpass in beauty that of our own native Long-tailed Titmouse. It is in every way perfect as the safeguard of the tiny beings that are to be reared under its protecting roof and fostered by its warmth, covered in and defended as it is against every wind that blows, and formed of the softest materials. Its exterior is of green moss closely and compactly woven together throughout with wool and the nests and webs of spiders, and studded and coated over outside like the nest of the chaffinch with pieces of grey lichen; its inside is so thickly lined with feathers as to obtain for it, in some parts of the country, the name of feather-poke. Mr. Selby, when describing the nest of this species, speaks of a double hole, one for ingress, the other for egress, as if a common occurrence. I have never lost an opportunity of examining a nest, and have only once seen the second hole, and the nest I speak of was shown as a curiosity in Mr. Empson's museum at Bath. The holes were larger than usual, and opposite each other. 
I have never met with the Long-tailed Titmouse so common, or seen them so often as to destroy the novelty and interest which their appearance never fails to excite, as they come flitting across my path in rapid succession.

They are most sociable little beings, and except during the breeding-season, are rarely seen alone: united in families during the winter months, they may be seen sometimes passing from hedge to hedge, following each other in a long string, in restless and scarcely-interrupted flight.

With the exception of the species of Regulus the eggs of the Long-tailed Titmouse are smaller than those of any other British bird; they are from seven to ten, and sometimes as many as sixteen in number. I state this upon authority which I believe to be good, never having inyself seen more than seven in the same nest. The spots are sometimes altogether absent from some specimens or scarcely visible.

Upon finding the nest of almost every bird, we may predict with tolerable certainty the number of eggs it will contain, provided the bird has done laying; but with the blue and Long-tailed Titmouse it is far different; their eggs vary from seven or eight, to twice that number, and even more; I have found the nest of each of them with seven eggs only, and hard sitten, and I believe this to be the greatest number laid by one bird; and in confirmation of my opinion I copy the following curious account by Mr. Horsfall, in the "Zoologist." "Mr. Yarrell, in his account of this bird, states the number of eggs to be ten or twelve, and occasionally a larger number: I suspect where the greater number is found, there will be more than one pair of birds attached to the same nest. I have known several instances 
where a considerable number of birds have had the same nest in common. In one instance there were nine, and I found the nest whilst the birds were lining it with feathers, and if I remember rightly, most of them were engaged in conveying the feathers. During the time of incubation two usually sat on the eggs, the number of which I never discovered, for fear of disturbing the nest, which was built in a very singular position, being placed in the fork of a large oak tree. I assisted in capturing five of the parent birds, belonging to another nest, whilst feeding their young, and two or more were left behind."

The nest of this species is placed most frequently, perhaps, in the centre of a thick bush, not uncommonly in whin or furze. I have seen it, however, in a very different situation, far from the ground, upon the main branches of the oak; and I suspect that it might be more frequently met with there than elsewhere, were it not from the great difficulty in discovering it.

In each of the instances in which I have found it, it was by having my attention directed to the spot by the frequent flight of the birds in that direction, and so closely did the nest resemble a portion of the tree, that it was not detected till I had seen the birds go inside; upon climbing to the spot I found that the nest was built upon one of the main boughs which the base of it partly spanned, without any support from the smaller branches. 
DENTIROSTRES.

\section{BEARDED TITMOUSE.}

\section{Calamophilus biarmicus.}

PLATE XL. FIG. III.

The Bearded Titmouse is either so sparingly dispersed in most parts of the country, or is, in those fenny districts where more abundant, so difficult to approach, that but little is known of its habits, except by those who for that purpose have made a visit to its retreats, which are chiefly in the marshy districts of the counties of Norfolk, Suffolk, Huntingdon, Cambridge, and Lincoln.

Never having myself had the pleasure of seeing it in its native haunts, I copy the narrative of an acute observer. Mr. Hoy thus writes in the pages of the "Magazine of Natural History:"-"The borders of the large pieces of fresh water in Norfolk, called Broads, particularly Hickling and Horsey Broads, are the favourite places of resort of this bird; indeed it is to be met with in that neighbourhood wherever there are reeds in any quantity, with fenny land adjoining. I have found them numerous during the breeding-season on the skirts of Whittlesea, and they are not uncommon in the fenny districts of Lincolnshire. It begins building in the end of April. The nest is composed on the outside with the dead leaves of reed and sedge, intermixed with a few pieces of grass, and invariably lined with the top of the reed, somewhat in the manner of the nest of the reed-wren, 
but not so compact in the interior; it is generally placed in a tuft of coarse grass, or rushes near the ground, on the margin of the dykes in the fen; also sometimes fixed among the reeds that are broken down, but never suspended between the stems; the eggs vary in number from four to six, rarely seven." Mr. Yarrell says: "A few years since I obtained two nests from the parish of Horsey. These were both placed near the ground, being sustained only an inch or two above the surface by the strength of the stems of the coarse grass upon which they were fixed. Each nest was composed entirely of dried bents, the finer ones forming the lining." 

XL]
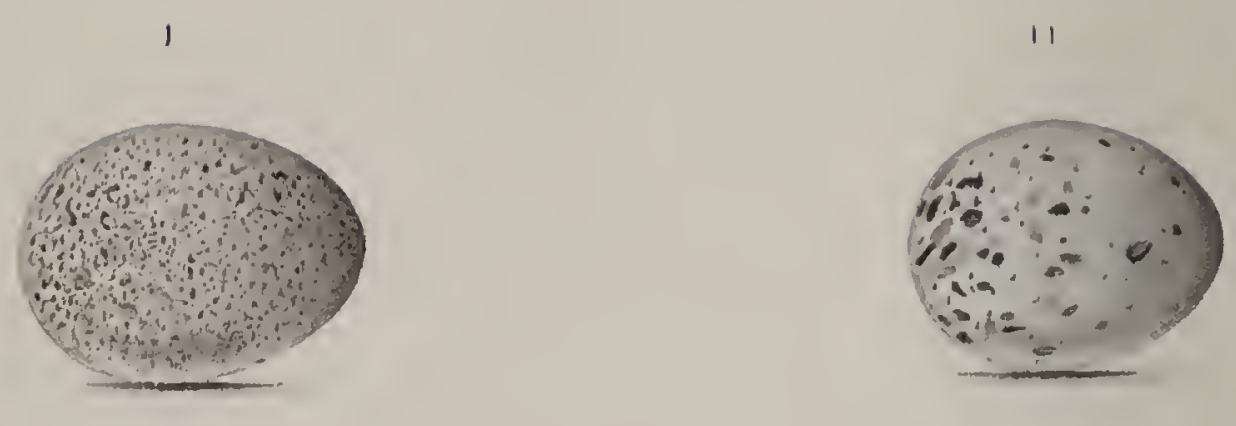

111
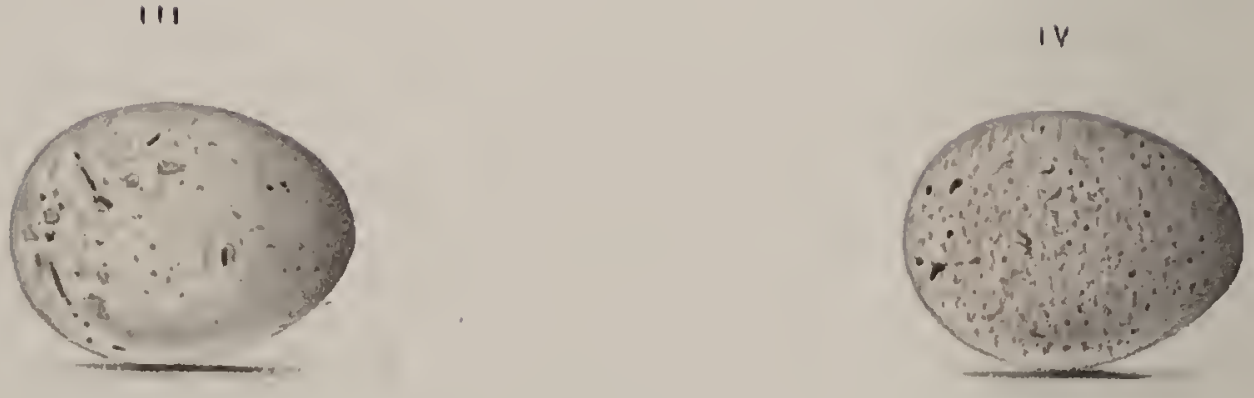


\section{PIED WAGTAIL.}

\section{Motacilla Yarrellit.}

PLATE XLI. FIGS. I. AND II.

Although not at present prepared myself to adopt as distinct species the two Pied Wagtails of Mr. Gould, I have yet felt unwilling to reject the name proposed by him as a tribute to $\mathrm{Mr}$. Yarrell, since it may yet be proved more satisfactorily that $\mathrm{Mr}$. Gould's species are more than varieties. I have, therefore, figured eggs of both birds, since they are believed by many Ornithologists to be distinct.

The Pied Wagtail builds its nest in the holes of walls, bridges, and out-houses, and on the broken banks of rivers upon the ground. Mr. Yarrell says that it is frequently fixed in the side of a woodstack or hayrick, and occasionally occupies a cavity in a peat stack, or wall of turf sod.

Mr. Jesse mentions a remarkable instance of a bird of this species, which built its nest in one of the workshops belonging to Mr. Cox of Taunton, and, although the room was occupied by braziers, and the noise loud and incessant, yet in this strange place did the old birds persevere in hatching their young ones.

The nest of the Pied Wagtail is composed of roots and grasses, lined with finer roots and hair.

The eggs, which are from four to five in number, vary 
very considerably both in size and colour. Fig. 1, which is most characteristic of the species, scarcely differs from egg's of Savi's warbler. Fig. 2, which is less common, would with difficulty be distinguished from eggs of the house-sparrow. 


\title{
WHITE WAGTAIL.
}

\author{
Motacilla alba.
}

PLATE XLI. FIGS. III. AND IV.

The White Wagtail, the M. alba of Linnæus, and the common pie-bald wagtail of the Continent, is not an uncommon visitant of this country, where it also remains to breed. That it is specifically distinct from $M$. Yarrellii, I greatly doubt. There is nothing in the appearance of its typical eggs by which they can be known from those of our more common bird. The most characteristic eggs of both are thickly freckled throughout with minute spots and streaks of grey or brown, the eggs of both differ much in size; some of those of the White Wagtail sent from Sweden by Mr. Wolley, are one-third less than those I have figured, whilst other specimens, kindly sent me by $\mathrm{Mr}$. Carter of Manchester, are very large; the one drawn at fig. 3, with three others from the same nest, is not unlike eggs of the green linnet, and differs from any eggs I have seen of $M$. Yarrellii. Mr. Carter caught the female upon the nest, that he las sent me, which was placed in a reed stack on the fen near Whittlesea Mere where he saw the birds in great numbers for two successive summers. He has also seen them near Manchester, and observed about a dozen at a time in a potato field near Conway. He has generally met with them in ploughed fields, and rarely by the side of water. He says:- "I have also seen them at Turton, a small village 
between Bolton and Blackburn, and though there is a large lake of water in the neighbourhood in which I have frequently fished, I never saw one of these birds by its edge, but frequently the pied."

Mr. Carter's nest is ill constructed, composed of a large quantity of very coarse grass and roots, and lined with wool and hair mixed together.' A nest from Holland, sent me by Mr. A. Newton, is much more symmetrical. Outwardly it is composed of the stalks of plants, dry grasses, bits of moss, and a large quantity of fine roots, followed inwardly by wool, and then thickly lined with hair; the central cavity is large. 

XIIII.

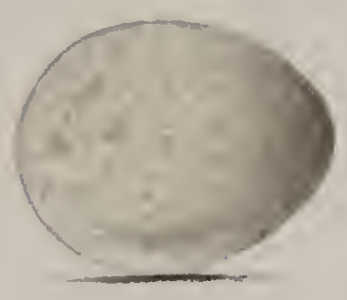

0

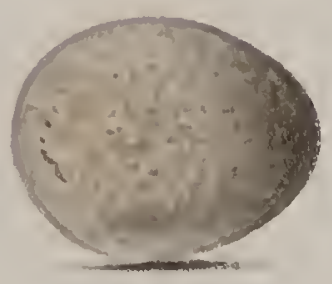




\section{GREY WAG'TAIL.}

\section{Motacilla boarula.}

PLATE XliI. FIG. I.

The nest of the Grey Wagtail may be found in most of the situations chosen by the pied wagtail; in an old wall or bridge near a stream of water, but is more frequently met with upon the ground than that of the pied species. In its materials it is also nearly similar to the last, being composed of dry grass and roots, with sometimes a little moss or wool, and lined with hair.

The Grey Wagtail is, comparatively, a rare bird, and is chiefly confined to the north of England during the breeding-season. I have taken its nest and eggs in Westmoreland; from Mr. Heysham, of Carlisle, I have others; and also-together with a nest beautifully lined with white hair only-from Mr. Leyland, of Halifax, who meets with them in his own neighbourhood every year.

This beautiful bird is very abundant in Madeira; I used to meet with it everywhere upon the margin of the numerous levadas, or water-courses, by which the country is intersected for the irrigation of the vineyards.

The eggs of this species are usually very slightly coloured, but are sometimes much darker than the Plate. They are usually four or five in number, but occasionally extend to six. 
INSESSORES.

MOTACILLIDE.

DENTIROEIRES.

\section{GREY-HEADED YELLOW WAGTAIL.}

Motacilla flava.

PLATE XIII. FIG, II,

Since the marks of difference which distinguish this species from the common yellow wagtail, with which we are so familiar, were first pointed out by Mr. Gould, several specimens have been met with in this country.

My friend Mr. Henry Doubleday was the first to give it a place as a British bird, since which others have been killed near London, in Suffolk, Northumberland, and in Scotland.

This species, being the true Motacilla flava of the Continental naturalists, must retain the name. It is, therefore, proposed that we should for the future know our Yellow Wagtail, which has become familiar to us under the name of M. Alava, by that of Motacilla Rayi.

To the late Mr. Hoy I am indebted for a nest, and a large series of the eggs of this species collected by him on the Continent, together with the following information :-

"The $M$. Alava arrives about the middle of April, and is then seen following the plough in search of insects. It differs from the yellow wagtail in its breeding-places; whilst our species most commonly makes its nest in dry situations in corn-fields, the continental species prefers low wet lands, placing its nest upon the ground in marshes, by the side of ditches in meadows, on the 
borders of inland pools and meres, and often on the boggy parts of heaths."

Whenever we noticed this species in Norway, and we did so in several instances, it was always upon heaths and marshes so wet and boggy, that it was with difficulty we could explore them.

The nest of the Grey-headed Yellow Wagtail is formed of coarse grass, and those mosses which grow in wet situations, strengthened by pieces of heath, and lined with fine grass and roots, moss and hair.

Some of the eggs scarcely differ from those of our yellow wagtail; they, however, go through a greater variety of colouring, and are frequently much lighter than the figure, and sometimes a little darker. 
INSESSORES.

MOTACILLIDE.

DENTIROSTRES.

\section{RAY'S WAGTAIL.}

YELLOW WAGTAIL.

Motacilla Rayi.

PLATE XLII. FIG. III.

The Yellow Wagtail usually builds its nest upon the ground, in fields of peas, or green corn, or on a naked fallow. I have found it, too, upon a ledge of earth on the bank of a river, and in the hole of a wall by the side of water. The nest is composed of dry grasses, roots, bits of moss or wool, and is lined with the finer grasses and roots and a few hairs. Mr. Newton tells me that nests of this species vary much in their construction; that "of two nests taken on the same day and within a few yards of each other, one is composed of green moss and grass, lined with rabbit's down, the other entirely of grass, and lined with fine roots." The eggs are commonly four or five in number, occasionally six; they are usually somewhat less than the eggs of the grey wagtail which they sometimes resemble; they are more like those of the grey-headed yellow wagtail, and it would be very difficult to identify them if once mixed with eggs of the sedge-warbler which they closely resemble in colour, as well as in being usually marked with a black waved line across the larger end. 
XLIII.
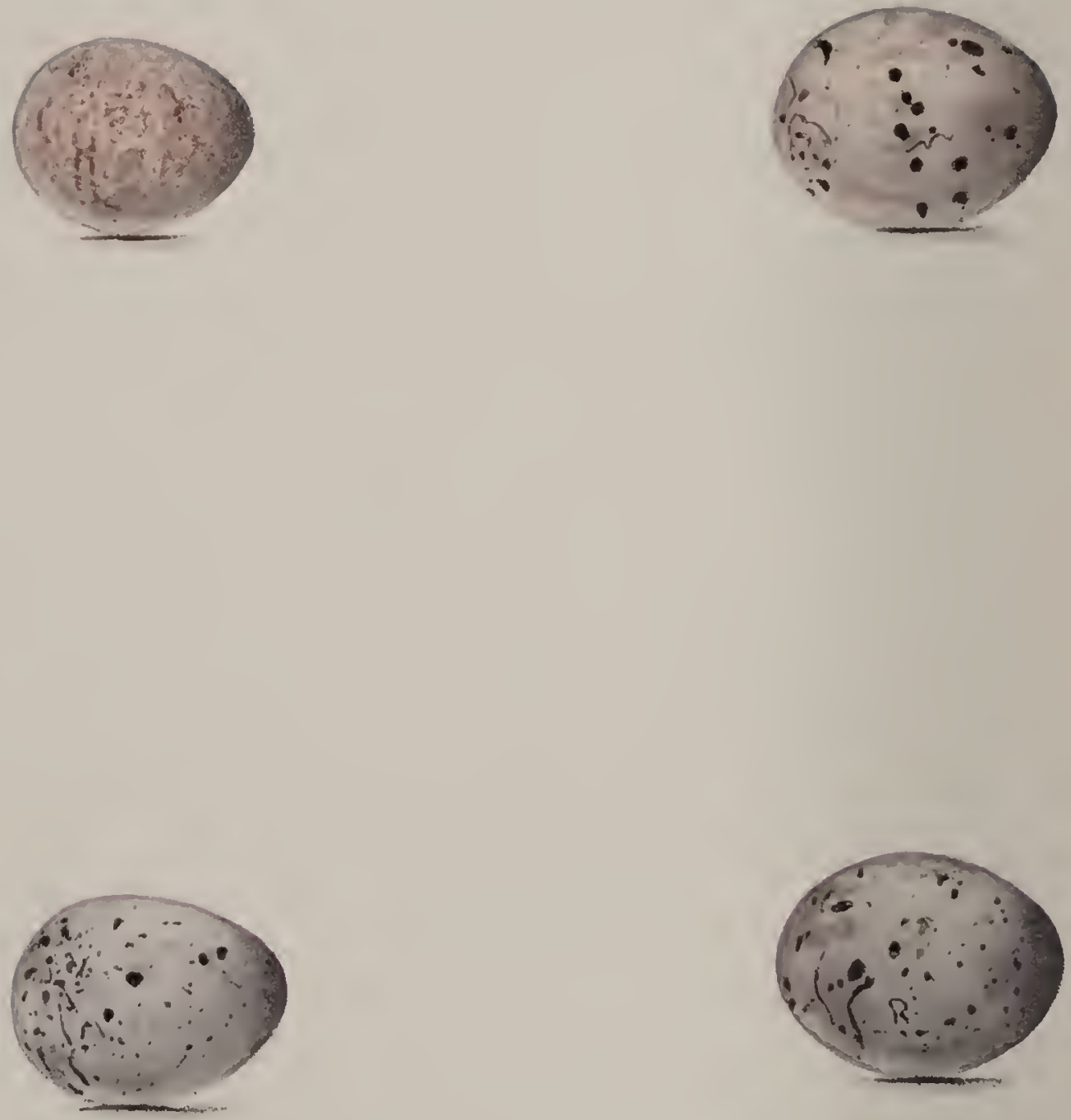


\section{TREE PIPIT.}

Anthus arboreus.

PLATE XLIII.

Amongst our land birds there is no species the eggs of which present so many, or such distinct varieties as those of the Tree Pipit. No one would at first believe them to be eggs of the same species; and it was not till I had captured the bird upon each of the varieties, and also received them from Mr. H. Doubleday similarly attested, that I felt satisfactorily convinced upon the subject.

Of the varieties figured, all are easily procured. I have taken them all in abundance when I was at scliool. The first figure is the most common.

In woody countries the Tree Pipit is very abundant, especially in Devonshire, Somersetshire, and some parts of Cumberland; differing in this its choice from the very closely-assimilated species the titlark, which, though it may be met with in the more cultivated and woody districts, is far more abundant on moors and open heaths, where it is followed by the cuckoo.

The nest of this species is composed chiefly of dry grass, mixed with moss, lined with finer grasses, and sometimes a few hairs. It is placed upon the ground, rarely far distant from trees or brushwood, and is frequently found in woods and plantations by the side of a drive or foot- 
path. Mr. Neville Wood, in his book of "British Song Birds," mentions an instance, the only one of which I have heard, of its having been found in a low bush.

The favourite resort of the Tree Pipit is a grassy bank on the margin of a wood, especially if ornamented by a few single trees on the branches of which it delights to perch. In such a situation you are sure to find its nest and eggs, if towards the end of May, or during the month of June; the eggs are four or five in number, and in their spotted varieties seem to represent and form a connecting link with those of the buntings. 

XLIV.
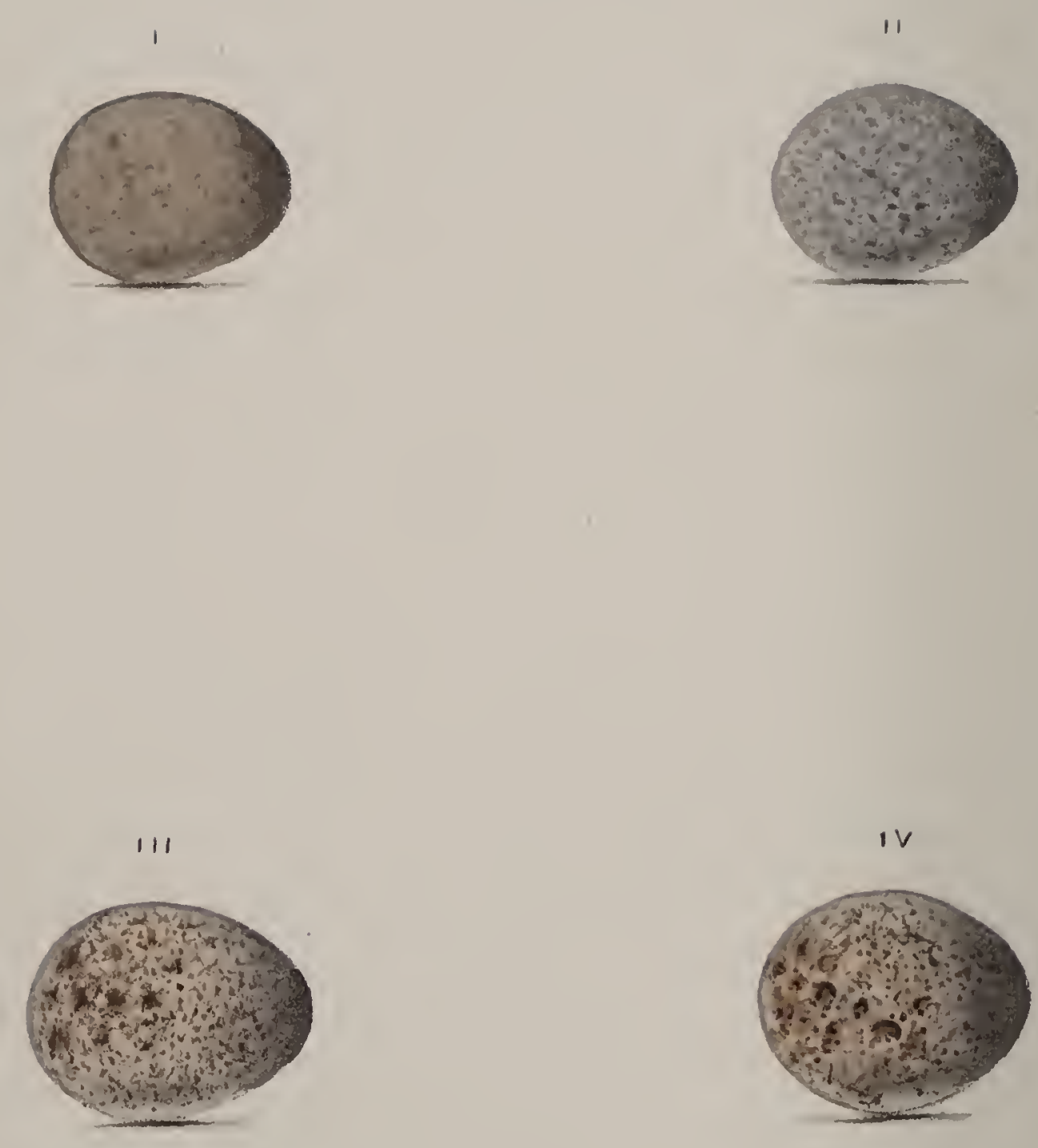


\section{MEADOW PIPIT.}

TITLARK.

\section{Anthus pratensis.}

PLATE XLIV. FIGS. I. AND II.

The eggs of the Meadow Pipit are less subject to variety than those of the other species, not often differing much from the sombre colouring of fig. 1, except in the intensity of tint; some are less strongly freckled throughout, whilst others are marked with a distinct zone of deeper colour towards the larger end. The variety at fig. '2, from the collection of $\mathrm{Mr}$. Bond, is seldom met with. I had one very distinct and remarkable variety, not unlike some eggs of the pied wagtail.

The Titlark builds its nest in meadows and pastures, but is more partial to the margins of heathy moors. On those which border the lake district of Cumberland and Westmoreland, it is very abundant; and the cuckoo, which seems to have a partiality for its nest, is there more numerous than I have ever seen it elsewhere. The nest is composed entirely of grass, finer towards the inside, and contains four or five eggs. 
TNSESSORES.

ANTIIID AE

DENTIROSTRES.

ROCK PIPIT.

ROCK LARK.

\section{Anthus aquaticus.}

PLATE XLIV. FIG. III.

The Rock Pipits are, I believe, confined entirely to the sea-coast, upon some parts of which they are very abundant. They make their nests upon the ground, or upon ledges of the rock bounding the sea-beach. I have frequently found them upon the Fern and Coquet Islands, and once met with one snugly sheltered in the centre of a heap of sea-weed which lay upon the sandy shore just above high-water mark. The nest is composed entirely of fine dry grass, and, although beautifully complete and symmetrical in its proper position, very soon falls to pieces if removed. The eggs are four or five, and occasionally six in number. I have seen no very striking varieties amongst them; they may be readily known from those of the other species of Anthus by their superior size; from some of the varieties of eggs of the skylark it would not be so easy to distinguish them; they are, however, usually broader, in comparison to their length, and are without the greenish colouring, which is frequently characteristic of the eggs of the skylark. The egg figured, sent me from the collection of Mr. Hancock, is more like the eggs of the skylark in shape and colour than is usually the case. 


\section{RICHARD'S PIPIT.}

Anthus Ricardi.

PLATE XLIV. FIG. IV.

THE eggs, from which I have selected one to form the subject of the accompanying drawing, were amongst those which the assiduous and successful bird-nesting rambles of the late Mr. Hoy added to our collections; they were brought by him from the Continent, and are in the collection of $\mathrm{Mr}$. H. Doubleday, of Epping, who has with his usual kindness sent me one to figure. The Messrs. Tuke have also received them from Germany.

This species, like the rest of the genus, makes its nest in a tuft of grass upon the ground. It is of dry grass, moss, and a few hairs; the eggs are four or five in number. 
INSESSORES.

CONIROSTRES.

\section{SKY-LARK.}

Alauda arvensis.

PLATE XLV. FIG. I.

THE eggs of the Sky-lark, though very rarely differing so much as to cause a difficulty in identifying the species, are nevertheless subject to much variety both in form and colour; some are large and oval; others are pyriform like those of the waders; some are of the deep sombre brown which marks the eggs of the titlark; others are tinted with green, and are, I think, the most characteristic of the species; whilst a few, and these are of rare occurrence, are so much less closely freckled, as to leave a light ground-colour. In a nest, which I found in Derbyshire some years ago, were two of these varieties; one of them resembled a good deal the eggs of the woodlark both in size and colour; the other was still lighter, the markings smaller, and not unlike eggs of the pied wagtail. These were in the same nest with three others of the usual size and colour. There is yet another variety which I had almost forgotten to mention, on which the chief part of the colouring is concentrated in a deep zone round the larger end, and in two or three specimens which I have seen the same deeper colouring was centred in a fingerlike mark on one side only. Like the eggs of many of our smaller birds, they are occasionally white.

The nest of this species is made almost entirely of dried grasses, finer towards the interior, mixed with a few roots; 


\section{XIV}
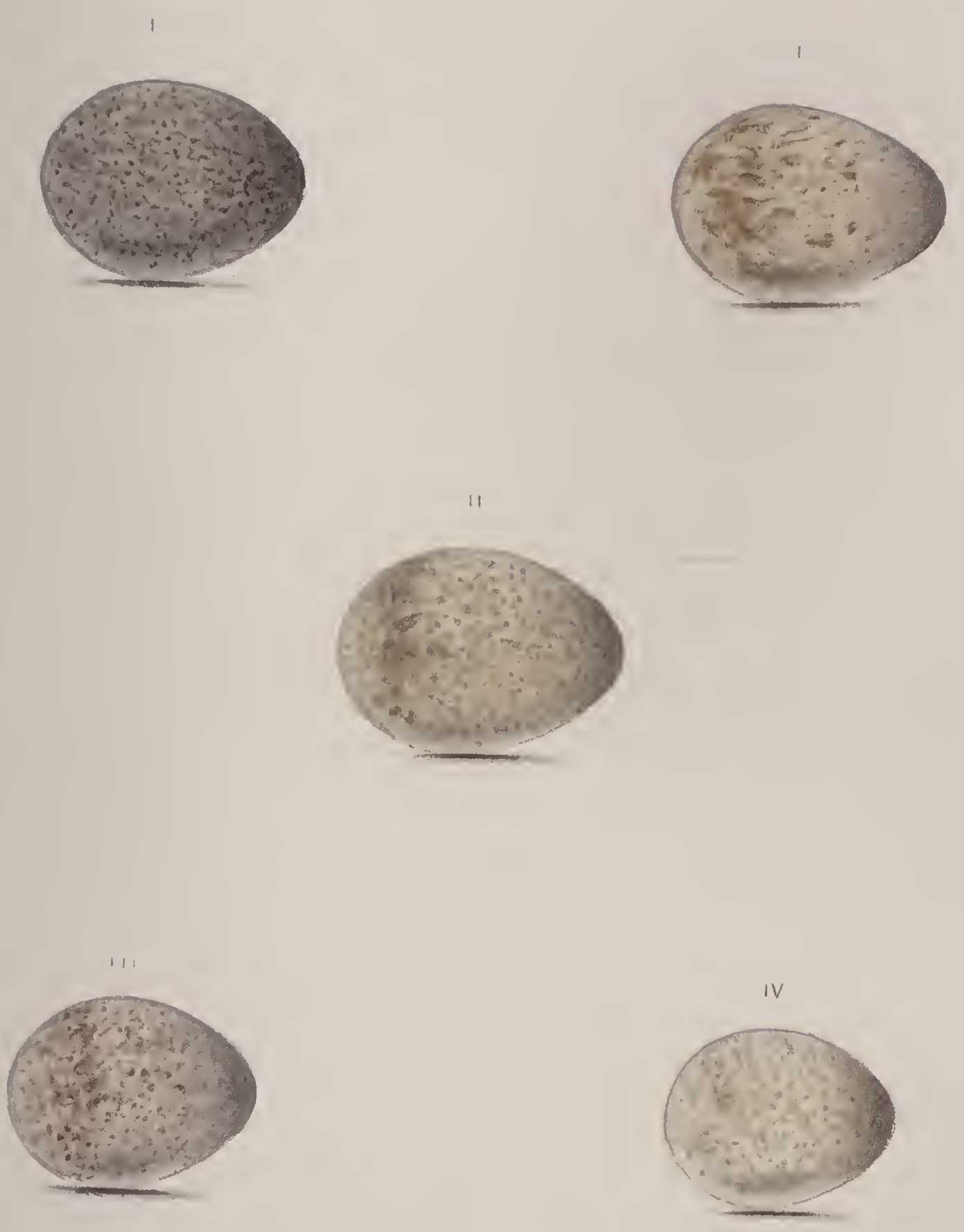

it is placed upon the ground, and may be found in almost every situation which the country affords; the grassy meadow, the corn-field, the open pasture, and on the bare sod of the ploughed land; it may also be met with amongst the long tufts of grass which abound in lands partially boggy, and sometimes in newly made plantations.

$\mathrm{Mr}$. Blyth mentions a remarkable instance in which the Sky-lark-its nest being laid open by the scytheconstructed over it a canopy of dry grass, to afford it the protection and concealment which the long grass, amongst which it was snugly sheltered, had previously afforded, an instance curious, because the same birds had probably the preceding year built their nest in a situation quite as much exposed to the daylight and the weather as the present one when left bare by the mowers.

The Sky-lark breeds earlier, but I have usually found its eggs in May and June; they are from three to five; frequently not more than three in number. 
INSESSORES.

ALAUDID $E$.

CONIROSTRES.

\section{CRESTED LARK}

Alauda cristata.

PLATE SLV. FIG. II.

Since the two instances of the occurrence of this species in the British Islands mentioned by Mr. Yarrell, others have been killed in Cornwall, and are recorded in the "Zoologist." The Crested Lark, which is met with on many parts of the continent, and is abundant on the opposite coast of France, breeds, like the sky-lark, upon the ground, and lays four or five eggs, which are scarcely to be distinguished from those of our well-known species. Specimens with which I have been favoured from the collections of Mr. Walter, Mr. Bond, and Mr. Newton, are somewhat larger than the usual eggs of the sky-lark, but do not differ from large eggs of that species; those forwarded to me by Mr. Newton, together with the nest in which they were taken, were sent to him from Holland.

The nest is much more compact than that of the skylark, and may be removed without difficulty. With the exception of two or three small bits of moss, it is built entirely of grass; and whilst the outside is composed of the stalks, the inside is lined with the soft flowering tops without their seed. 

X L V *
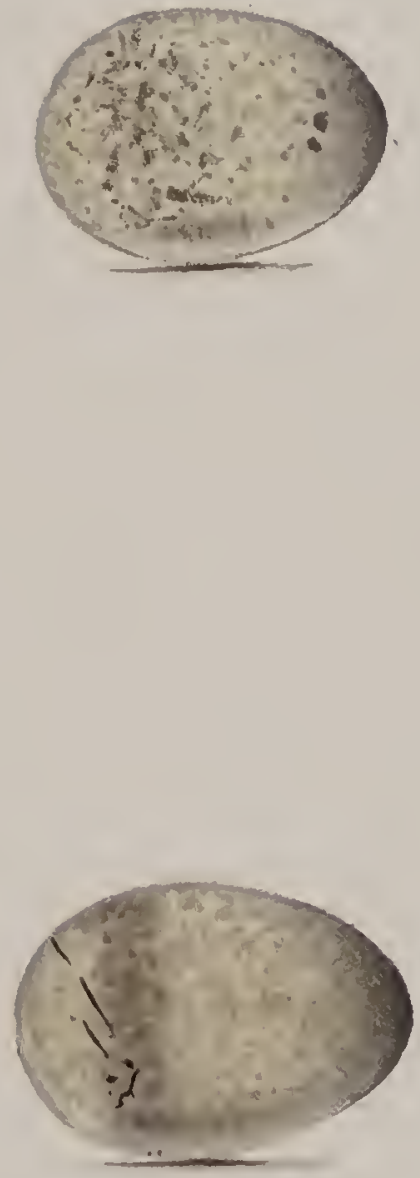
INSESSORES.

ALAUDID $A$.

CONIROSTRES.

\section{SHORE LARK.}

Alauda alpestris.

PLATE XLY.*

Mr. Wolley, who has given me the pleasure of figuring so many rare eggs, has accompanied those of this species with the following information. "I found the Shore Lark very common in East Finmark on all the cultivated lands near the sea, and also up the hills, although less numerous. It 'was very delightful to hear it singing as it sat on a post, or on a rail, or a barn top. At one house where I was staying, it used to come on the roof soon after midnight, and sing for several hours in the cool sunshine. Its nests, of which I found several, were placed like common larks, in a depression of the ground, often near a stone, and there was nothing very striking in the nesting habits or actions of the bird. One, whose nest I had some difficulty in finding, betrayed it by running on to its eggs whilst I was watching it at a few feet distance. The nests, when taken out of their place, are found to be of a loose structure, and are generally lined with down from the willow or other plants. The number of eggs commonly four, or sometimes five. The bird appears to be double-brooded, the first eggs being very early, the second laid in July. I found from experience, that if its nest and eggs are taken 
it will have a new nest and eggs twice again, at least, and not far from the original spot. It breeds on the high lands in the north of Lapland, quite in the interior of the country. In the autumn flocks of it are to be seen in the corn-fields like common larks in other countries on their way south along the course of the rivers."

Audubon found the Shore Lark breeding " on the high and desolate tracts in the vicinity of the sea " building its nest upon patches of lichen with which the stony surface is decorated, which he describes as beautifully varied, green and pure white, and every tint of colour.

Of the eggs figured, whilst one has the character of those of the wood lark, the other has quite the appearance of eggs of the sky lark, one of them is crossed by a black line like the eggs of the reed fauvette, a peculiarity which I have not before noticed in eggs of this genus. 
INSESSORES.

CONIROSTRES.

ALAUDIDE.

\section{WOODLARK.}

\section{A.LAUDA ARBOREA.}

PLATE KISV. FIG. III.

Great progress has been made of late towards a knowledge of the eggs of our British Birds. Till within a few year's the eggrs of the Woodlark were very little known, and were misrepresented in most collections by one of the varieties of those of the tree-pipit.

The difficulty in procuring its eggs may be accounted for by the value that is set upon the young birds, and the eagerness with which they are sought, to rear them for the cage.

The Woodlark, though not a rare bird, being met with in most of the southern counties, is yet nowhere numerous: north of York it is but seldom met with, but has been frequently taken by the bird-catchers in the neighbourhood of that city. It is partial to newly-inclosed lands, and to light heathy districts; and makes its nest for the most part on those bare pastures which generally surround them, especially if trees and plantations are not far distant; it may be found also on the bare fallow field.

The nest, which is composed of coarse grass and roots, mixed occasionally with moss, and the skeletons of decayed leaves, and lined with the same materials of a finer texture, together with a few hairs, is placed in a tuft of grass upon the ground. Mr. Neville Wood mentions 
having found one upon the stump of a felled tree. Mr. Hoy informed me that he has found the eggs early in March in mild seasons, and as late as the end of July; they are four or five in number, and are readily known from those of the sky-lark and the pipits, by their lighter ground-colour; they are not subject to much variety, but are sometimes marked with blotches of vinous colouring. When fresh and unblown they are of a beautiful rose colour.

Mr. Newton tells me, that the Woodlark is not uncommon in his neighbourhood, near Thetford, but that it is very local. "That the localities to which the birds are most partial are old sheep-walks in the vicinity of Scotch fir-trees. On places such as these the herbage is so scanty, that they can hardly be said to choose a tuft of grass as the situation of their nests, though they generally select a spot where the bents are the thickest; I have, however, found a nest where the turf was as short as a well kept lawn, and I have seen one secluded in a clump of heather. Their nests are usually more compact than those of the sky-lark, and will bear being taken up from the hole in which they are built."

The Woodlark breeds annually in Oatlands Park, where heath and fir-trees are abundant. In the Spring of 1849, on the 4th of April, Mr: J. Hancock found a nest and eggs within a few yards of my house. It was fortunately well sheltered in a thick tuft of rough dry grass, and some days after, when the old bird was sitting very close, it was completely covered for some hours by a heavy storm of snow. The note of the Woodlark, one of the earliest of the year, has a peculiar charm,- - a wild cadence, which, to my ear, is not surpassed by any bird of summer. 
INSESSORES.

CONIROSTRES.

\section{SHORT-TOED LARK.}

\section{ALALTA BRACHYDACTYLA.}

PLATE XLY, FIG. IY.

SINCE the Short-toed Lark has made its appearance in this country, and been admitted to a place amongst our British Birds, I am glad to avail myself of the kindness of Mr. Walter, which enables me to figure an egg of this species from his collection. This egg, it will be seen, closely resembles those of the woodlark, and is rather more rufous in its colouring than the egg which was figured in the former edition from the collection of $\mathrm{Mr}$. Gould.

The Short-toed Lark is met with in abundance in various parts of the South of Europe.

Whilst wandering during the autumn upon the grassy slopes of the Appenines, which form a back ground to the city of Genoa, I frequently heard the song of a Lark, the notes of which exceeded in power and sweetness those of any other bird it has been my pleasure to listen to ; and I have no doubt that the bird of which I speak was the Short-toed Lark, from its similarity in size. I have watched them while singing, and hovering, like the sky-lark, high in the air, and almost beyond my view, and at the time a strong wind was blowing, and have wondered that. I could distinctly hear every note they uttered. 


\section{LAPLAND BUNTING.}

\section{Plectrophanes Lapponica.}

PLATE XIVI., FIGS. I. AND II.

The only account which we have of this species during the breeding season, is that of Sir John Richardson, which I copy from his "Fauna Boreali Americana":"In the year 1827, it appeared on the plains at Carlton House, about the middle of May, in very large flocks. During their stay of ten or twelve days, they frequented open spots, where recent fires had destroyed the grass. They came to Cumberland House a few days later in the season, and there kept constantly in the furrows of a newly ploughed field. In the preceding year they were seen, though in smaller flocks, in the vicinity of Fort Franklin, in the beginning of May.

"They breed in moist meadows on the shores of the Arctic Sea. The nest, placed on a small hillock among moss and stones, is composed externally of the dry stems of grass interwoven to a considerable thickness, and lined very neatly and compactly with deer's hair. The eggs, usually seven, are pale ochre yellow, spotted with brown."

Those which I have figured are from the collection of Mr. J. Hancock, and were selected from a large series received by him from Greenland. At first sight they have little resemblance to those of the buntings; but, on 

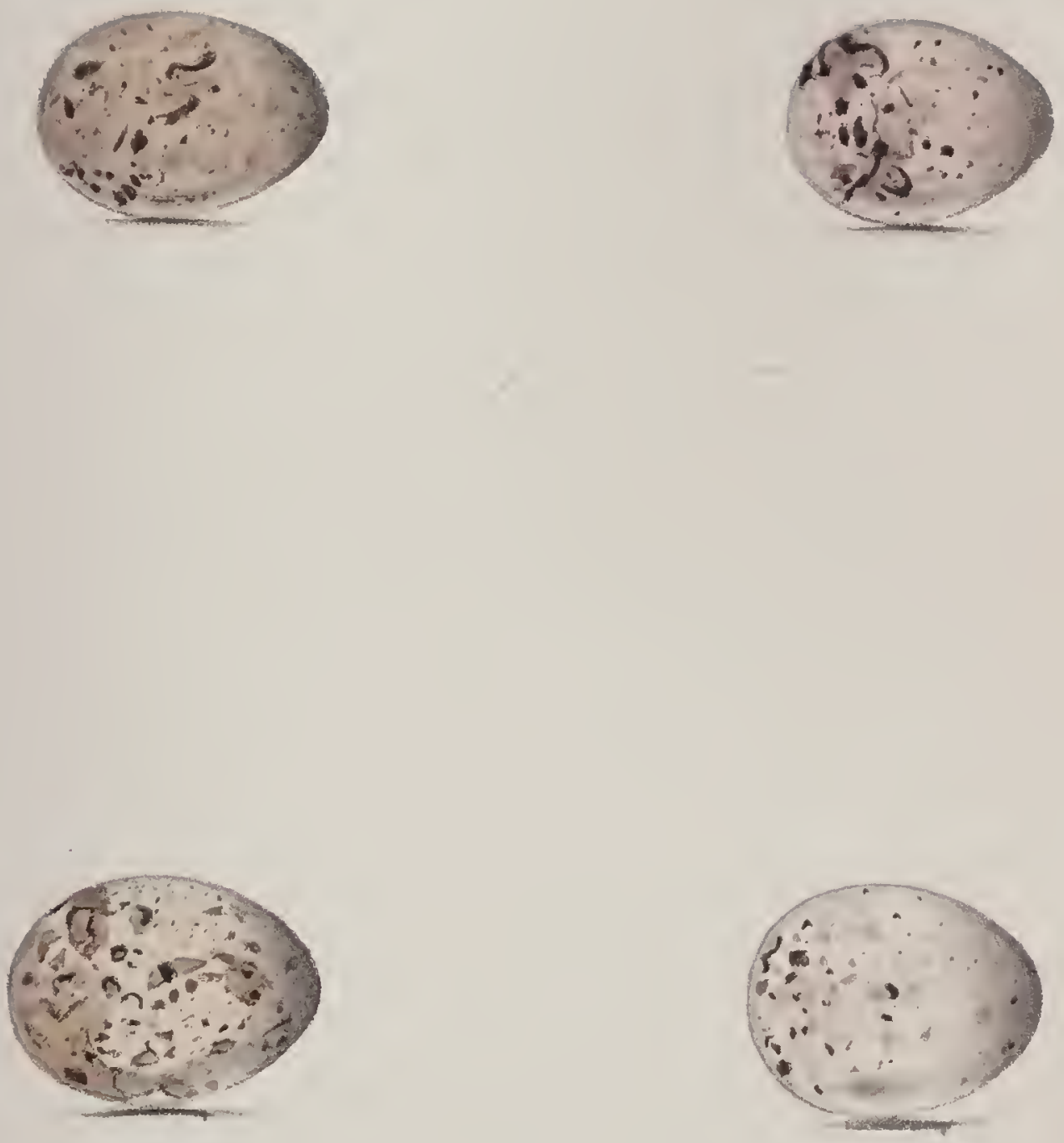

closer examination, some of the well-known map-like marks, so characteristic of that genus, are there; in other respects, they shew their relationship to the larks, and that they are well placed between the two genera.

A nest from Labrador, sent me by Mr. Newton, is formed entirely of the finest grasses, interwoven toward the inside with numerous duck's feather's. 
INSESSORES.

EMBERIZIDA.

CONIROSTRES.

SNOW BUNTING.

TAWNY BUNTING, SNOW FLAKE.

Plectrophanes Nivalis.

PLATE XLVI., FIG. III.

The Snow Bunting has never been known to breed in this country, but only visits us during the winter months, and returns to more northerly regions to propagate its species. Pennant says that they breed in Greenland. Mr. Hancock, of Newcastle, has the eggs from Davis's Straits ; and Mr. Froctor, of Durham, found the nests of this species when in Iceland, in the month of June; they were placed amongst large stones, or in the fissures of rocks, and were composed of dry grass, lined with hair or feathers.

Sir Joln Richardson says that they breed on the northermmost of the American islands, and on all the shores of the continent, from Chesterfield inlet to Behring's Straits. Captain Lyons found their nests on Melville and South.ampton islands, "in the crevices of rocks, or amongst loose stones, and constructed of dried grass, neatly lined with white deer's hair." He mentions having met with one which was placed in the dead body of an Esquimaux child. Lieutenant Ross also describes one which was found at the Whale-fish Islands, early in July, formed of dry grass, and lined with feathers, which were covered with a fine white down. 
When in Norway we saw the Snow Buntings in their beautiful summer-plumage of black and white, and succeeded in finding a single nest and young ones under some loose stones upon one of the larger islands.

It will be seen from the various accounts of this species which I have quoted, that it varies the lining of its nest considerably, according to circumstances, soft materials of any kind being difficult to procure in those sterile, thinly peopled countries.

The egrss are from four to six in number, and are subject to great variety; some are like those of the tribe of birds to which it belongs, whilst others are exactly like those of the green-linnet. Mr. Hancock, of Newcastle, has a variety thickly marked all over with spots of a reddish and purple hue, and much resembling eggs of the spotted flycatcher.

The variety of the egg figured, which is, I think, the most common, is from the collection of Mr. Salmon.

Mr. Wolley has met with this species during the breeding season on several of the highlands of Feroe; and from Finland where he now is, waiting the breeding season, he has sent me the following notes: "In these dreary spots a simple echo-less song draws one's attention to the handsome cock bird. He sits upon a fragment of rock, cheering his sombre-coloured mate, who is brooding over her treasure in some sunless hole not far off. In some place, where the ground is covered with rough stones, he has found a dry recess, in which, with his partner's help, he has built a compact nest of the finest grass stalks, and lined it with feathers. In such an artificial cradle as I have just suggested, I left five young snowfinches upon a mountain in Finland. It was on the 22nd of June, and they were, apparently, about a week old." 
INSESSORES.

EMBERIZIDA.

CONIROSTRES.

\section{COMMON BUNTING.}

CORN-BUNTING, BUNTING-LARK.

\section{Emberiza mitaria.}

PLATE XLVIY. HIH. III.

The Common Bunting, perhaps better known by the name of Corn-bunting, or Bunting-lark, builds its loosely constructed nest on or near the ground, sometimes in briers, more commonly in a clump of grass, and occasionally at the root of a low shrub; it is usually in the open fields, and at a distance from the hedge-rows; it is composed of a few sticks, pieces of moss, and dry grass, becoming finer towards the inside, which is sometimes completed by the addition of a few hairs. The eggs are four or five in number, and differ a good deal in size, shape, and colour, but always retain the character of the genus. Their size prevents them from being mistaken for those of any other bunting. The egg figured is larger and more richly coloured than usual. 

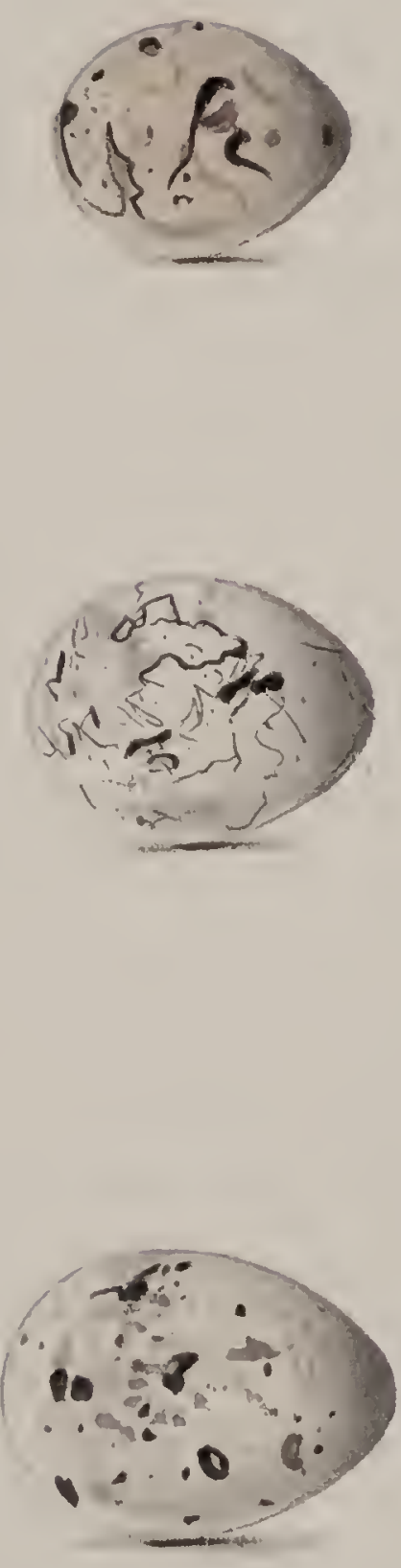
INSESSORES.

CONIROSTRES.

EMBERIZIDA.

\section{BLACK-HEADED BUNTING.}

REED-SPARROW, BLACK-CAP.

\section{EMBERIZA SCHGNICLUS.}

PLATE XLVII. FIG, I.

DIFFERENT opinions have been held with regard to the position of the nest of this species. Some authors, in describing the situation of its nest, have no doubt confounded it with that of the sedge-warbler, as noticed by Mr. Selby and the Rev. L. Jenyns.

It usually builds its nest in a clump of grass, or low bush, preferring a marshy situation. I have, however, though rarely, found the nest at an elevation of two feet or more above the water, and supported by a bunch of the common reed, not fixed like the nest of the reedwarbler attached to the perpendicular stems, but supported upon a bunch of them which had been prostrated by the wind.

The nest is composed of the stalks of various plants, some moss, and is lined with hair. The eggs are four or five in number, varying only in the browner or more purple tint of the general colour. They have much resemblance in their marking to the eggs of the chaffinch, but are always much darker. 
INSESSORES.

CONIROSTRES.

\title{
YELLOW BUNTING.
}

\author{
YELLOW-AMMER, YELLOW-YOWLEY, on GOLD SPINK.
}

\author{
EMBERIZA CITRINELLA.
}

PLATE XLVII, FIG. II.

The Yellow Bunting is one of our most common birds, and its singularly marked eggs always form a large portion of the bird-nesting spoils which fill the string of the school-boy. Although subject to great variety, they are usually so characteristic of the species that it would not be easy to confound them with those of any other bird, except the rarer eggs of the cirl bunting. In form they are occasionally very long and oval, sometimes round as a marble. I have seen a single specimen of this egg so much suffused with colour that it might have been mistaken for that of the cuckoo.

The nest is formed outwardly of straws, bits of moss, sticks sometimes, and coarse grass, finer towards the inside, which is finished with roots and a few hair's. It may be found upon almost every briery hedge-dyke; it is most commonly placed upon the ground, but not unfrequently occupies the centre of a thick bush.

Mr. Salmon has found the nest at the unusual height of seven feet above the ground, amongst the thick bushy branches of some broom; and once, very much to my surprise, whilst seeking for nests of blackbirds and thrushes, amongst the firs of a young plantation, I dis- 
covered a nest of this species about six feet above the ground, upon the branch of a spruce fir-tree, exemplifying a remark made to me by Mr. Yarrell, that as the buntings become more nearly allied to the larks by the greater length of their hind claws, so they likewise resemble them in their habit of building upon the ground. Of this the common and snow buntings, both of which have the claw produced, are instances; the former very rarely, the latter, as far as known, never raising its nest above the ground.

The eggs of the Yellow Bunting are from three to five in number ; the female sits very closely, and is not easily driven from them. 
INSESSORES.

EAIBERIZIDAE.

CONIROSTRES.

\section{CIRI BUNTING.}

\section{EIIBERIZA CIRLUS.}

PLATE XLVIII., FIG. II.

The Cirl Bunting, together with its nest and eggis, was first discovered in this country by Colonel Montague, and as I have never seen the nest, I quote his information. He says, "We first discovered this species near Kingsbridge, in 1800; they are indigenous to Devonshire, but seem to be confined to the southern parts of that county contiguous to the coast, having found them extending as far as Teignmouth, at both of which places we found their nests, but have never observed them far inland. It generally builds in furze, or some low bush; the nest is composed of dry stalks, roots, and a little moss, lined with long hairs and fibrous roots; the eggs are four or five in number."

The Cirl Bunting breeds also in Cornwall, from which county the Messrs. Tuke have received their eggs.

This species is not uncommon in the neighbourhood of Bath and Bristol during the winter months. 

XLVIII.
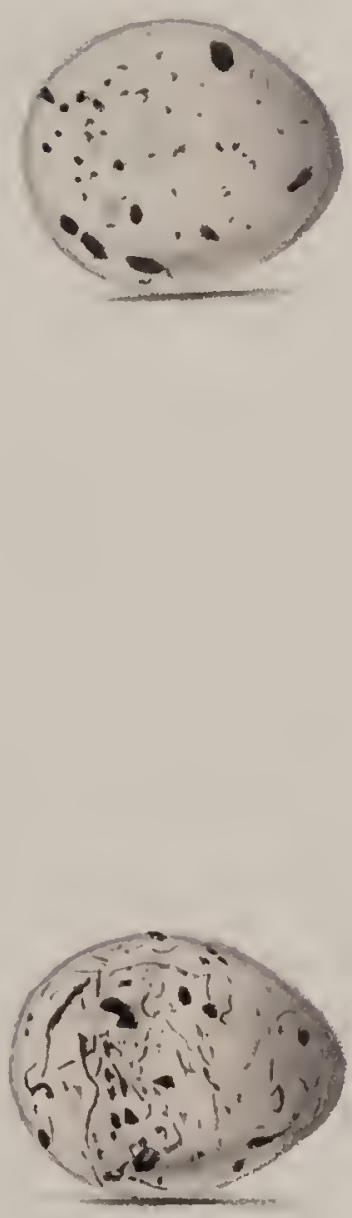
CONIROSTRES.

\section{ORTOLAN BUNTING.}

\section{EMBERIZA HORTULANA.}

PLATE XLVIII, FIG. I.

In Italy, Germany, and various part of the Continent, the Ortolan Bunting is an abundant species. I am fortunate in being able to give some account of it, from an eye witness of its habits. The liberality of the late Mr. Hoy supplied me with the nests and several beautiful varieties of the eggs of this species, together with the following information:- "The Ortolan Bunting begins to build early in May; it places its nest almost invariably in the corn, preferring rye to other kinds; indeed it is partial to light sandy soils where rye is much cultivated. The nest is placed in some little hollow in the ground, in the manner of that of the sky-lark. It is formed of dry grass and roots, thickly lined towards the interior with very fine roots; in some, the inside is furnished with a few hairs. The eggs are four or five, sometimes, though rarely, six in number. I have never found them breeding except amongst corn. The male is almost incessant in its monotonous song during the pairing-season; it much resembles others of the tribe, having some resemblance to that of the cirl, as well as the reed bunting."

Some of the varieties of the eggs are a good deal like those of the reed bunting, and others bear some likeness to those of the yellow bunting, but are usually easily known from both by the number of round spots with which they are marked. 
INSESSORES.

FRINGILLID AS.

CONIROSTRES.

\section{CHAFFINCH.}

SKELLY, SHELL-APPLE, PICK-A-TREE.

\section{FringILLA COELEBS.}

PLATE XLIX. FIG. I.

Few can have passed through life so unobservant as not to have seen, and in seeing to have admired, the nest of the Chaffinch. No one whose heart is touched by the beauties of Nature, can have examined this exquisite structure without ultering some exclamation of wonder and delight, and of comparing it, like the poet, with all that is most admirable in art and of man's invention.

Amongst even the tiny architects of the feathered race there are few that can compete with the Chaffinch. Its nest is not only perfect in its inward arrangements, but is tastefully ornamented on the outside as well, with materials such as nature can alone supply. In its outward decoration some individuals employ much more of taste than others, but all seem to think it indispensable to deck the green walls of their dwellings with gems of white; and when, in the neighbourhood of our towns, the beautiful white lichens which are used for that purpose are obscured and blackened by the smoke of our chimneys, they have recourse to something else.

A nest of the Chaffinch, which was built in an old willow-tree in my father's garden, amidst the smoke of Newcastle, where no white lichens could be found, was 
XIJIX.

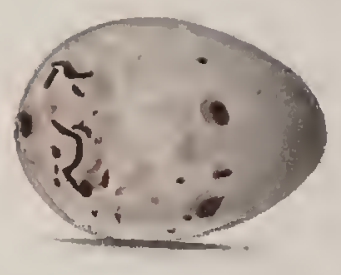

3

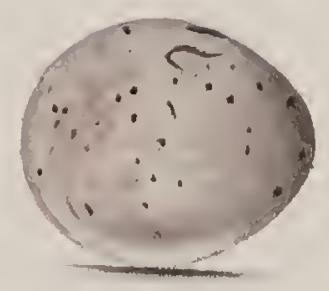



stuck over outside with small bits of white paper. Mr. Rennie says that, in the neighbourhood of the cotton factories at Catrine, in Ayrshire, he has seen many Chaffinches' nests thus decked with small tufts of cotton wool.

The Chaffinch builds its nest in many different situations, preferring old moss-grown apple- or crab-trees, and white thorn bushes. There is, however, scarcely a low tree upon the branches of which the nest may not be sometimes found, occasionally upon the flat bough of a spruce-fir, in hollies, laurels, and furze-bushes, and often in hedges. I have found one on the top of a dead stake fence. The nest is small in comparison with that of most other birds, being usually only an inch and three-fourths in diameter inside; it is composed chiefly of moss, so worked and matted together with wool, that it is no easy matter to pull it into pieces as small as those of which it was first formed; inside of this is a very thick lining of dry grass, wool, feathers, thistle-down, and hair, in succession.

The eggs are four or five in number, and rarely differ much from the accompanying figure. I have taken some of a light blue, blotched with reddish colouring, and much like those of the bullfinch. 
INSESSORES.

FRINGILLIDR.

CONIROSTRES.

\section{MOUNTAIN FINCH.}

BRAMBLING.

Fringilla montifringilla.

PLATE XIIX, FIGS. II. AND III.

To the kindness of Mr. Dashwood I am indebted for the pleasure it affords me to figure an egg, about which nothing has, with any certainty, been before known; the eggs have been described as resembling those of the green-linnet, but are, as might be expected, very much like those of the chaffinch.

Mr. Dashwood has had the Brambling for some years at his residence at Beccles, Suffolk, and from him I have the following interesting notes. His aviary is a large one, inclosing a considerable piece of ground, surrounded by ivy, and planted inside with shrubs, so that the birds enjoy something of their native liberty.

The nest having been completed four days, the female laid her first egg on the 16th of June, 1839, depositing another daily till the 21 st, when they were removed.

"The nest was deep, the walls thick, a large quantity of materials employed for the foundation, which was worked among the stalks of the ivy leaves. It was composed of moss, wool, and dry grass, and lined with hair. Portions of the nests of the chaffinch, green linnet, whitethroat, and yellow-bunting, were plentifully supplied, so that ample choice of materials was afforded.

"In the latter part of July of the same year, another pair of Bramblings built, placing their nest on the ground 
close to a shrub on a tuft of grass. Outside of the nest of moss, lined with hair. From this nest I removed four eggs on the 1st of August. On the 17th of June, 1840, they laid again, having built in the ivy. This nest I did not disturb, and although the eggs were hatched, they did not succeed in rearing the young ones."

Soon after these notes were sent to me, Mr. Dashwood ceased to keep these birds in confinement; he has, however, supplied me very liberally with two other examples of the egg to figure.

In a state of nature the Brambling would not have built its nest upon the ground.

Mr. Wolley, who states that the Brambling breeds plentifully near Muonioniska although he arrived there last summer too late to obtain the eggs, has sent me the following descriptions of three nests which he saw in the museum at Stockholm.

One, which was like the nest of the chaffinch and contained five eggs also like the eggs of the chaffinch, was built principally of lichens and fine grass, with a few feather's inside, A second, "taken on the 13th of June, is made chiefly of the black, hair-.like, lichen which hangs from the fir-trees in these far northern regions. The third nest was found on the 8th of June, and is made of hair, feathers, grass, and moss, and has a good many feathers in the lining; it contains six eggs."

Whilst on our way towards the north, June 8th, we saw some of the Bramblings in the pine forests of Norway, but searched till we were weary for their nests to no purpose. On our return homewards through the same district, July 1st, we had, however, the mortification of knowing that the nests must have been there, for the birds which we had seen before were now accompanied by their young ones. 
CONIROSTRES.

\section{GOLDFINCH.}

\section{Fringilla carduelis.}

PLATE L. FIG. I.

I HAVE nowhere seen the Goldfinch so abundant during the breeding-season as it is in the midland counties of Derby, Nottingham, and Leicester, where it is universally known by the absurd name of proud tailor. Most of the gardens and orchards which surround the various villages and farm-houses are their resort during the summer months. The favourite position for their nest in such situations is similar to that chosen by the chaffinch, the bough of an apple- or pear-tree; and when in the neighbouring fields, that of a low elm. It is also frequently built in evergreens. I remember finding a singularly beautiful nest of this species at the top of a lofty laurel, which, surrounded as it was by the green leaves, very much resembled some of those diminutive nests of the hummingbird, which are frequently brought to this country encircled by evergreen leaves; this bush had been the constant resort of the birds, during the cold and protracted spring, for several weeks previous to the discovery of the nest, so that they seem to have made their choice of its site on their first arrival in the neighbourhood.

The nest is very small, and is sometimes a good deal like that of the chaffinch in neatness of outline, although 
I.

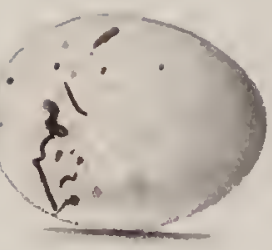

(2. 

without its compactness of form; it contains also a much greater proportion of moss in its construction. The outer part is of moss and roots, closely intermixed and twisted together with wool, and ornamented outside with lichens; it is thickly lined with the soft seed of willows and thistles, mixed with the down of feathers, and a few hairs. The eggs are four or five, and rarely six, in number; they vary little, and greatly resemble those of the grey and mountain linnets 
INSESSORES.

FRINGILLIDA.

CONTROSTRES.

\author{
SISKIN. \\ Fringilla spinus
}

PLATE L. FIG. II.

Several instances of the Siskin's breeding in this country are recorded by Mr. Yarrell. From the information of Mr. Meyer, he says that it has twice built in furze, about three feet from the ground, near Coombe Wood, the eggs being taken in both instances and hatched under canaries. It is more frequent in Scotland than in England, for Sir W. Jardine says, that they have bred in a large fir wood at Killin, and also in a wood near New Abbey, in Galloway. Mr. Yarrell says, that Mr. Drew has met with them during the breeding-season on the borders of Loch Fine, and that Mr. Gardiner, of Dundee, has known of a nest and young ones in Camperdown woods, which was built close to the trunk at the insertion of a branch of a spruce-fir, about six feet from the ground; it was composed of materials similar to those used by the chaffinch.

For the egg from which my former drawing was made, I was indebted to the late Miss Fisher; it was laid, together with three others, by a bird which she had three years in confinement.

For the egg now figured, I have to thank Mr. John Hancock, who has also kindly sent me the following 
information :- " When on a visit in 1850 to Mr. St. John, at Elgin, he drew my attention to the locality where he suspected that the Siskin was building, and, after much searching, we succeeded in obtaining the object of our desire. The first nest was found near Inverness, by $\mathrm{Mr}$. Lewis Dunbar, on the 10th of April. It had four eggs, and was placed near the end of a branch of the spruce-fir. A few days afterwards (May 2nd), I took, near Elgin, other two nests, which are the only ones I have had an opportunity of seeing in their natural position; they contained young; one had five, the other four, and a rotten egg; they were both built near the extremity of branches of the spruce-fir. The foliage of the trees was very dense, so that the nest could scarcely be seen. Last year I received another nest, containing five eggs, from Ross-shire. The nest is small, measuring in diameter outside, three inches; inside, one inch and three quarters; depth of cavity, one inch and a quarter. It is compused outside of moss, twigs of the fir, and delicate vegetable fibres, lined with a few hairs and a little down. There is also generally a feather or two, and occasionally a little wool." 
INSESSORES.

CONTROSTRES.

\section{COMMON LINNET.}

GREY-LINNET, BROWN-LINNET.

Fringilla cannabina.

PLATE LI. FIG. I.

IT was long supposed that there were two species under the common name of grey-linnet. We always believed so when at school, for those nests which we used to find in hedges were, for the most part, considerably larger than those built in furze-bushes; there was, too, a great disparity in the size of the eggs, some being so large that when mixed with small specimens of the eggs of the green-linnet, we had difficulty in setting apart those of each species.

In districts where furze abounds it is the favourite nesting resort of the grey-linnet. I have, however, found quite as many of their nests in the hedges of an inclosed country. Mr. Yarrell mentions a nest of this species which was found in a fir-tree ten or eleven feet above the ground.

The nest differs little from that of the green-linnet, except in its having generally a larger proportion of roots, and less of moss in its composition. It is formed of small sticks, stalks of plants mixed with moss, roots, and wool, and is lined with hair and feathers, with sometimes a mixture of thistle or willow down. The eggs are four or five, and not unfrequently six, in number; they differ considerably. The third figure of the plate is as good a representative of some of them, as it is of the egg of the mountain-linnet. 

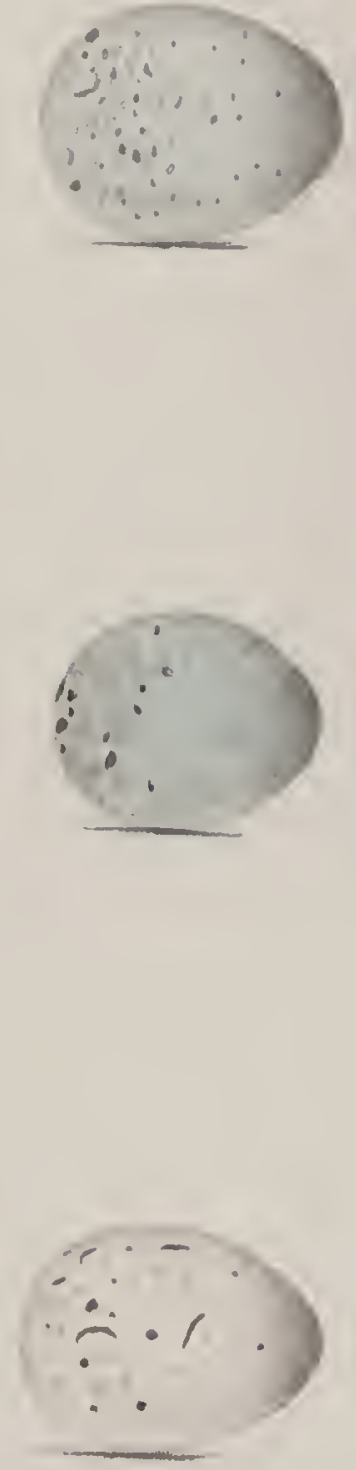

INSESSORES.

CONIROSTRES.

FRINGILLIDAB.

\section{LESSER REDPOLE.}

\section{Fringilla linaria.}

PLATE LI. FIG. II.

Mr. YarRell mentions Halifax as the southern limit of the Lesser Redpole in this country during the breedingseason. It would appear, however, that it is distributed pretty generally through the midland counties. Mr. Wolley, who lives at Beeston, near Nottingham, informs me that it breeds in his neighbourhood, and that his brother has found its nest near Rugby, in Warwickshire. Mr. Briggs meets with it near Melbourne, in Derbyshire. Mr. Dashwood has found several nests near Beccles, in Suffolk. In the position of its nest this species differs from those allied to it. It is usually placed, like that of the chaffinch, upon the bough of a low tree or single thorn, a hazel-bush bordering the outskirts of mountain woods, sometimes in alders by the margin of a stream, and occasionally upon the branches of a crab-tree, when forming part of a high hedge. Mr. A. Newton tells me that it breeds yearly near Thetford, building its nest, close to the trunk of the tree, in plantations of young larch firs of no great height; but that he once found $a$. nest at least sixty feet from the ground, and this was placed near the outer end of a branch. It is very small, and of the most elegant construction, and is formed of the stalks of plants, roots, moss, and dry grass, with hair towards the inside, and is thickly and most beautifully lined 
with the catkins of the willow, equalling in whiteness and texture the finest cotton wool. I have found the nest without any of the last-mentioned material, hair, fine grasses, and feathers being substituted in its stead. The eggs are from four to six in number; the time of incubation about the middle of June. 

LI ${ }^{*}$

$\therefore$

$\infty$

m.

2 


\section{MEA L Y RED POLE.}

\section{Fringilla Canescens.}

PLATE LI.**

Although not myself a believer that the Mealy Redpole is specifically distinct from the lesser, I have figured the eggs in deference to the opinion of many who, with greater experience, think that it is. Taking a series of the eggs which have been sent me by Mr. Wolley, they are larger than those of the other species, more varied, and more closely spotted with rufous colour, still some specimens do not at all differ from them. Mr. Wolley says, "The Mealy Redpole most seasons is seen throughout the winter in Lapland, though the greater number go southwards. Even in the breeding time it seems to be a gregarious bird, for a considerable number of nests are to be found in a small space of the birch forest, and the region of birch trees seems to be its proper habitat. In 1854 , I principally met with it in a small district at a great elevation towards the Norwegian frontier. In 1855, when all soft-billed birds were so scarce after the preceding severe winter in the south, the Mealy Redpoles were abundant everywhere, from the very strands of the arctic ocean, over the mountains, where the nests were often close to the ground (as, indeed, they are sometimes in other situations) to the extensive forests of Muonioniska. 


\section{FRINGILLIDAE.}

"The eggrs are very variable in size, shape, and marking, generally less than eggs from Greenland, where the bird, whether it be considered distinct or not, appears to be of a larger size; but it is remarkable how precisely nests from such distant parts of the world resemble each other in materials and structure; not a twig or filament in the pretty nests from Greenland but what is repeated in the equally pretty Lapland nests.

"The time for laying seems very variable. In one wood eggs and young birds are to be found in every stage of advance before there could have been time for any to belong to a second brood." 
INSESSORES.

CONIROSTRES.

FRINGILLID E.

\section{MOUNTAIN LINNET.}

TWITE.

FiRINGILLA MONTIUM.

PLATE LI. FIG. III.

The Mountain Linnet, like the lesser redpole, is chiefly confined to the northern portion of this country during the breeding-season. It may then be met with in the wilder districts of the northern counties of England, and in various parts of Scotland. Mr. Salmon found two of their nests in the Orkney Islands: one of these was placed amongst some furze, the other upon the ground amongst the young corn; a singular situation for the nest of a linnet. We found some of their nests upon the bare mountain sides of Shetland, built amongst the long heather. They were composed of heath and dry grass, lined with wool, fine roots, hair, and feathers, and contained four or five, and frequently six, eggs. 
INSESSORES.

FRINGILLIDE.

CONIROSTRES.

\section{GREEN LINNET.}

GREEN-FINCH, GREEN-GROSBECK.

CoccothraUstes CHLORIS.

PLATE LII. FIG. I.

THE nest of the Green Linnet is loosely put together on the outside, which is composed of twigs, roots, moss, and wool, becoming finer and more compact as the structure advances; it is thickly lined with wool, very fine roots and grass, hair, and a few feathers. It may be found in almost every high edge, in thorn-bushes, in hollies, and other evergreens, in ivy against trees and walls; and, in one instance, I have found it upon a pollard apple-tree. It is most commonly at an elevation of five or six feet or more, rarely lower. The eggs are four or five, and vary but slightly.

Birds in a state of nature rarely lay those mis-shapen lusus-like eggs which are common amongst our domestic poultry. I have one, however, from the nest of the Green Linnet, which is only half the usual size, and quite white, and have seen similar eggs from the nests of several other species. 
LII.
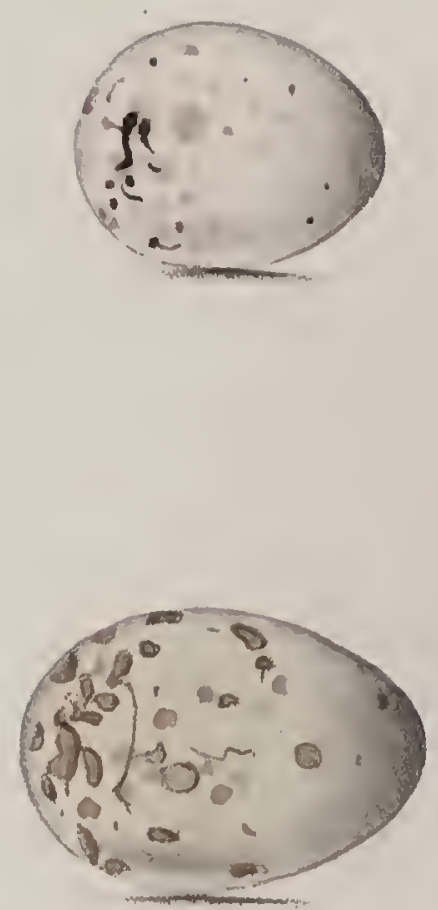

2. 

INSESSORES.

CONIROSTRES.

FRINGILLIDA.

\section{HAWFINCH.}

\section{Coccothraustes vULGaris.}

PLATE LII. FIGS. II, AND IIr.

Mr. Henry Doubleday, of Epping, had for some years suspected that the Hawfinch must breed in the neighbouring forest, having occasionally seen the birds, and also some eggs of a species then unknown to him; and to his assiduity, ornithologists are indebted for the knowledge that this species is indigenous in the country; to his liberality, I am indebted for the nest and eggs of this rare bird. The nest is remarkably shallow, and carelessly put together, being scarcely deeper than that of the ring-dove; in materials it resembles that of the bullfinch, without its nicety of form; it is chiefly of sticks, interspersed with pieces of white lichen, and is loosely lined with roots. Mr. Doubleday has himself favoured the public with his observations on the subject, and these I copy from the Magazine of Zoology and Botany: "Their extreme shyness has, no doubt, contributed to keep us in ignorance of their habits and economy; in this trait they exceed any land bird with which I am acquainted, and in open places it is almost impossible to approach them within gunshot. About the middle of April they pair, and in a week or two commence nidification. The situation of the nest is various, but it is most 
commonly placed in an old scrubby whitethorn bush, often in a very exposed situation; they also frequently build on the horizontal arms of large oaks, the heads of pollard hornbeams, in hollies, and occasionally in fir-trees in plantations; the elevation at which the nest is placed varying from five to twenty-five or thirty feet. The most correct description of the nest which I have seen is in Latham's Synopsis. It is there said to be composed of dead twigs of oak, honeysuckle, \&c., mixed with pieces of grey lichen; the quantity of this material varies much in different nests, but it is never absent; in some it is only very sparingly placed amongst the twigs, in other's the greater part of the nest is composed of it; the lining consists of fine roots and a little hair.

"The eggs vary in number from four to six."

Mr. Bond has kindly sent me the two beautiful varieties now figured, which were taken near Hampstead. 


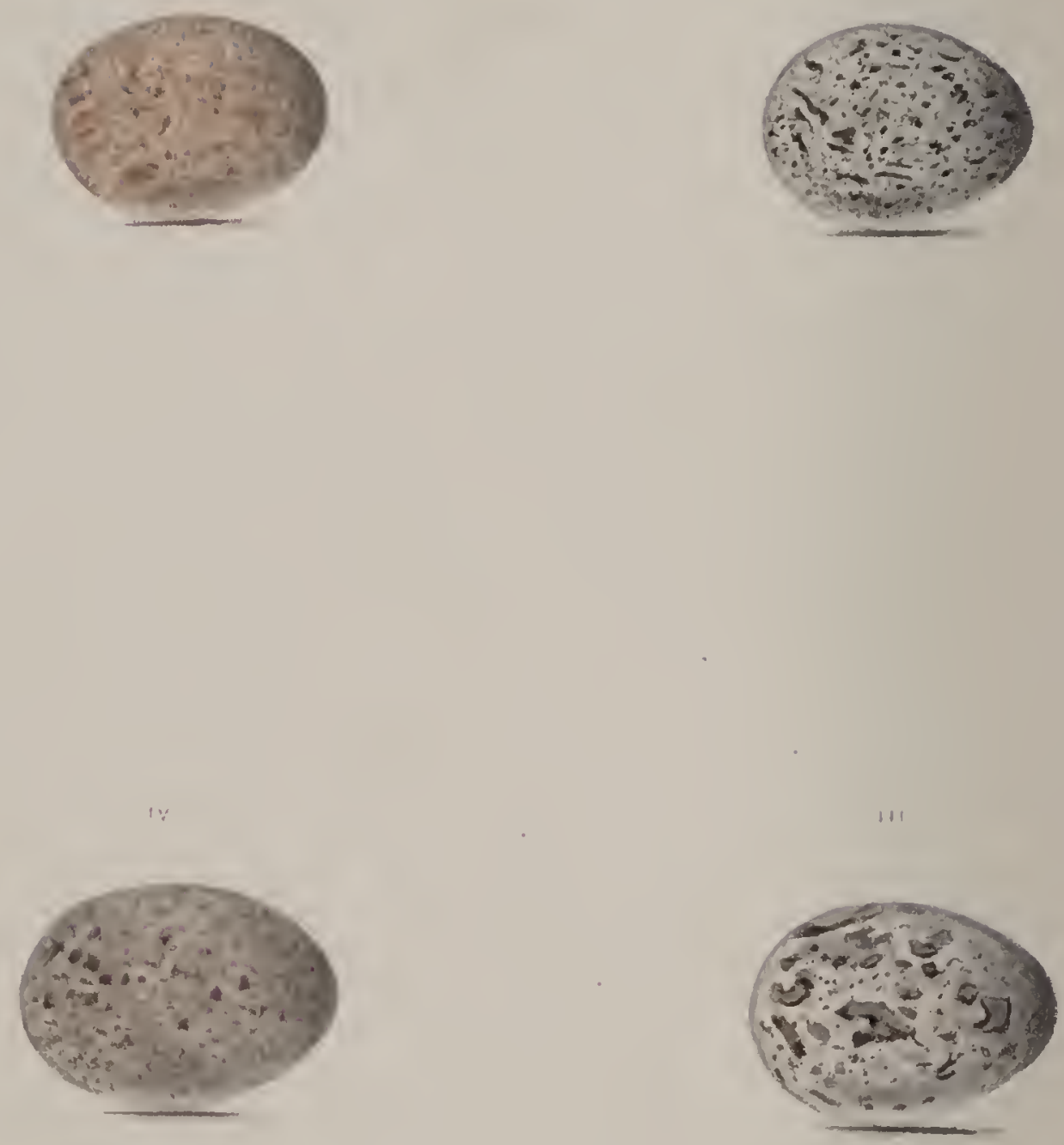
INSESSORES.

CONIROSTRES.

FRINGILLIDE.

\section{TREE SPARROW.}

\section{Passer montant's.}

PLATE LIII. FIGS. I, AND II.

The Tree Sparrow is by no means so rare a bird as it has been generally considered by ornithologists. It breeds abundantly in Yorkshire, Derbyshire, and Northumberland, and most probably throughout the northern counties.

Its habits are usually somewhat more retired than those of our common sparrow, choosing for its nest holes in trees, and not in the immediate neighbourhood of our dwellings. A number of nests, found by the Rev. W. D. Fox, in Derbyshire, from which he kindly sent me a series of varieties of the eggs, were built either in the holes of large trees, or those of pollard-willows.

When at Cullercoats, in Northumberland, Mr. John Hancock took me to an old wall surrounding the gardens of Whitley Hall, in which a number of the Tree and House-sparrows were breeding in common, without any distinction as to habit, locality, or nest.

Mr. Yarrell, quoting the information of the Rev. J. Dimock, says, "These birds frequently build in the thatch of a barn, in company with the House-sparrow, not, however, entering the thatch from the inside of the building like them, but by holes in the outside: five or six instances of this sort occurred in one building, and one or 
two pairs built upon the farm-house. They also built in the deserted nests of magpies and crows, in which they formed domed nests, as does the Common Sparrow, when it builds among the branches of trees."

From the same source I copy information supplied by the late Mr. Hoy, who says that, on the Continent, where this species is rather numerous, they often build their nests in holes in the tiling of houses, and in stacks of wood-faggots.

As I have mentioned above, the nest of the Tree Sparrow does not differ from that of the other species, being like it formed of dry grass abundantly lined with feathers.

The eggs are four or five in number; are less than those of the House Sparrow, and are usually more oval in form, and wider in proportion to their length; they are commonly more closely mottled throughout with various shades of brown, and are subject to great variety of colouring. 
INSESSORES.

CONIROSTRES.

FRINGILLIDE.

\section{HOUSE SPARROW.}

\section{Passer DOMesticus.}

PLATE LIII. FIGS. III. AND IV.

Although by no means one of those who would doom his whole race to pitiless destruction, the saucy pert old Sparrow is no favourite of mine, and there are traits in his character which are anything but estimable ; many a time have I been sorely tempted to visit some of these birds with vengeance, when for days together, and indeed the whole summer through, I have seen them quietly basking in idleness on a house top, watching the progress that my dear little friends the martins were making with their clay-built nests, and when all has been finished and made snug and complete within, pouning down upon them with the greatest coolness, and usurping the home which another's industry had raised.

There is a tale told, and it has been revived by $\mathrm{Mr}$. Jesse, in which it is stated, that once upon a time the martins themselves took summary vengeance upon one of these impudent intruders, and mustering in numbers to the rescue, walled the usurper in. The Sparrow is, I fancy, armed with too powerful a bill to be thus incarcerated alive.

The Sparrow is, no doubt, the most destructive of the feathered tribe ; and grievous, indeed, must it be, in some instances, to the farmer, to witness the inroads that they 
make upon his wheat; he is, however, too apt to forget the services they have done him by the destruction of countless caterpillars and grubs, which ought always to be considered in extenuation of the evil they are doing. In many parishes it has long been usual for the overseers to expend a portion of their funds in the destruction of Sparrows; there is, however, a parish near Bristol, the parish of Shirehampton, in which a subscription is got up for the extermination of birds generally, dooming all to destruction for the peculation of a few ; by the farmers, because in their ignorance they believe many of them to be noxious; and by the gentry because a few of them take a portion of that fruit which was intended by the Creator for the birds as well as them, and because they prefer the pleasures of appetite to the sweet music of the grove. The Sparrow adapts the form of its nest, with singular readiness, to the situation in which it is placed; this is most commonly in the spouts of houses, in old walls, sheds, and ruins, when it is very loosely put together; sometimes it builds in, or underneath, the nests of rooks and magpies; frequently in ivy against a wall, and also in firs and other thick foliaged trees, when its nest is very large and carefully constructed, and covered with a dome; it is composed of a quantity of straw and hay, and is thickly lined with feathers. The Sparrow lays four or five, and sometimes six, eggs; these vary very much between shades of neutral tint and brown, and are occasionally quite white. 

LIII *

$\therefore$

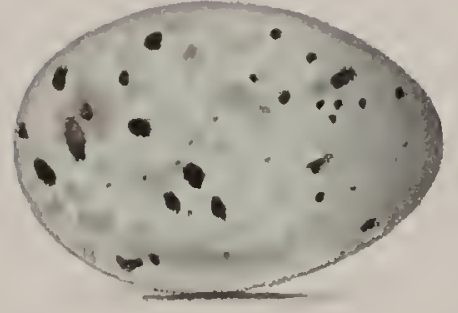


INSESSORES.

FRINGILLIDAR.

CONIROSTRES.

\section{PINE GROSBEAK.}

Pyrrhula enucleator.

PLATL LIII.*

The following quotations are from the pen of Mr. Wolley, to whom naturalists are again greatly indebted for having so perseveringly traced out and brought home to us the hitherto unknown eggs of this species.

"The Pine Grosbeak, though plentiful in Sweden during the winter, has been supposed to go to the east for the breeding-season; and, generally speaking, this is probably true; but in the northern and eastern part of Swedish Lapland, as well as in Finnish Lapland, a few Pine Grosbeaks make their nests."

Mr. Wolley made frequent excursions during the winter months in the hopes of finding old nests by which to guide his search in the ensuing spring, and on one occasion found one much like that of the turtle-dove, in a young fir-tree, six feet above the ground, which he had no doubt belonged to this species. "As the days grew longer I eagerly listened to the beautiful clear music of the bird in more than one locality; and one snowy morning I saw a hen watching me so very unconcernedly from a tree, that I climbed up to try to catch her in my hand. It was not until I nearly touched her that she flew off; as though she thought I was carrying the joke too far, but in a way that convinced me she had no nest. 


\section{FRINGILLID $\mathbb{E}$.}

"I had made arrangements for working another part of the country, but I left a trusty Lap in strict charge to visit a spot in Finland, where I had ascertained that in previous years the bird had bred. On my return to that neighbourhood at the end of summer, I watched day after day for the arrival of my faithful Lap. The nights were already becoming dark, when one evening I saw the well-known figure in a boat approaching our strand. I had scarcely shouted welcome before his wallet was in my hand, and my English friends and myself were in triumphal procession to the house. First, made its appearance, a grim wolf's head ; then came forth some reindeer gad-flies; next there was extracted an unknown nest; then a skinned Pine Grosbeak; and, at last, were carefully unwrapped from a little case the wished-for eggs, and there they lay in all their fresh discovered beauty before us."

One of the eggs figured is from a nest which was first found on the twenty-seventh of May. It contained four eggs, and was about six feet from the ground, in a young spruce fir-tree. It did not touch the bole of the tree, and the branches about it were thin, short, and open; and to identify them completely the hen was snared upon its nest.

"At Midsummer a nest was found with four fullyfledged young, about a hundred yards from the spot where the former nest had been. It is now in the British Museum. Externally it is made of remarkably open work of twigs and roots, generally in very long pieces. In the centre of the platform there is an inner bedding of barkless, fibrous roots, with a little of the hair-like lichen, which grows so abundantly on trees in Lapland forests." 
s

6

$\therefore$ 


\section{BULLFINCH.}

Pyrrhula vUlgaris.

PIATE LIV. FIG. I.

You will very rarely see the Bullfinch during the months of summer, unless you seek it in its sylvan haunts, amidst the thickest woods and copses, where it breeds, commonly choosing a blackthorn bush for the reception of its nest. I have rarely seen it in any other situation; it may sometimes, however, be found upon the fiat branches of yew and fir-trees. It is composed of moss and roots, lined with wool and hair, and much resembles the nest of the green-linnet, but differs from it in being formed upon a platform of sticks, in which it resembles that of the hawfinch and crossbill.

The Bullfinch lays four or five eggrs, much like those of the linnet, but having a blue ground-colour. It breeds in May and June. 
INSESSORES.

FRINGILLIDA.

CONTROSTRES.

\section{CROSSBILL.}

\section{LOXIA CURVIROSTRA.}

PLATE LIV. FIGS. II. AND III.

THE kindness of Mr. Arthur Strickland enabled me to figure an egg of the Crossbill in the "British Oology." This egg differs very considerably from that with which the liberality of Mr. Yarrell supplied me for the "Eggs of British Birds." On the former egg the spots are light, and of the colour of those on the various species of titmouse; the latter is, on the contrary, marked with a depth of colour, which distinguishes it from the eggs of the green-linnet, to which it bears much resemblance. Mr. Strickland's egg was taken, together with the nest, from the branches of a larch fir-tree, near his brother's residence at Boynton, near Burlington, in Yorkshire, during the summer of 1829. The nest was built of sticks, loosely put together, and crossed in a manner similar to that of the ring-dove, and mixed with white lichens, in the same way as the more clumsily-built nests of the hawfinch.

The eggs now figured are sent me by two kind friends. Fig. 2 is from Mr. Doubleday of Epping, who says that "the nest was nearly at the top of a spruce-fir, in a plantation just by the town. It was something like a greenfinch's, but had very little moss in it, being principally built of small twigs of larch, and lined with hair and a few feathers." An egg in the collection of Mr. Bond, 
from the same nest, does not differ from the one figured. Fig. 3 is from $\mathrm{Mr}$. John Hancock of Newcastle, well known to all those who admired his inimitable groups of birds in the late Crystal Palace. Mr. Hancock says, "On the 8th of May, 1850, Mr. Charles St. John and I took three nests of the Crossbill in the pine woods on the banks of the Findhorn, the young of which had flown. This year, 1854, I received from Mr. St. John a nest containing four eggs, accompanied by the two parent birds, which was procured on the 10th of March, in Rosshire. I have, therefore, now had an opportunity of examining four nests, three of which I saw in their natural position: these were all built in Scotch firs; the three first mentioned were placed on the lowest branch, about midway from the bole, they were all about ten feet from the ground; another nest, however, which I saw at Grantown, was built at so great a height that it could not be procured. The nests all agree in general appearance and structure. The following description is taken from the fresh nest with eggs:- "The nest rests on the branch in the midst of foliage which almost entirely conceals it. It measures, outside diameter, upwards of five inches; inside diameter, nearly three inches; depth of cavity, two inches and three eighths. The outside is formed of rather strong, dead twigs of the Scotch fir, loosely put together, next follows moss and wool, interwuven with rather long vegetable fibre. The inside lining is composed of delicate vegetable fibre." It is not easy to point out anything in either of these eggs to distinguish them from those of the greenfinch, except that they are more pointed at the smaller end than the typical eggs of that species. Fig. 3, except in size, may be considered to illustrate as well eggs of the greenfinch as it does those of the Crossbill. 
Mr. Long, of Hampton Lodge, near Farnham, who contributed the following account to Loudon's "Magazine of Natural History," tells me that the Crossbills left his neighbourhood soon after it was written, and have not been seen since, making good a remark of Mr. Hancock's, that these vagrant birds build their nests wherever they happen to be at the breeding season. "This day, 13th of April, 1839, I have had the satisfaction of receiving a nest with four eggs, from the Holt forest in this neighbourhood. This is the third nest that has been met with in the Holt. The first was taken with two eggs; and then, on the 7th of April, one with four young birds, apparently above a fortnight old, which would date the commencement of the nest early in the month of March. These three nests were all found in the thick top of a young Scotch fir, of about thirteen or fourteen years growth."

From Mr. Brown, of Cirencester, I have the fullowing very interesting information with regard to two nests of this species, seen by him in that neighbourhood in the spring of 1839. He had been spending the winter in Malta, and did not return home till it was too late to obtain their eggs. One of these nests was placed upon the lower branch of a Scotch fir-tree, about ten feet above the ground, and four feet from the extremity of the branch. The young ones, two in number, flew from. the nest when discovered, and were afterwards watched by Mr. Brown as the old ones came to feed them. This was on the 9th of April, so that the nest must have been built in February, and the eggs laid at the end of that month, or very early in March. "The outside of the nest was is framework of the dry twigs of the larch-fir ; from the base all round the sides within that frame, was laid a thick mass of bents, and slender stalks of wild 
plants, firmly felted together with wool; it was lined within with horsehair, nearly concealing the other materials. The outside twigs of larch extended in a loose way from three to five inches round the outside of the nest, on the margin of which, and hanging about the twigs, was a complete mass of the white freces of the young birds."

The other nest was built in a larch-fir, and was placed close to the trunk of the tree. It contained three young ones. These nests, it may be worth observing, were discovered in the same year as those mentioned by $\mathrm{Mr}$. Long.

Their very early period of breeding may account forwhat puzzled us at the time-our seeing the Crossbills whilst in Norway, during the months of May and June, always in flocks, most likely accompanied by their young ones. 


\section{STARLING.}

\section{STURNUS VULGaRIS.}

PLATE LV. FIG. I.

The Starling is an early breeder, and repairs to its accustomed haunts at the end of March, or beginning of April, to commence nidification. It builds its nest of dry grass, in the holes of trees, church steeples, ruins, old walls, and in dwelling houses, in cliffs by the seacoast, and not unfrequently in dove-cotes, and is in consequence accused of sucking the pigeon's eggs. The female lays four or five eggs, differing a little in size.

The most extraordinary assemblage of birds I have ever witnessed, is the gathering of Starlings at Kingsweston, near Bristol, mentioned by Mr. Yarrell. I have seen more birds at one time at several of the breeding places on the sea-coast, but never beheld so many of one species together. An immense body of Starlings make their roosting-place in the beautiful evergreen plantations, the property of Mr. Miles, and it is a sight well worth seeing to watch them arriving in an evening in dense and compact companies, each many thousand strong. It is strange, too, to hear the confused uproar raised by their noisy squabbles as they perch themselves for the night. You have only to call to mind the din occasioned by a dozen sparrows at bed-time, to have a slight notion of the noise and clamour of a great many thousand Starlings. 

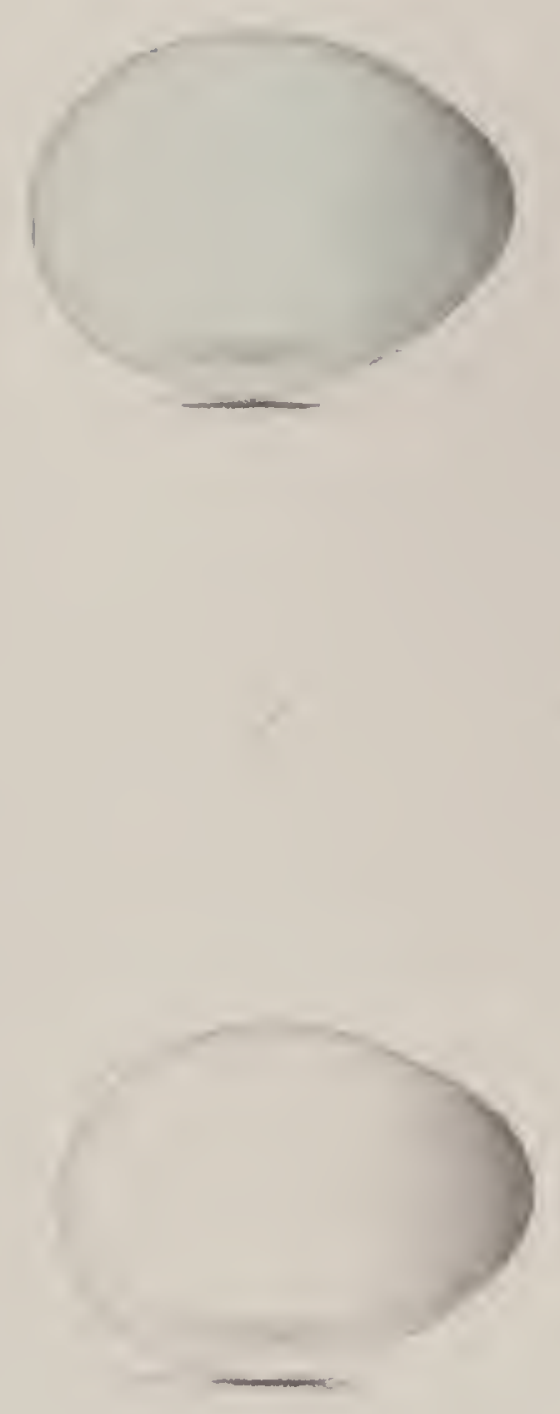

INSESSORES.

CONIROSTRES.

STURNIDA.

\section{ROSE-COLOURED STARLING.}

Pastor roseus.

PLATE LV. HIG。 Ir.

The Rose-coloured Starling can scarcely now be called rare as a British bird. Nearly fifty instances of its appearance in this country are on record. Mr. Yarrell mentions one in which the male and female were seen together in summer.

The only information with regard to its nidification which I have seen, is the following brief extract from Mr. T. L. Powys of Geneva, in the "Zoologist." "The nest of the Rose-coloured Pastor has been found three times in the canton of Geneva; the first instance was in the year 1810, at Naydan, near Salêve; the second at Vernoux, a village by the side of the lake of Geneva, in 1847; the third was in a hole in a nut tree, and resembled that of the common starling. The eggs are pure white, of the size and shape of those of the common starling, in whose company the Rose-coloured Pastor is generally observed hereabouts."

Mr. Wolley, in a letter to Mr. Newton, says, "Herr Nordman, an ornithologist from Helsingfors, informed me that he had formerly resided at Odessa, and that Pastor roseus was plentiful near there, rearing its young in holes in hanks; many pairs of birds breeding in company like sand-martins."

The egg which I have figured is from the collection of Mr. Walter. 
CONIROSTRES.

\section{CHOUGH.}

RED-LEGGED CROW.

Fregilus graculus.

PLATE LVI.

To the persevering kindness of the Rev. W. D. Fox, I was indebted for the egg from which the drawing in the "Oology" was made at a time when these eggs were scarcely known, together with the nest which contained five eggs. The Red-legged Crow is tolerably frequent round the British islands. It abounds on the Isle of Man; is said to breed on the western isles of Scotland; is met with sparingly near Berwick-on-Tweed, and on the coasts of Devonshire and Cornwall. Mr. Fox has also observed them on all the steep rocks and promontories of the Isle of Wight, and on the noble cliffis of the Isle of Purbeck in Dorsetshire. Mr. Henry Doubleday saw them during the breeding-season on the northern cliffs of the Isle of Jersey.

It is, notwithstanding this general distribution, a matter of some difficulty to procure its eggs; and it was not till after some years of fruitless endeavour that Mr. Fox succeeded in obtaining them, arising from the "excessive caution the birds employ in selecting their places of nidification. These are always on the frce of the steepest cliffs, and in general in clefts far in; the passage to which 

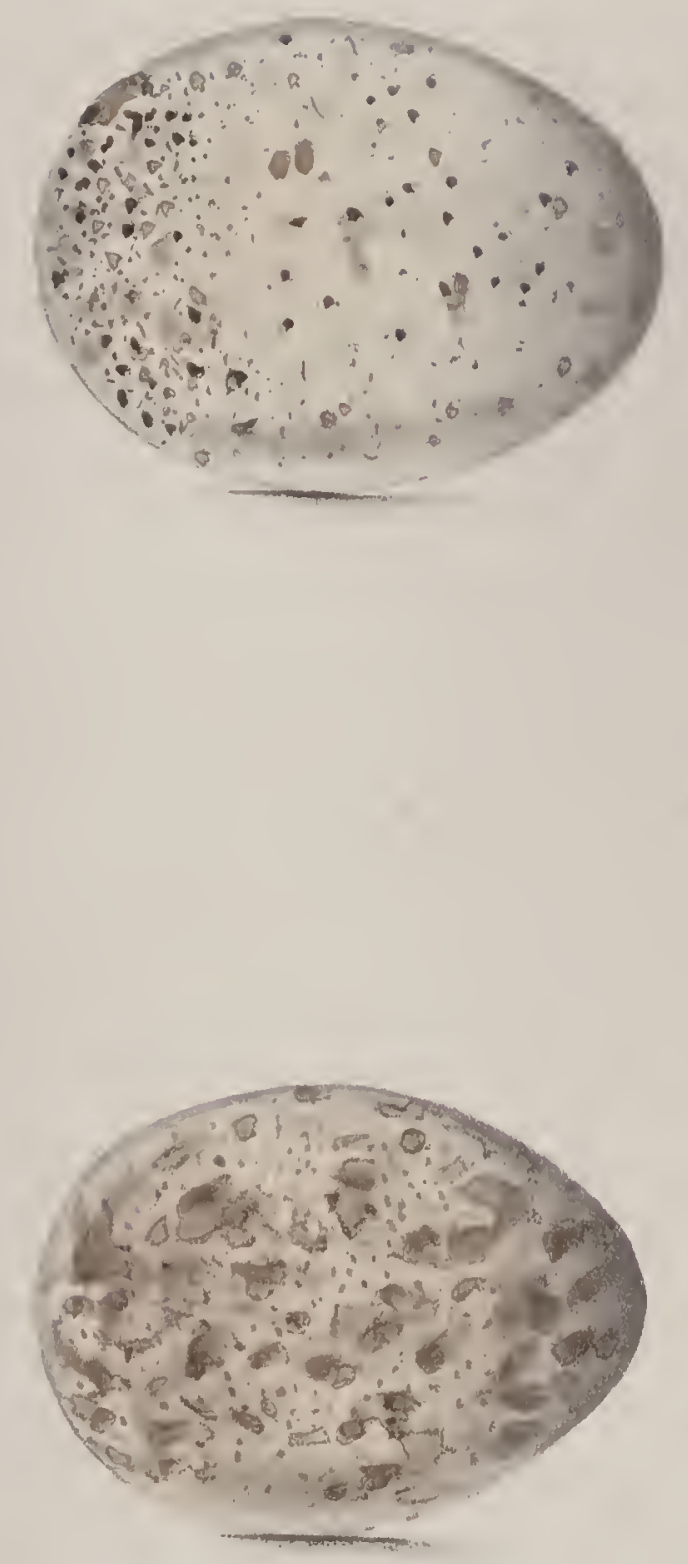

turns at right angles frequently, so that you cannot reach the nest, or even see it." He adds: "I obtained a young one, which I much regretted losing, as he promised to be very clever, and attached to me; he followed me very well, and seemed to have all the cunning of the magpie." Montague mentions an instance of a pair of Choughs which bred for many years in the ruins of Crow Castle, in the Vale of Llangollen; and 'lemminck says that they breed on trees, though rarely.

The nest is composed outwardly of sticks, succeeded by a quantity of roots and dry grass, lined with very fine roots, grass, and wool.

The eggs of this species are easily known from those of any of our crow-kind; they are most like those of the magpie, from which they differ in their greater size and more ochreous colouring. Fig. 1 is, I think, the most characteristic egg. Fig. 2 is unusually crowded with spots; it is from the collection of $\mathrm{Mr}$. Bond. 


\section{RAVEN.}

\section{Corvus CORAX.}

PLATE LVII.

The Raven, which a few years ago used to breed in old ruins, and even in some of our church-steeples, is now only to be met with far distant from man's abode, leading a solitary and persecuted life : it is in consequence one of the shyest and most wary birds in this country. In Norway, on the contrary, where the feathered tribes are loved and cherished, they so abound, that we at one time counted as many as eighteen together; there they are pert and confident, and would frequently remain quietly seated till we had passed them at a distance of a few yards. On one island which we visited we saw several of their nests in a large sepulchral-looking cave, peculiarly suitable as the residence of birds which, in some districts, are regarded as of ill-omen.

At home the Raven breeds in the most wild and inaccessible districts, building its nest, for the most part, in the steepest cliffis upon the sea-coast, sometimes, when inland, upon lofty trees. They have for a great many years been known to breed in the mausoleum at Castle Howard, in Yorkshire.

The nest is large, and composed of sticks plastered together with mud, and lined with a quantity of roots, wool, and the fur of animals. 

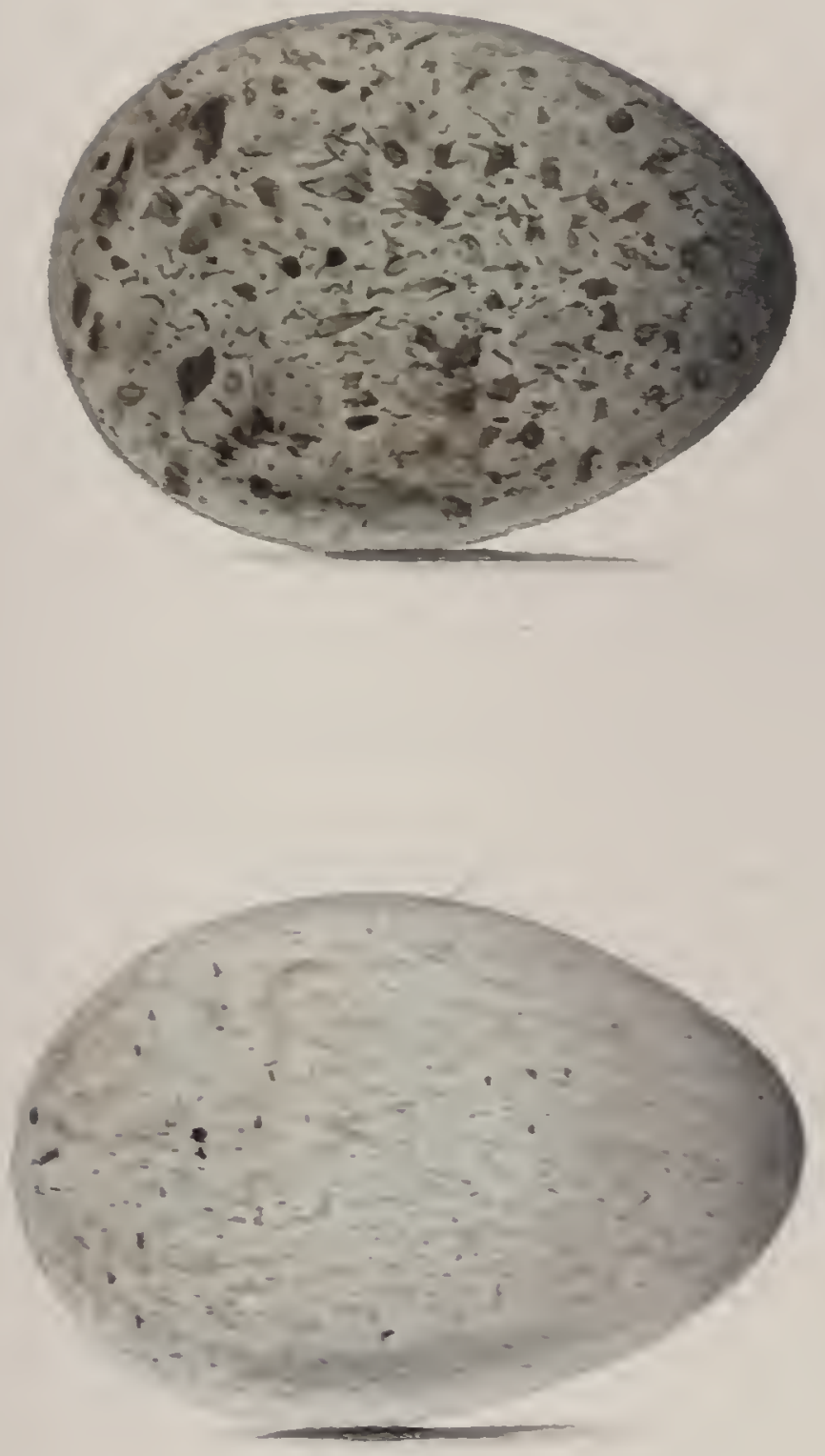

The Raven is one of our earliest breeder's, and frequently rears its young ones under some of our most inclement skies. The eggs are four or five in number, and go through two or three varieties intermediate to the figures of the plate; some are distinctly and more sparingly spotted and resemble somewhat eggs of the jackdaw.

Mr. Newton has sent me the following graphical notes:

"A pair of these birds breed annually in this neighbourhood, and I naturally take great interest in them, and have thus become acquainted with much of thier history for some years past.

"When undisturbed they have usually refurnished their last year's nest, always lining it neatly with rabbits' down. It is built on one of some lofty Scotch fir-trees standing far out on a heath. The number of eggrs laid is generally five, but I have known them to be content with four; while, on the other hand, six were once deposited. While the hen is sitting, the actions of the male bird are well worth watching: he dashes indiscriminately at any bird that approaches, be it stock dove or perigrine falcon, and when the intruder has been utterly routed, he shoots back to the nest, celebrating his victory by a sonorous croak, turning, as he utters it, completely over on his back, an action which does not, however, in the least degree impede his onward career. He then resumes his look-out station on one of the highest boughs, perhaps leaving it again at the expiration of a few minutes to repel another invasion." 
INSESSORES.

CONIROSTRES.

\title{
CARRION CROW.
}

\author{
CORBIE CROW, BLACK NEB.
}

Corvus CORONE.

PLATE LVIII. FIG. I.

Some years ago a controversy took place between $\mathrm{Mr}$. Waterton and Mr. Rennie, with regard to the habits of the Carrion Crow-Mr. Rennie maintaining that the bird is in the habit of covering its eggs during absence, and Mr. Waterton denying the correctness of the statement. $\mathrm{Mr}$. Waterton, as is well known, has spent much of his life amongst the feathered tribes, either in this country or abroad. When at his own residence, no one, perhaps, has so good an opportunity as he has of studying the habits of our British birds; for all the most persecuted tribes of which, his park is a refuge and a home; there the hawk, the crow, the owl, and the magpie, treated as vermin and brutally butchered by the gamekeepers of other English gentlemen, are alike unmolested.

It was always, at school and for many years after I left it, a habit with me to look into every bird's nest within my reach, and I have very rarely passed the nests of the magpie or the crow without indulging myseif with a peep at their contents, but I have never seen the eggs of the latter covered, as mentioned by Mr. Rennie.

The Carrion Crow builds its nest in deciduous trees 
LVIII
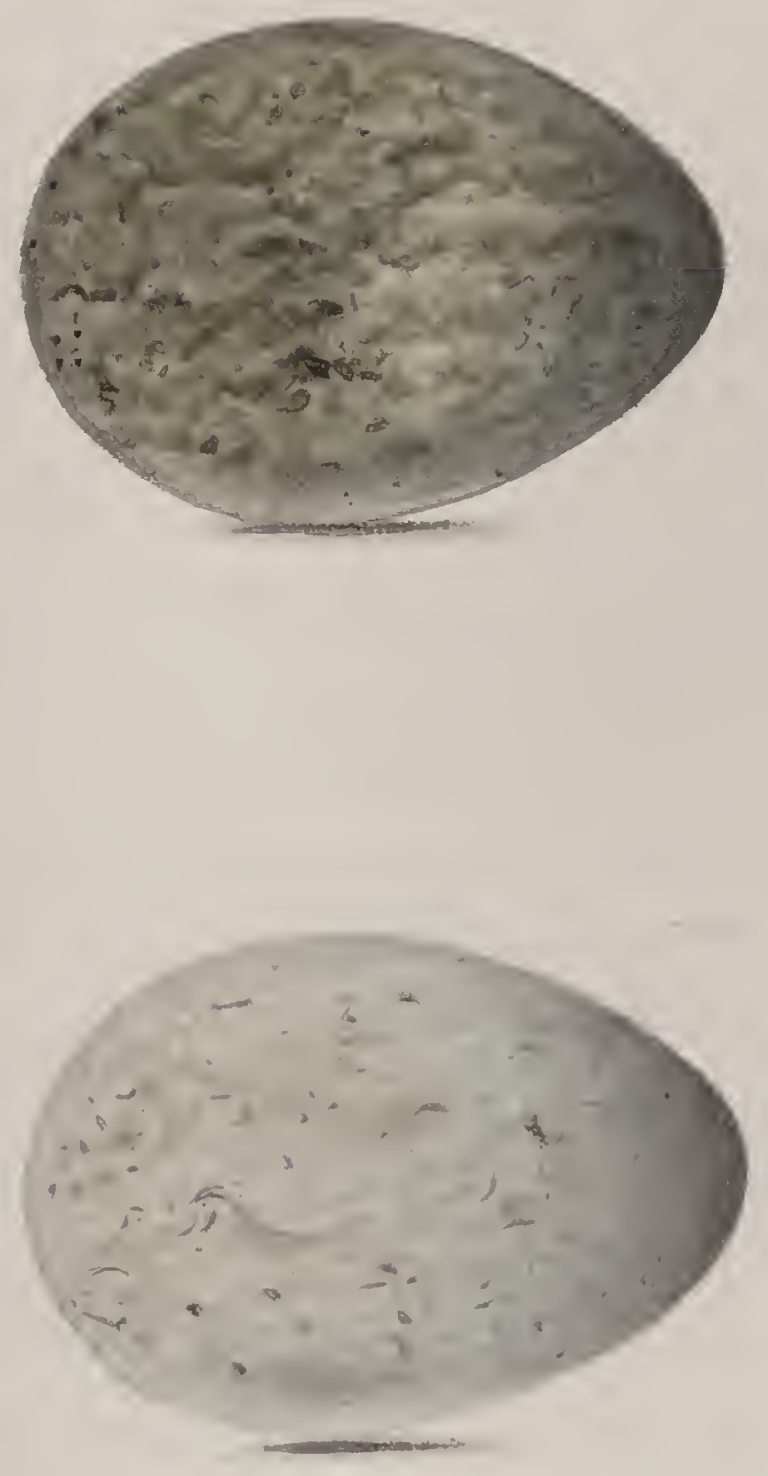

chiefly, sometimes in a thick fir-tree; it is made of sticks, strongly cemented together with clay; it is then lined with roots, and afterwards with a large quantity of wool, the fur of animals, and other soft materials, often two or three inches thick. The eggs are four or five in number, and greatly resemble those of the raven, the hooded crow, and the rook. From those of the rook it is at times very difficult to distinguish them; they are, however, usually a good deal larger. They vary much from the deeplycoloured egg of the plate to a light tinted variety, similar to that of the hooded crow now figured. Some are of a light blue, without any spots whatever, marked here and there with undertints of grey. I have chosen the figures of the plate that they might not only represent each its own species, but that of the nearly allied species as well.

In 1832 a pair of these birds took a singular fancy into their heads : deserting the habits of their forefathers, and the society of their species, they repaired to one of the Fern Islands to breed, apparently thus subjecting themselves to very great inconvenience. Contrary to their usual habits, they built their nest upon the ground, there being no trees on the islands; it was of most curious con-. struction, and instead of the sticks of which it is in other instances composed, which the neighbourhood would not supply, the outside of the nest was formed of small pieces of turf, neatly laid upon each other, and formed into a compact wall; the space within was lined with a quantity of wool, which was all brought from the mainland, at the distance of four or five miles. 


\title{
HOODED CROW.
}

\author{
ROYSTON CROW.
}

CORvus CORNIX.

PLATE LVIIJ. FIG. II.

The Hooned Crow is a rare bird in England during the summer months; a few instances only being recorded in which it has remained so far south to breed. It is, then, not uncommon in Scotland, and is sparingly dispersed through the Orkney and Shetland Islands. The Hooded Crow has been known to breed near Scarborough, and also in the neighbourhood of Berwick-onTweed. It seems to accommodate itself with indifference as to the position of its nest. In Scotland it is found, according to Mr. Selby, in trees, rocks, and precipices on the sea-shore. In Shetland, where trees do not exist, and it would be as difficult to find a stick, the Hooded Crow builds its nest upon the cliffs, or single rocks, stacks as they are there appropriately called, which are surrounded by the sea; and resorts to the same substitute as the eagles, forming it of the long and very flexible branches of the larger sea-weeds, and lining it with quantities of dry grass, wool, hair, and other soft materials.

In Norway they inhabit here and there the boundless, forests, but never at any great distance from the sea, 
arising, probably, from their partiality to shell-fish. On one of the islands at sea we found a solitary pair, which had got their nest in a rock, in the very camp of their enemies, the sea-gulls, which took every possible opportunity of annoying them, and, upon our driving one of them from the nest which contained eggs, persecuted it without mercy. One of the eggs was hatched, and another just chipped. We wished much to obtain the shell without causing the death of the young one; and, in order to accomplish this, my companion, Mr. John Hancock, performed the accouchement most admirably with a lancet, leaving the young Crow sprawling uninjured at the bottom of the nest.

The eggs are four or five in number, and do not differ from those of the carrion crow and rook, except in size. In shape and colour they are more nearly allied to those of the rook, and are subject to the same jackdaw-like variety as the other species. The egg of the carrion crow, figured in the plate, is intended to represent the typical appearance of those of this species; the lightcoloured egg of the Hooded Crow, a variety to which they are both subject. 
INSESSORES.

CONTROSTRRS.

\section{ROOK.}

\section{Corvus FrugILEGUS.}

PLATE LIX.

The Rook is one of those birds which, courting the society of man, has become almost as familiar to us as the domestic poultry which we rear.

Its noisy presence in the spring adds one of the great charms to a country life; and how much of the venerable respectability of some of the finest old halls and mansions in our land would be lost without it! The old rookery, which has for centuries been the gathering-place of generations of these birds, is almost as inseparable in our ideas from some of the old homes of England, as the stately avenue by which we approach them.

During the first bright days which foretell the early opening of the spring, when the thrush alone has hailed its approaching glories with a glad song of welcome, the cheerful cawing of the Rooks, as they take possession of the well-known trees, breaks upon the ear, which is open to the simple music of Nature, with a peculiar charm.

The jealous bickerings which take place, as each one is anxious to secure to itself some favourite bough, the frequent fights which occur before a proper understanding is established amongst them, and the general attack upon, and destruction of, the nest of some one which has broken 


\section{I.IX}
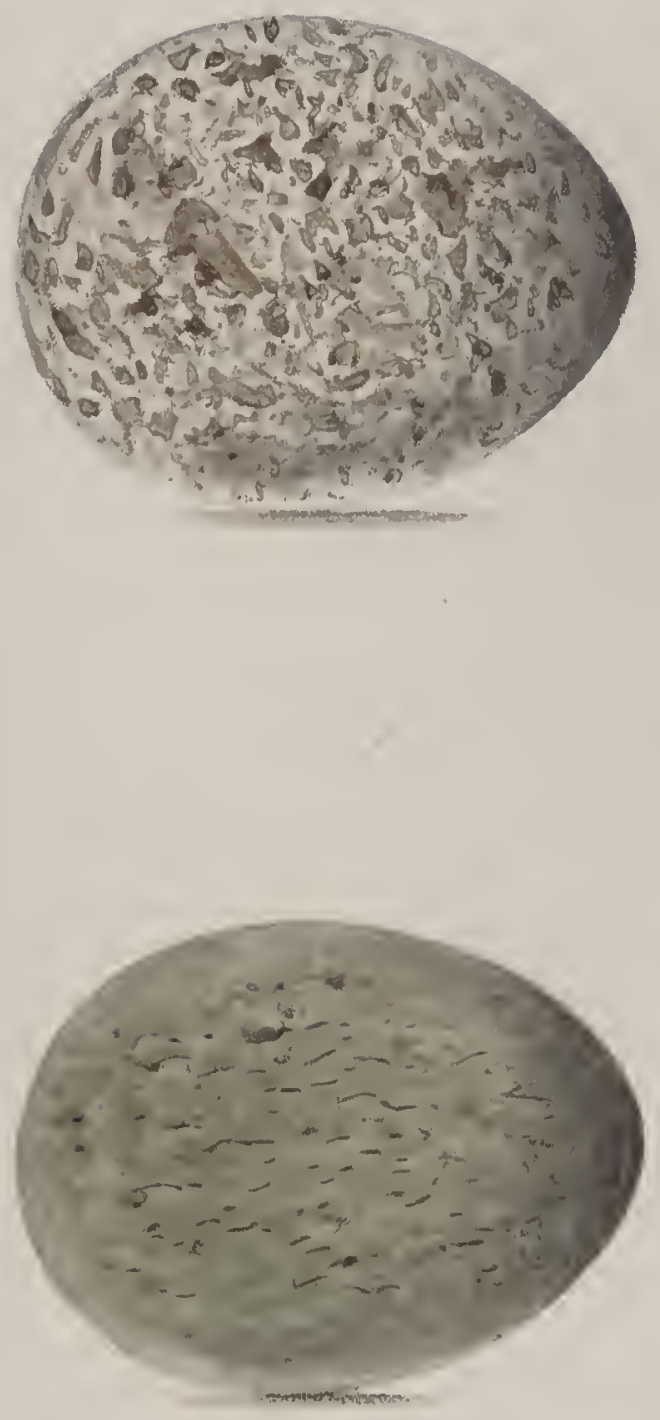

the laws of the community - all may afford scenes of constant amusement.

The thieving propensity, so curious a characteristic of the genus, of which the Rooks inherit their full share, leading them to pilfer from each other's nests, is, ton, the source of many a broil in the rookery.

That the Rooks have laws amongst themselves, by which to regulate the society, the following anecdotes, given by Mr. Jesse, will sufficiently point out. Speaking of the Rooks at Hampton Court, he says, "they are very particular that none of the society build away from the usual line of trees. A pair did so one spring; and, when their nest was finished, at least fifty other's came and demolished it in a few minutes."

He mentions another instance of a pair of birds which, though only separating themselves so far from the rest of the community as to build their nest in the lower branches of the same trees, were nevertheless pertinaciously persecuted by the others; having their nest destroyed by them no less than twenty-two times before they were permitted to complete it. He adds, that he has always observed that, if a pair of Rooks attempt to make their nest apart from the rest of the fraternity, and in a tree not used by them before, the other birds invariably pull it in pieces. A similar occurrence took place near a cottage which I once occupied on the Hampstead road. A pair of Rooks built their nest at the top of a tall ash-tree. It was completed, and all seemed to prosper with them-but the evil day soon came; their elopement had been discovered; the place of their retreat traced: they were pursued by a large party of their comrades, and the nest which they had constructed with so much anxiety, was pulled to pieces in a few seconds.

It is not to the rookery alone that their presence im- 
parts an interest. They may be watched as they scour the country round in search of materials for their nests, visiting each tree in its turn, and breaking off and rejecting numerous branches, till the one suitable to their purpose is obtained. The elm, the branches of which are pliable and easily broken off, is their favourite tree, and of its twigs their nests are chiefly formed. I have many times watched them when overladen with too large a branch, after many an ineffectual struggle to reach their nests, borne away headlong before the wind, till at last compelled to let it drop.

It is, too, an interesting sight in the neighbourhood of a large rookery, to watch these birds as they homeward wend their way in an evening after a long day's forage in the fields, and to mark, as I have often done, the exactitude with which, for a number of evenings together, they will keep to the self-same track, and vary that track according to the season of the year. I was led to notice this more particularly by being told by some friends of mine, who had observed them for many years, that at one season of the year, the spring, the Rooks invariably make their homeward flight so nearly above their residence as to be just seen from the front windows; and that, in the autumn, they always go a little behind the house.

Amongst our farmers are to be met with some of the most ignorant and prejudiced of men, and to that ignorance is to be attributed the most unjust and, to their own interest, detrimental persecution that the Rook has met with at their hands.

That it does occasionally consume a portion of the grain after it is sown, there can be no doubt; but the injury to the forthcoming crop has been fair more than counterbalanced by its destruction of grubs when the field was ploughed. In one instance which I will men- 
tion-for I have no wish to do them more than justicetheir consumption of the seed-corn had been very considerable. This was, however, during a seasson which, remarkable for its drought, had caused a scarcity of their usual food, and was a rare instance, there being no notice of this habit of the Rook of which I am aware, with the exception of one during the same spring, in the Magazine of Natural History. I had occasion to visit a rookery for the purpose of obtaining varieties of the eggs to draw; and, when looking out for the tree which presented the fewest difficulties to climb, I was much surprised by observing the ground beneath them strewed with pellets composed of the shell of the oat, and similar to those disgorged by owls. In quantity they would have filled some bushels; but it must be remembered that these were gathered from many a hundred acres round.

The time at which the Rook meets with the bitterest persecution is just when it is doing the greatest good; and, when mercilessly shot down by the ignorant farmer, is heaping coals of fire on his head.

I remember once having pointed out to me by a farmer, who lives near Alnwick, one of his fields which was then black with Rooks; and, to prove to me the mischief they were doing him, he led me to the spot. It was a grass field, and, sure enough, the place bore evidence of destruction; its lovely green was gone, and scarcely a blade of grass remained standing. The Rooks had pulled up the entire surface of the already dead turf, and were regaling themselves upon the myriads of grubs which now lay beneath it, which had done all the mischief by eating the roots of the grass asunder; and, but for the timely interference of these useful birds, another summer's increase of their ranks would have enabled them to carry devastation far and wide. 
Mr. Apperley, who farmed a property attached to one of the largest rookeries in this country, at Bilton Hall, near Rugby, thus witnesses in their favour: "So large, indeed, is this rookery, as to have given the name of 'Bilton Rook Feast' to a kind of wake held in the village at the time the young birds are considered fit to eat. Independent of the climbers, the gameleepers of several neighbouring gentlemen used to attend with their guns; and I have known upwards of a hundred dozen birds taken of a morning. I am, however, enabled to say that, numerous as these birds were, I never found injury from them to my crops."

Rooks seem greatly to prefer those trees which are lofty, and near some dwelling. At times they, however, deviate rather whimsically from their usual habits. There are several instances of their building in trees of a lower growth, as in the case of a rookery mentioned by Mr. Rennie, in the Duke of Buccleuch's grounds at Dalkeith, where they built in young oak-trees, none of which were more than ten or twelve feet high, although large trees were abundant in the neighbourhood.

There are a few trees in one of the streets in Newcastle, which have long been crowned by the nests of these birds; but during the spring of 1832 , several pairs, dissenting from some of the proceedings of their neighbours, left their ancestral trees, and built their nests amongst the smoky chimneys of the nearest houses. But, perhaps, the most remarkable instance in ornithological architecture is that mentioned by Bewick of the pair of Rooks which, for ten successive years, built their nest and reared their young ones on the weather-cock of the Exchange spire, turning about with every change of wind.

The nest of the Rook is built of sticks cemented with clay, mixed with tufts of grass, and is lined with roots. 
The eggis are four or five in number, and vary much; they are broader in proportion to their length than those of the raven, and carrion and hooded crows: they are sometimes thickly mottled all over, like eggs of the raven; sometimes suffused with green, like those of the carrion crow, and sometimes much like eggs of the jackdaw. 


\section{JACKDAW. \\ Corvus monedula.}

PLATE LX. FIG. II.

THE JACKDAW builds its nest in many opposite situations; most commonly in holes of ruins, in lofty church steeples, being numerous in our cathedrals; in cliffs and precipices, and sometimes in holes of decayed trees. In addition to these localities, Mr. H. T. Frere states in the "Zoologist," that he has seen a nest of this species about thirty feet from the ground upon a bough close to the bole of a silver fir-tree. A most curious instance is mentioned by White in his "History of Selborne," in which he states that a race of these birds took it into their heads to breed in the burrows of a rabbit-warren.

The nest is composed of sticks, lined with wool, dry grass, and such like materials; an almost incredible quantity being sometimes used to form its foundation in a chimney or hollow tree, and raise it to the required height. Mr. Wolley says that he saw the nest in the turret at Eton, mentioned by Mr. Jesse; that it was, he believes, raised no less than nine feet from its foundation; "taking its rise from two or three steps of the circular stairs, it was built up compactly, and of a nearly uniform breadth, to a lancet window in the perpendicular wall, the bottom of which window was not otherwise sufficiently wide to support a nest." The eggs are four or five in number, and do not differ materially. 
Mr. Wolley, referring to the point in dispute, whether or not birds of the crow kind cover their eggs, says, in the "Zoologist," "I have a fact to offer on this disputed point. About ten days ago, Henry Walter and myself amused ourselves by climbing up to Jackdaws' nests placed in holes in the trees about Bearwood, which is on the borders of Windsor Forest. In the course of three days we must have examined several score of nests. On the first day none of the eggs were covered, but on the second and third days, we found that several of the nests, that had been visited before, now had their eggs either partially covered by loose pieces of wool, or the eggs, in some cases, were nearly buried in the woolly lining of the nest, and this, whether the bird had just flown from the nest or not." 
INSESSORES.

CONIROSTRES.

\section{MAGPIE.}

PIANET.

Pica caudata.

PLATE LX. FIG. III.

THIs elegant and well-known bird is another of those which are in this country doomed to the most exterminating destruction, because they exercise those instincts which are implanted in them by the God of Nature. It has become with us, in consequence of its persecuted life, and contrary to its natural disposition, one of the shyest and most wary birds we meet with : a little of its nature will, however, even here prevail, in its selection of those trees for its nest which are near some human dwelling. In Norway, a country where it meets with nothing but kindness, it is upon the most familiar terms with the natives. In the town of Drontheim it builds its nest under the eaves of their warehouses, and on their churches; upon the roofs of which, and the surrounding tomistones, a dozen of them may be seen at one time.

In the country, and even upon the islands adjacent to the coast, we scarcely saw a single house without two or more of these lively birds, which commonly build their nests under the very eaves, or in some stunted tree close by, where the nests are piled upon each other for many feet in depth, the accumulation of the undisturbed and quiet possession of many years. 
We were always delighted with the kind feeling evinced by the inhabitants of Norway towards the feathered race: in some of their houses, holes are cut for the admission of the starling; against others pieces of wood are nailed to support the nest of the house martin. At Christmas, too, sheaves of corn are placed upon the roofs of their houses, that their feathered friends may join in the general festivity of the season. It is in consequence of this kindness that the Magpie walks into their houses with pert confidence. In no instance did we see one in the forests far from man's dwelling-place; on the contrary, its appearance was always a sure and welcome sign of our vicinity to some house.

The Magpie builds its nest for the most part in trees; sometimes in thorn-bushes and hedges, at a few feet only from the ground. The Rev. J. Hall gives the following interesting account of a nest of these birds which he met with in Scotland: "On the road between Huntly and Portsoy, I observed two Magpies hopping round a gooseberry-hush in a small garden, near a poor-looking house, in a peculiar manner, and flying out and into the bush. I stepped aside to see what they were doing, and found, from the poor man and his wife, that these Magpies for several successive years had built their nest and brought up their young in this bush ; and that the foxes, cats, \&c., might not interrupt them, they had not only barricaded the nest, but had encircled the bush with briars and thorns in a formidable manner."

Some have supposed that those Magpies which build their nests in hedges are of a distinct species, and Mr. Wilmot tells me, that he has usually noticed that their eggs were less. My own experience does not corroborate his observation. In firmneiss of texture and strength of construction, no piece of architecture of like materials 
can at all vie with the nest of the Magpie: its outside is of thorns arched over, and so compactly put together, that it is by no means an easy matter to force an entrance for the hand, except at the proper doorway; the state of my hands during bird-nesting time at school would have frequently borne evidence of the fact. The nest is so thickly cemented at the bottom, and plastered inside with clay, that, when placed at the top of a high tree, shot will scarcely penetrate it; the lining is composed of fine roots: the eggs are six or seven, and rarely eight, in number : they differ much, both in colour and in size. They are sometimes larger than the one figured, and more sparingly spotted; sometimes very little larger than the eggs of the jay, and almost as thickly freckled throughout. 


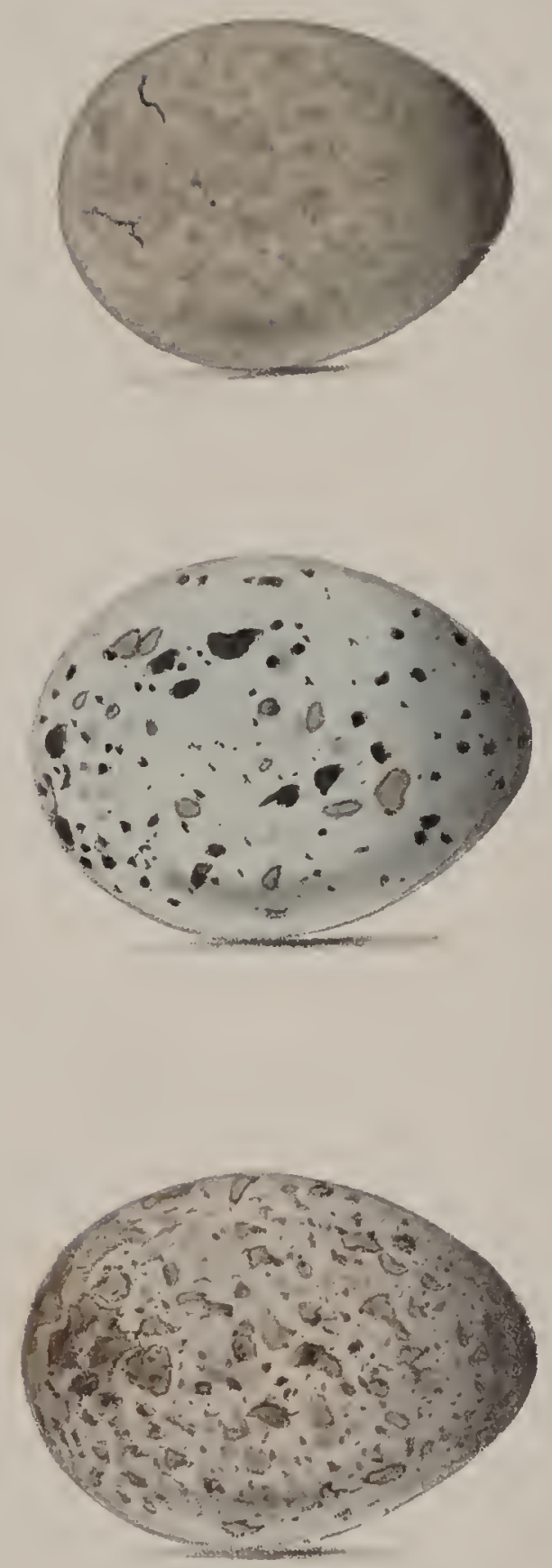
INSESSORES.

CONIROSTIIES.

CORVIIIR.

\section{JAY.}

\section{Garrulus glandarius.}

PLATE LI. FIG. I.

THE harsh cry of the Jay, "discordant heard alone," if not disagreeable, is to myself, at least, unaccompanied with any of those delightful sensations which the wild wood-note of every other bird never ceases to impart. I speak in ignorance of the more agreeable notes mentioned by Montagu, never having heard any other than the loud, peevish, quarrelsome sort of cry which it mostly utters. The Jay is usually a very shy bird, and difficult to approach, hides, during the breeding-season, in the thickest and least frequented part of our woods, and builds its nest upon the boughs of a low tree. A pair of birds built their nest in Oatlands Park two years ago, placing it near the top of a tall Scotch fir-tree. It is formed of sticks, lined with fine roots, and is, in some instances, very compactly put together.

The eggs are from four to six in number, and differ considerably; but, as from their size they cannot easily be mistaken for those of any other bird, I have not thought it necessary to figure any of the varieties; they are frequently much darker, as well as lighter, than the plate; are sometimes much browner in their colouring, and not unfrequently encircled towards the larger end with a distinct ring of darker spots; in some instances, this ring is near the smaller end. 
INSESSORES.

PICIDA.

SCANSORES.

\title{
GREAT PLACK WOODPECKER.
}

\author{
Picus martius. \\ PLATE LXI. FIG. I.
}

To the several instances mentioned by Mr. Yarrell, in which the Great Black Woodpecker has been seen in this country, I may add one, communicated by Mr. T. Meynell of York, who says that he well remembers having seen a pair of these birds in the pleasure-grounds attached to the Friarage, his father's residence at Yarm, in Yorkshire.

We saw them but twice in the Norwegian forests, looking, when flying at a short distance, much like a crow; their nesting-places were like those of the other species, in holes in the trunks of trees. The eggs are, according to Temminck, three in number; they are, like those of all our species of woodpeckers, of a pure white and glossy, as though they har been varnished. To the kindness of Mr. Wilmot I am indebted for the use of this rare egg to draw. 
IXI

1
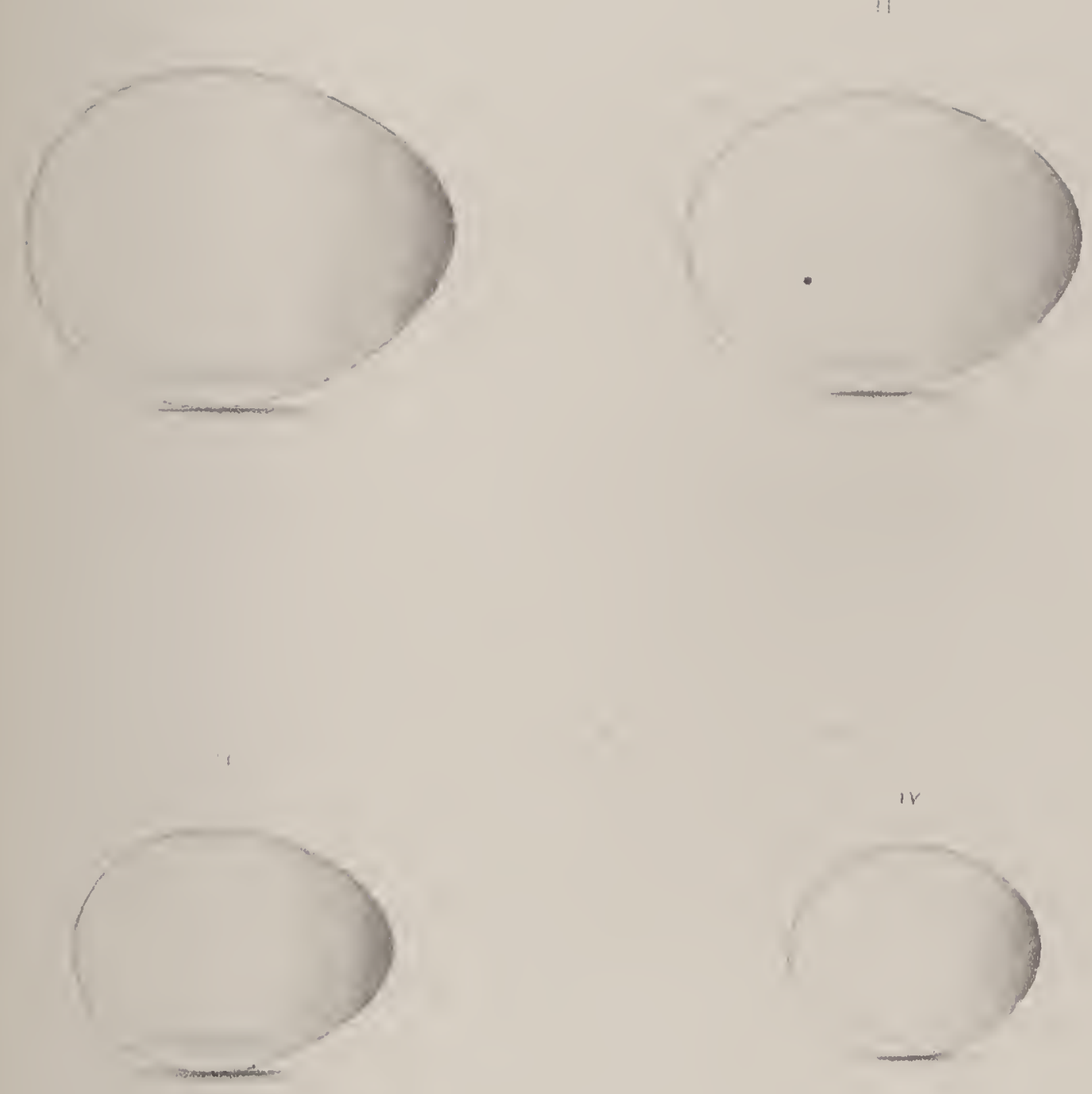

INSESSORES.

SCANSORES.

PICIDAE.

\section{GREEN WOODPECKER.}

RAIN-PIE。

\section{PiCUS viridis.}

PLATE LXI. FIG II.

The Green Woodpecker very soon makes known its neighbourhood by its loud and very singular cry, which is the more remarkable in rainy weather; the loud laughing note which it then utters has often almost reconciled me to a wet jacket.

The Green Woodpecker builds its nest in the trunks of trees, frequently at a considerable height above the ground. In Norway, where the churches are chiefly of wood, we noticed one of these birds, which had chosen for its nest the elevated situation of the spire, in the side of which it had most irreverently bored its hole.

This hole is frequently so small that the eggs are accessible only after the long and laborious use of the hatchet; they are four or five in number, and are laid upon the fine particles of the rotten wood which remain at the bottom of the hole.

Mr. Newton has kindly sent me a drawing of the coloured eggs of this species mentioned by himself and others in the "Zoologist." It is smeared over in the same manner as the eggs of the grebes, and I have no doubt at all arises from a vegetable stain. 
INSESSORES.

SCANSORES.

\title{
GREAT SPOTTED WOODPECKER.
}

\author{
PiCUs MAJOR.
}

PLATE LXI. FIG. III.

The Great Spotted Woodpecker is either a rare or local bird, or one which most effectually evades the sight; for much as I have been out in the fields, and always on the watch for such things, it has very rarely been my lot to see it alive, and I have eagerly looked for it in places where the green woodpecker and wryneck were very abundant.

Never having myself seen a nest of this species, I have recourse to the infurmation of $\mathrm{Mr}$. H. Doubleday, of Epping, who is ever on the look-out for anything curious in natural history, and ever ready liberally to impart to others the information thus gained. He notices the rarity of the bird even there: "The Great Spotted Woodpecker is a rare bird here, and I have seen only three of their nests; these were all in the horizontal branches or arms of oaks, where a smaller branch had been broken off, and the part had decayed; the place was carefully plastered up, so as only to leave a hole just large enough for the bird to enter; in one instance, where the arm was hollow, the nest was nearly three feet from the opening. The eggs, five in number, were laid upon the bare wood, which was decayed and soft." 


\section{LESSER SPOTTED WOODPECKER.}

\section{PicUs Minor.}

PLATE LXT. FTG. IV.

LIKE the closely allied species preceding, the Lesser Spotted Woodpecker breeds in the holes of trees, laying its eggs, which are, according to Montagu, five in number, upon the bare rotten wood, and sometimes at a considerable distance from the entrance of the hole.

Mr. Thurnall, who takes the nests of this species near Whittlesford, in Cambridgeshire, has obligingly sent me the following particulars. He says that he has generally seen the nests in the dead branches of the tree, but also in the living trunk; they are made by the birds themselves, and are usually from twelve to twenty-five feet above the ground; but that one which he found in a pollard willow, was only three feet high. When these holes occur in the dead branch of the tree, they are first bored at right angles to the branch till they reach its centre, when they pass along it for from twelve to twenty inches. The eggs, five in number, are laid upon the bare wood about the middle of May. 


\title{
WRYNECK.
}

\author{
YuNX TORQUILLA.
}

PLATE LXII. FIG. I.

THE cry of the Wryneck is as singular as that of the green woodpecker; and, in some instances, very closely resembles that of the kestrel hawk. It makes its nest in the holes of trees, and seems partial to those of the apple-tree, chiefly frequenting orchards during the breeding season: it usually lays seven eggs, and Montagu says, extends them to nine or ten in number. Mr. Salmon mentions a remarkable instance, in which he took no less than twenty-two eggs from a nest of this bird, robbing it of the eggs at five different times.

Although I have spent much of my life in the country, and have been always on the look-out for it, I have rarely seen the Wryneck well, and was, therefore, the more surprised when, in going one day along a public road, I passed two of them seated side by side on the top of a stake fence. 
LXII

S.:

$\therefore \%$.

औa
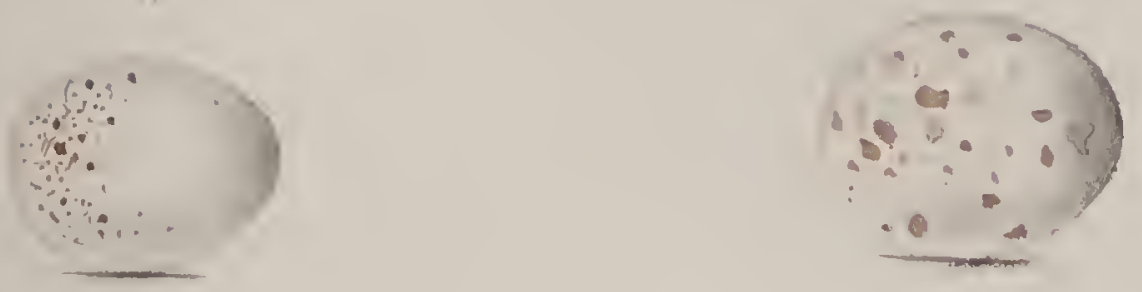

INSESSORES.

SCA NSORES.

\section{CREEPER.}

Certhia familiaris.

PLATE ISII. FIG. II.

THE eggs of the Creeper resemble almost as closely those of the blue and marsh titmouse, as some of the eggs of the nuthatch do those of the greater titmouse; they are, however, usually rather longer in proportion to their breadth, and have the spots more concentrated at the larger end: if mixed with eggs of the titmouse, and even with some of those of the willow-wren, it would be very uncertain work to separate them.

The Creeper builds in holes of trees, in such places as those out of which a branch has been torn, or where the bark protrudes from the tree, leaving sufficient room behind it. White mentions a nest which was built against a house-end, behind some loose plaster.

The nest is formed of dry grass and bits of moss, very loosely put together, and lined with feathers. Mr. Yarrell thus describes one of which he has added a drawing in his work. "It is formed, on the outer surface, with small twigs, within which there is a thick layer of fine grass, mixed up and lined with black wool and a few small dark-coloured feathers."

The Creeper breeds early, and lays from six to nine eggs. 


\title{
WREN.
}

\author{
KITTY WREN.
}

\section{TROGLODYTES VULGARIS.}

PLATE LXII. FIG. III.

THE nest of the Wren is of an oval form, arched over, and protected on every side. It is a most beautiful specimen of strength, warmth, and neatness, and so compact and closely interwoven, that one in my collection might be kicked about the floor without much disarranging or disuniting those minute particles of moss of which it was first formed. It is usually constructed of green mosses ; and from its close resemblance to the situation in which it is placed, is admirably protected from discovery. Its position is most commonly against the moss-grown side of a rock, a bank, or an old tree, in the decayed sicle of which the nest is formed; and, but for the small hole of entrance, would be regarded as only a portion of the tree. I have found it on the lower branch of a spruce fir-tree in the middle of a furze-bush, and constructed chiefly of dry grass, sometimes covered outside with ferns; and not unfrequently against the side of a clover stack, formed entirely of the clover, and becoming so completely a piece of the stack itself, that were it not for the flight of the bird from the spot, it would have run no risk of detection. 
I have endeavoured as much as possible to make the place where I am residing (a portion of the old Oatlands park) attractive to every species of bird; and, much to my delight, have met with the especial approbation of Kitty Wren, which, though neither brilliant in colour nor yet in song, is one of a trio which are almost household birds, and help us by their cheerful presence through the dreary winter months. I have planted a number of junipers, and there is scarcely one without a nest, which is so incorporated with the shrub, that I have sometimes had much difficulty in finding the hole of entrance, fearful lest by moving the branches for the purpose, I might disarrange the nest.

No bird is so jealous of the discovery of its nest as the Wren. Amongst a great number of nests which I have found in the progress of building, I have never known one proceeded with after having been once discovered and touched, it being quite impossible to thrust the finger into the tiny hole of entrance without disarranging the neatness and beautiful symmetry of its form. This I have always found to cause its abandonment by the owner, and may readily account for the number of unfinished nests, which we used at school to call "cocks" nests," supposing that they were built by the male bird for its own particular abode.

When incubation is proceeded with, and the eggs have been sat upon for some time, the Wren, like all other birds, becomes much more attached to them, and is not then so easily driven to forsake them. The Rev. W. D. Fox has communicated to me a most remarkable instance of this attachment in one which would suffer its nest to be taken in the hand and examined, remaining the while quietly seated on its eggrs.

The Wren is a solitary, hardy little bird, and may be 
seen on some of our bleakest and most unsheltered districts. We saw it on some of the most sterile heaths of Shetland ; the only support for its nest being the bank of some mountain gully; its only shelter, the overhanging sod.

Notwithstanding the number of eggs which the Wren has been said to lay, I have never succeeded in finding more than eight, and rarely more than seven, in the same nest. They are usually less spotted than the Figure, and are not unfrequently quite white.

Ornithologists differ as to the inside of the Wren's nest; some maintain that it is thickly lined with feathers, whilst others deny that it has any in its composition. I have found it both with and without such lining, but think that it is most frequently finished with a few feather's. 


\title{
NUTHATCH.
}

\author{
SitTA EUROPÆA.
}

PLATE LXII. FIG. IV.

The Nuthatch, like the woodpeckers, breeds in holes of trees, the entrance to which is admirably protected and contracted by a plaster of clay, till it is just sufficiently large to allow the ingress of the bird. This entrance it defends against its enemies with the greatest courage; making a hissing noise, like the blue titmouse, when attacked. The nest, when there is anything between the eggs and the bare wood, consists of a few dry leaves, or bits of bark.

The Rev. A. C. Smith, of Yatesbury rectory, has sent me the following interesting description of the nest of a Nuthatch now in his possession, which was taken from the hole in a wall where a brick had been omitted, which hole the same birds had inhabited for many years. He says: "The birds plastered up with a thick wall of clay and small gravel stones this large aperture, only leaving one small orifice, by which they entered their house. One summer when the young birds were departed, I cut away with a knife this clay wall, and fitted it into a box, and so carried off the whole nest, which I now have. The nest itself was a deep bed of pieces of the inner bark of the Scotch fir-tree. I should think the quantity accumulated there must have been more than would fill 
a pint cup. It is astonishing how soft, and warm, and clean, this simple nest seems. I have it now, and it surprises all who see it. The hole by which the Nuthatches entered was peculiarly. small. I could scarcely get one finger in through it."

I should have had difficulty in understanding how a nest lined with the bark of a tree could be, as Mr. Smith describes it, "soft and warm," if he had not kindly sent me a portion of it, which is thinner than the paper on which I write; tough, and as pliable as the leaves with which other birds line their nests. I have tried in vain to detach from the tree pieces of bark as fine. The eggs are from five to seven in number, and in some of their varieties very much resemble those of the greater titmouse; others are marked with large blotches of red and grey, and are sometimes of an oval form, much blunted at the smaller end, like the figure of the plate. 
INSESSORES.

CERTHIA DAE.

SCANSORES.

\section{HOOPOE.}

\section{UPUPA EPOPS.}

PLATE LXIII. FIG. III.

Montagu mentions an unfinished nest of the Hoopoe, which was found in Hampshire; Mr. Blythe says that a pair frequented a garden in the neighbourhood of Tooting, Surrey, in the summer of 1833 ; and Mr. Jesse says that, some years ago, a pair of Hoopoes built their nest and hatched their young in a tree close to the house at Parkend, near Chichester. The best account of the summer habits of the Hoopoe is by Mr. E. H. Greenhow, of Tynemouth, which I have transcribed from the seventh volume of "Loudon's Magazine." - "On the Bordeaux side of the Garonne, and near the city, are large spaces of marshy ground, intersected by broad ditches and creeks, terminating in the river; where, from the advantage derived from the water, many poplars and willows are planted for the sake of the twigs, which are much used for tying vines. These trees being topped at about ten or twelve feet from the ground, so as to induce them to sprout much, become very thick; and, in the course of a few years, gradually decaying at the centre, are attacked by numerous tribes of insects. In these retired places, which are frequented only by a few cowherds and country people, the Hoopoe, which is a very shy bird, may be frequently observed examining the rotton wond, and fecding on the insects with 
which it abounds. The Hoopoe flies low and seldom, unless when disturbed, its food being so abundant as to require little search. It remains the whole year, and breeds in a hollow willow about the end of May, laying two eggs. The young come out in June." 

LXIII
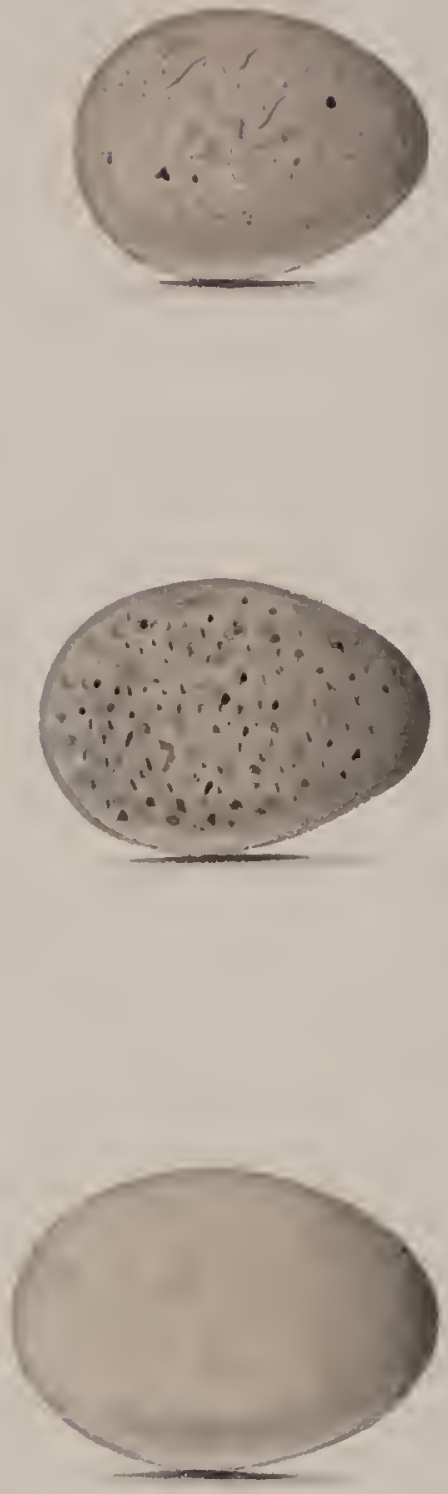


\section{CUCKOO}

\section{Cuculus canorus.}

PLATE LXIII. FIGS. I. AND IT.

So much is already known of the singular, and apparently unnatural, way in which the Cuckoo deserts its egg after laying it in the nest, and leaving it to the care of another and a strange bird, that I have not thought it necessary to repeat the often-quoted and interesting observations of the late Dr. Jenner; neither have I any original ones of my own to offer. It would, however, have afforded me much pleasure, could I have thrown any light on these interesting points with regard to the economy of this bird,- -what number of eggs it lays in one season, and whether or not it ever carries its egg, after having laid it, to the nest of another bird. Mr. Williamson, of Scarborough, informs me that he has found the egg of the Cuckoo in the nest of the rock-lark, close under the projecting shelf of a rock, and in a situation where he considers it impossible for the Cuckoo to have deposited it in any other way. La Vaillant, in his "Travels in Africa," mentions having in many instances shot a species of Cuckoo in the act of thus transporting its own egg in its mouth.

The egg's of the Cuckoo are found in the nests of several of our small birds. Of these, Mr. Yarrell enumerates thirtecn species, to which I have to add the name 
of the grasshopper warbler. The egg has been found also in the nests of some of the larger species,-the thrush, the blackbird, and the red-backed shrike. The Cuckoo seems, however, instinctively to prefer those, the eggs of which most nearly resemble its own. Amongst these are the larks, pipits, and the pied wagtail, to the eggs of which some light varieties of those of the Cuckoo bear considerable resemblance. It most frequently, however, makes choice of the nest of the titlark, which is common on those open heaths, the favorite resort of both. The egg, which is remarkable for its small size, is thus, together with its colour, admirably fitted for the deception which it is intended to practise. Though very similar in some instances to those of the skylark, there is a character about it peculiar to itself, by which it may be readily known. It is oval, and wider in proportion to its length; it is also usually marked with minute black dots. As I have stated above, there are light-coloured varieties, a good deal like the eggrs of the pied wastail. 


\section{ROLLER.}

\section{Coracias garrula.}

\section{PLATE LXIV. FIG. JII.}

THE RoLLel is one of those few occasional visitants of the British Islands, the brilliancy of whose plumage seems almost to tell us that it has but little right to a place in our catalogue.

The few instances of its occurence with us have been chiefly in the north of Britain. It is met with in the forests of Germany, and is not unfrequent in other parts of Europe.

It is said to breed in the holes of decayed trees; and in those districts where trees are scarce, to make its nest, like the bee-eater and the kingfisher, in a bank of earth, which appears to be its more natural position, if we may judge from the appearance of the egg. It lays from four to seven eggs, which bear a very close resemblance to those of the bee-eater and the kingfisher,--figured in the same plate,--in the roundness of their contour and the glossy varnished appearance of the shell. 


\section{BEE-EATER.}

\section{Merops ApIASTER.}

The Bee-eater is, like the last described species, an occasional, and but a rare visitor of this country. It breeds in various parts of the Continent, making its nest in the sandy banks of rivers, in manner much like the kingfisher, and lays from five to seven eggs. Montagu says that Bee-eaters abound in the south of Russia, especially by the rivers Don and Wolga, in the banks of which they build their nests, perforating holes to the depth of half a foot, or more, for that purpose.

The egg from which the accompanying drawing is taken is in the collection of Mr. Yarrell, and was given him by Baron Laugier, who told him that it was taken out of a hole perforated four feet deep in the bank of a river. 

IXIY
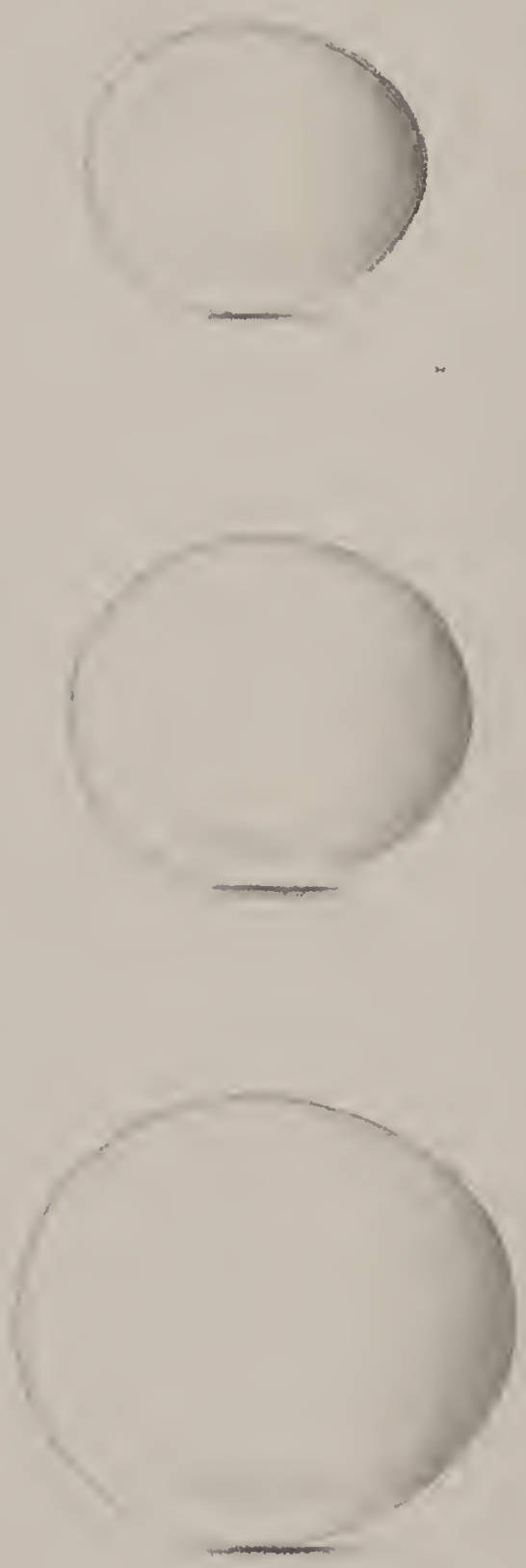


\title{
KINGFISHER.
}

\author{
AlCedo ISPIDA.
}

PLATE LXIV. FIG. T.

THIs splendid bird breeds sparingly in the sand-banks of many of our rivers, sometimes, as well, in the banks of a quarry, in a hole at the depth of two or three feet, in which it lays six or seven eggs; sometimes upon a collection of small fish-bones, but, I think, more commonly upon the bare sand.

From the many marvellous and exaggerated accounts given of the nest of this bird, Colonel Montagu was induced to pay particular attention to its habits, and gives the following very accurate and interesting particulars, perfectly agreeing with my own observations. "The hole chosen to breed in is always ascending; at the end is scooped a hollow, at the bottom of which is a quantity of small fish-bones, nearly half an inch thick, mixed in with the earth. This is, undoubtedly, the castings of the parent birds, and not the young, for we have found it even before they have eggrs. The hole in which they breed is by no means fouled by the castings ; but, before the young are able to fly, it becomes extremely foetid by the fres of the brood, which is of a watery nature, and cannot be carried away by the parent birds, as is common with most of the smaller species: in defect of which, instinct has taught them to have the entrance to their 
habitation ascending, by which means the filthy matter runs off, and may frequently be seen on the outside."

Mr. Wolley tells me that the Kingfisher always enters its nest by making a direct shoot into its hole from a bough opposite to it, and, generally, on the other side of the water; it usually forms the hole for itself, and, should this be destroyed, will commence another within a few inches of it.

In the summer of last year, as some men were digging the foundation for a house in a wild portion of Oatlands park, and at a considerable distance from any water, they discovered the nest and eggs of a Kingfisher, which was built in the gravelly side of a hole from which the roots of a tree had been extracted.

The Rev. A. C. Smith informs me, that at his father's residence in the neighbourhood of Devizes, where there is scarcely any running water, a pair of Kingfishers "chose as their resting-place the bank of a pond in a cow-yard (in which yard stood about forty cows daily), and within twenty yards of a farmhouse, pigsties, and all the noise and bustle of a regular farm, and here they reared their young." 
INSESSORES.

FISSIROSTRES.

HIRUNDINIDA.

\section{SWALLOW.}

\section{Hirundo RUSTICA.}

PLATE LXV. FIGS, III. AND IV.

There are but few of the minor pleasures of life, to be derived from the glorious works with which a kind Providence has on all sides surrounded us, that I could not more readily consent to part with than the visit of our cheerful friends the Swallows. They spend a part of their lifelong summer round about our dwellings; and, should we go beyond our doors, they are still, like some good spirit, hovering o'er us. If the day prove bright and beautiful, they may be seen, almost beyond the reach of vision, far away in the deep-blue sky. Should the weather be dull and cloudy, and we stray forth into the green fields, we shall there find them near us; at one moment rapidly crossing our path, and in the next coming to meet us. If we wander down the banks of the river, and are fond of fishing, they will be with us the day long, coursing up and down the stream, and ever and anon "dipping their dappled wings," and, in the beautiful language of Wilson, "sweeping over our fields and rivers, and through our very streets, from morning till night, that the light of heaven itself, the sky, the trees, or any other common objects of Nature, are not better known than the Swallows."

There are but few so indifferent or unobserving as not to greet them with pleasure, on their return to us after a 
long and gloomy winter. The arrival of the first Swallow is hailed by all: it brings with it a thousand recollections of "sunny skies and cloudless weather," of days spent in the open fields, and of pic-nics in the deep green woods. On its coming, the trees have been wont to put forth their brightest foliage, the meadows have been strewn with flowers, the butterfly and the beetle have once more come forth from their winter's sleep, and "the woods its welcome sing."

I never see these dear birds gathering in the autumn, ere they take their departure for sunnier skies, or watch the last lingering few which the bright days of October have induced to tarry behind the rest, without regret that they are going to leave us-without feeling that I am about to lose my friends, the companions of all my solitary summer rambles, or without wishing a heartfelt blessing on their distant way.

Their lives are not only altogether harmless, but every hour that they live is spent in doing us good, and to an extent of which we can have but little conception; and brutal and roid of feeling, and ungrateful to that Great Being who made them for our good, must that man be, who can, in mere wantonness, destroy and carelessly cast from him, to rot upon the ground, the beautiful form which, but for his thoughtlessness, had been soaring above his head full of life and enjoyment? Would that some superstitious dread predicted evil to their destroyers; or that some reverential feeling, or gratitude for their services, would protect them from evil, as the ibis of old, the stork of Holland, the purple martin of the United States, or even the hero of nursery tales, our own familiar robin-red-breast!

It is now well known that the Swallows will return to the same place, and rear their young ones in the same 
nest, for many years in succession. A pair had, for several years, built their nest in the wash-house adjoining a cottage near York, finding their way in through a broken pane, passing in and out undaunted even on the washing-day. 'The rigour of a severe winter had made it necessary to glaze the broken window in the washhouse; and on the following summer, when the Swallows came as usual, and found their ingress prevented, they seated themselves upon the clothes-lines, and in repeated chattering expressed their disappointment. The pane was, however, speedily removed; for the old lady to whom the place belongs is a great lover of their company, and likes well to hear their cheerful twittering.

The Swallow makes its nest in our chimneys, in barns, out-houses, and sheds, fixing it upon the cross-beams and against those that support the roof; occasionally, also, in the shaft of a deserted coal-pit. I have seen the nest against a door, which was daily opened many times, and yet the poor bird continued to sit till the nest was shaken down and destroyed, and even built a second time, and shared the same fate. Mr. Yarrell gives a figure of a nest of this species, which was built upon the bough of a sycamore-tree, hanging low over a pond.

The nest of the Swallow is similar to that of the house martin, with the exception of its being open at the top; it is made of the same materials, mud and clay, rendered more adhesive by mixing with it small pieces of straw; it is lined with dry grass and feathers, and contains four or five eggs, always readily known from those of any other species of bird.

The variety which I have drawn at figure 4, was sent me by Mr. J. W. Johnston, of Dumfries, under the belief that it is an egg of the house-martin. As Mr. Johnston has no positive evidence to confirm this belief, I have 
taken the liberty to differ from him, and to figure it as a curious variety of the egg of the Swallow, fully persuaded myself, that eggs, which are naturally and characteristically of a pure white, are unchangeably so, and this I believe to be a law in the colouring of eggs. 
INSESSORES.

FISSIROSTRES.

HIRUNDINIDE.

\section{MARTIN.}

\section{Hirundo URBICA.}

PLATE LXV. FIG. II.

How delightful is it, at the earliest dawn of daylight, when first awakening from sleep, to hear the soft, cheerful twitter of this gay bird, as it is forming its clay-built shed at the corner of our windows, or returning with food for its young ones; and how barbarous the custom, and I deeply regret to say that I have myself been guilty, of shooting these inoffensive useful birds! Ought we not rather to receive them as the people of the United States do the purple martins, which are everywhere considered by them as their friends and benefactors, and boxes prepared and hung against their houses purposely for the reception of their nests? "I never met with more than one man," says Wilson, "who disliked the martins, and this was a penurious close-fisted German, who hated them because they ate his bees."

The martins are, I fear, and I grieve to think it, yearly becoming less numerous in this country. In many of our villages, where they were very abundant, and their nests were clustered together under almost every "low-roofed cottage-ridge," they are now never seen. In Germany, on the contrary, where they are unmolested, they so abound, that their nests are crowded together in dozens under the lowliest roofs. 
This cannot arise altogether from the infamous persecution which they meet with from a set of idle vagabonds, calling themselves sportsmen, nor yet from any change in our climate, because they abound in latitudes further north. Mr. Wolley, writing from Muonioniska, in Swedish Lapland, says :- "The House Martin is very abundant here. Round the court-yard of a peasant's house, I counted a hundred and sixty nests still remaining, although all those upon one side had lately fallen down. It is a general favourite; and the people everywhere nail up narrow planks upon the walls to support the nests. There are often three or four rows, one above another, the boards being placed at such distance apart that there is just room for the nests between."

Amongst the many natural beauties which surround the residence of Chatsworth, there was not one which pleased me so much as a large colony of Martins that have established themselves at one end of the building. Here the good taste of the owner has allowed them to remain unmolested; and, many hundreds together, their evolutions add a most stirring cheerfulness to the scene. The Martin builds its nest, as every one is aware, under the eaves of our houses and at the corner of our windows; and, although apparently giving a preference to the walls of man's dwelling-place, against which it erects its own claybuilt habitation, there are several places around our coast where numbers of Martins breed together, building their nests against the surface of the cliffs. In the north of Norway there is an island rock, known by the name of Torghattan, remarkable for a broad and lofty tunnel, which passes through it from sea to sea. Whilst standing midway amidst the heaps of rubbish which had fallen from its top, and admiring as well the rastness of this grand natural archway, as the singularly pleasing views 
through each of its mouths, seaward and inshore, we noticed some hundreds of Martins' nests, plastered against the irregularities of its roof, from which the owners were passing in and out in quick succession.

The nest of the Martin is composed of mud, rendered more adhesive by the mixture of small bits of straw; and, as observed by White, it is provident enough not to advance it too fast, but, by building only in the morning; gives it sufficient time to harden, lest, while soft, its own weight pull it down. Mr. Couch says, "I have known them neglect a fine morning, and carry on the work through the afternoon, from no other apparent reason than the facility of procuring mortar at that period from a small distance, in a place which, in the morning, was covered with the tide." The lining of the nest is of fine grass and feathers. The egrgs four or five in number. 


\section{SAND MARTIN.}

\section{HIRUNdo RIPARIA.}

PLATE LIV. FIG. I.

WE see less of the Sand Martin than of any of the swallow tribe. Whilst the other species spend the greater part of the time they are with us round about our dwellings, building their nests under the same roof ourselves inhabit, it retires to the more peaceful quiet of the country, and is seldom seen, unless we follow it to, its favourite haunt, the margin of a river. There, if the banks are elevated for a few feet above the influence of the water, and of a sufficiently porous soil, numbers of round holes may be seen, about the size of those perforated by the water-vole, which these birds have made with much toil and labour, as a place of reception for their nests. Should you examine them, you may observe that, unless the soil is soft and sandy, many of them remain unfinished, the hardness of the substance having, most probably, driven the birds to seek a softer soil ; and yet, at some of their breeding-places on the sea-coast, I have found the stratum so hard as to cause me some trouble sufficiently to enlarge the holes, not only to the detriment of my nails and fingers, but to the destruction of a stick-knife, without the assistance of which my wish to obtain the eggs must have remained ungratified. How, then, can we sufficiently admire the perseverance, and wonder at the 

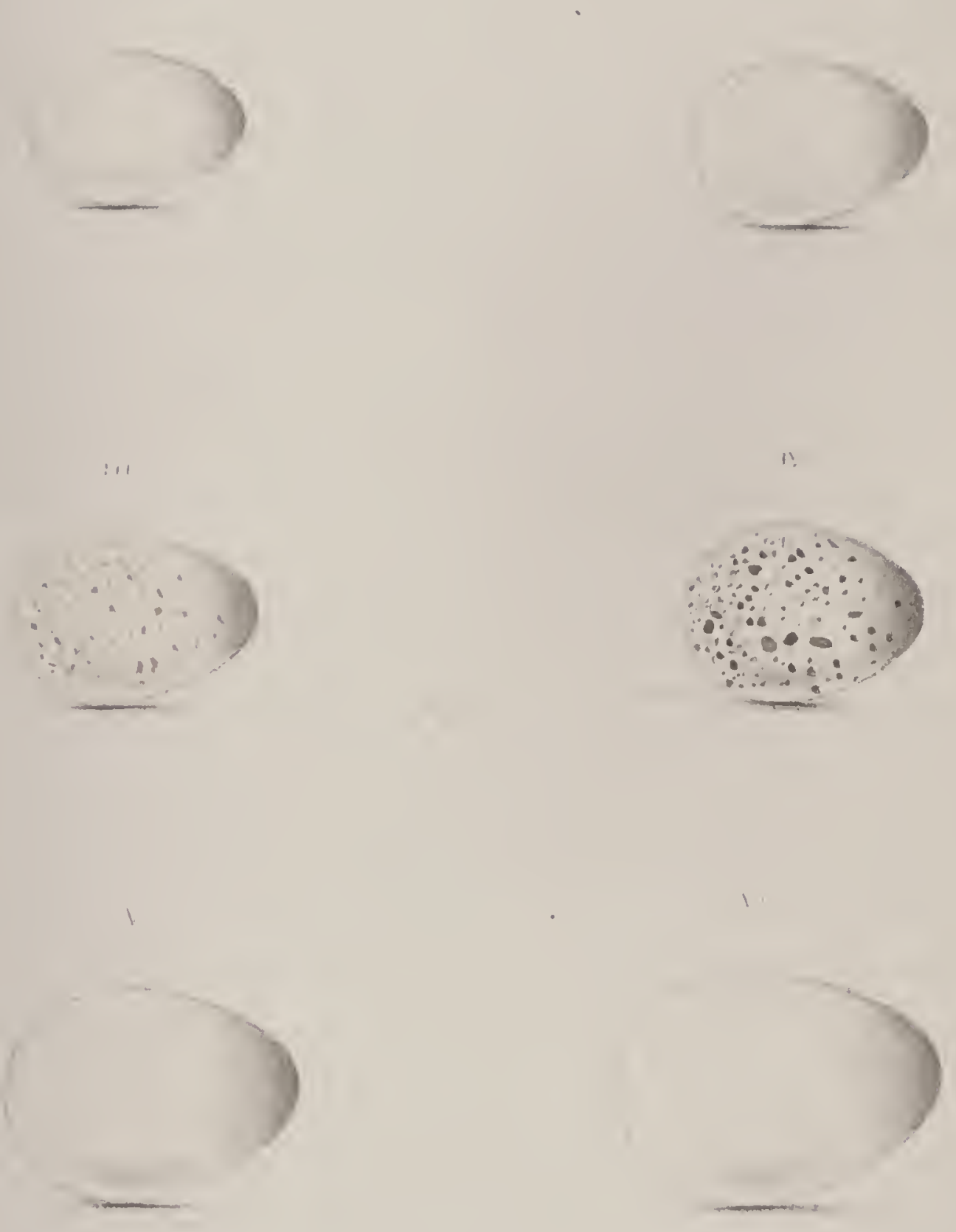

power, which enables these little birds to overcome such difficulties?

Those holes which are completed, if no meddling hand has intruded to widen the orifice, are not sufficiently large to admit the arm, and from eight to eighteen inches deep. The doorway, which they seem most anxious to protect, is the narrowest part of the hole, which becomes wider towards the nest. In places where they have been yearly subject to disturbance, failing to touch the eggs at arm's length, I have only succeeded in doing so by the addition of a hooked stick, which reached them at the depth of from five to six feet. The Martins usually make their holes near the top of the bank, being evidently most in fear of enemies from below. I once saw a colony in great consternation, without being able for some time to discover the cause of alar'm, when I observed a weasel, which made its entrée from above, passing from one hole to another, and no doubt making dire havoc either amongst the old birds or their young ones.

Besides the banks of rivers, which are their favourite haunts, there are many parts of the sea-coast to which the Sand Martins resort to breed. Their nests may be also occasionally met with in the banks of quarries and deserted sand-pits.

The outside of the nest is loose and flat, and of dry grass, profusely lined with the feather's of ducks and geese, more especially those from the breasts of these birds, which, in their natural curve, give the roundness of the interior of the nest. Mr. Wolley informs me that at Burlington, in Yorkshire, the Sand Martins make their nests of sea-weed. The eggs, which are four or five, and rarely six in number, are, whilst the yoke is in them, beautifully tinged with pink.

Whilst watching the evolutions of some Norwegian 
soldiers, we were surprised to see that a colony of Sand Martins had scooped out their holes in a sandy bank which formed the boundary of the parade, and though close to the walls of the city of Drontheim, and not more than arm's reach from the ground, were enjoying undisturbed and quiet possession of their homes. 
INSESSORES.

FISSIROSTRES.

IIIRUNDINIDA.

\section{SWIFT,}

BLACK MARTIN, SCREECH, DEVILING.

\section{Cypselus murarius.}

PLATE LXY. FIG V.

THE SwIFT usually brings forth its young ones in holes of old ruins, towers, and steeples; sometimes under the tiles of churches and houses, and in lime-kilns. White says, "In this village (Selbourne) some pairs frequent the lowest and meanest cottages;" and further adds, "we remember but one instance where they breed out of buildings, and that is in the sides of a deep chalkpit." To this I may add, that I have seen them breeding in various places in the cliffs of the sea-coast.

Professor Nilson says that, in Sweden the Swift breeds in hollow trees, a statement which is confirmed by $\mathrm{Mr}$. Wolley. A correspondent of "Loudon's Magazine" also states that, observing a number of these hirds at a distance of thirty miles from any place where it was likely that they should breed, upon making inquiry, he discovered that they were occupying for that purpose the holes in trees perforated by the woodpecker.

For the most part, I believe the Swift deposits its eggs either upon the bare stone or mortar, or upon the remains of a sparrow's nest; sometimes it builds one for itself. This is, however, of very little substance and 
slight materials, being composed of a few straws, lined with feathers, and strongly cemented together with some glutinous substance. For several of these nests I am indebted to Mr. Salmon. The eggs of the Swift vary from two to four in number. 
INSESSORES.

FISSIROSTRES.

HIRUNDINIDA.

\section{ALPINE SWIFT.}

Cypselus alpinus.

PLATE LXV. FIG. VI.

No wonder that the Alpine Swift should sometimes visit our shores, since it is common throughout a great part of the southern continent of Europe, and gifted with a speed of wing which would set distance at defiance. Its flight is said to be even swifter than that of our well-known species. It is met with in some parts of France, Spain, Italy, and Switzerland. It breeds, like our own species, in high rocks, ruins, and in church steeples.

This Swift makes a nest, similar to the commoner species, of pieces of straw firmly cemented together by some glutinous matter, and lined with feathers, in which it lays from three to five eggs.

When seated on the promenade under the beautiful cathedral at Berne, enjoying the glorious view which it commands of the distant Alps, I have had the additional pleasure of watching these birds careering round the beautiful old steeple in which they breed; I have also seen them in numbers, passing in and out from the perpendicular rocks which form one side of the deep defile through which the road leads you on your way from the baths of Loeche to the Canton Vallais. 
FISSTROSTRES.

\section{NIGHTJAR,}

NIGHT HAWK, FERN OWL.

Caprinulgus europeus.

PLATE LXVI.

The Nightjar is most common in those open moorland tracts of country which immediately surround a more cultivated and woody district. In such situations it deposits its eggs, without any nest whatever, amongst heath, fern, and grass, or in a slight depression upon the bare ground, never far from the neighbourhood of woods or a woody district; its eggs may also frequently be found in open grassy spaces, and in drives occurring in the midst of large woods: they are two in number, and are amongst the most beautiful of our British birds' eggs; in shape they are peculiar, being almost of a perfect oval.

The American species of this genus, of which Wilson has given such interesting descriptions, all closely resemble ours in their mode of breeding. 


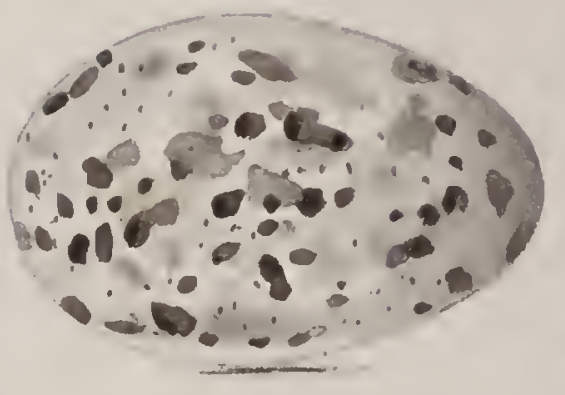




LXVII

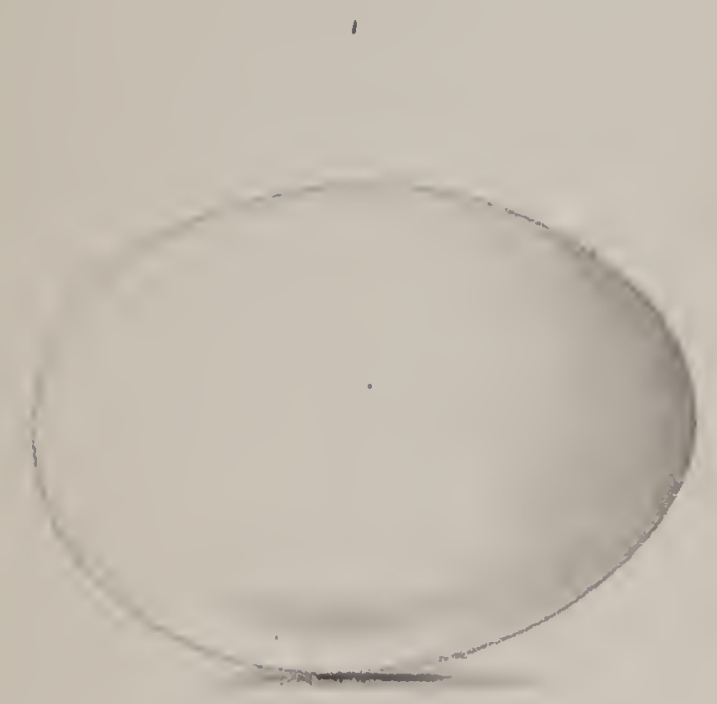

11

ii

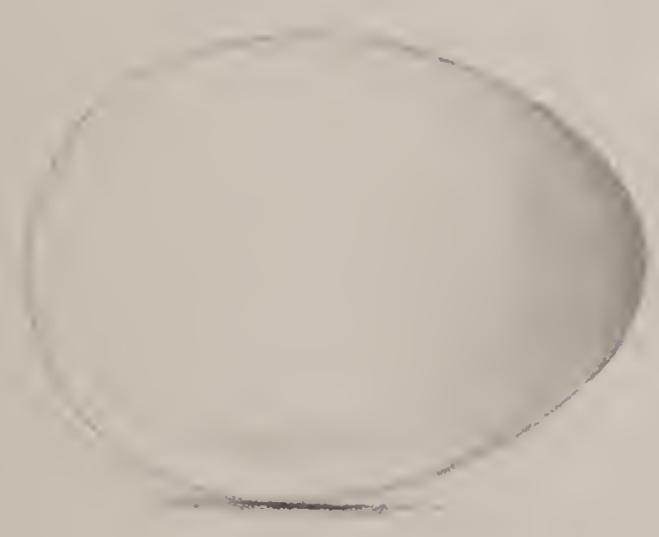

11

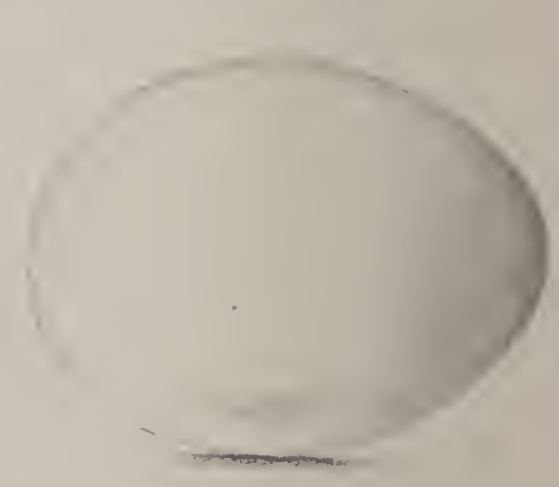


RING DOVE,

WOOD PIGEON, CUSHAT.

\section{Columba palumbus.}

PLATE LXVII. FIG. I.

The Wood Pigeon begins to build early in April, and is then to be met with breeding in almost every wood and plantation throughout the country; and though, in some instances, it retains much of that shyness which characterized it during the winter, and does not generally allow you to come near it on the nest, it is sometimes much more familiar, building its nest in pleasure-grounds in the immediate vicinity of the house. At Seaton Burn, near Newcastle, these welcome and delightful visitors may be seen from the windows of the house, whilst sitting on their eggs; and, in one instance, I observed a nest, which was placed in a single thorn-bush within a few yards of the gardener's cottage, where children were playing round it all day long; and, what is still more unusual, a pair reared their young ones during the last summer, in ivy against the house, close under one of the bed-room windows.

The Ring Dove builds a nest so slight, that it is a matter of surprise that it is not blown out of the tree, or the eggs out of it. It is formed of dry sticks crossing each other, and is without any cement or lining whatever; it is a level platform, with little or no concavity, and has very 
little the appearance of a bird's nest; it is so loosely put together and so slight, that the eggs may, in many instances, be seen through from below. Mr. J. H. Tuke informs me, that he has frequently found the nest of this species upon the deserted nest of a squirrel.

The Ring Dove seems to prefer the branches of the oak and fir-tree, as being more horizontal and better suited to the flatness of its nest; it is found, also, in thorns, and in ivy growing against trees. It has two or three broods in the year, and lays invariably two eggrs, of a glossy white, and, for the most part, of a perfect oval. I have known young ones in the nest as late as the middle of September.

Mr. Hancock has, in several instances, found the nests and eggs of this species in Scotland, upon the ground amongst the heather at the base of the Scotch fir, and sheltered by its overhanging branches, and in the near neighbourhood of an extensive forest. 


\section{STOCK DOVE.}

\section{Columba enas.}

PLATE LXVII. FIG. II.

The STOck Dove, though rarely met with in the north of England, breeds in some of the southern counties: it is not uncommon in Epping Forest, where, under the kind guidance of Mr. H. Doubleday, I have taken its eggs from the pollard hornbeam-trees, in which it breeds.

In Norfolk, Mr. Salmon says that the Stock Dove occupies the deserted rabbit burrows upon warrens, placing its eggs about a yard from the entrance of the hole, usually upon the bare sand, but sometimes making use of a small quantity of dry roots, barely sufficient to keep the eggs from the ground, and that it also lays its eggs under those thick furze-bushes which are impervious to the rain: both very curious habitats for a bird like this. The Stock Dove breeds early in April, and, like the rest of the genus, lays its two white eggs, which, Mr. Wolley remarks, are more tinted with cream-colour than the other species. 
IN habits, this species differs considerably from the rest of the genus: whilst they chiefly frequent woods, roosting upon and making their nests in trees, the Rock Dove inhabits the cliffs upon our sea-coast, in which it breeds, laying its eggs in holes and fissures of the rocks. Mr. Low, in his "Fauna Orcadensis," says, that "they are found round all the rocks of the mainland and isles, where they build in the caves, but retire further in than the hawks, gulls, or most other sea-birds, except some of the petrels."

In the Shetland Islands they abound, breeding in the numerous spacious caverns into which the sea constantly rushes; they have every appearance of being tame, and are so easily approached within gun-shot, that, until assured of the contrary, we took them for the inmates of some neighbouring dovecote. They approach quite close to the huts of the fishermen, to feed over the small cultivated patches of corn-land; and, I have little doubt, might, if encouraged and fed, be readily domesticated.

Mr. G. C. Atkinson found several of the eggs on the Isle of Harris, at the furthest extremity of caves in fissures in the rocks. The eggs are two in number, and usually somewhat less of a regular oval than those of the two species before described. 


\title{
TURTLE DOVE.
}

\author{
Columba turtur.
}

PLATE LXVII. FIG. IV.

LIKE the stock dove, this species breeds only towards the south of England; being scarcely ever met with in the north, and then only in winter. I have seen it in the counties of Norfolk, Suffolk, and Surrey, during the breeding season. It builds its nest in the same manner as the ring dove, in woods and plantations, but frequently in a less elevated position, and sometimes in a thornhedge: it is of sticks placed crosswise, and forming a very loosely-constructed platform; upon this it lays its two white eggs, which are more pointed than those of the other species. 


\section{PHEASANT.}

\section{Phasianus colchicus.}

PLATE LXVIII.

The Pheasant is too well known to need much description. It breeds throughout the country in May and June, and lays its eggs upon the ground in woods and plantations amongst the underwood; under the cut branches of trees, and in the long grass; sometimes also in hedge-rows, and occasionally in the open fields: they are from ten to fourteen in number, and nearly round; they are most commonly of the colour of the plate, but frequently much lighter. From the near approach of the Pheasant to domestication, the eggs are subject to the same strange and whimsical forms seen in those of our common fowls. I possess some very remarkable deformities of this kind, obligingly sent me by the Hon. Mrs. Liddle; one in particular, which is cylindrical, about two inches and a half long, and an inch and a half in diameter. 
LXVIII

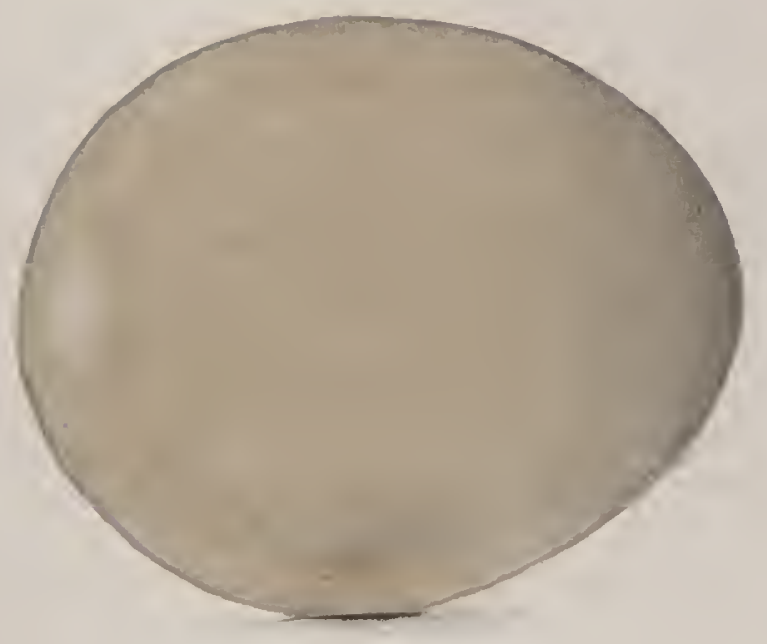



RASORES.

TETRAONIDA.

\section{WOOD GROUSE,}

COCK OF THE WOODS, CAPERCAILLIE.

PLATE LXIX. FIG. II.

THIs fine bird, which has been for some time extinct in our own country, breeds in the mountainous pine-forests of the north of Europe, in Norway, Sweden, and Russia. In Norway it is, however, in some seasons so rare-and the year of our visit was one of scarcity-that it was with the greatest difficulty that we could procure specimens of its eggs; and although wandering for many days through those parts which were far from human habitation, and where we were told it was abundant, we had, in two instances only, the satisfaction of seeing it alive. In these remote situations it lays its eggs under the shelter of a young spruce-fir-tree, in those parts of the forest which are clear of the large timber; they are from eight to twelve in number, and are deposited upon a small quantity of dry grass towards the end of June.

Though for many years extinct in Britain, several attempts have recently been made to re-establish the Capercaillie in this country, and, I trust, with some success. $\mathrm{Mr}$. Hancock has several eggs, laid in Scotland during the year 1853. The eggs of this and the following species have all the character of those of the turkey. 


\title{
BLACK GROUSE.
}

\author{
TETRAO TETRIX.
}

I'TANE LXIX. FIG. I.

In England, the Black Grouse is most abundant in the northern counties, and is generally diffused over most parts of Scotland. Many experiments have been made to introduce it into those districts, further south, where it was not naturally indigenous, but for the most part without success, although attempted in situations which appear in every way favourable, and similar to those in which they are naturally in great abundance.

In habits, this species differs considerably from the next. Whilst the red grouse inhabits the most desolate and the wildest heaths, the Black Grouse frequents the borders of cultivation, breeding either amongst the heath or in recently planted ground, and sometimes in the hedge-rows. It lays from eight to ten eggs, usually much less strongly spotted than the plate, and differing considerably according to the locality in which they are found. 

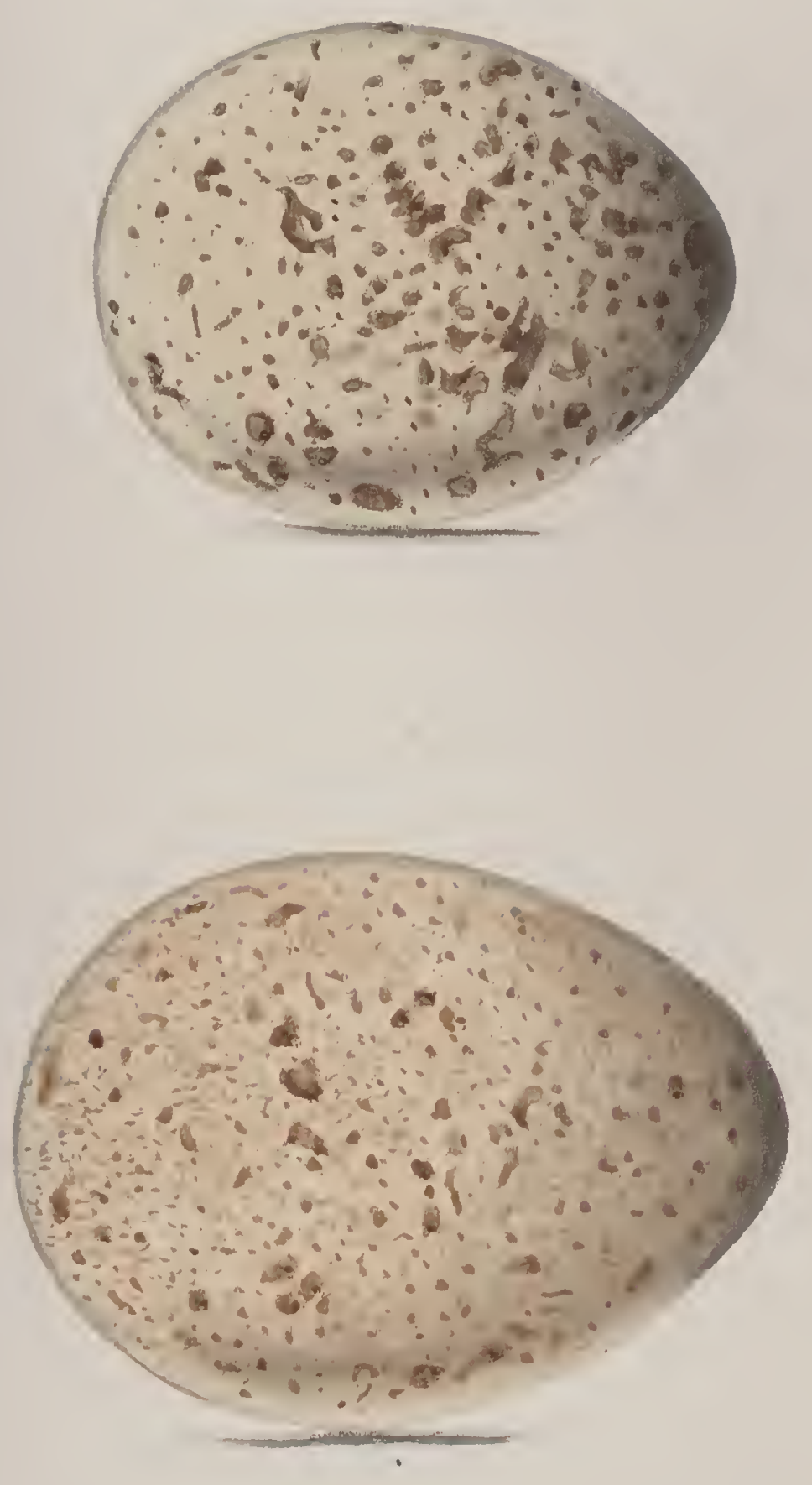



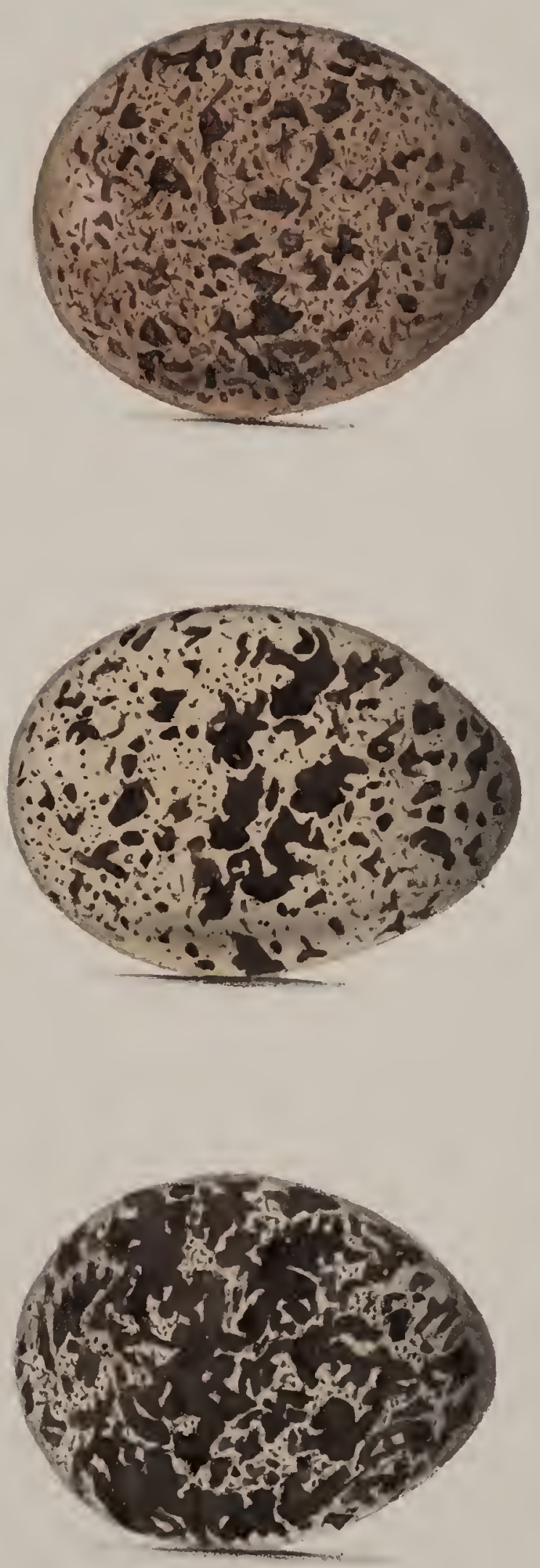
RASORES.

TETRAONIDE.

RED GROUSE.

Tetrao Scoticus.

PLATE LXX. FIGS, I. AND If

THE eggs of the Red Grouse, for depth and richness of colouring, are unrivalled by those of any other British bird, and are, in consequence, a beautiful ornament to our cabinets. The Red Grouse, which has hitherto been met with only in the British Islands, breeds on most of the high heathy moors of this country, especially those in the north of England and the Highlands of Scotland. It is abundant, also, on most of the Western Islands, and is met with sparingly in Orkney, but has never been found in Shetland, though at so short a distance. It begins to breed early in April, and makes its nest, when any, in a tuft of heather, gathering together a few pieces of heath and some dry grass. The eggs are from eight to twelve in number, and present many very beautiful and strongly contrasted varieties; eggs similar to both the figures of the plate are frequently found in the same nest. The third figure of the plate will represent well a variety of the eggs of this species. 


\section{PTARMIGAN.}

\section{Tetrao lagopus.}

PLATE LXX. FIG. III.

Although the Ptarmigan breeds in various parts of Scotland, the eggs are very difficult to obtain. Its breeding-places are those bare, stony spots which cover a portion of most of the higher mountain ridges, amongst which it finds secure retreat; its similarity to the ground in colour is so great, and its heedlessness of danger is such, for it will remain closely crouched till you approach within the shortest distance of it, that it thus eludes discovery.

The eggs, which are from eight to twelve in number, are deposited either upon the bare ground or upon a small portion of dry grass or heath; those that I have seen are precisely like some of the varieties of eggs of the red grouse.

The Ptarmigan, as well as several other species of grouse, are said to be very abundant in Norway during the breeding season; they were all, however, very scarce during the summer of our visit to that country: the only variegated grouse we met with was the $T$. Saliceti, the willow grouse; and, of this, two specimens only were all that rewarded our many wild rambles on those glorious snow-clad mountains, and these were so tame that we had difficulty in compelling them to fly. 

LXXI
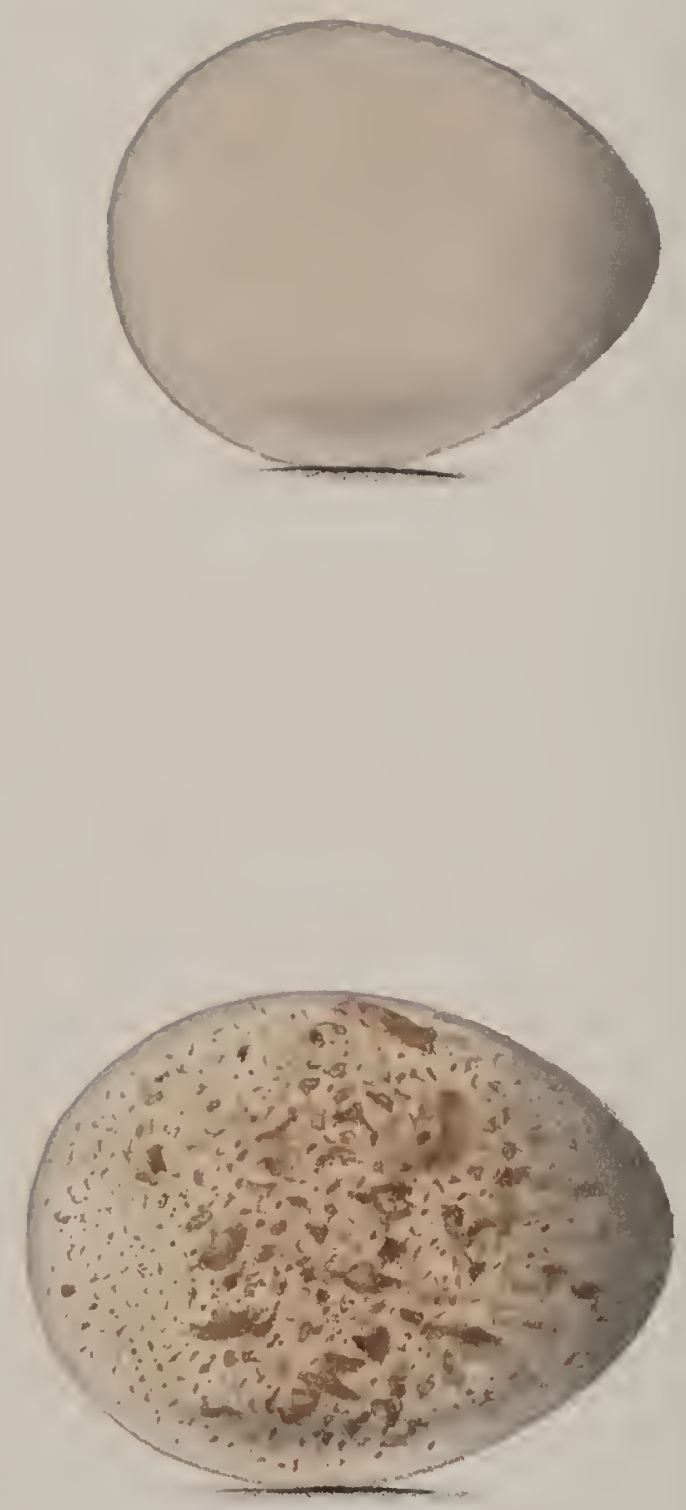
RASORES.

TETRAONIDAE.

\section{PARTRIDGE.}

\section{Perdix cinerea.}

PLATE LXXI. FIG. I.

The Partridge, though everywhere more or less frequent, is most numerous in the counties of Norfolk and Suffolk. It is usually met with amongst the crops of the cultivated land; but I have not unfrequently found a covey upon those heathy, uncultivated moors which border on vegetation; they are, in such places, wild and wary, and difficult to shoot.

The Partridge lays its eggs either upon the bare ground, or upon a few pieces of dry grass carelessly scraped together; they are deposited in open pastures, meadows, and corn-fields; in a tuft of grass, or under the shelter of furze or other brushwood; amongst newly planted trees, and at the bottom of a thorn-hedge.

The eggs are numerous; they are usually ten or twelve, but are said, in some instances, to equal eighteen or twenty in number; they differ, like those of the pheasant, many being considerably lighter than the plate. The assiduous perseverance of the Partridge during incubation is well known; numbers of instances might be given in illustration; none, perhaps, more striking than that mentioned by Montagu, of one which allowed itself and eggs to be deposited in a hat, and thus carried unresistingly into captivity, where it continued to sit them till the young ones were brought out. 


\section{RED-LEGGED PARTRIDGE,}

GUERNSEY PARTRIDGE, FRENCH PARTRIDGE.

Peridix RUfA.

PLATE LXXI. FIG. II.

The Red-Legaed Partridge is, like the pheasant, only a native of this country by adoption, and without its long claim of naturalization; it is, however, becoming so generally dispersed through some of the southern counties, that I have thought it right to give its egg a place in this work. In Oxfordshire, Mr. Daniel says that it is abundant, the Marquis of Hertford having introduced it by bringing over, from the Continent, many thousand eggs, which were reared under hens, and their produce turned at large. It is also abundant in the counties of Norfolk and Suffolk. Upon the estate of Sir Thomas Gooch, Bart., to whose kindness I owe the pleasure, I have seen several covies during a day's shooting. They are much wilder than the common partridge, and run for a considerable distance before they will take wing, keeping the dogs at a running point.

The Red-legged Partridge makes more of a nest than the common species, and raises it a little above the level of the ground; it is of dry grass mixed with a few feathers of the bird. The usual number of eggs is from ten to twelve. Mr. Salmon has several spotless eggs which 
I believe to be varieties of this species; he tells me that he has seen a nest containing eighteen eggs; and Temminck says that they lay from fifteen to eighteen eggs. Mr. Salmon says that, from the wilder nature of this bird, it seems to prefer the heathy districts, to those that are under cultivation; if this is the case, and it would thrive upon the extensive moors of the north of England, it would there form a beautiful additional tenant of the soil. 


\section{QUAIL. \\ COTURNix vUlgaris.}

PLATE LXXII.

The QUAIL is a rare bird in the north of England, a pair or two only occurring occasionally during the breeding-season; they are then, however, not likely to be disturbed, being concealed amongst the corn and long grass, and are probably more numerous than is supposed. They lay their eggs upon the ground, in meadows and cornfields, having first collected together a small quantity of dry grass; these vary much in number, being from six to fourteen, though most commonly about ten; they differ also greatly in colour and markings, as the plate will shew, there being many more equally striking varieties. The second figure is the egg most characteristic of the species.

The Quail must be very abundant in France; I have seen many of them in the fields when passing through the country by railway. 

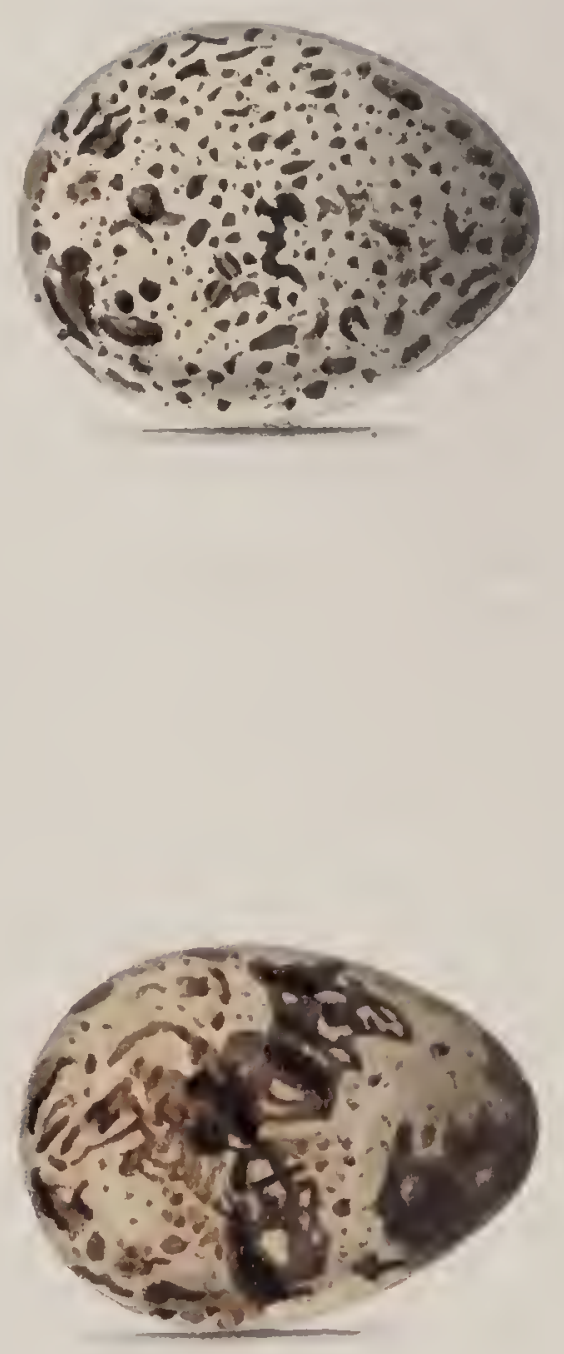

L XXIII
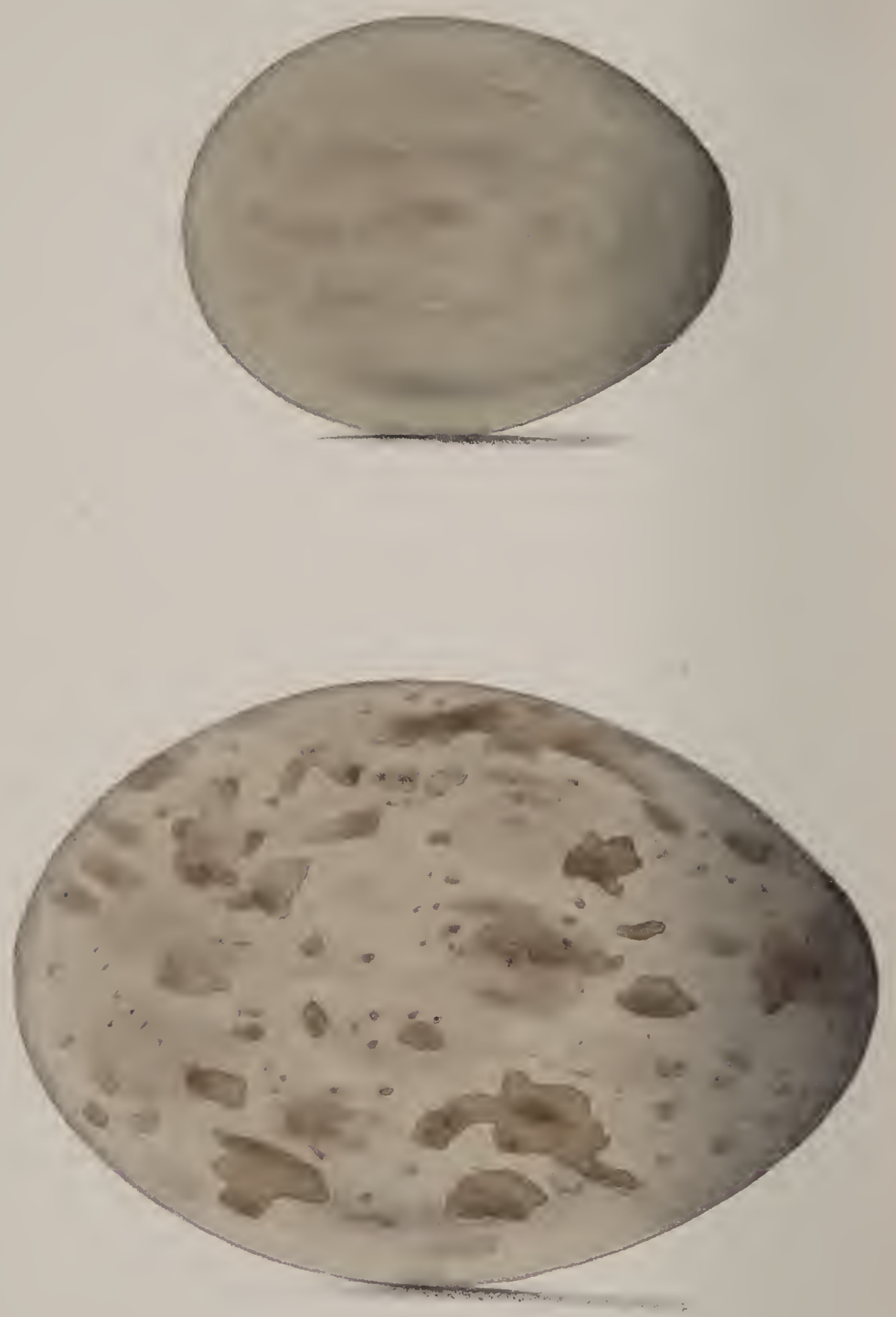


\title{
GREAT BUSTARD.
}

\author{
OTIS TARDA.
}

PLATE LXXIII. FIG. I.

THIs fine bird, which the gun or the spread of cultivation has either destroyed or driven from our shores, will soon be remembered only as once having existed in our land, gladdening with its presence the open wolds and downs of our country, and adding an interest to the bleak and sterile heath. The Bustard has existed, till within a few years, on those extensive sheep-walks, the wolds of Yorkshire, from whence I have seen their eggs, and in the earlier time of Montagu was to be met with on the plains of Salisbury. Mr. Spurgeon, of Lynn, to whom I was indebted for an English specimen of the egg of this bird, figured in the "British Oology," gave me the following information, during the publication of that work. He says, "I am much afraid that all the male birds are extinct in this kingdom, and, therefore a few years will end the species altogether. I have seen from fourteen to eighteen females in the various large fields in the west of Norfolk, called breaks; they are wild, and difficult to approach." The Bustard makes no nest, but lays its eggs, two in number, upon the bare ground. The egg which I have now figured is in the collection of Mr. Salmon, and was laid in this country. 
The Great Bustard will still occisionally find its way here, and would remain with us if allowed to do so. Mr. Hancock tells me that he saw one during the present spring (1854), which was shot in a turnip field, near Brampton, in Cumberland.

The increasing taste for ornithology, and the mania to possess a British-killed specimen of any rare bird, has made it hopeless that any such bird, especially if of large size, should long escape with life after having unluckily landed on our shores. 
RASORES.

STRUTHIONIDE.

\title{
LITTLE BUSTARD.
}

\author{
OTIS TETRAX.
}

PLATE LXXII. FIG. II.

LIKE the closely-allied species, the Little Bustard lays its eggs upon the bare ground. They are said to be from three to five in number, and have been described as "of a clear, shining, grass-green colour, without spot or stain." Those eggs which I have seen are all, more or less, suffused with colour. Any one who had previously seen the eggs of the great bustard, would look for a similar character in those of the present species; and he would be pleased in observing the resemblance which they bear to each other, distinct as they are from those of all other birds. 


\section{NORFOLK PLOVER,}

THICK-KNEED-BUSTARD, STONE-CURLEW.

\section{CEDICNEMUS CREPITANS.}

PLATE LXXIV.

The Norfolk Plover, as its name would lead us to expect, is abundant in that county, as also in the adjoining one of Suffolk. It breeds upon those extensive sandy flats which chiefly border upon the sea-coast; its nest is nothing more than a slight cavity scratched upon the surface of the ground; its eggs are invariably two in number; those figured in the plate are selected from a large and beautiful series, for which, with the information given above, I am indebted to Mr. Salmon.

The figures may be considered as two extremes, between which there is a regular gradation of varieties, from the closely-spotted surface of the first figure, the markings of which have but one shade of colour throughout, to the more distant, deep, and many-tinted spots of fig. 2; these are both of the usual ground-colour. There are, however, other varieties, the surface of which is of a dirty yellow, with the spots upon it muddy and ill-defined. A variety in the collection of Mr. Salmon has the groundcolour white, slightly marked with lilac and rufous spots, like eggs of the Sandwich tern. 

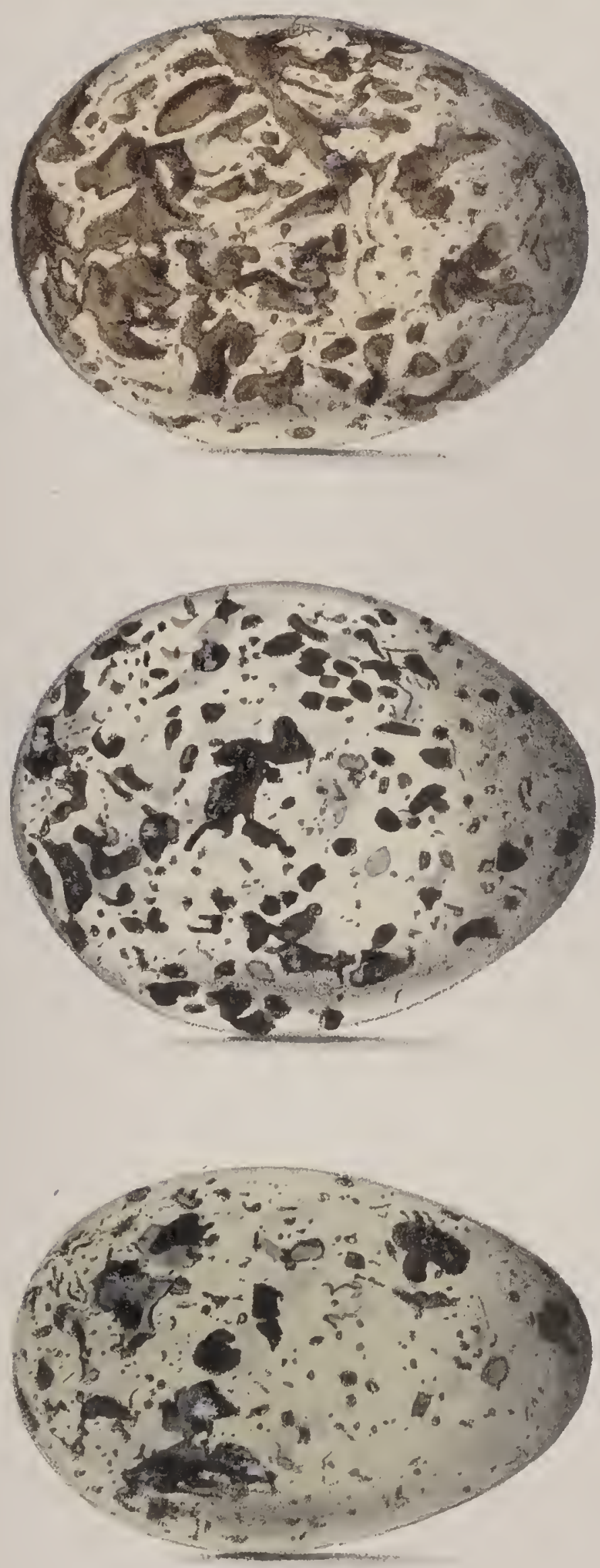

Since the preceding page was printed $I$ have been induced to give a third figure to represent a very unusual variety, and regret that the scope of the work will not allow me to give further illustrations.

Mr. Newton, who lives in the head-quarters of these birds, has most kindly sent me a beautiful series of several dozen of their eggs; some mapped over the entire surface, as if covered with a piece of the finest seaweed; others, which might pass for eggs of a falcon both in shape and colour, one especially, which has all the spots at the smaller end, a variety common to eggs of the sparrow-hawk; many of them, like Mr. Salmon's egg mentioned above, much resembling eggs of the Sandwich tern.

Mr. Newton says, that "the Norfolk Plover is remarkable for its attachment to its breeding-ground, even after the hand of man has effected great changes in its character; so much so, that a particular spot, where a pair of birds of this species had been accustomed to breed, was resorted to by them for that purpose long after it, and many acres round it, were planted with trees, and had become the centre of a flourishing wood."

END OF THE FIRST VOLUME. 


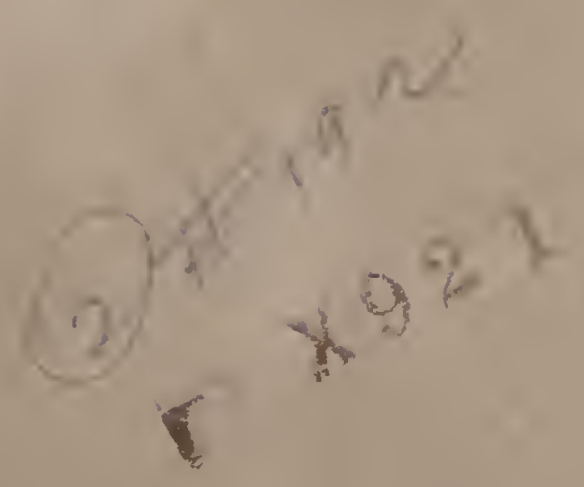





"10,

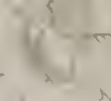

$x^{10}=0$

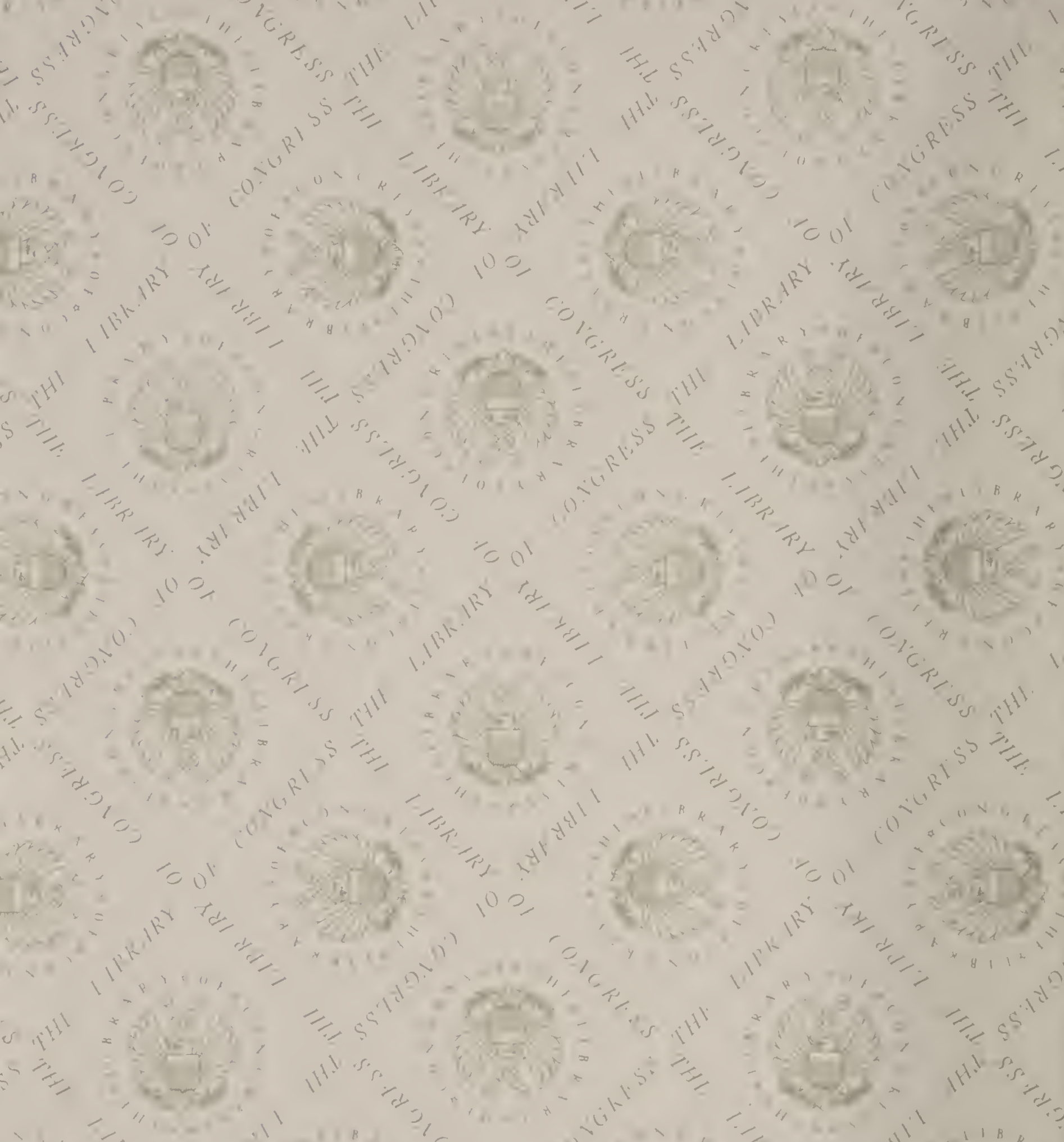

3
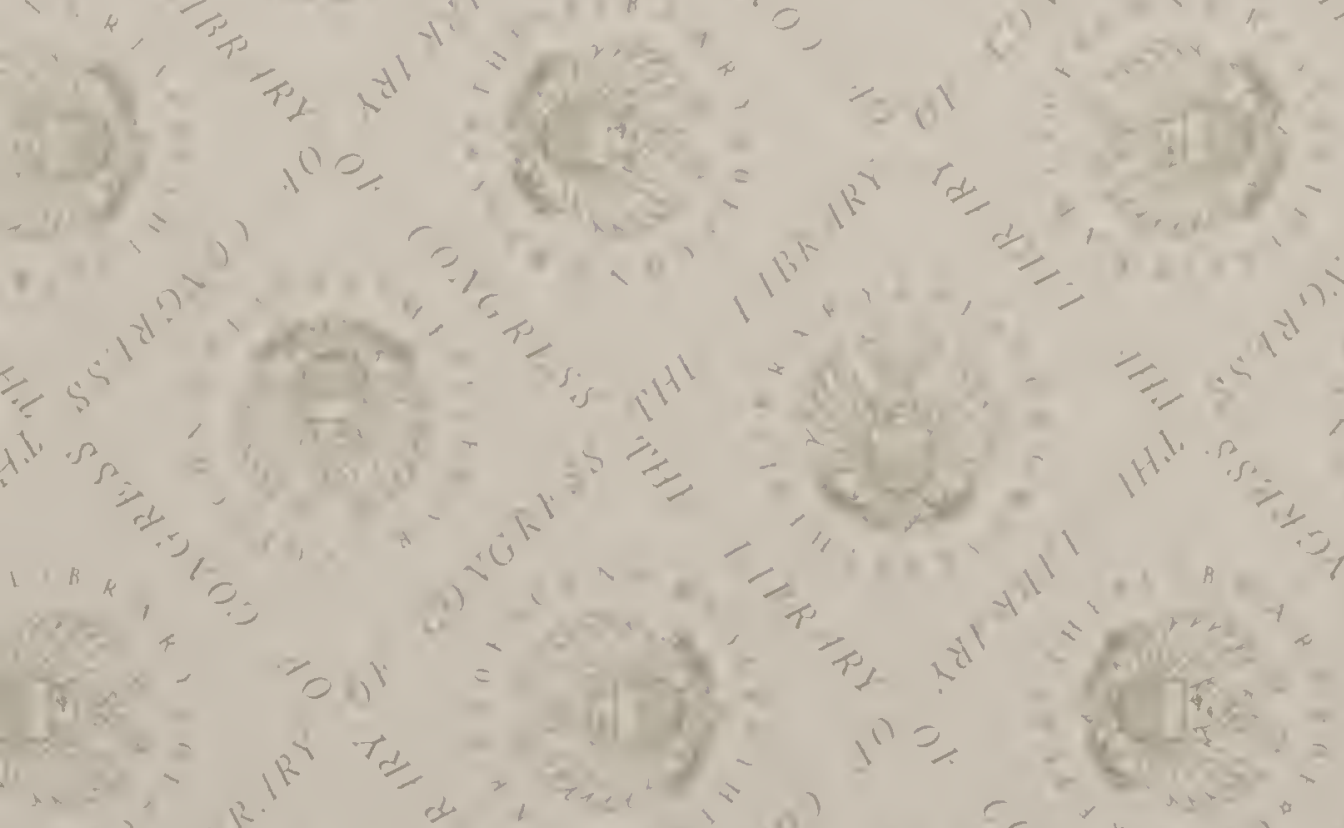

I9

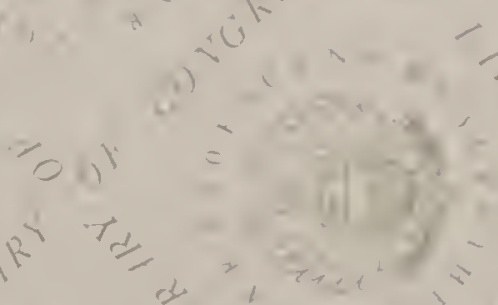
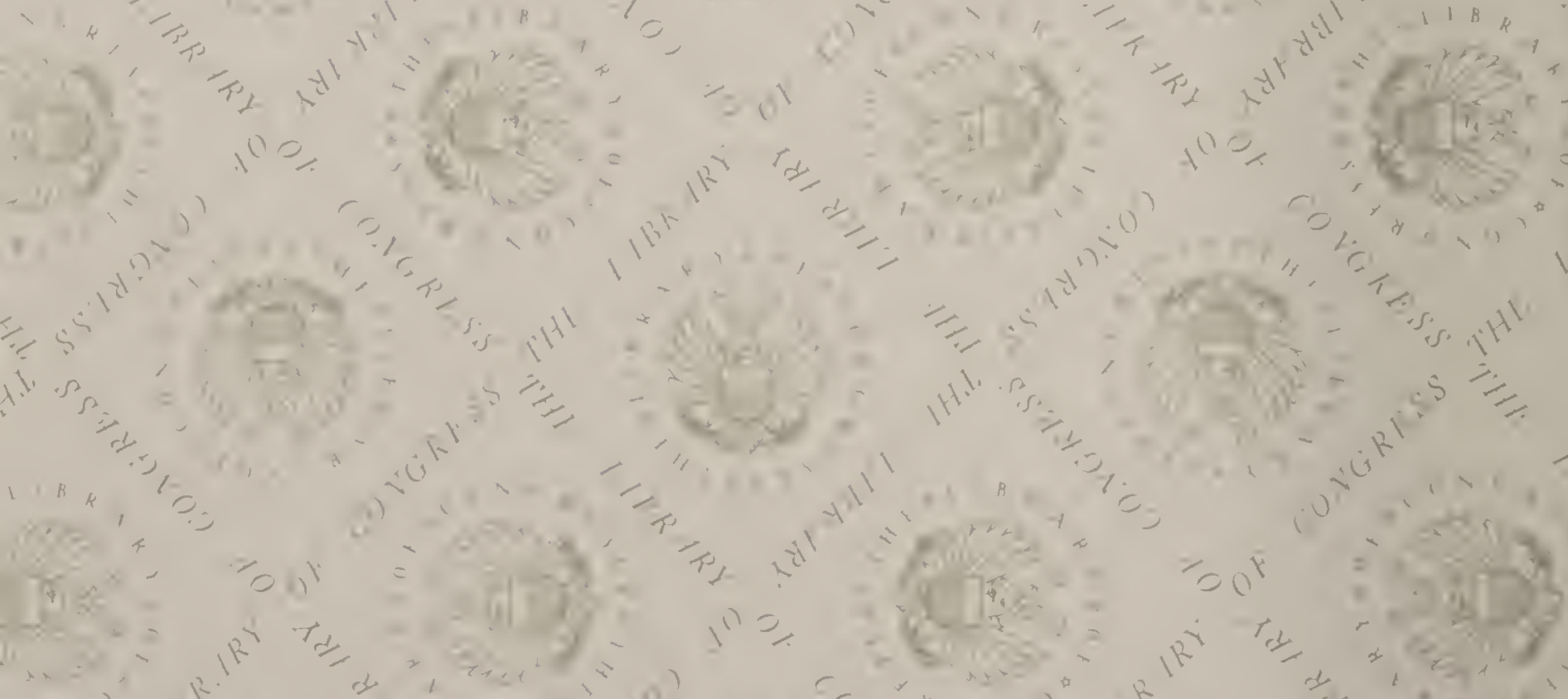


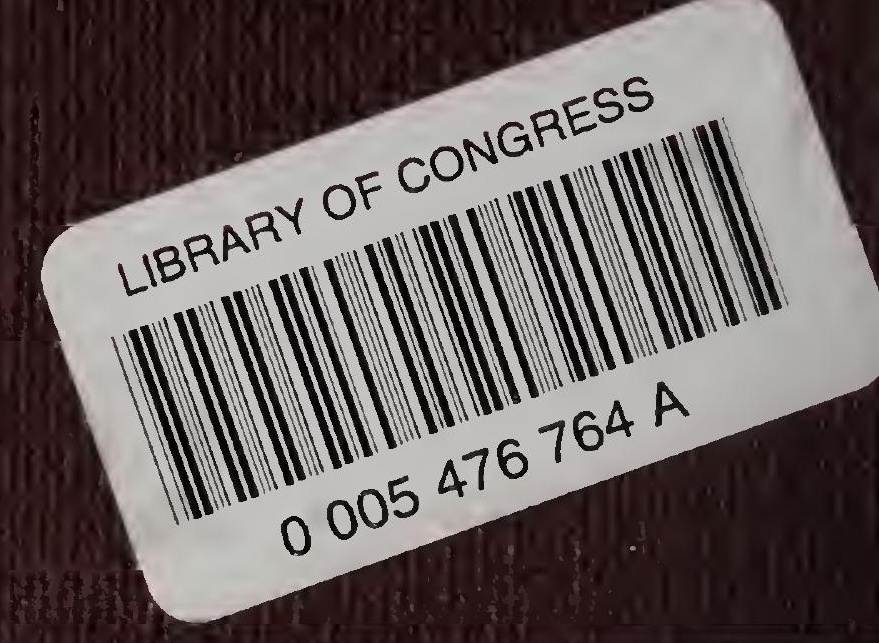

